\title{
Vegetation and functional diversity of sand dune habitats between and within different bioclimatic regions
}

\author{
Dissertation \\ for the award of the degree \\ "Doctor of Philosophy" Ph.D. \\ Division of Mathematics and Natural Sciences \\ of the Georg-August-Universität Göttingen \\ within the doctoral program Biology \\ of the Georg-August University School of Science (GAUSS) \\ submitted by
Parastoo Mahdavi
from Esfahan, Iran
}

Göttingen, 2017 
Thesis Committee

Prof. Dr. E. Bergmeier, Abt. Vegetationsanalyse \& Phytodiversität, Georg-August-Universität Göttingen

Prof. Dr. C. Leuschner, Abt. Ökologie \& Ökosystemforschung, Georg-August-Universität Göttingen

Members of the Examination Board

Reviewer: Prof. Dr. E. Bergmeier, Abt. Vegetationsanalyse \& Phytodiversität, Georg-AugustUniversität Göttingen

Second reviewer: Prof. Dr. C. Leuschner, Abt. Ökologie \& Ökosystemforschung, GeorgAugust-Universität Göttingen

Further members of the Examination Board:

Prof. Dr. H. Behling, Abt. Palynologie und Klimadynamik, Georg-August-Universität Göttingen

Prof. Dr. T. Friedl, Abt. Experimentelle Phykologie und Sammlung von Algenkulturen der Universität Göttingen (EPSAG), Georg-August-Universität Göttingen

PD. Dr. M. Waltert, Blumenbach Institute for Zoology and Anthropology, Conservation Biology/Workgroup on Endangered Species, Georg-August-Universität Göttingen

Prof. Dr. H. Kreft, Abt. Biodiversität, Makroökologie und Biogeographie, Georg-AugustUniversität Göttingen

Date of the oral examiniation: 26.4.2017 


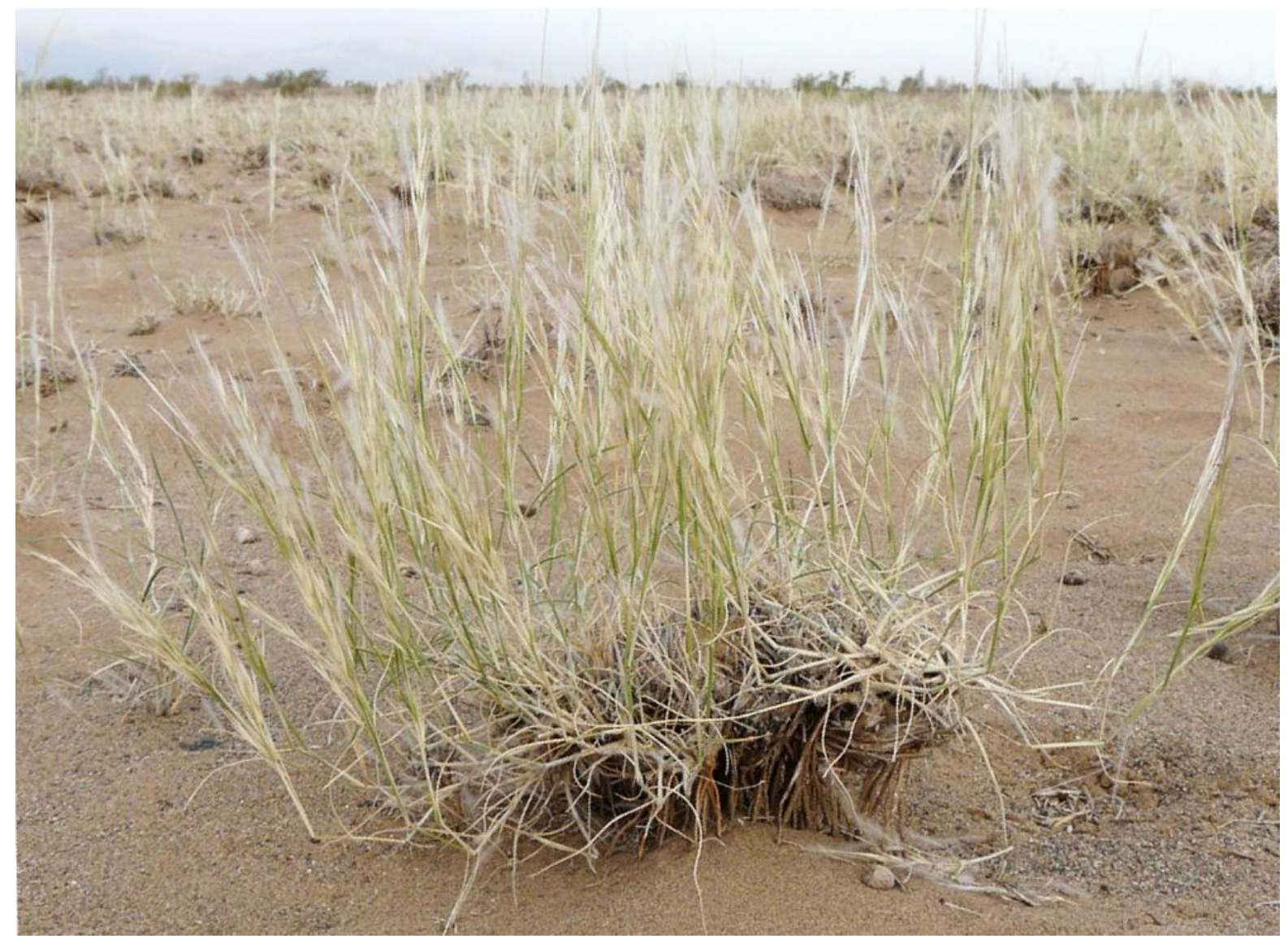

"It is not the strongest of the species that survive,

nor the most intelligent,

but the one most responsive to change."

Charles Darwin 


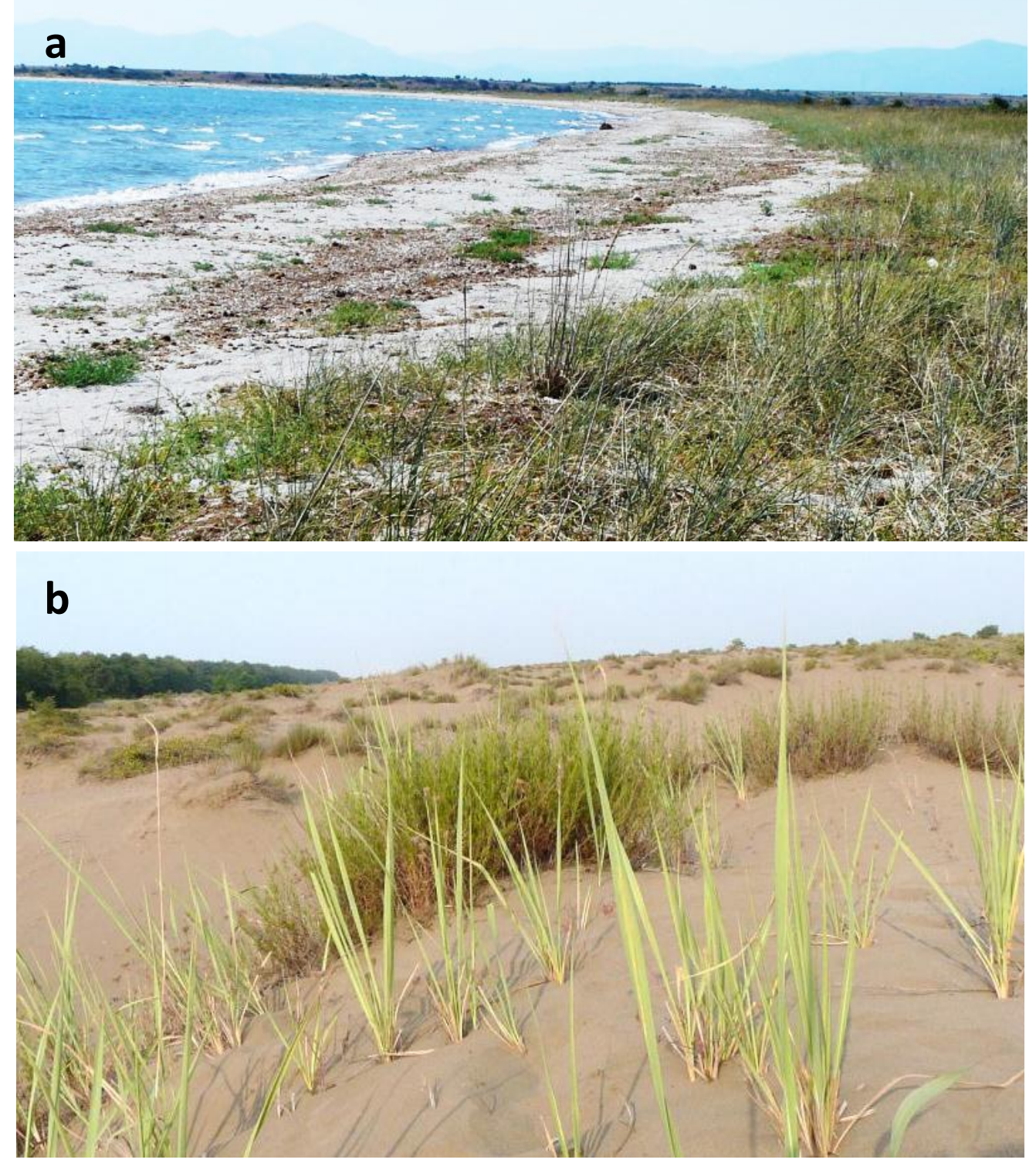

\section{C}

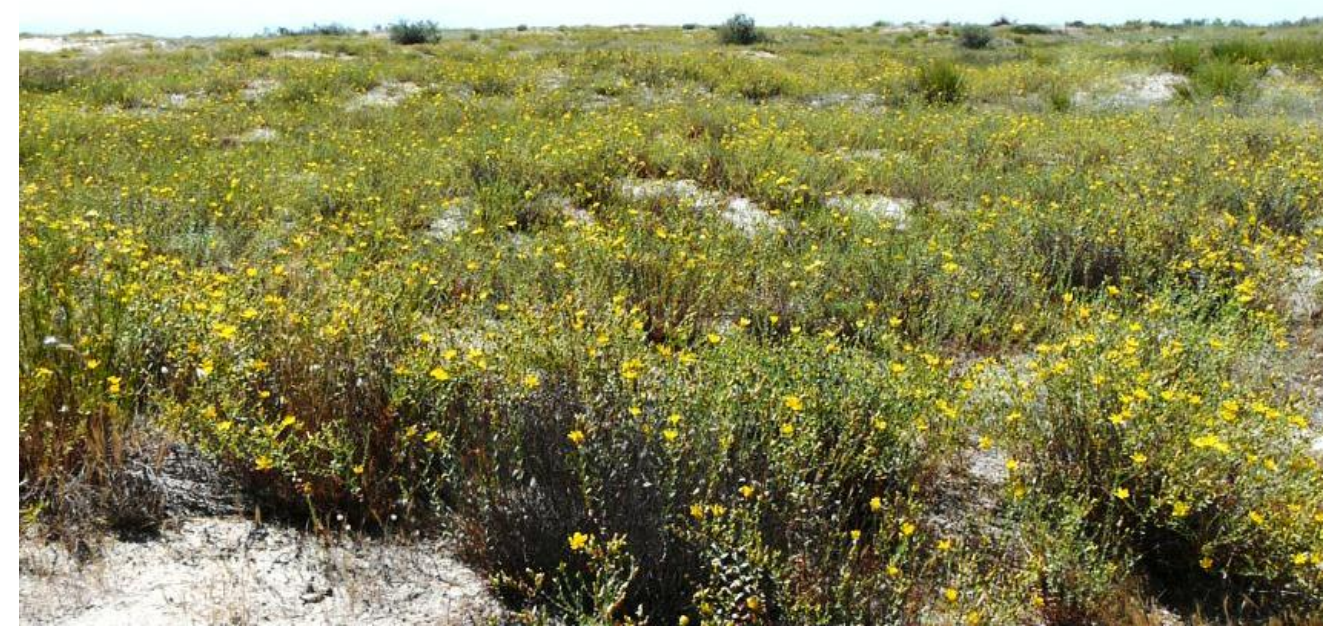




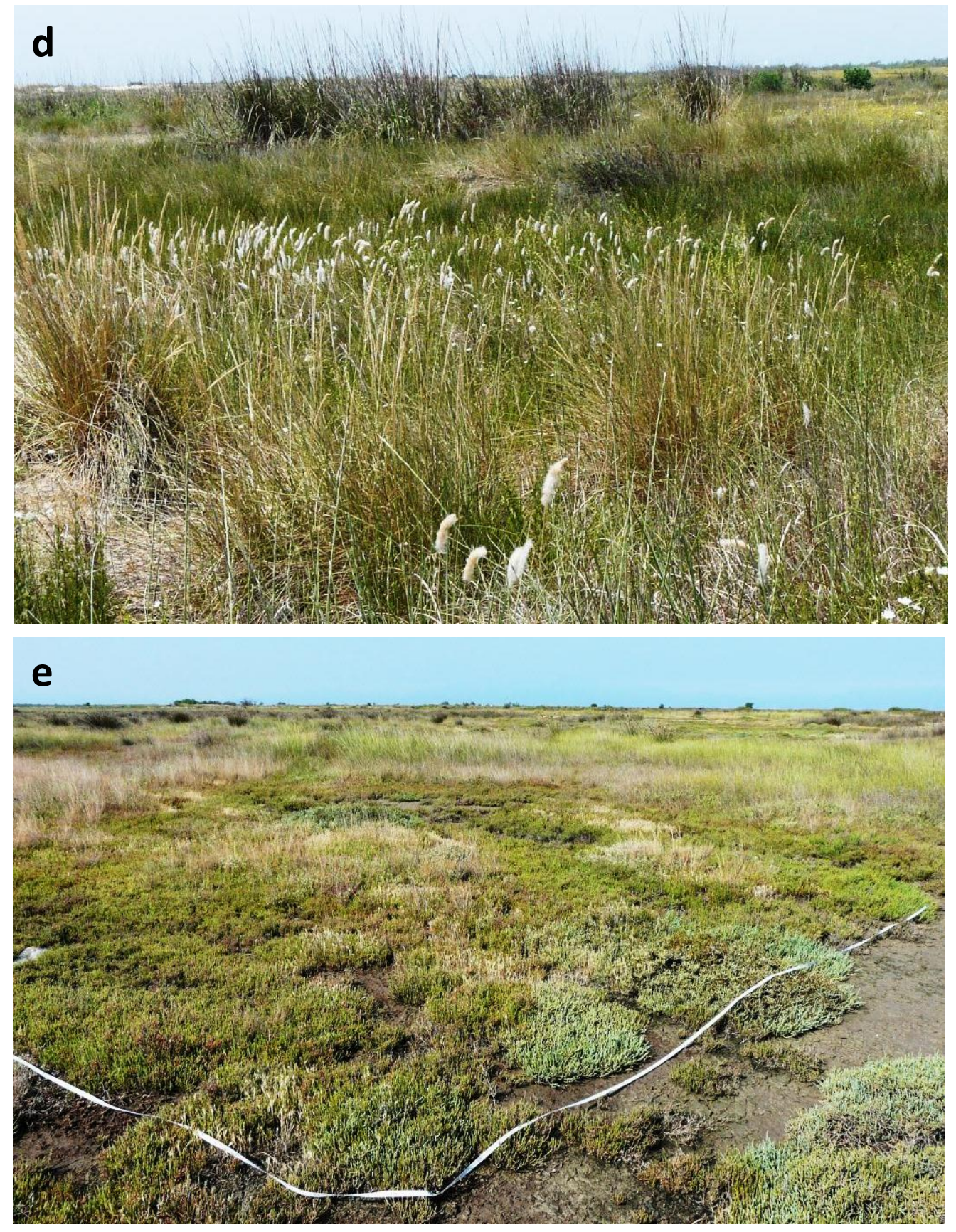

View of the main habitats occurring in sand ecosystems: a. driftline; b. mobile dune; c. stabilized dune; d. dune slack; e. salt marsh. 



\section{Contents}

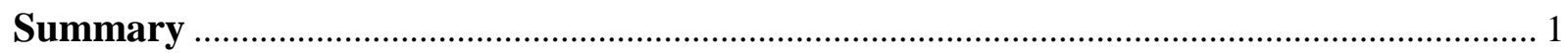

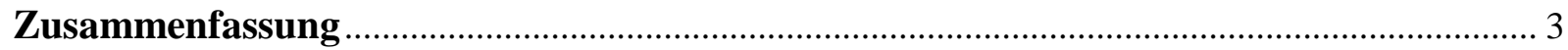

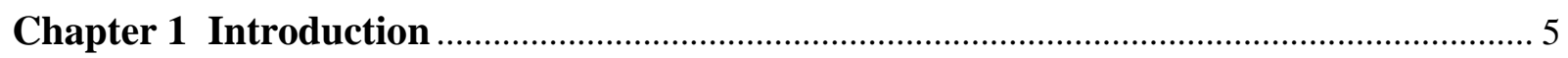

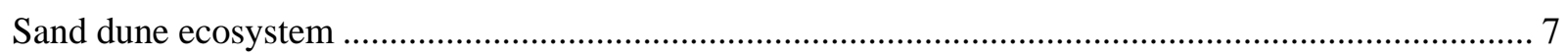

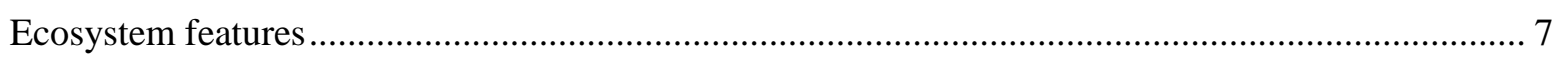

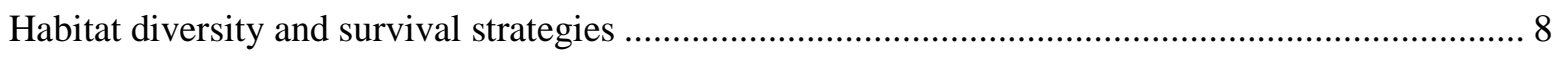

Adaptive traits of plants as a key to understanding ecosystem function .............................................. 11

Concept and definition of functional traits.............................................................................. 11

Ecological values of the functional approach............................................................................. 12

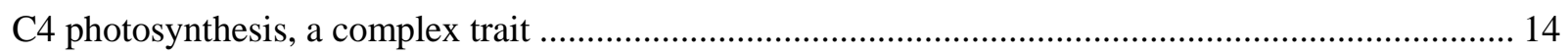

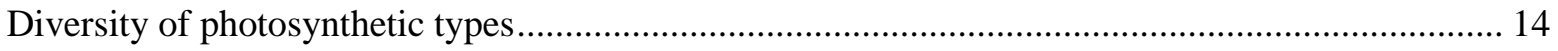

Evolutionary pressure

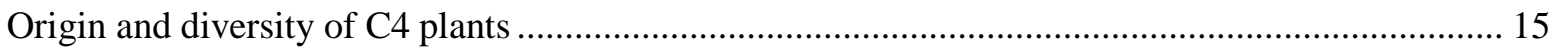

Study area

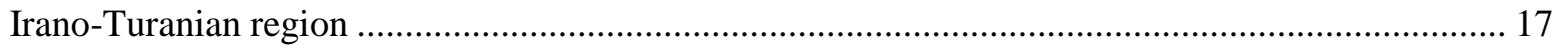

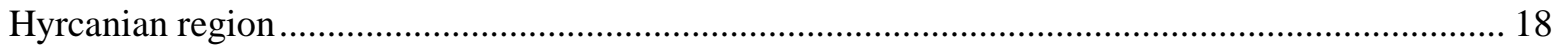

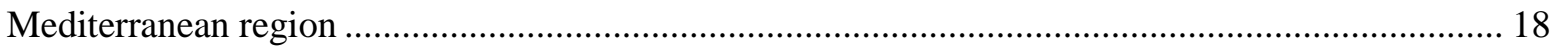

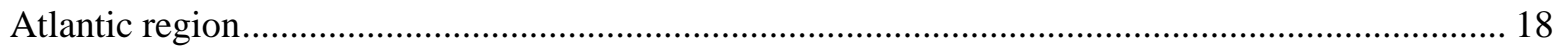

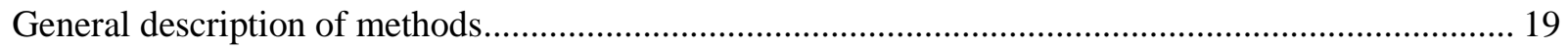

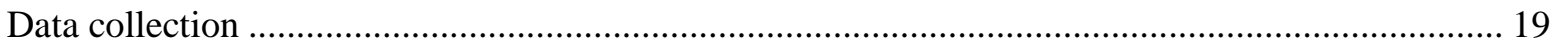

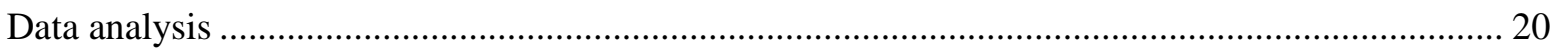

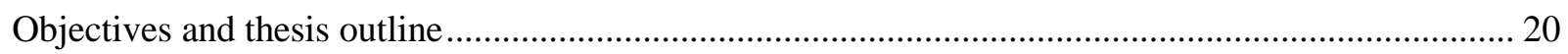

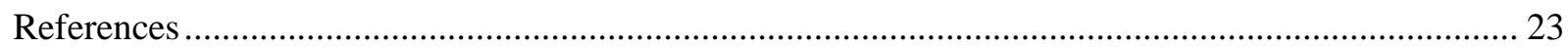

Chapter 2 Plant functional traits and diversity in sand dune ecosystems across different

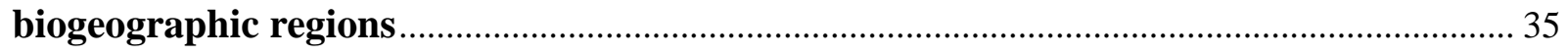

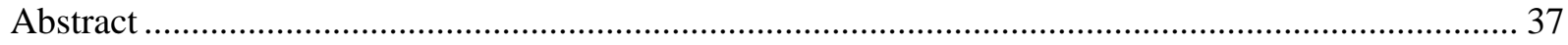

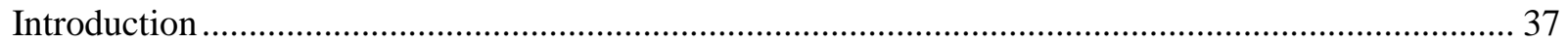

Study area

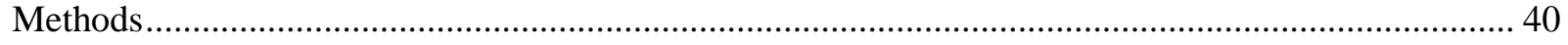

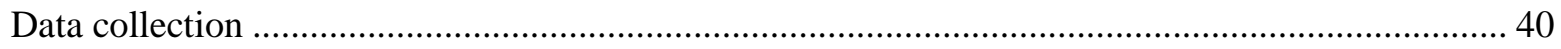




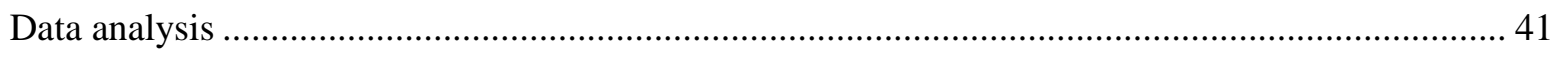

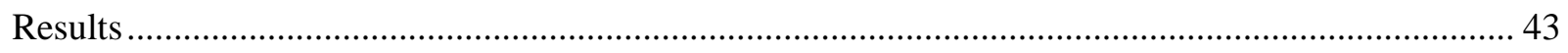

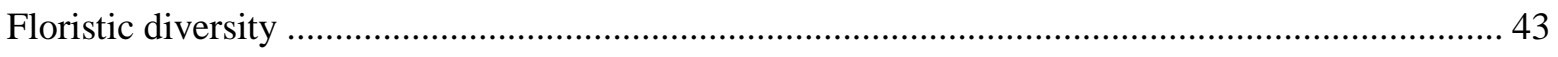

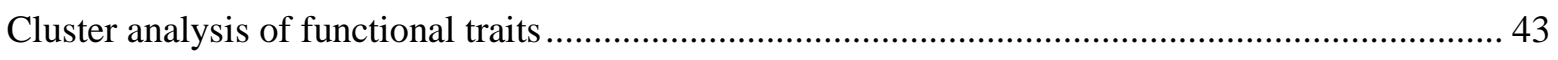

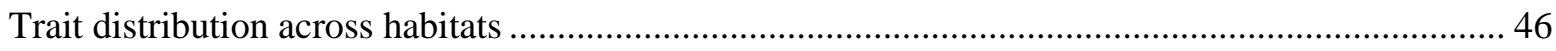

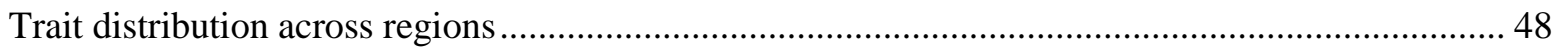

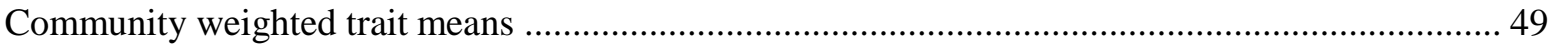

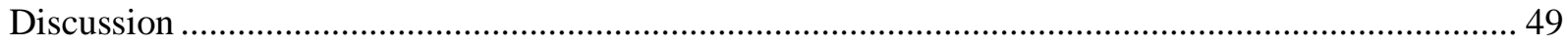

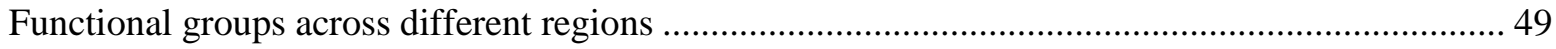

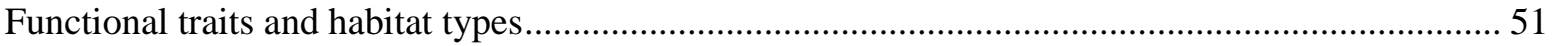

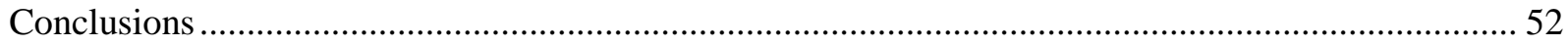

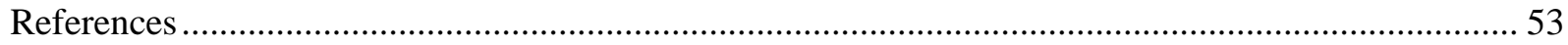

Chapter 3 Sand habitats across biogeographical regions at species, community and

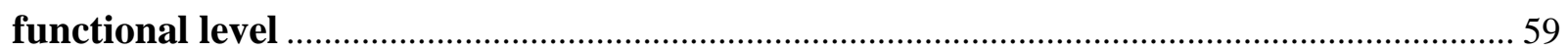

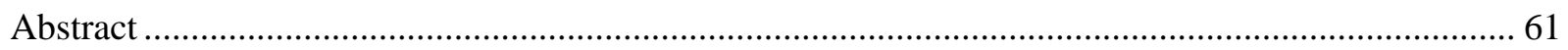

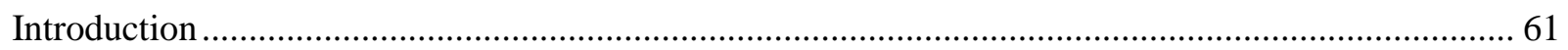

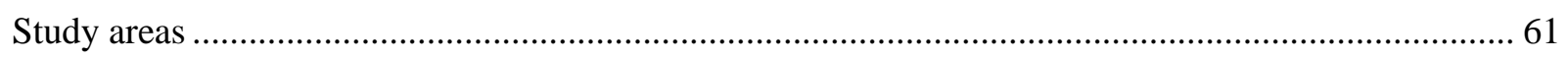

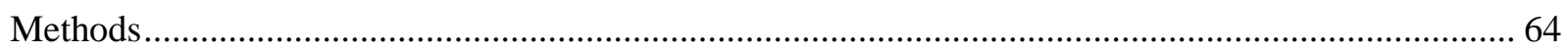

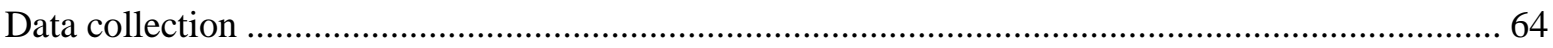

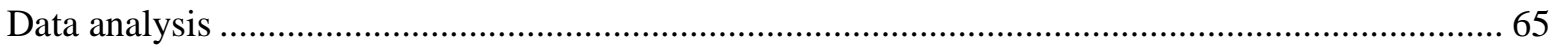

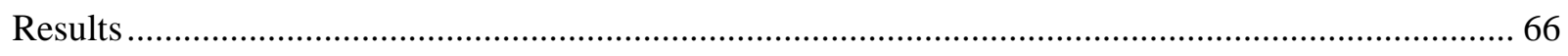

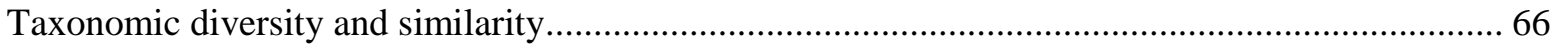

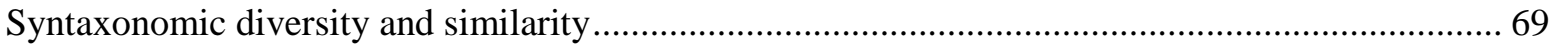

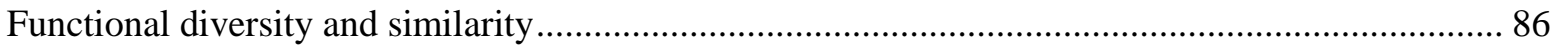

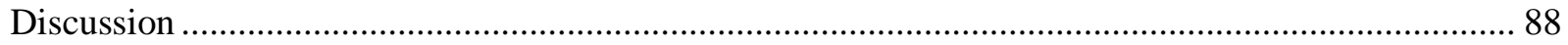

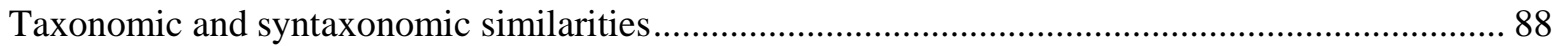

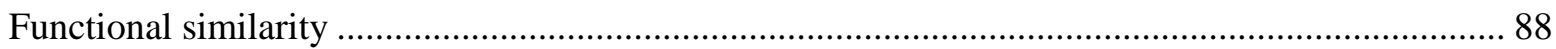

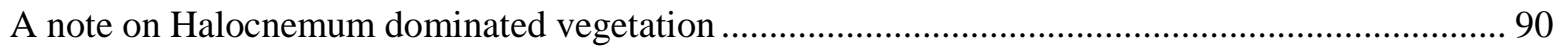

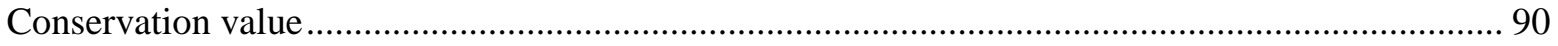

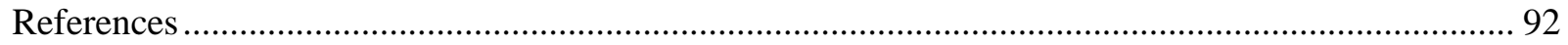

Chapter 4 Distribution of C4 plants in sand habitats of different regions ....................... 97

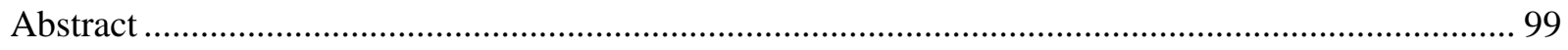

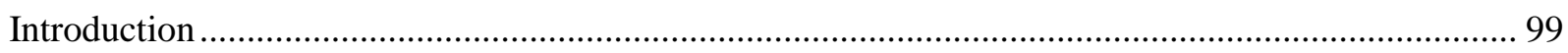




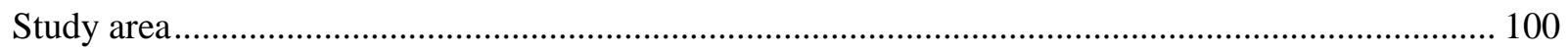

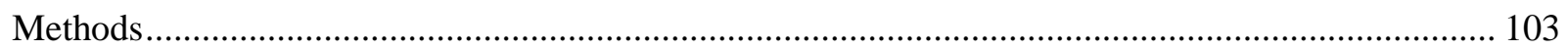

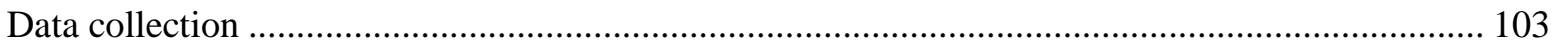

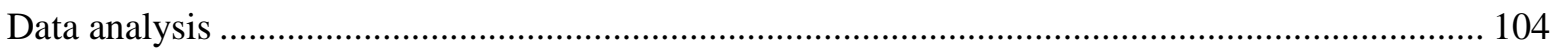

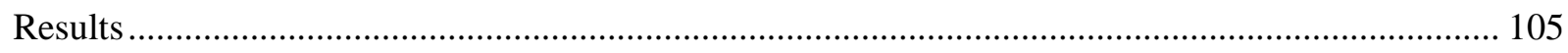

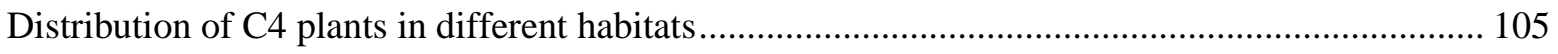

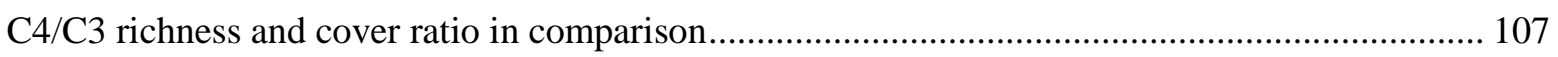

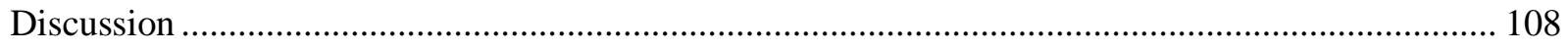

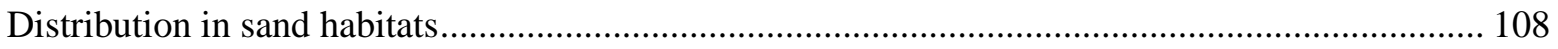

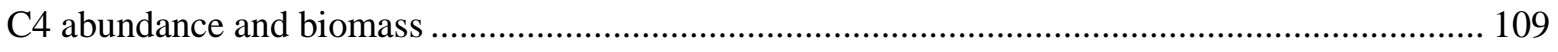

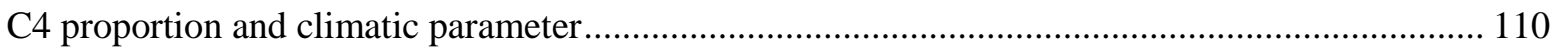

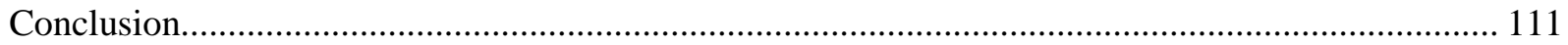

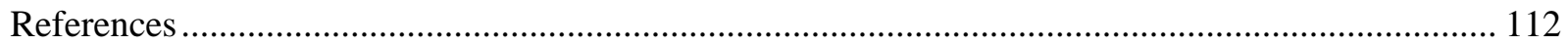

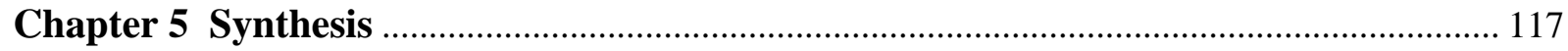

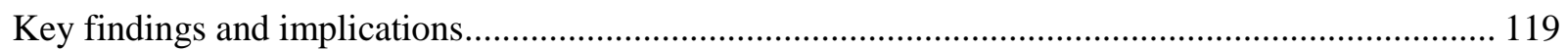

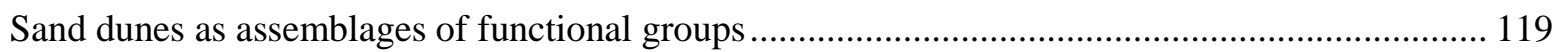

Is habitat similarity reflected in vegetation similarity across regions? ....................................... 120

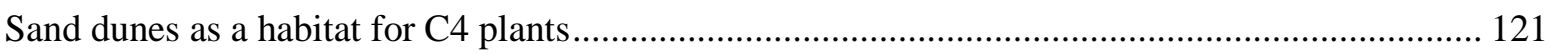

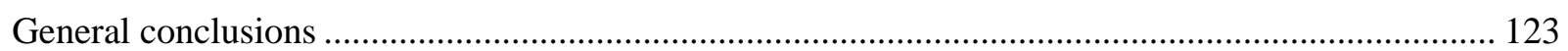

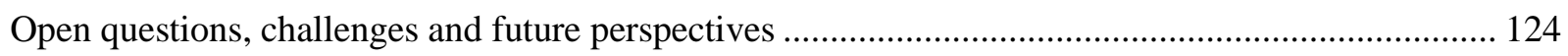

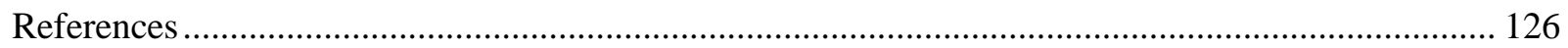

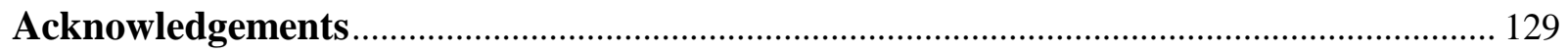

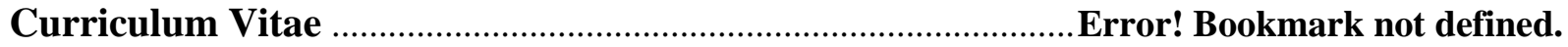

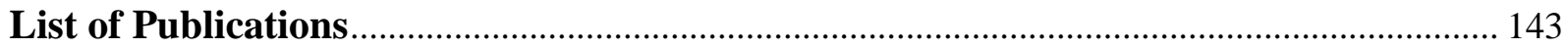

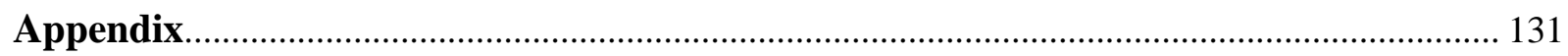

Appendix A The data sheet as used for the vegetation survey...................................................... 133

Appendix B Alphabetical list of species for plant functional groups resulted from cluster analysis.137

Appendix $\mathrm{C}$ List of distinguished syntaxa in the study areas......................................................... 135 



\section{List of Figures}

\section{Chapter 2}

Fig. 1 Location of the study areas in the three climatic regions...................................................... 40

Fig. 2 Functional groups of species in sand dune habitats based on their trait similarities, using hierarchical cluster analysis.

Fig. 3 Relation of habitats with functional groups (FG1-7) shown by DCA ordination of a species-plot matrix for each region.

Fig. 4 DCA ordination of the trait-plot matrix for the combined data of three regions.

\section{Chapter 3}

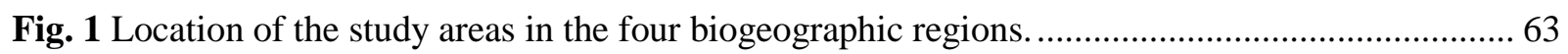

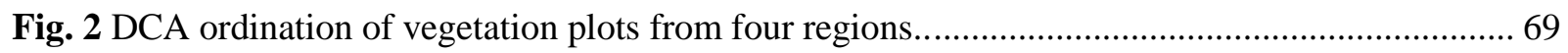

Fig. 3 Cumulative cover proportions (in \%) of functional groups in the vegetation classes of each

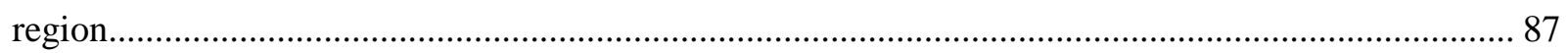

\section{Chapter 4}

Fig. 1 Overview of the investigated area in Iran and Greece. 



\section{List of tables}

\section{Chapter 2}

Table 1 List of plant functional traits and their attributes used in this study ..................................... 42

Table 2 Plant functional groups obtained from cluster analysis...................................................... 45

Table 3 Community weighted trait mean calculated for the five habitat types................................. 49

\section{Chapter 3}

Table 1 Bray-Curtis index of beta diversity for each habitat type over the four regions. 67

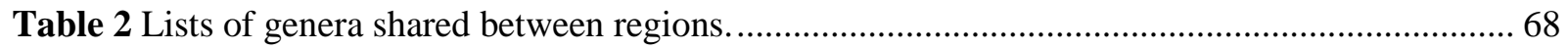

Table 3 Synoptic table of coastal vegetation in N Germany.......................................................... 70

Table 4 Synoptic table of coastal vegetation in NE Greece. .............................................................. 74

Table 5 Synoptic table of coastal vegetation in N Iran.................................................................... 78

Table 6 Synoptic table of sand dune vegetation in Central Iran........................................................ 81

Table 7 Syntaxonomic comparison of vegetation in the four regions................................................ 83

\section{Chapter 4}

Table 1 List of recorded C4 species in the three investigated areas............................................. 103

Table 2 Differences in climatic parameters between regions. ........................................................ 106

Table 3 Richness and cover ratio in sandy habitats of three study regions. ...................................... 107 



\section{Summary}

Use of plant functional types has a long tradition in ecology from the time that von Humboldt offered the first physiognomic classification of plants based on growth form. In recent years, the application of functional traits in ecological studies increased and a variety of new measuring and statistical methods were developed. Functional groups comprise species with similar traits and thus similar response to environmental pressures and similar effects on ecosystem processes. Therefore, it is expected that they are affected rather by niche similarities than by biogeographic regions. However, the feasibility and applicability of functional groups at global scale and across different regions is still an open question.

Sand ecosystems are stress-prone habitats with quite low number of species, characterized by long environmental gradients on relatively small area and high ecological and habitat diversity. Considering these facts, sand ecosystems are a suitable model for ecological research. Furthermore, despite increasing attention to functional traits, the knowledge on functional ecology of sand ecosystems is limited. This thesis contributes to fill the gap on functional ecology of sand dunes by defining clusterbased functional groups of species and functional composition of plant communities across different biogeographic regions. Further, the effect of habitat and climatic region on functional groups and the similarity of sand habitats at species, community and functional level were investigated. Finally, the distribution of photosynthesis types across different sand habitats was examined. To achieve the targets, various sand habitat types (drift lines, mobile dunes, stabilized dunes, salt marshes, semi-wet sand and sandy disturbed habitats) across different climatic regions (Atlantic, Mediterranean, Hyrcanian and Irano-Turanian) were studied.

We found that sand ecosystems can be defined by sets of functional groups despite their regional climatic and species pool differences. It provides further support to the idea that classification of functional traits should be applicable to other regions. Based on our trait classification, sand dune ecosystems can be described with three main adaptive strategies among perennials and four strategy types in annuals. Ordination analysis of traits also shows that functional traits of the same habitat assembled together irrespective of their regions. This indicates that plant traits in sand ecosystems are grouped reflecting habitat affiliation rather than regional belonging.

Furthermore, we investigate the similarity of sand habitats at species, community and functional level. We found by changing the focus from species to community and to functional level, sand habitats of the same kind represent more similarity across regions. The highest habitat similarity was observed at functional level and the lowest at taxonomic level. The vegetation of all habitats at functional level is considered as azonal vegetation and independent from the climatic region. We found out that the more stress-prone a habitat, the more is its vegetation habitat-related and independent from the region. We 
also tested the functional composition of the vegetation to compare plant communities across different regions. This is useful to understand and describe plant communities as trait groups reflect habitat and ecosystem conditions. However, species composition of habitats shows more region-related patterns. In this case, biogeographical distance prevails over environmental similarity.

We found C4 plants to have notable contribution to the vegetation cover in salt marshes, mobile dunes and disturbed sandy grounds despite their low number of species. Our results reveal that $\mathrm{C} 4$ species contribute most notably to the vegetation cover and less to the richness in comparison to $\mathrm{C} 3$ species. It indicates that environmental conditions (at least in some sand habitats) favor $\mathrm{C} 4$ plants to form dominant vegetation. Intensive light, high summer temperature and dryness are features of sand ecosystems which make $\mathrm{C} 4$ photosynthesis more efficient than the $\mathrm{C} 3$ pathway. We observed a general increasing trend in richness and cover of $\mathrm{C} 4$ species with increase of aridity. The highest proportion of C4 species occurred in C Iran, the driest and warmest study region. 


\section{Zusammenfassung}

Die Verwendung von funktionellen Gruppen bei Pflanzen hat eine lange Tradition in der Ökologie, spätestens seit von Humboldt die erste physiognomische Klassifikation auf der Grundlage von Wuchsformen zusammenstellte. In den letzten Jahren wurden sie zunehmend benutzt, wobei eine Vielzahl neuer Meßverfahren und statistischer Methoden entwickelt wurde. Funktionelle Gruppen setzen sich aus Arten mit ähnlichen Eigenschaften zusammen und weisen demnach ähnliche ökologische Anpassungen auf und haben gemeinsame Auswirkungen auf Ökosystemprozesse. Deshalb kann man erwarten, daß ihre Zusammensetzung eher durch eine Ähnlichkeit des Standorts, als durch biogeographische Regionen geprägt wird. Vergleichbarkeit und Anwendbarkeit funktioneller Gruppen auf überregionaler oder gar globaler Ebene wurden aber bisher kaum untersucht.

Sandökosysteme sind von Streß geprägt und enthalten oft nur wenige daran angepaßte Arten. Dennoch treten lange ökologische Gradienten auf kleiner Fläche auf, die zu relativ hoher ökologischer und standörtlicher Vielfalt führen. Dies macht Sandökosysteme zu geeigneten Modellen für ökologische Forschungen. Des weiteren ist, trotz steigendem Interesse an funktionellen Gruppen, das Wissen um die funktionelle Ökologie von Sandökosystemen noch beschränkt. Die vorliegende Arbeit füllt zahlreiche Wissenslücken zur funktionellen Ökologie von Sandökosystemen. So werden funktionelle Artengruppen über Cluster-Analysen definiert und die funktionelle Zusammensetzung für Pflanzengesellschaften über mehrere biogeographische Regionen hinweg beschrieben. Weiterhin wird der Einfluß von Lebensraum und Klimaregion auf funktionelle Gruppen untersucht sowie die Ähnlichkeit von Sandlebensräumen jeweils für die Ebene der Pflanzenarten, der Pflanzengesellschaften und der funktionellen Gruppen untersucht. Schlußendlich wird auch die Verteilung von Photosynthesetypen in unterschiedlichen Sandlebensräumen dargestellt und diskutiert. Um die genannten Zielstellungen zu bearbeiten wurden verschiedene Lebensräume (Spülsäume, Wanderdünen, stabilisierte Dünenbereiche, Salzmarschen, (teil)feuchte Sandbereiche und gestörte Sandhabitate) in unterschiedlichen Klimaregionen studiert (Atlantische, Mediterrane, Hyrkanische und IranoTuranische Region).

Wir zeigen, daß Sandökosysteme trotz großer Unterschiede bei regionalem Klima und Artenzusammensetzung durch Zusammenstellungen von funktionellen Gruppen definiert werden können. Dies untermauert, daß sich die Klassifikationen funktioneller Merkmale auf andere Regionen übertragen lassen. Durch Klassifikation funktioneller Merkmale können Sandökosysteme auf Grundlage von drei Anpassungsstrategien ausdauernder Arten und vier Strategietypen der Annuellen beschrieben werden. Ordinationsanalysen zeigen, daß sich funktionelle Merkmale unabhängig von der 
Region gemeinsam anordnen. Das macht deutlich, daß Pflanzenmerkmale in Sandökosystemen eher eine Bindung an den Lebensraum als einen regionalen Bezug aufweisen.

Weiterhin verglichen wir Sandhabitate auf den Ebenen von Pflanzenarten, Pflanzengesellschaften und funktionellen Gruppen. Es ist erkennbar, daß bei einer Fokussierung auf Arten, Gesellschaften und zuletzt funktionelle Gruppen, die Ähnlichkeit zwischen gleichartigen Habitaten zunimmt. Die höchste Ähnlichkeit wurde auf funktioneller Ebene ermittelt, die niedrigste auf taxonomischer Ebene. Die Vegetation aller untersuchten Habitate auf der funktionellen Ebene, kann als azonal und damit unabhängig von der Klimaregion angesehen werden. Wir fanden zudem heraus, daß stärkere Stressabhängigkeit der Vegetation, eine stärkere Bindung an den Lebensraum als an die Klimaregion bedingt. Wir testeten auch die funktionelle Zusammensetzung der Vegetation um unterschiedliche Regionen zu vergleichen. Dies ist nützlich um Pflanzengesellschaften ökologisch zu verstehen und zu beschreiben, da Merkmalsgruppen Habitat- und Ökosystembedingungen widerspiegeln. Allerdings weist die Artenzusammensetzung der Lebensräume in diesem Teil regionale Muster auf und es überwiegt die biogeographische Distanz im Gegensatz zu ökologischer Ähnlichkeit.

Wir fanden zudem heraus, daß C4 Pflanzen einen nennenswerten Beitrag auf die Vegetationsbedeckung von Salzmarschen, Wanderdünen und gestörten Sandbereichen haben, obwohl nur wenige solcher Arten auftreten. Unsere Ergebnisse zeigen, daß C4 Arten am stärksten die Bedeckung und beeinflussen und weniger die Artenvielfalt im Vergleich zu C3 Pflanzen. Dies zeigt, daß zumindest in einigen Sandlebensräumen C4-Pflanzen gefördert werden und dominieren können. Hohe Lichtintensität, hohe Sommertemperaturen und ausgeprägte Trockenheit sind typische Eigenschaften von Sandökosystemen, die C4-Photosynthese gegenüber dem C3-Weg effizienter machen. Wir konnten eine generelle Zunahme von Artenreichtum und Bedeckung von C4 Pflanzen mit zunehmender Trockenheit feststellen. Der höchste Anteil von C4 Arten trat im Inland von Iran auf, der trockendsten und heißesten Region. 


\section{Chapter 1}

\section{Introduction}





\section{Sand dune ecosystem}

\section{Ecosystem features}

Sand dunes are sedimentary deposits occurring in different shapes and size. They are formed by interactions of wind and water erosion. Common in many parts of the world, they are found in coastal areas, inlands and along sandy river beds and valleys. Sediments in coastal dunes originate from glacial ice shelves and at present from cliff erosion, river discharges and input from tides and storm. In dry regions, the weathering of sand stones and rocks is the main source of sand. In rivers, water carries sands and deposits them on banks through overflow events (Maun 2009). In all cases, wind plays an important role in moving sands and shaping them to dunes. Vegetation also influences dune morphology through local changes in wind velocity and direction. It plays an important role in fixing the windblown deposit of sand (Danin 1996). Presence of particular plant communities in different zones are crucial for preserving the natural dune morphology (Acosta et al. 2007).

Another feature of sand dunes is symbiotic association of mycorrhizal fungi with the roots of higher plants. Mycorrhizal fungi have a vital role in establishment, survival and growth of plants. They increase the water and nutrient supply for the plants and in return they take organic compounds from the plants. The most common and widespread types of mycorrhizal fungi are arbuscular mycorrhizas. Mycorrhizal fungi strongly enhance the aggregation of sand particles. Similarly, microbiotic crust on the sand surface plays an important role in sand fixation. Disturbances can destroy the hyphal networks and thus the fungal communities (Danin 1996, Maun 2009).

Inland and coastal dunes are similar in main environmental pressures, physical structure, physiognomy, and plant strategies. In addition to different species composition, there are three main differences between these two types (Danin 1996): species of coastal sand dunes have to withstand salt spray and inundation by sea water in addition to sand burial. Climax vegetation in many coastal dune systems consists of phanerophytes whereas in inland dunes is mainly of chamaephytes. There is a persistent supply of organic matters from the sea in coastal dunes but such resources do not exist in desert dunes. Despite their variety in shape and form, all sand ecosystems are exposed to sand burial, salinity, aridity, lack of soil and nutrients and high wind velocity.

Although, the number of species in sand habitats is quite low due to harsh environmental conditions, sand ecosystems represent high ecological and biological diversity to both flora and fauna. Following the EU Habitats Directive (European Commission 2003) and EUNIS habitats (Schaminée et al. 2001) more than 10 habitat types are listed under coastal sand dunes and more than 5 habitat types for salt marshes and salt meadows of Europe. Sand dune ecosystems are a suitable model for ecological 
Chapter 1: Introduction |

research because of their long environmental gradient, habitat diversity in relatively small areas and their low number of species in comparison to other ecosystems.

They provide important services such as sediment storage and transport, protection against wind erosion, waves and sea-level rise, water filtration and storage, carbon sequestration, provision of food, cultural services and they are essential breeding and nesting areas for wildlife (Defeo et al. 2009; Everard et al. 2010; Barbier et al. 2011). Many of these services are also applicable for inland dunes.

Sand dunes are one of the most endangered ecosystems worldwide which are in threat of habitat loss, fragmentation and biodiversity loss (flora and fauna) under high pressure of human activities (EEA 2008). Urbanization, agriculture, trampling and touristic development are the most important threats (Buffa et al. 2012; Pintó et al. 2014). Off-road vehicles which are commonly used in sandy area cause high ecological impact on the ecosystem. They disturb not only the physical features of the sand surface and stability of sand dunes but also destroy the vegetation and kill animals inhabiting such habitats (Defeo et al. 2009). Beach cleaning heavily affects the vegetation as it removes seedlings and young plants and increases sand erosion. Alteration of dune morphology through disturbances and human activities is highly correlated to changes in coastal vegetation zonation and loss of habitats (Acosta et al. 2007). Comparison of real vegetation with potential natural vegetation in Central Italy shows that only in few sites vegetation zones are relatively well-preserved (Acosta et al. 2004). Vegetation models predict that mobile and fixed dunes of Italy are under high pressure and will disappear without proper conservation plans only due to climate changes (Prisco et al. 2013). However, in many national Red Lists these habitats and their plant species are not well represented. Precise assessment of the dune systems is suggested by some researchers for conservation purposes (e.g. Pintó et al. 2014). Restoration of these vulnerable habitats and preservation of the remaining sites are important issues in order to sustain the sand ecosystem (Martinez et al. 2013).

\section{Habitat diversity and survival strategies}

Sand dunes are characterized by strong environmental gradients in a relatively small area. This creates a zonation and a wide range of habitats from dry shifting dunes to semi-wet dune slacks and saltmarshes (Doing 1985), mainly differentiated by salinity and drought gradient. Habitat heterogeneity results in vegetation diversity (Redžić 2007). Each zone provides specific environmental conditions, inhabited and shaped by particular plant communities.

Plant communities in sand dunes and saltmarshes have been documented for many regions especially in Europe (Mucina et al. 2016). However, further research is required in countries like Iran and Greece. In the following sections the ecological conditions determining plant species composition in each 
habitat zone and adaptive mechanisms of plants are described. Syntaxonomic details are provided in Chapter 3.

\section{Drift lines}

This habitat is characterized by narrow linear zone which occurs just above the normal upper tidal limits along the sea shores. They may be rich in pebbles and shingle and have always high amounts of organic matter (Sykora et al. 2003, European Commission 2013). Inundations and frequent disturbances through high tides and storms are common features of this zone which is not suitable for survival of most perennial plants (Grime 2006). Drift lines are sparsely inhabited by annual nitrophilous plants resistant to high salt concentration and frequent disturbances. Few species can complete their life cycle under such unfavorable conditions e.g. Cakile maritima, Atriplex laciniata, Xanthium strumarium and Salsola kali. However, the habitat shows the highest proportion of endangered species (Acosta et al. 2009) and properly listed as endangered habitat for Germany (Rennwald 2000) which is also the case for many regions.

Plants of drift line share common traits as adaptations to harsh conditions including short life cycle, good dispersal ability, seed dormancy and large seed size. Although, rate of mortality is usually high and plants' population vary year to year, but still some plants could complete their life cycle in short period within disturbances (Maun 2009). Species of Cakile have dimorphic two-segmented silique with an abscission layer between upper and lower part at maturity. They can float in water because of hard, corky and indehiscent pericarp. The upper part breaks off but the lower part remains on the parent plant. The upper fruit segment with thicker shell is well adapted to water dispersal (Barbour 1972). The larger seed size enable the upper fruit to grow under sand burial (Maun 2009).

\section{Mobile dunes}

Shifting dunes occur above the tidal limits and are characterized by sand accumulation and deflation. Sand burial and strong winds plays an important role in shaping the vegetation. In this zone disturbance is lower but wind velocity is higher. Sand accretion (to a certain extent) stimulates the growth of specific plants of mobile dunes, such as Ammophila arenaria, but also affects the composition and density of vegetation by reducing and eliminating species intolerant to sand burial (Maun 1998). Some species of this habitat are able to withstand sand burial as they can grow upwards rapidly and produce adventitious roots from the nodes of shoots (Fahn 1992). Another group can tolerate removal of sand from around the root by developing deep roots. Both horizontal and vertical root systems are common among plants on shifting dunes. Buds of these species are protected in the ground during the cold winter. Fragmentation of rhizomes and stolons facilitates dispersal and thus helps to establish new populations and colonies on bare sands (Maun 2009). 
Chapter 1: Introduction |

\section{Dune slacks}

They are depressions between dune hills where the water table is at or just below the sand surface. They are maintained by precipitation and ground water. Seasonal fluctuation of the water table is a feature of dune slacks. They are less exposed to erosion because of reduced wind velocity and soil moisture. There are different types of slack (from dry to flooded ones) depending on hydrological conditions. Water abstraction and drainage are threats to this habitat (Houston 2008). Compared to surrounding shifting dunes, they usually have higher species richness and/or biomass (Littmann \& Veste 2005).

\section{Stabilized dunes}

Grey dunes or stabilized dunes are further developed dunes occupying the landward zone behind the mobile dunes. They are more stable and sand movement is not a limiting factor. Drought stress is the main environmental factor affecting the vegetation. Provoost et al. 2004 found that the surface temperature of stabilized dunes in Belgium reaches above $50^{\circ} \mathrm{C}$. However, temperature declines rapidly below the sand surface. In depth of $5 \mathrm{~cm}$ from sand surface, temperature can drop about $10^{\circ}$ (Maun 2009). Due to the more stable soil conditions, vegetation is denser compared to seaward zones.

\section{Salt marshes}

Salt marshes are permanently or temporarily wet habitats that may be associated with tidal flats, salt pans or salt lakes. They are common on both coastal and desert sand systems. Salt marshes accumulate organic matter and are temporarily inundated by salty or brackish water. High evaporation causes salt enrichment in both inland and coastal salt marshes (European Commission 2013). This highly stressful environment is generally species poor and its vegetation is sparse to rather close. Salinity gradients, flooding frequency and duration, soil texture and amounts of organic matter determine vegetation structure and productivity of the habitat (Pennings \& Callaway 1992; Pennings \& Bertness 2001; Mucina \& O'Callaghan 2003). The vegetation is characterized mainly by succulent Chenopodiaceae such as Sarcocornia fruticosa, Arthrocnemum macrostachyum, Halocnemum strobilaceum and Salicornia spp.

Halophytes are differing in their tolerance to the concentration of salt. Salt tolerance often depends on various physiological and anatomical adaptations. Species show various degrees of succulency and usually possess a well-developed water storage tissue. Some are aphyllous or have small scale-like leaves while others have small thick leaves. Many coastal halophytes are densely covered by hairs, whereas inland halophytes are mainly glabrous and covered by a wax layer (Fahn 1992). Halophytes have different mechanism to achieve osmotic adjustment, including ion accumulation, synthesis or 
accumulation of organic compounds and water loss (Shannon 1997; Khan \& Gul 2002). Salt exclusion by roots is the most common way for avoiding salt. Some halophytes are able to excrete salt to leaf surface through their salt glands (e.g. Tamarix and Aeluropus) or accumulate it in salt bladders (e.g. Atriplex). Salt bladders are modified epidermal hairs that usually consist of two cells, stalk cell and bladder cell, that accumulate salt to prevent high salinity in mesophyll cells. Some plants shed leaves with high salt concentrations. Seeds of some species like Arthrocnemum macrostachyum, Cressa cretica, Suaeda fruticosa and Aeluropus lagopoides remain dormant at high salinity but germinate when return to distilled water (Khan \& Gul 2002).

\section{Adaptive traits of plants as a key to understanding ecosystem function}

As obtained from the last section, Environmental conditions and habitat characteristics act as a filter for species establishment and hence are important in shaping the vegetation. Adaptive strategies of plants have evolved under extreme conditions and are reflected in traits of plants. Therefore, plant traits can be used to find out about the vegetation dynamic and function of an ecosystem. The following sections describe functional traits and their importance in ecological studies.

\section{Concept and definition of functional traits}

Functional traits are characteristics of an organism which reveal function of that organism (Violle et al. 2007; de Bello et al. 2010). In plants, they consist of vegetative (whole-plant, leaf, stem and root traits), regenerative and ecophysiological traits which reflect adaptations to the environment (Cornelissen et al. 2003). Traits which can be measured relatively easily and quickly are so called 'soft traits' in contrast to 'hard traits' which may be more accurate indicators but are difficult or expensive to measure (Hodgson et al. 1999).

Plant functional traits such as life forms (Raunkiaer 1934) have been frequently used in ecological studies for a long time. However, in recent years, there is an increasing interest in using functional approaches to deal with different aspects of ecosystems and a variety of new methods have been developed and applied. Functional traits specifically allow simplifying and generalizing the ecosystem to a limited number of functional groups instead of dealing with large numbers of species (Gitay and Noble 1997).

Functional groups are species which respond similarly to environmental pressures or have similar effects on ecosystem processes and thus they can be divided to effect and response groups (Gitay and Noble 1997, Harrington et al. 2010). They can be identified as clusters through multivariate analysis of 
Chapter 1: Introduction |

traits, without a priori classification (Hooper et al. 2002). However, this method is used in few studies. It was argued by some researchers that functional classification is context-dependent and thus useful functional groups at global scale may not be expected (Bugmann 1996; Noble \& Gitay 1996). On the other hand, repeatable patterns of functional traits suggest that functional groups may be applicable across regions (Wright et al. 2004; Sasaki et al. 2011). Considering the definition of functional groups, it is expected that they are formed rather by habitat filters and niche similarities than by biogeographic regions (Cornwell et al. 2006; Lebrija-Trejos et al. 2010; Maire et al. 2012). For instance, in floristically different regions, similar trait combinations are associated with grazing (Díaz et al. 2001). However, global application of plant traits needs methodological standardization in definition of traits and their attributes, as well as rules for collecting and measuring (handbook of standardized traits by (Cornelissen et al. 2003; Pérez-Harguindeguy et al. 2013). Unification of trait-related terminology should avoid misunderstanding and misinterpretation of functional studies. In this context, several concepts and glossary papers are published (Violle et al. 2007; Harrington et al. 2010). Global trait databases are the next step in functional studies on various scales (e.g. TRY, Kattge et al. 2011).

\section{Ecological values of the functional approach}

Functional approaches offers advantages in ecological studies. They are mainly used for dealing with community and ecosystem processes or for predicting ecological changes (reviewed in (Duckworth et al. 2000). In the following sections the importance of functional traits in ecological studies are summarized.

Functional groups respond well to the need of generalization and globalization in biogeography and ecology. In contrast to species-based approach, classified functional traits should be potentially applicable to other regions. Therefore, they are suitable for studies between regions which share no or only few species (chapter 2, Mahdavi \& Bergmeier 2016). Functional traits are reflecting the environmental filters. Thus, using morphological and physiological traits to study communities can help in identification of general patterns in ecology and even may extend the ecological aspect into phylogenetic structures and trait evolution (McGill et al. 2006; Shipley et al. 2006). Another advantage of using functional groups based on cluster analysis is that new species can be added to the existing functional groups which is very useful in ecological studies (Fry et al. 2014).

Functional traits provide new perspectives in ecological studies. For example, functional approaches allow quantifying species niches in units of traits instead of environmental parameters. It was shown that mean trait values of a species determine its niche position along gradients and intraspecific trait variability determines its niche breadth (Violle \& Jiang 2009). Trait syndromes are useful for defining 
the characters of a habitat. They refer to groups of co-occurring traits that express adaptation to particular environmental condition (Harrington et al. 2010). Furthermore, functional approaches are an effective complementary tool to traditional phytosociology for describing diagnostic species and vicariant plant communities especially when comparing different biogeographical regions (chapter 3, Mahdavi et al. 2017).

Functional diversity adds a new aspect to ecological diversity. It is a quite new concept dealing with niche partitioning and different species assemblage (Petchey 2004). The more species-rich a functional group, the more stable the ecosystem as species of the same function can replace each other and thus consequences of extinction are less serious (Duckworth et al. 2000). Community weighted trait mean which is a measure of functional diversity can be applied for assessing ecosystem properties and services (Díaz et al. 2007; de Bello et al. 2010). Diversity of functional traits of species in a community should be incorporated into conservation and restoration activities (reviewed in Cadotte et al. 2011). However, measuring functional diversity is a challenging task as many indices have been proposed using different methods for estimating the functional dissimilarity which can affect the results (Petchey et al. 2004; Ricotta 2005; Schleuter et al. 2010; Mason et al. 2013; de Bello et al. 2013). For choosing the proper diversity index these questions need to be considered: how many and which traits to use, how to combine traits which measured in different scale, and how to weight the traits by abundance of species (Lepš et al. 2006; Petchey \& Gaston 2006; Mason \& de Bello 2013).

Functional groups are especially useful for modeling biodiversity and predicting ecological changes (Lavorel \& Garnier 2002; Boulangeat et al. 2012) as they reduce the number of variables to consider in the analysis. (Bonan et al. 2002 examined to consider landscape as patches of plant functional types for modeling climate and ecosystem. Plant traits are considered as a powerful tool for predicting species assemblages across different habitats and environmental gradients (Douma et al. 2012).

Beside species- and habitat-based approaches, functional traits can be considered as another component for the application in nature conservation. Functional groups are helpful when information about some species of the habitat are lacking. Species of the same functional group will receive the same management which facilitate delivery of preliminary recovery actions (Kooyman \& Rossetto 2008). In this context, BIOPOP is a plant trait database made for species of Germany providing information for conservation purposes (Poschlod et al. 2003). Diverse researches suggest that functional groups can be used for identifying conservation priorities and suitable management policy and to evaluate the effect of environmental stress on target functional groups of habitat (e.g. García-Mora et al. 1999; Quétier et al. 2007). 


\section{C4 photosynthesis, a complex trait}

\section{Diversity of photosynthetic types}

The oldest and most common photosynthesis type among plants is the $\mathrm{C}_{3}$ pathway (Sage 2005). Carbon fixation in C3 pathway is started by Rubisco (ribulose 1,5-bisphosphate carboxylase/oxygenase) which is both, a carboxylase and oxygenase enzyme. Product of carbon fixation runs the Calvin cycle for producing sugar. Both carbon fixation and Calvin cycle occur in mesophyll cells. The oxygenate activity of Rubisco results in photorespiration and reduces the overall efficiency of photosynthesis.

C4 syndrome is a combination of anatomical, physiological and biochemical modifications in the photosynthetic pathway which increases the concentration of $\mathrm{CO}_{2}$ around Rubisco and reduces photorespiration (Sage 2004). In contrast to C3 ones, the carbon fixation is performed by PEPC (phosphoenolpyruvate carboxylase) in mesophyll cells and results in a four-carbon organic acid (Oxaloacetate, OAA) which then is transformed and transfered to the bundle sheath cells (Covshoff et al. 2014). There, the four-carbon acid is decarboxylated to release $\mathrm{CO}_{2}$ that is taken by Rubisco to start the Calvin cycle and produce sugar. Spatial separation of $\mathrm{CO}_{2}$ uptake (mesophyll) and Calvin cycle (bundle sheath) provides high concentration of $\mathrm{CO}_{2}$ for Rubisco and prevents its contact to $\mathrm{O}_{2}$. Therefore, oxygenate activity of the enzyme is blocked leading to high photosynthesis efficiency.

Based on the type of the decarboxylation enzyme, three biochemical subtypes among $\mathrm{C} 4$ plants are identified: NADP-malic enzyme where OAA is converted to malate which is then transferred to interior compartment, NAD-malic enzyme where OAA is transformed to aspartate and the third one is phosphoenolpyruvate carboxykinase (PCK) which produces PEP during the carboxylation (Sage 2004; Christin \& Osborne 2014). All three subtypes occur in grasses while eudicots have only NADP-ME and NAD-ME (Sage 2004). The most common subtype is NADP-ME which can be found in both monocots and dicots (Christin et al. 2009).

In most C4 plants, two distinct cell types are required for the function of $\mathrm{C} 4$ pathway. An inner layer (bundle sheath) consisting of enlarged, compact, thick-walled cells with high chloroplast content which is surrounded by an outer layer (mesophyll) with radiate, thin-walled cells (Muhaidat et al. 2007; Lundgren et al. 2014). This structure is known as Kranz anatomy with eight major types among different C4 lineage (Dengler \& Nelson 1999). Five of these types occur in Chenopodiaceae (Atriplicoid, Kochioid, Salsoloid, Suaedoid, and Conospermoid) (Edwards et al. 2004).

In addition, a small group of plants with $\mathrm{C} 4$ pathway does not feature Kranz anatomy. In this group all $\mathrm{C} 4$ reaction occurs in a single cell. This group includes Suaeda aralocaspica (=Borszczowia) and three 
species of Bienertia (B. sinuspersici, B. cycloptera, B. kavirense) (Voznesenskaya et al. 2001; Sage 2016).

The third common type of photosynthesis is crassulacean acid metabolism (CAM). It is similar to C4 pathway in concentrating $\mathrm{CO}_{2}$ and producing a four-carbon acid. However instead of a spatial separation as in $\mathrm{C} 4$ plants, CAM species exhibit a temporal separation of carbon fixation (during night) and Calvin cycle (during day) (Ehleringer \& Monson 1993). Therefore, the stomata can stay close during the day while decarboxylation of four-carbon acid releases $\mathrm{CO}_{2}$ and Rubisco operates under high concentration of $\mathrm{CO}_{2}$. CAM is a highly efficient pathway in dry and hot regions and is frequently found in succulent plants such as Cactaceae, Bromeliaceae, Crassulaceae and Polypodiaceae (Ehleringer \& Monson 1993).

\section{Evolutionary pressure}

Phylogenetic studies indicate that all $\mathrm{C} 4$ lineages evolved under low atmospheric $\mathrm{CO}_{2}$ condition of the post-Oligocene (reviewed in (Sage \& Stata 2015). The first origins of C4 grasses arose in the late Oligocene (ca. 30 million years ago) where the most severe drop in atmospheric $\mathrm{CO}_{2}$ occurred; however C4 grasslands expanded in the late Miocene (5-8 million years ago) (Bouchenak-Khelladi et al. 2009). Low atmospheric $\mathrm{CO}_{2}$ partial pressure $\left(\mathrm{pCO}_{2}\right)$ and high temperature are considered as a main selective force for driving evolution of C4 photosynthetic pathway (Ehleringer et al. 1997). C4 and C3 plants respond differently to variation in temperature and $\mathrm{pCO}_{2}$. This concept is well explained in crossover temperature hypothesis (Ehleringer 1978). Crossover temperature is defined as a temperature at which the quantum yield of photosynthetic $\mathrm{CO}_{2}$ fixation is equal for both $\mathrm{C} 3$ and $\mathrm{C} 4$ species at a certain $\mathrm{pCO}_{2}$, which is at about $22^{\circ} \mathrm{C}$ (Collatz et al. 1998). Following this hypothesis, $\mathrm{C} 3$ plants have a higher efficiency below $22^{\circ} \mathrm{C}$ whereas above $30^{\circ} \mathrm{C}$ is in favor of $\mathrm{C} 4$ plants. Collatz et al. (1998) modeled the current distribution of $\mathrm{C} 4$ plants based on $\mathrm{pCO}_{2}$ and crossover temperature in the past and provide a good base for predicting the changes in $\mathrm{C} 3-\mathrm{C} 4$ vegetation in the future. However, there are also other factors influencing the distribution of $\mathrm{C} 4$ plants as e.g. changing climate as well as fire and herbivory. The latter factors might be involved in the creation of open habitats which was required for C4 expansion at the Miocene as most C4 species cannot tolerate shade (Osborne \& Beerling 2006). $\mathrm{CO}_{2}$ enrichment, global climate warming, terrestrial eutrophication, bioinvasions and human altering of landscapes are significant modifiers of $\mathrm{C} 3 / \mathrm{C} 4$ dynamics.

\section{Origin and diversity of $\mathrm{C} 4$ plants}

$\mathrm{C} 4$ photosynthesis has evolved independently more than 60 times in flowering plants and 22-24 times in grasses (Christin et al. 2013). All origins of C4 grasses occurred in PACMAD clade (Grass 
Chapter 1: Introduction |

Phylogeny Working Group II 2012), consisting of six subfamilies (Panicoideae, Arundinoideae, Chloridoideae, Micrairoideae, Aristidoideae and Danthonioideae; including both C3 and C4 species). Their sister clade BEP (Bambusoideae, Ehrhartoideae and Pooideae) diverged from PACMAD ca. 50 million years ago (Taylor et al. 2011). Phylogenetical evidences suggest that PACMAD lineages (whether they are $\mathrm{C} 4$ or not) are adapted to warmer regions while BEP lineages occurred in colder regions (Edwards et al. 2010). It is assumed that habitat preferences of C4 species is not only influenced by their photosynthetic trait but also is correlated with their phylogeny and other traits which they inherited from their C3 ancestors (Taub 2000). Phylogenetic analyses within lineages of PACMAD reveals that C4 lineages occur in drier habitats than their C3 relatives (Pau \& Still 2014; Taylor et al. 2014). Therefore, distribution patterns of C3 and C4 grasses reflect the distribution patterns of Pooideae/PACMAD and it is not clear to what extent C4 syndrome is contributing to this trend (Edwards \& Still 2008). Ecophysiological differences between subfamilies of PACMAD confirm that phylogeny is associated with habitat preferences of C4 lineages (Taylor et al. 2010). On the other hand, (Osborne \& Freckleton 2009) showed that C4 photosynthesis is a pre-adaptation to arid condition explaining the high occurrence of $\mathrm{C} 4$ lineages in arid region. Their analysis on the phylogeny of grasses confirms that open habitats are necessary for selection of $\mathrm{C} 4$ pathway but the evolution may take place in arid, saline or mesic conditions of open habitats. However, when the pathway has evolved, C4 lineages have adapted more rapidly to arid and saline habitats than C3 lineages (Osborne \& Freckleton 2009).

First origin of C4 plants date back to ca. 30 million years ago (Sage \& Stata 2015). Although, first origins of monocots and dicots arose almost in the same time but some C4 lineages of dicots evolved more recently. The youngest being Flaveria that evolved 2 million years ago (Christin et al. 2011). The majority of $\mathrm{C} 3$ ancestors of $\mathrm{C} 4$ plants and $\mathrm{C} 3-\mathrm{C} 4$ intermediate forms have been identified among the eudicots such as the genera Salsola, Heliotropium, Alternanthera, Moricandia, Mollugo and Flaveria (Sage et al. 2011). In grasses however, there are only two C3-C4 intermediate genera: Steinchisma and Neurachne (Sage et al. 2011) and one species (Alloteropsis semialata) with C3, C4 and C3-C4 populations (Lundgren et al. 2016). Intermediate species are important for studying the evolutionary transition from $\mathrm{C} 3$ to $\mathrm{C} 4$.

C4 species occur in 16 families of dicots in which Chenopodiaceae and Amaranthaceae have the highest number of $\mathrm{C} 4$ species followed by Euphorbiaceae and Asteraceae. Other dicot families with recorded C4 species are: Zygophyllaceae, Brassicaceae, Scrophulariaceae, Acanthaceae, Boraginaceae, Polygonaceae, Caryophyllaceae, Aizoaceae, Gisekiaceae, Nyctaginaceae, Molluginaceae and Portulacaceae (Sage 2005). 
Pre-adaptation of $\mathrm{C} 4$ photosynthesis to arid condition was shown also for dicots. Phylogenetic studies confirm that C4 lineages evolved from the C3 ancestors which already adapted to arid conditions (Christin \& Osborne 2014). Similar results were gained for Chenopodiaceae, C3 chenopods that were more tolerant to salinity evolved as C4 halophytes (Kadereit et al. 2012). One should also consider that salinity is associated with aridity as it decreases water availability and causes physiological drought. Adaptation to arid condition is important for species to inhabit the arid interiors of continents where most C4 dicot lineages occur (Sage 2005). An evolutionary hypothesis for C4 halophytes is explained by the occurrence of Bienertia spp. and Suaeda aralocaspica (single-celled C4 species) in extreme saline soils beyond tolerance of C3 halophytes. Sage (2005) suggests some evolutionary stages of C3C4 intermediates along salinity gradient which at each stage intermediate species colonized areas with greater salinity where their C3 relatives were unable to survive. This process is continued until full evolution of $\mathrm{C} 4$ pathway. Therefore, salinity should have worked as a selection pressure for the evolution of $\mathrm{C} 4$ pathway in $\mathrm{C} 4$ halophytes.

Considering diversity of $\mathrm{C} 4$ groups including biochemical and anatomical subtypes and different $\mathrm{C} 4$ lineages, it is suggested to integrate physiological and anatomical studies in a phylogenetic context to better understand the evolution of C4 plants (Christin, Salamin, et al. 2009; Christin et al. 2013).

\section{Study area}

\section{Irano-Turanian region}

The Alborz mountain range in N Iran, with the height of $5671 \mathrm{~m}$ at the peak of Demavand, works as a barrier and separates the humid part in south of the Caspian Sea from the interior part of the Iranian plateau. The northern part belongs to Euro-Siberian phytogeograophic region (Hyrcanian province) and the southern part belongs to the Irano-Turanian region.

The Irano-Turanian region is one of the hotspots of biodiversity and serves as a source of xerophytic taxa for neighboring regions (Manafzadeh et al. 2014; Manafzadeh et al. 2016). It is characterized by continental climate, low precipitation, hot and dry summer and cold winter, cushion form vegetation and dwarf shrubs with high number of endemic species (Zohary 1973). The Irano-Turanuan region forms a distinct bioclimatic area in SW and Central Asia which is more continental than Mediterranean climate and has different seasonality patterns of precipitation (Djamali et al. 2012).

Central Iran: southern shore of the Namak Lake (Daryacheh-ye Namak) in the Maranjab Desert (34 9-19' $\left.\mathrm{N}, 51^{\circ} 30-56^{\prime} \mathrm{E}\right)$ was studies. It is a large saline playa surrounded by halo- phytic communities and sand dunes. Mean monthly temperatures vary between $5^{\circ} \mathrm{C}$ (January) and $33^{\circ} \mathrm{C}$ (July). The annual precipitation is $136 \mathrm{~mm}$ (http://www.chbmet.ir/iranarchive.asp). 
Chapter 1: Introduction |

\section{Hyrcanian region}

This region in Iran is extended along the southern shore of the Caspian Sea. The Western part of the Hyrcanian region has higher precipitation than the eastern part. The region is characterized by a warm humid climate with rainy summers and mild winters. The Hyrcanian forests are significant in the region and known as refugia for many relict elements. The large parts of the sand habitat along the coast are degraded and fragmented due to intensive human activities (Akhani et al. 2010).

$N$ Iran: the SE Caspian Sea shore was investigated, including the Miankaleh Biosphere Reserve $\left(36^{\circ}\right.$ $48-55^{\prime} \mathrm{N}, 53^{\circ} 25^{\prime}-54^{\circ} 02^{\prime} \mathrm{E}$ ) with $50 \mathrm{~km}$ of (semi-)natural coastline, and two other sites westward $\left(36^{\circ}\right.$ $\left.49^{\prime} \mathrm{N}, 53^{\circ} 8^{\prime} \mathrm{E}, 36^{\circ} 39^{\prime} \mathrm{N}, 52^{\circ} 22^{\prime} \mathrm{E}\right)$. Miankaleh wildlife refuge is located in south-east of the Caspian Sea, with the total area of 68800 ha and consisted of two terrestrial and aquatic ecosystems. It is characterized by diverse habitats, supporting variety of wildlife, migratory birds and different vegetation and plant species. The mean temperature of the coldest month (January) is $8.7{ }^{\circ} \mathrm{C}$ and the warmest month is August with mean temperatures of ca. $28^{\circ} \mathrm{C}$. The mean annual precipitation is 789 mm (http://www.chbmet.ir/iranarchive.asp).

\section{Mediterranean region}

This region is known for high biodiversity and high rate of endemism (Médail \& Quézel 1999). Disturbances such as fire and grazing play an important role in dynamic and structure of the vegetation (Cowling et al. 1996; Pausas et al. 2008). The climate is characterized by hot, dry summers and humid, cool winters.

NE Greece: The study area along the North Aegean coast runs approximately $300 \mathrm{~km}$ from south of Katerini (40 $\left.09^{\prime} \mathrm{N}, 22^{\circ} 33^{\prime} \mathrm{E}\right)$ eastward to Porto Lagos (40 $\left.54^{\prime} \mathrm{N}, 25^{\circ} 23^{\prime} \mathrm{E}\right)$. Mean monthly temperatures vary between $5-7{ }^{\circ} \mathrm{C}$ (January) and $25-27{ }^{\circ} \mathrm{C}$ (July). Mean annual rainfall is 400-600 mm (Lienau 1989).

\section{Atlantic region}

The region stretches along the North Sea and North-east Atlantic Ocean. It is characterized by oceanic climate, mile winters, cool summers, moderate rainfall throughout the year and westerly winds. The natural and semi-natural habitats are heavily fragmented through urbanization and agriculture and only isolated patches are existed (Sundseth 2009).

$N$ Germany: The data from the coastal area along the North Sea from the island of Borkum $\left(53^{\circ} 36^{\prime} \mathrm{N}\right.$, $\left.6^{\circ} 43^{\prime} \mathrm{E}\right)$ eastward to the island of Fehmarn $\left(54^{\circ} 28^{\prime} \mathrm{N}, 11^{\circ} 08^{\prime} \mathrm{E}\right)$ at the Baltic Sea coast was analyzed. 
Mean monthly temperatures for the North Sea (Island of Norderney) vary between $3{ }^{\circ} \mathrm{C}$ (January) and $18{ }^{\circ} \mathrm{C}$ (July). Mean annual rainfall is about $801 \mathrm{~mm}$, with higher amounts from July to December.

\section{General description of methods}

\section{Data collection}

\section{Vegetation sampling}

The field data were collected during the summer 2011 and 2012 in sand ecosystems of the Mediterranean, Hyrcanian and Irano-Turanian. In the Atlantic region, the data base of Coastal Vegetation Germany (GIVD code: EU-DE-035) was included in the analysis of the second study (chapter 3). In each region the following habitats were surveyed: drift lines, mobile dunes, semi-wet habitats (dune slacks), stabilized dunes, salt marshes and disturbed sandy grounds. The plots were made randomly in the homogenous vegetation types with distance of at least 50-100 m to avoid the spatial autocorrelation. The vascular plant composition was recorded in plots of $25 \mathrm{~m}^{2}$ using BraunBlanquet cover-abundance scale (Dierschke 1994). In addition, the total plant cover, the shrub and herb cover, the max. herb and shrub height and the environmental variables (geographic coordinates, slope, aspect, elevation a.s.l. and the soil texture) were recorded. The vegetation survey data sheet and the Braun-Blanquet cover-abundance scales are provided in the appendix A.

Plant nomenclature follows Flora Iranica (Rechinger 1963-2012), Dimopoulos et al. (2013) and Florenliste von Deutschland (Buttler et al. 2015) for Iran, Greece and Germany respectively; syntaxonomic nomenclature follows mainly Mucina et al. (2016) for Greece and Germany, and Asri (2003) for Iran.

\section{Trait sampling}

We used fourteen categorical traits for the functional trait analysis. Categorical traits can be measured or obtained from the literature and are especially useful for areas without established trait databases. They also facilitate repeating and comparing the approach in other areas. The traits were selected from different parts of plants to better reflect the adaptive response patterns of species to the environment (Cornelissen et al. 2003). For standardization, the protocol for functional traits (Pérez-Harguindeguy et al. 2013) was followed. The recorded species were assigned to the traits based on the given attributes in Table 1 (chapter 2). Original trait information was obtained mainly from the collected specimens and field observation, but also from floras (Rechinger 1963-2012) and other resources (especially for plant strategies and regenerative traits Grime et al. 2007; Klotz et al. 2002). 
Chapter 1: Introduction |

In case of the life form, we merged geophytes with hemicryptophytes as there are very few species of geophytes among the sampled species which we have preferred to merge them rather than omitting them from the study. The Plant height was mostly measured and partly taken from floras. They were divided then into four height classes as for our purposes it was sufficient to know whether plants in different habitats have small, medium or large size. To deal with such quantitative traits in analyses, they should be scaled from 0 (minimum value) to 1 (maximum value) and then the other heights could be scaled within this range (more information in (Lepš \& de Bello 2008). For example, in our case class one is 0.25 , class two is 0.5 , class three is 0.75 , and class four is 1 . The data on the photosynthetic pathway of species were obtained from the literatures (more details in chapter 4, Table 2).

\section{Data analysis}

In this thesis, the collected data were examined mainly by means of multivariate analysis in forms of classification and ordination to find out the main gradients and/or groups. The general overview of the applied methods is provided in this section and the detailed information on the 'methods' section of each chapter.

The trait data built of all species and trait variables were classified by using cluster analysis (Ward's method with relative Euclidean distance) in order to define the functional groups of plants. The cluster cut level was determined manually so that the resulting groups were interpretable. Vegetation classification was performed separately for each region using TWINSPAN with three pseudospecies cut levels $(0,2,5)$. After manual editing of generated groups, synoptic tables were created, and diagnostic species were determined using percentage frequency (constancy) values. The plant communities were assigned to the high-rank syntaxa and when possible to the association using the available literature.

We used Detrended Correspondence Analysis (DCA) to understand the distribution of functional traits and groups in sand habitats and to estimate the vegetation dissimilarities over regions and habitats. The DCA analysis was run on the matrix of specie-plot, trait-plot and FG-plot. The trait-plot matrix was built by multiplying the trait-species matrix by the matrix of species-plot. To make a FG-plot matrix for a given region, the composition of functional groups for each plot was calculated.

\section{Objectives and thesis outline}

The main aim of this thesis was to explore sand ecosystems beyond the regional borders by defining the main functional groups in the ecosystem using plant traits, to analyze the effect of habitat and region on adaptive characters of species, to discover the similarity of sand habitats at species, 
community and functional level, and to investigate the distribution of photosynthesis types across different sand habitats.

In chapter 2, the functional traits of plant species in sand ecosystems across different climatic regions are investigated. The main functional groups (group of species with similar functional traits) are defined by cluster analysis. It is hypothesized that functional groups and the functional affiliation of sand dune species are mainly determined by habitat characteristics and niches, independent of the climatic region in which they occur. To test this hypothesis, functional groups are examined in context of the habitat types (mobile dunes, stabilized dunes, salt marshes, semi-wet sand and sandy disturbed habitat) and climatic regions in which they occur (Mediterranean, Hyrcanian and Irano-Turanian) and results between inland and coastal sand systems are compared. Furthermore, the trait syndromes (groups of co-occurring traits that express adaptation to environmental condition) which are associated with particular habitats in sand dune systems are determined.

In chapter 3, the effect of habitat and region on sand dune vegetation is investigated by comparing its similarities at species, community and functional level. At each level similarity in habitats of the same kind across regions as well as in a given region across different sand habitats is considered. Four saline habitat types (drift lines, mobile dunes, stabilized dunes, and salt marshes) in four phytogeographic regions ranging from the Atlantic coasts to Irano-Turanian salt lake shores are examined. The plant communities for each habitat type are defined and the importance of using a functional approach in classical phytosociology is discussed. Specifically the chapter addresses the question whether vegetation of the same habitat type is similar across different phytogeographical regions and which kinds of similarity are more pronounced. It is analyzed to what extent sand habitats represent an azonal vegetation with respect to taxonomic (species and genera), syntaxonomic and functional similarity. Furthermore the syntaxonomical and functional analogues across regions are determined.

Focus of the study in chapter 4 is on photosynthetic pathway trait and the distribution of $\mathrm{C} 4$ plants in habitats of sand dune ecosystems. Proportion of $\mathrm{C} 4$ plants and their contribution to total vegetation cover are analyzed. The habitat preferences of $\mathrm{C} 4$ plants, the potential drivers of $\mathrm{C} 4$ plants (such as aridity, salinity, temperature, and precipitation) are discussed. It is hypothesized that the hot and dry conditions of sand habitats favor plants with $\mathrm{C} 4$ photosynthetic pathway. $\mathrm{C} 4$ species cover, richness and $\mathrm{C} 3 / \mathrm{C} 4$ ratio in five sand habitats is analyzed to answer the following research questions: How are $\mathrm{C} 4$ plants distributed in different habitats of sand ecosystems and what are their habitat preferences? Do C4 plants have larger biomass than ecologically similar C3 plants? Do regional climatic differences affect the occurrence and proportion of $\mathrm{C} 4$ plants? 
Chapter 1: Introduction |

In chapter 5, the main findings of the research are summarized and discussed in a wider ecological context. Open questions and future research perspectives are declared. 
Chapter 1: Introduction |

\section{References}

Asri, Y. 2003. Plant diversity in Kavir Biosphere Reserve, Iran. Research Institute of Forests and Rangelands, Tehran. [In Persian.]

Acosta, a., Carranza, M.L., \& Izzi, C.F. 2009. Are there habitats that contribute best to plant species diversity in coastal dunes? Biodiversity and Conservation 18: 1087-1098.

Acosta, A., Ercole, S., Stanisci, A., \& Blasi, C. 2004. Sandy coastal ecosystems and effects of disturbance in central Italy. Journal of Coastal Research SI 39:

Acosta, A., Ercole, S., Stanisci, A., Pillar, V.D.P., \& Blasi, C. 2007. Coastal Vegetation Zonation and Dune Morphology in Some Mediterranean Ecosystems. Journal of Coastal Research 236: 15181524.

Akhani, H., Djamali, M., Ghorbanalizadeh, A., \& Ramezani, E. 2010. Plant biodiversity of Hyrcanian relict forests, N Iran: An overview of the flora, vegetation, palaeoecology and conservation. Pakistan Journal of Botany 42: 231-258.

Barbour, M.G. 1972. Seedling establishment of Cakile maritima at Bodega Head, California. Bulletin of the Torrey Botanical Club 99: 11-16.

Barbier, E.B., Hacker, S.D., Kennedy, C., Koch, E.W., Stier, a. C., \& Silliman, B.R. 2011. The value of estuarine and coastal ecosystem services. Ecological Monographs 81: 169-193.

Buttler, K.P., Thieme, M., \& Mitarbeiter. 2015. Florenliste von Deutschland-Gefäßpflanzen, Version 7. Frankfurt am Main, DE. URL: http://www.kp-buttler.de/

de Bello, F., Carmona, C.P., Mason, N.W.H., Sebastià, M.-T., \& Lepš, J. 2013. Which trait dissimilarity for functional diversity: trait means or trait overlap? (M. Zobel, Ed.). Journal of Vegetation Science 24: 807-819.

de Bello, F., Lavorel, S., Díaz, S., Harrington, R., Cornelissen, J.H.C., Bardgett, R.D., Berg, M.P., Cipriotti, P., Feld, C.K., Hering, D., Martins da Silva, P., Potts, S.G., Sandin, L., Sousa, J.P., Storkey, J., Wardle, D. a., \& Harrison, P. a. 2010. Towards an assessment of multiple ecosystem processes and services via functional traits. Biodiversity and Conservation 19: 2873-2893.

Bonan, G.B., Levis, S., Kergoat, L., \& Oleson, K.W. 2002. Landscapes as patches of plant functional types: An integrating concept for climate and ecosystem models. Global Biogeochemical Cycles 16: $1-23$.

Bouchenak-Khelladi, Y., Anthony Verboom, G., Hodkinson, T.R., Salamin, N., Francois, O., Ní Chonghaile, G., \& Savolainen, V. 2009. The origins and diversification of C 4 grasses and 
Chapter 1: Introduction |

savanna-adapted ungulates. Global Change Biology 15: 2397-2417.

Boulangeat, I., Philippe, P., Abdulhak, S., Douzet, R., Garraud, L., Lavergne, S., Lavorel, S., Van Es, J., Vittoz, P., \& Thuiller, W. 2012. Improving plant functional groups for dynamic models of biodiversity: at the crossroads between functional and community ecology. Global change biology 18: 3464-3475.

Buffa, G., Fantinato, E., \& Pizzo, L. 2012. Effects of disturbance on sandy coastal ecosystems of NAdriatic coasts (Italy). In Lameed, G.A. (ed.), Biodiversity enrichment in a diverse world, pp. 339-372. InTech, Croatia.

Bugmann, H. 1996. Functional Types of Trees in Temperate and Boreal Forests : Classification and Testing. Journal of Vegetation Science 7: 359-370.

Cadotte, M.W., Carscadden, K., \& Mirotchnick, N. 2011. Beyond species: functional diversity and the maintenance of ecological processes and services. Journal of Applied Ecology 48: 1079-1087.

Christin, P.-A., \& Osborne, C.P. 2014. The evolutionary ecology of C4 plants. New Phytologist 204: $765-781$.

Christin, P.-A., Osborne, C.P., Chatelet, D.S., Columbus, J.T., Besnard, G., Hodkinson, T.R., Garrison, L.M., Vorontsova, M.S., \& Edwards, E.J. 2013. Anatomical enablers and the evolution of C4 photosynthesis in grasses. Proceedings of the National Academy of Sciences of the United States of America 110: 1381-6.

Christin, P.A., Osborne, C.P., Sage, R.F., Arakaki, M., \& Edwards, E.J. 2011. C4 eudicots are not younger than C4 monocots. Journal of Experimental Botany 62: 3171-3181.

Christin, P.-A., Salamin, N., Kellogg, E. a, Vicentini, A., \& Besnard, G. 2009. Integrating phylogeny into studies of C4 variation in the grasses. Plant physiology 149: 82-7.

Christin, P.-A., Samaritani, E., Petitpierre, B., Salamin, N., \& Besnard, G. 2009. Evolutionary insights on $\mathrm{C} 4$ photosynthetic subtypes in grasses from genomics and phylogenetics. Genome biology and evolution 1: 221-30.

Collatz, G.J., Berry, J. a., \& Clark, J.S. 1998. Effects of climate and atmospheric $\mathrm{CO}_{2}$ partial pressure on the global distribution of C4 grasses: present, past, and future. Oecologia 114: 441-454.

Cornelissen, J.H.C., Lavorel, S., Garnier, E., Díaz, S., Buchmann, N., Gurvich, D.E., Reich, P.B., Steege, H. Ter, Morgan, H.D., Heijden, M.G. a. Van Der, Pausas, J.G., \& Poorter, H. 2003. A handbook of protocols for standardised and easy measurement of plant functional traits worldwide. Australian Journal of Botany 51: 335-380. 
Cornwell, W.K., Schwilk, D.W., \& Ackerly, D.D. 2006. A trait-based test for habitat filtering: convex hull volume. Ecology 87: 1465-71.

Covshoff, S., Burgess, S.J., Kneřová, J., \& Kümpers, B.M.C. 2014. Getting the most out of natural variation in C4 photosynthesis. Photosynthesis Research 119: 157-167.

Cowling, R.M., Rundel, P.W., Lamont, B.B., Arroyo, M.K., \& Arianoutsou, M. 1996. Plant diversity in mediterranean-climate regions. Trends in Ecology and Evolution 11: 362-366.

Danin, A., 1996. Plants of Desert Dunes: Adaptation of Desert Organisms. Springer, Berlin.

Defeo, O., McLachlan, A., Schoeman, D.S., Schlacher, T. a., Dugan, J., Jones, A., Lastra, M., \& Scapini, F. 2009. Threats to sandy beach ecosystems: A review. Estuarine, Coastal and Shelf Science 81: 1-12.

Dengler, N.G., Nelson. T. 1999. Leaf structure and development in C4 plants. See Ref. 60a, pp. 13372.

Díaz, S., Lavorel, S., de Bello, F., Quétier, F., Grigulis, K., \& Robson, T.M. 2007. Incorporating plant functional diversity effects in ecosystem service assessments. Proceedings of the National Academy of Sciences 104: 20684-9.

Díaz, S., Noy-meir, I., \& Cabido, M. 2001. Can grazing response of herbaceous plants be predicted from simple vegetative traits? Journal of Applied Ecology 38: 497-508.

Dierschke, H. 1994. Pflanzensoziologie - Grundlagen und Methoden. Ulmer, Stuttgart, DE.

Dimopoulos, P., Raus, T., Bergmeier, E., Constantinidis, T., Iatrou, G., Kokkini, S., Strid, A., \& Tzanoudakis, D. 2013. Vascular plants of Greece: An annotated checklist. [Englera 31] Botanic Garden and Botanical Museum Berlin-Dahlem, Berlin, DE, and Hellenic Botanical Society, Athens, GR.

Djamali, M., Brewer, S., Breckle, S.W., \& Jackson, S.T. 2012. Climatic determinism in phytogeographic regionalization: A test from the Irano-Turanian region, SW and Central Asia. Flora: Morphology, Distribution, Functional Ecology of Plants 207: 237-249.

Doing, H. 1985. Coastal fore-dune zonation and succession in various parts of the world. Vegetatio 61: 65-75.

Douma, J.C., Aerts, R., Witte, J.P.M., Bekker, R.M., Kunzmann, D., Metselaar, K., \& van Bodegom, P.M. 2012. A combination of functionally different plant traits provides a means to quantitatively predict a broad range of species assemblages in NW Europe. Ecography 35: 364-373.

Duckworth, J.C., Kent, M., \& Ramsay, P.M. 2000. Plant functional types: an alternative to taxonomic 
Chapter 1: Introduction |

plant community description in biogeography? Progress in Physical Geography 24: 515-542.

Edwards, G.E., Franceschi, V.R., \& Voznesenskaya, E. V. 2004. Single-cell C4 photosynthesis versus the dual-cell (Kranz) paradigm. Annual review of plant biology 55: 173-96.

Edwards, E.J., Osborne, C.P., Strömberg, C. a E., Smith, S. a, Bond, W.J., Christin, P.-A., Cousins, A.B., Duvall, M.R., Fox, D.L., Freckleton, R.P., Ghannoum, O., Hartwell, J., Huang, Y., Janis, C.M., Keeley, J.E., Kellogg, E. a, Knapp, A.K., Leakey, A.D.B., Nelson, D.M., Saarela, J.M., Sage, R.F., Sala, O.E., Salamin, N., Still, C.J., \& Tipple, B. 2010. The origins of C4 grasslands: integrating evolutionary and ecosystem science. Science (New York, N.Y.) 328: 587-91.

Edwards, E.J., \& Still, C.J. 2008. Climate, phylogeny and the ecological distribution of C4 grasses. Ecology Letters 11: 266-276.

EEA, European Environment Agency. 2008. Article 17 Technical Report 2001-2006, Brussels. Ellenberg, H., \& Leuschner, C. 2010. Vegetation Mitteleuropas mit den Alpen in ökologischer, dynamischer und historischer Sicht. 6th ed. Ulmer, Stuttgart, DE.

Ehleringer, J.R. 1978. Implications of Quantum yield differences on the distribution of C3 and C4 grasses. Oecologia 31: 255-267.

Ehleringer, J.R., Cerling, T.E., \& Helliker, B.R. 1997. C4 photosynthesis, atmospheric $\mathrm{CO}_{2}$ and climate. Oecologia 112: 285-299.

Ehleringer, J.R., \& Monson, R.K. 1993. Evolutionary and Ecological Aspects of Photosynthetic Pathway Variation. Annual Review of Ecology and Systematics 24: 411-439.

European Commission. 2013. Natura 2000. Interpretation Manual of European Union Habitats. EUR28. DG Environment, Brussels, BE.

Everard, M., Jones, L., \& Watts, B. 2010. Have we neglected the societal importance of sand dunes? An ecosystem services perspective. Aquatic Conservation: Marine and Freshwater Ecosystems 20: $476-487$.

Fahn, A. \& Cutler, D.F. 1992. Xerophytes. Borntraeger. Berlin. DE.

Fry, E.L., Power, S. a., \& Manning, P. 2014. Trait-based classification and manipulation of plant functional groups for biodiversity-ecosystem function experiments (A. Prinzing, Ed.). Journal of Vegetation Science 25: 248-261.

García-Mora, M.R., Gallego-Fernández, J.B., \& García-Novo, F. 1999. Plant functional types in coastal foredunes in relation to environmental stress and disturbance. Journal of Vegetation 
Science 10: 27-34.

Gitay, H., Noble, I.R., 1997. What are functional types and how should we seek them? In: Smith, T.M., Shugart, H.H., Woodward, F.I. (Eds.), Plant functional types: their relevance to ecosystem properties and global change. Cambridge University Press, Cambridge.

Grass Phylogeny Working Group II. 2012. New grass phylogeny resolves deep evolutionary relationships and discovers C4 origins. New Phytol 193(2): 304-312.

Grime, J.P. 2006. Plant strategies, vegetation processes, and ecosystem properties. 2nd ed. John Wiley $\&$ Sons, Chichester, EN.

Grime, J.P., Hodgson, J.G., Hunt, R. 2007. Comparative plant ecology: a functional approach to common British species. 2nd ed. Castlepoint Press, UK.

Harrington, R., Anton, C., Dawson, T.P., Bello, F., Feld, C.K., Haslett, J.R., Kluvánkova-Oravská, T., Kontogianni, A., Lavorel, S., Luck, G.W., Rounsevell, M.D. a., Samways, M.J., Settele, J., Skourtos, M., Spangenberg, J.H., Vandewalle, M., Zobel, M., \& Harrison, P. a. 2010. Ecosystem services and biodiversity conservation: concepts and a glossary. Biodiversity and Conservation 19: $2773-2790$.

Hodgson, J.G., Wilson, P.J., Hunt, R., Grime, J.P., Thompson, K. 1999. Allocating C-S-R plant functional types: a soft approach to a hard problem. Oikos 85: 282-294.

Hooper, D. U., Solan, M., Symstad, A., Diaz, S., Gessner, M. O., Buchmann, N., ... \& Roy, J. 2002. Species diversity, functional diversity and ecosystem functioning. Biodiversity and Ecosystem Functioning: Syntheses and Perspectives, 17, 195-208. Oxford University Press, UK.

Houston J. A. 2008. Management of Natura 2000 habitats. 2190 Humid dune slacks. European Commission.

Kadereit, G., Ackerly, D., \& Pirie, M.D. 2012. A broader model for $\mathrm{C}_{4}$ photosynthesis evolution in plants inferred from the goosefoot family (Chenopodiaceae s.s.). Proceedings. Biological sciences / The Royal Society 279: 3304-11.

Kattge, J., Díaz, S., Lavorel, S., Prentice, I.C., Leadley, P., Bönisch, G., Garnier, E., Westoby, M., Reich, P.B., Wright, I.J., Cornelissen, J.H.C., Violle, C., Harrison, S.P., Van BODEGOM, P.M., (...) \& Wirth, C. 2011. TRY - a global database of plant traits. Global Change Biology 17: 29052935.

Khan, M.A., \& Gul, B. 2002. Salt tolerent plant of coastal sabkhat of pakistan. In Barth \& Böer (eds.), 
Chapter 1: Introduction |

Sabkha ecosystems, pp. 123-139. Kluwer Academic Publishers, Netherlands.

Klotz, S., Kühn, I., Durka, W. (eds.) 2002. BIOLFLOR - Eine Datenbank zu biologisch-ökologischen Merkmalen der Gefäßpflanzen in Deutschland. - Schriftenreihe für Vegetationskunde 38. Bundesamt für Naturschutz. Bonn.

Kooyman, R., \& Rossetto, M. 2008. Definition of plant functional groups for informing implementation scenarios in resource-limited multi-species recovery planning. Biodiversity and Conservation 17: 2917-2937.

Lavorel, S., \& Garnier, E. 2002. Predicting changes in community composition and ecosystem functioning from plant traits : revisiting the Holy Grail. Functional Ecology 16: 545-556.

Lebrija-Trejos, E., Perez-Garcia, E.A., Meave, J.A., Bongers, F., \& Poorter, L. 2010. Functional traits and environmental filtering drive community assembly in a species-rich tropical system. Ecology 91: 386-398.

Léonard J. 1981-89. Contribution à l'étude de la flore et de la végétation des déserts d'Iran 9: 1-124. Meise, Jard. Bot. Nat. Belgique.

Lepš, J., \& de Bello, F. 2008. Instructions for calculating indices of Functional Diversity with the file “ FunctDiv . xls ." 481-501.

Lepš, J., de Bello, F., Lavorel, S., \& Berman, S. 2006. Quantifying and interpreting functional diversity of natural communities : practical considerations matter. Preslia 78: 481-501.

Lienau C. 1989. Griechenland. Geographie eines Staates der Europäischen Südperipherie. Wissenschaftliche Buchgesellschaft, Darmstadt, Germany.

Littmann, T., \& Veste, M. 2005. Modelling spatial patterns of vegetation in desert sand dunes. Forestry Studies in China 7: 24-28.

Lundgren, M.R., Christin, P.A., Escobar, E.G., Ripley, B.S., Besnard, G., Long, C.M., Hattersley, P.W., Ellis, R.P., Leegood, R.C., \& Osborne, C.P. 2016. Evolutionary implications of C3-C4 intermediates in the grass Alloteropsis semialata. Plant, Cell and Environment 39: 1874-1885.

Lundgren, M.R., Osborne, C.P., \& Christin, P.A. 2014. Deconstructing Kranz anatomy to understand C4 evolution. Journal of experimental botany 65: 3357-3369.

Mahdavi, P., \& Bergmeier, E. 2016. Plant functional traits and diversity in sand dune ecosystems across different biogeographic regions. Acta Oecologica 74: 37-45.

Mahdavi, P.M., Isermann, M. \& Bergmeier, E. 2017. Sand habitats across biogeographical regions at species, community and functional level. Phytocoenologia. In print. 
Maire, V., Gross, N., Börger, L., Proulx, R., Wirth, C., Pontes, L., Soussana, J.-F., \& Louault, F. 2012. Habitat filtering and niche differentiation jointly explain species relative abundance within grassland communities along fertility and disturbance gradients. New Phytologist 497-509.

Manafzadeh, S., Salvo, G., \& Conti, E. 2014. A tale of migrations from east to west: the IranoTuranian floristic region as a source of Mediterranean xerophytes (M. Ebach, Ed.). Journal of Biogeography 41: 366-379.

Manafzadeh, S., Staedler, Y.M., \& Conti, E. 2016. Visions of the past and dreams of the future in the Orient: The Irano-Turanian region from classical botany to evolutionary studies. Biological Reviews 9:.

Martinez, M.L., Hesp, P., \& Gallego-Fernandez, J.B. 2013. Ecology, Planning and Management of Urban Forests. Berlin.

Mason, N.W.H., \& De Bello, F. 2013. Functional diversity: A tool for answering challenging ecological questions. Journal of Vegetation Science 24: 777-780.

Mason, N.W.H., De Bello, F., Mouillot, D., Pavoine, S., \& Dray, S. 2013. A guide for using functional diversity indices to reveal changes in assembly processes along ecological gradients. Journal of Vegetation Science 24: 794-806.

Maun, A. 1998. Adaptations of plants to burial in coastal sand dunes. Canadian Journal of Botany 76: 713-738.

Maun, A.M. 2009. The biology of Coastal Sand Dunes. Oxford University press.

McGill, B.J., Enquist, B.J., Weiher, E., \& Westoby, M. 2006. Rebuilding community ecology from functional traits. Trends in Ecology and Evolution 21: 178-185.

Médail, F., \& Quézel, P. 1999. Biodiversity Hotspots in the Mediterranean Basin: Setting global conservation priorities. Conservation Biology 13: 1510-1513.

Mucina, L., Bültmann, H., Dierßen, K., Theurillat, J., Raus, T., Čarni, A., Šumberová, K., Willner, W., Dengler, J., García, R.G., Chytrý, M., Hájek, M., Di Pietro, R., Iakushenko, D., Pallas, J., Daniëls, F.J.A., Bergmeier, E., Santos Guerra, A., Ermakov, N., Valachovič, M., Schaminée, J.H.J., Lysenko, T., Didukh, Y.P., Pignatti, S., Rodwell, J.S., Capelo, J., Weber, H.E., Solomeshch, A., Dimopoulos, P., Aguiar, C., Hennekens, S.M., \& Tichý, L. 2016. Vegetation of Europe: hierarchical floristic classification system of vascular plant, bryophyte, lichen, and algal communities. Applied Vegetation Science 19: 3-264.

Mucina, L., \& O’Callaghan, M. 2003. Syntaxonomy and zonation patterns in coastal salt marshes of 
Chapter 1: Introduction |

the Uilkraals esturay, Western Cape (South Africa). Phytocoenologia 33: 309-334.

Muhaidat, R., Sage, R.F., \& Dengler, N.G. 2007. Diversity of Kranz anatomy and biochemistry in C4 eudicots. American Journal of Botany 94: 362-381.

Noble, I.R., \& Gitay, H. 1996. A functional classification for predicting the dynamics of landscapes. Journal of Vegetation Science 7: 329-336.

Osborne, C.P., \& Beerling, D.J. 2006. Nature's green revolution: the remarkable evolutionary rise of C4 plants. Philosophical transactions of the Royal Society of London. Series B, Biological sciences 361: 173-94.

Osborne, C.P., \& Freckleton, R.P. 2009. Ecological selection pressures for C4 photosynthesis in the grasses. Proceedings. Biological sciences / The Royal Society 276: 1753-60.

Pau, S., \& Still, C.J. 2014. Phenology and productivity of C3 and C4 Grasslands in Hawaii. PLoS ONE 9: $1-7$.

Pausas, J.G., Llovet, J., Rodrigo, a, \& Vallejo, R. 2008. Are wildfires a disaster in the Mediterranean basin? - A review. International Journal of Wildland Fire 17: 713-723.

Pennings, S.C., \& Bertness, M.D. 2001. Salt Marsh Communities. Marine Community Ecology

Pennings, S.C., \& Callaway, R.M. 1992. salt marsh plant zonation: The Relative Importance of Competition and Physical Factors. Ecology 73: 681-690.

Pérez-Harguindeguy, N., Díaz, S., Garnier, E., Lavorel, S., Poorter, H., Jaureguiberry, P., Bret-Harte, M.S., Cornwell, W.K., Craine, J.M., Gurvich, D.E., Urcelay, C., Veneklaas, E.J., Reich, P.B., Poorter, L., Wright, I.J., Ray, P., Enrico, L., Pausas, J.G., de Vos, A.C., Buchmann, N., Funes, G., Quétier, F., Hodgson, J.G., Thompson, K., Morgan, H.D., ter Steege, H., van der Heijden, M.G.A., Sack, L., Blonder, B., Poschlod, P., Vaieretti, M.V., Conti, G., Staver, A.C., Aquino, S., \& Cornelissen, J.H.C. 2013. New handbook for standardised measurement of plant functional traits worldwide. Australian Journal of Botany 61: 167-234.

Petchey, O.L. 2004. On the statistical significance of functional diversity effects. Functional Ecology 18: 297-303.

Petchey, O.L., \& Gaston, K.J. 2006. Functional diversity: back to basics and looking forward. Ecology letters 9: 741-58.

Petchey, O.L., Hector, A., \& Gaston, K.J. 2004. How do different measures of functional diversity perform? Ecology 85: 847-857. 
Pintó, J., Martí, C., \& Fraguell, R.M. 2014. Assessing Current Conditions of Coastal Dune Systems of Mediterranean Developed Shores. Journal of Coastal Research 296: 832-842.

Poschlod, P., Kleyer, M., Jackel, A.-K., Dannemann, A., \& Tackenberg, O. 2003. BIOPOP - A database of plant traits and internet application for nature conservation. Folia Geobotanica 38: 263-271.

Prisco, I., Carboni, M., \& Acosta, A.T.R. 2013. The Fate of Threatened Coastal Dune Habitats in Italy under Climate Change Scenarios. PLOS ONE 8:.

Provoost, S., Ampe, C., Bonte, D., Cosyns, E., \& Hoffmann, M. 2004. Ecology, management and monitoring of grey dunes in Flanders. Journal of Coastal Conservation 10: 33.

Quétier, F., Lavorel, S., Thuiller, W., \& Davies, I. 2007. Plant-trait-based modeling assessment of ecosystem-service sensitivity to land-use change. Ecological applications 17: 2377-86.

Redžić, S. 2007. Syntaxonomic diversity as an indicator of ecological diversity — case study Vranica Mts in the Central Bosnia. Biologia 62: 173-184.

Raunkiaer, C. 1934. The Life Forms of Plants and Statistical Plant Geography. Oxford University Press, Oxford, UK.

Rechinger, K.H. (ed) 1963-2012. Flora Iranica 1-178. Akademische Druck und Verlagsanstalt, Graz, Naturhistorisches Museum, Wien, AU.

Rennwald, E. (comp.) 2000. Verzeichnis und Rote Liste der Pflanzengesellschaften Deutschlands. Mit Datenservice auf CD-ROM. [Schriftenreihe für Vegetationskunde 35] Bundesamt für Naturschutz, Bonn - Bad Godesberg, DE.

Ricotta, C. 2005. A note on functional diversity measures. Basic and Applied Ecology 6: 479-486.

Sage, R.F. 2016. A portrait of the C4 photosynthetic family on the 50th anniversary of its discovery: Species number, evolutionary lineages, and Hall of Fame. Journal of Experimental Botany 67: 4039-4056.

Sage, R.F. 2005. Atmospheric $\mathrm{CO}_{2}$, Environmental Stress, and the Evolution of C4 Photosynthesis. In A History of Atmospheric $\mathrm{CO}_{2}$ and its Effects on Plants, Animals and Ecossistems, pp. 185-213. Springer, New York.

Sage, R.F. 2004. The evolution of C4 photosynthesis. New Phytologist 161: 341-370.

Sage, R.F., Christin, P.-A., \& Edwards, E.J. 2011. The C4 plant lineages of planet Earth. Journal of experimental botany 62: 3155-69. 
Chapter 1: Introduction |

Sage, R.F., \& Stata, M. 2015. Photosynthetic diversity meets biodiversity: The C4 plant example. Journal of Plant Physiology 172: 104-119.

Sasaki, T., Okubo, S., Okayasu, T., Jamsran, U., Ohkuro, T., \& Takeuchi, K. 2011. Indicator species and functional groups as predictors of proximity to ecological thresholds in Mongolian rangelands. Plant Ecology 212: 327-342.

Schaminée, J.H.J., Chytrý, M., Hennekens, S.M., et al. 2001. Development of vegetation syntaxa crosswalks to EUNIS habitat classification and related data sets. 1-135.

Schleuter, D.S., Daufresne, M.D., Massol, F.M., \& Argillier, C. 2010. A user's guide to functional diversity indices. Ecological monographs 80: 469-484.

Shannon, M.C. 1997. Adaptation of Plants to Salinity. Advances in Agronomy 60: 75-120.

Shipley, B., Vile, D., \& Garnier, E. 2006. From plant traits to plant communities: a statistical mechanistic approach to biodiversity. Science 314: 812-814.

Sundseth, K. 2009. Natura 2000 in the Atlantic Region. European Commission.

Sykora, K.V., Babalonas, D., \& Papastergiadou, E.S. 2003. Strandline and sand-dune vegetation of coasts of Greece and some other Aegean countries. Phytocoenologia 33: 409-446.

Taub, D.R. 2000. Climate and the U.S. Distribution of C4 Grass Subfamilies and Decarboxylation Variants of C4 Photosynthesis. American journal of botany 87: 1211-1215.

Taylor, S.H., Hulme, S.P., Rees, M., Ripley, B.S., Woodward, F.I., \& Osborne, C.P. 2010. Ecophysiological traits in $\mathrm{C} 3$ and $\mathrm{C} 4$ grasses: a phylogenetically controlled screening experiment. The New phytologist 185: 780-91.

Taylor, S.H., Ripley, B.S., Martin, T., De-Wet, L.A., Woodward, F.I., \& Osborne, C.P. 2014. Physiological advantages of $\mathrm{C} 4$ grasses in the field: A comparative experiment demonstrating the importance of drought. Global Change Biology 20: 1992-2003.

Taylor, S.H., Ripley, B.S., Woodward, F.I., \& Osborne, C.P. 2011. Drought limitation of photosynthesis differs between $\mathrm{C}_{3}$ and $\mathrm{C}_{4}$ grass species in a comparative experiment. Plant, cell \& environment 34: 65-75.

Violle, C., \& Jiang, L. 2009. Towards a trait-based quantification of species niche. Journal of Plant Ecology 2: 87-93.

Violle, C., Navas, M.-L., Vile, D., Kazakou, E., Fortunel, C., Hummel, I., \& Garnier, E. 2007. Let the concept of trait be functional! Oikos 116: 882-892. 
Voznesenskaya, E. V, Franceschi, V.R., Kiirats, O., Freitag, H., \& Edwards, G.E. 2001. Kranz anatomy is not essential for terrestrial C4 plant photosynthesis. Nature 414: 543-6.

Wright, I.J., Reich, P.B., Westoby, M., Ackerly, D.D., Baruch, Z., Bongers, F., Cavender-Bares, J., Chapin, T., Cornelissen, J.H.C., Diemer, M., Flexas, J., Garnier, E., Groom, P.K., Gulias, J., Hikosaka, K., Lamont, B.B., Lee, T., Lusk, C., Midgley, J.J., Navas, M.-L., Niinemets, Ü., Oleksyn, J., Osada, N., Poorter, H., Poot, P., Prior, L., Pyankov, V.I., Roumet, C., Thomas, S.C., Tjoelker, M.G., Veneklaas, E.J., \& Villar, R. 2004. The worldwide leaf economics spectrum. Nature 428: 821-827.

Zohary, M.1973. Geobotanical Foundations of the Middle East (Volume Iand II). Gustav Fischer Verlag, Stuttgart and Swets \& Zeitlinger, Amsterdam. 



\title{
Chapter 2
}

\section{Plant functional traits and diversity in sand dune ecosystems across different biogeographic regions}

\author{
P. Mahdavi, E. Bergmeier
}

Acta Oecologica 2016, 74: 37-45

http://dx.doi.org/10.1016/j.actao.2016.06.003 

Chapter 2: Plant functional traits in sand habitats |

\section{Abstract}

Plant species of a functional group respond similarly to environmental pressures and may be expected to act similarly on ecosystem processes and habitat properties. However, feasibility and applicability of functional groups in ecosystems across very different climatic regions have not yet been studied. In our approach we specified the functional groups in sand dune ecosystems of the Mediterranean, Hyrcanian and Irano-Turanian phytogeographic regions. We examined whether functional groups are more influenced by region or rather by habitat characteristics, and identified trait syndromes associated with common habitat types in sand dunes (mobile dunes, stabilized dunes, salt marshes, semi-wet sands, disturbed habitats). A database of 14 traits, 309 species and 314 relevés was examined and trait-species, trait-plot and species-plot matrices were built. Cluster analysis revealed similar plant functional groups in sand dune ecosystems across regions of very different species composition and climate. Specifically, our study showed that plant traits in sand dune ecosystems are grouped reflecting habitat affiliation rather than region and species pool. Environmental factors and constraints such as sand mobility, soil salinity, water availability, nutrient status and disturbance are more important for the occurrence and distribution of plant functional groups than regional belonging. Each habitat is shown to be equipped with specific functional groups and can be described by specific sets of traits. In restoration ecology the completeness of functional groups and traits in a site may serve as a guideline for maintaining or restoring the habitat.

Key words Climatic region; Cluster analysis; Coastal vegetation; Functional group; Habitat filter; Sand dunes

\section{Introduction}

Plant functional traits efficiently support the study of ecological systems as they allow to explain and generalize the ecosystem by making use of a limited number of functional groups rather than dealing with a large number of species (Díaz Barradas et al. 1999; Petchey 2004; Grime et al. 1997). Plant traits are useful to better understand plant and ecosystem function (Díaz and Cabido 2001; Helsen et al. 2012), for predicting vegetation changes (Lavorel and Garnier 2002) and for nature conservation (Poschlod et al. 2003; Kooyman and Rossetto 2008). They are particularly suitable for large-scale studies with different environmental conditions and for comparing regions with no or few species in common (Dupré and Ehrlén 2002; Díaz et al. 2007a; Tecco et al. 2010).

There is a wide range of studies using plant traits, dealing with different scales and numerous though nonexhaustive aspects of ecosystems, including land use (Díaz et al. 1999; Verheyen et al. 2003; Quétier et al. 2007), grazing (Klimešova et al. 2008; Díaz et al. 2007), fire (Lloret and Vilà 2003; Keeley et al. 2011), community dynamics (Pillar et al. 2013), climate change (Box 1996; Díaz and Cabido 1997), ecosystem 
Chapter 2: Plant functional traits in sand habitats |

services (de Bello et al. 2010) and phylogenetic structure and evolution (Kraft and Ackerly 2010; Pillar and Duarte 2010). Surprisingly few studies deal with functional groups without a priori classification. García-Mora et al. (1999) and Gallego-Fernández and Martínez (2011), for instance, defined functional groups in the coastal vegetation of SW Spain and Mexico, respectively, by using functional trait classification. Some researchers classified functional traits to study responses to disturbance (Lavorel et al. 1999) or for predicting the landscape dynamics (Noble and Gitay 1996) but functional classification did not become a common method in ecological studies. It has been argued that regionally defined functional groups might not function at global scale (Bugmann 1996). Noble and Gitay (1996) emphasized that functional classification is context-dependent and that universal functional groups may thus not be expected to occur. However, repeatable patterns of functional traits have been observed by some researchers (Wright et al. 2004; Sasaki et al. 2011) suggesting that functional groups may be applicable across regions. As functional groups comprise species with similar response to environmental pressures and similar effects on ecosystem processes (Díaz et al. 2001; Harrington et al. 2010), it may be expected that they are formed rather by habitat filters and niche similarities (Cornwell et al. 2006; Lebrija-Trejos et al. 2010; Maire et al. 2012) than by the biogeographic region. For instance, Díaz et al. (2001) showed that in two regions with different floras similar combinations of traits were associated with grazing. Such studies across different regions are needed to assess the feasibility and repeatability of functional groups.

Despite increasing attention to functional traits the knowledge of functional groups in specific ecosystems such as sand dunes is limited (García-Mora et al. 1999; Gallego-Fernández and Martínez 2011). Sand dunes, whether coastal or inland, are known as stress-prone habitats distributed worldwide in different climatic and biogeographic regions. Regardless of their differences in species composition, sand dune ecosystems are well adapted to cope with extreme stress such as of water deficiency, salinity and lack of soil and nutrients, and with disturbances through wind erosion and sand burial. The special adaptations of psammophytes to sand ecosystems are well reflected in their traits (Danin 1996; Maun 2009) and can be applied for studying dune vegetation at larger scale by defining groups of species with similar functionality for the ecosystem. Similar habitats and vegetation zonation in sand dunes all over the world (Doing 1985; Acosta 2009) suggest their azonal character. We chose sand dune ecosystems reflecting extreme environmental conditions to explore the adaptation strategies of plants in three regions very different in climate and phytogeography. We aim to identify functional groups of plants in various common habitats of sand dune ecosystems (both inland and coastal) via classification. Easily measurable traits have been selected to study the ecological response of plants to the environmental pressures in the habitats of the three regions. We specifically ask the following questions: Are there specific groups of species with similar traits in sand dune ecosystems across different biogeographical regions? Are plant functional groups more influenced by the habitat types and their local properties than by the climatic 
region in which the plants occur? If yes, which functional groups and trait syndromes (groups of consistently co-occurring traits that express adaptation to environmental characteristics) are associated with particular habitats in sand dune systems?

We hypothesized that there are widely applicable plant species traits determined by habitat characteristics and niches in sand dune ecosystems, and that the adaptive response of plants to the environment in a certain habitat is similar across biogeographical regions.

\section{Study area}

Sand dune ecosystems in three regions have been studied: Mediterranean, Hyrcanian, and Irano-Turanian (Fig. 1). The regions are very different in climate, phytogeography and species composition but are all furnished with a similar set of psammophytic habitat types.

Mediterranean region: NE Greece, ca. $300 \mathrm{~km}$ along the North Aegean coast from south of Katerini $\left(40^{\circ}\right.$ $\left.09^{\prime} \mathrm{N}, 22^{\circ} 33^{\prime} \mathrm{E}\right)$ via Thessaloniki eastward to Porto Lagos $\left(40^{\circ} 54^{\prime} \mathrm{N}, 25^{\circ} 23^{\prime} \mathrm{E}\right)$; The area is characterized by Mediterranean climate with hot, dry summers and wet and cool, but almost frost-free winters; mean monthly temperatures vary between $6{ }^{\circ} \mathrm{C}$ (January) and $25-27{ }^{\circ} \mathrm{C}$ (July); mean annual rainfall is 400-600 $\mathrm{mm}$ (Hellenic National Meteorological Service). The soil consists of fine quartz sands in dunes mixed with coarse sands and gravels in the stabilized dunes. Although not represented throughout, the vegetation zonation of sandy coasts includes drift lines (Euphorbion peplidis), mobile dunes (Ammophilion), stabilized hind dunes (Crucianellion maritimae) (Sýkora et al. 2003) and associated salt marshes (Salicornietalia fruticosae).

Hyrcanian region: NE Iran, SE Caspian Sea shore, Miankaleh Biosphere Reserve ( $36^{\circ} 48-55^{\prime} \mathrm{N}, 53^{\circ} 25^{\prime}-54^{\circ}$ $\left.02^{\prime} \mathrm{E}\right)$, with $50 \mathrm{~km}$ of semi-natural coastline, and two other sites westward along the Caspian Sea (36 $\left.49^{\prime} \mathrm{N}, 53^{\circ} 8^{\prime} \mathrm{E} \& 36^{\circ} 39^{\prime} \mathrm{N}, 52^{\circ} 22^{\prime} \mathrm{E}\right)$. The area has a warm humid climate with rainy summers and mild winters; mean annual temperature and rainfall are $17.9^{\circ} \mathrm{C}$ and $789 \mathrm{~mm}$, respectively (based on the nearest meteorological station in Sari). The coldest month is January with a mean temperature of $8.7^{\circ} \mathrm{C}$ and the warmest is August with $28{ }^{\circ} \mathrm{C}$. The soils and vegetation zonation resemble that of the Mediterranean coasts but the plant community composition differs. 
Chapter 2: Plant functional traits in sand habitats |

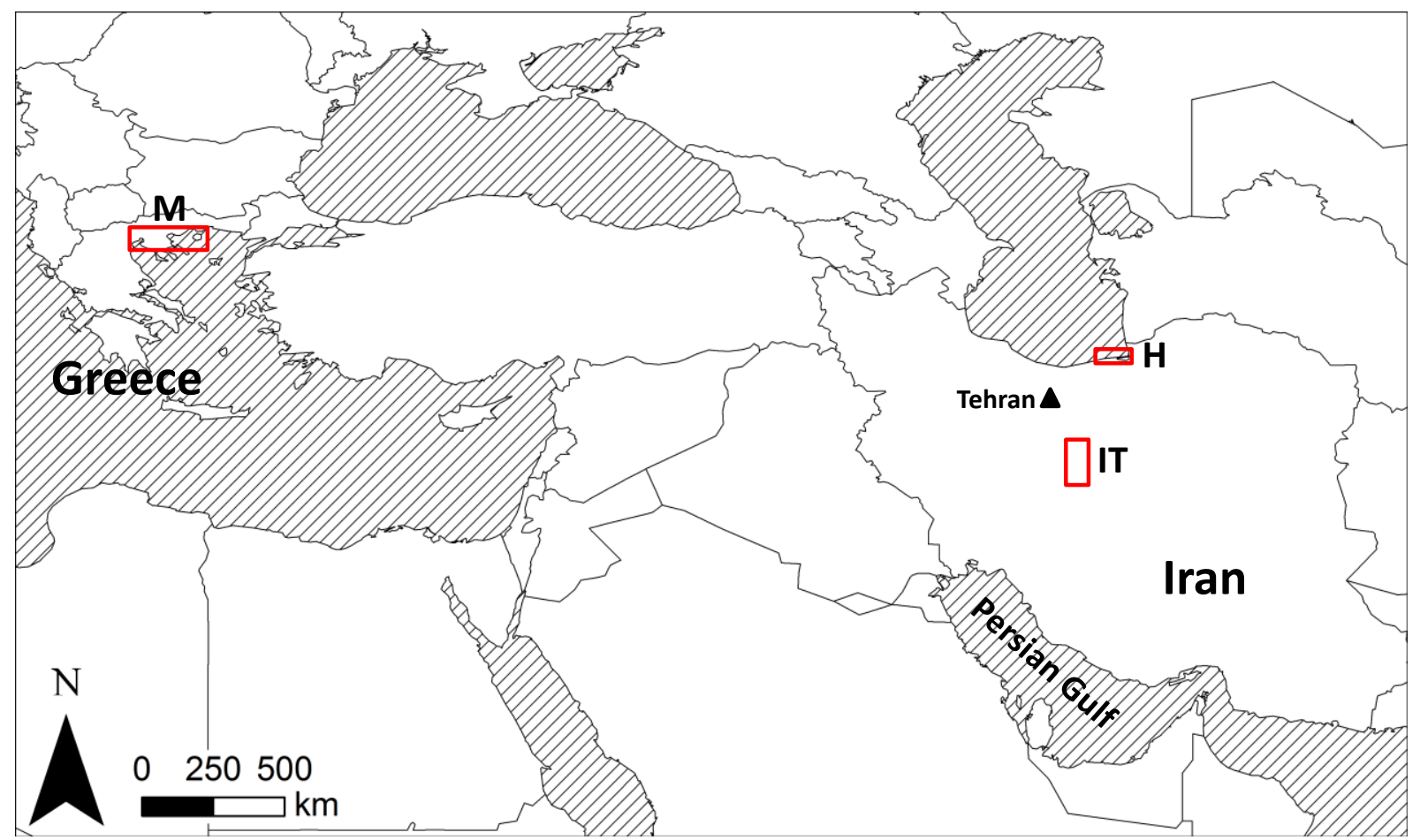

Fig. 1 Location of the study areas in the three climatic regions; M: Mediterranean (NE Greece); H: Hyrcanian (NE Iran); IT: Irano-Turanian (Central Iran)

Irano-Turanian region: Central Iran, southern shore of the Namak Lake (Daryacheh-ye Namak) in the Maranjab Desert (34 $\left.{ }^{\circ} 9-19^{\prime} \mathrm{N}, 51^{\circ} 30-56^{\prime} \mathrm{E}\right)$; large saline playa surrounded by halophytic communities and sand dunes. The area is characterized by continental climate with low precipitation, hot and dry summer and cold winter; annual temperature is $19^{\circ} \mathrm{C}$ and the annual precipitation is $136 \mathrm{~mm}$. Mean monthly temperatures vary between $5{ }^{\circ} \mathrm{C}$ (January) and $33{ }^{\circ} \mathrm{C}$ (July). The vegetation zonation differs from the coastal dunes in species composition and by the absence of drift lines.

\section{Methods}

\section{Data collection}

The field data were collected during the summers 2011 and 2012 in sand ecosystems of the Mediterranean, Hyrcanian and Irano-Turanian region. The vascular plant composition and coverabundance were sampled in plots of $25 \mathrm{~m}^{2}$. Five common and widespread habitat types in sand dunes were defined based on Devillers \& Devillers-Terschuren (1996; see also e.g. Doing 1985; Danin 1996; Maun 2009), comprising herbaceous and subshrub vegetation. We distinguished in each region (in brackets the corresponding EUNIS habitat type codes as in http://eunis.eea.europa.eu/habitats.jsp and plot numbers): 1. mobile dunes (B1.3, X35; 114 relevés); 2. stabilized dunes (B1.4; 46); 3. salt marshes (A2.5, D6.1; 95); 4. semi-wet sands (B1.8; 38) and 5. disturbed habitats (B1.1, H5.6; 21). In total, 314 relevés were collected: 161 relevés in the Mediterranean, 62 in the Hyrcanian and 91 in the Irano-Turanian region. Plant 
nomenclature follows Flora Iranica (Rechinger 1963-2012) for Iran, and Dimopoulos et al. (2013) for Greece.

Fourteen easily measurable categorical traits applicable for sand dune environments were chosen (Table 1). Categorical traits can be measured or obtained from the literature especially for areas without established trait databases. They also facilitate repeating and comparing the approach in other areas. The traits were selected from different parts of plants to better reflect the adaptive response patterns of species to the environment (Cornelissen et al. 2003). For standardization, the protocol for functional traits (PérezHarguindeguy et al. 2013) was followed. The observed species were assigned to the traits based on the given attributes in Table 1. Original trait information was obtained mainly from specimens collected and field observation, but also from floras (Rechinger 1963-2012) and other resources (especially for plant strategies and regenerative traits Grime 2001; Grime et al. 2007; Klotz et al. 2002).

\section{Data analysis}

In order to find the main functional groups (FG) of plant species, a trait database built of all species and trait variables was examined using cluster analysis (Ward's method with relative Euclidean distance; PCORD, McCune \& Mefford 1999). The cluster analysis was also run for each region separately to compare the resultant groups with those of the whole dataset (graphs not shown). The cluster cut level was determined manually so that each group was represented in each region, and that the resulting groups were interpretable and in line with the field observations.

As the three regions had only few species in common, a species-plot database would not be informative for comparison. Therefore, the trait-plot matrix was built by multiplying the trait-species matrix by the matrix of species-plot. The matrix calculation was done using R, package SYNCSA (Debastiani and Pillar 2012). The trait-plot matrix was then analyzed by means of Detrended Correspondence Analysis (DCA) using CANOCO 4.5 (ter Braak \& Šmilauer 2002) to understand the distribution of functional traits in sandy ecosystems. 
Chapter 2: Plant functional traits in sand habitats |

Table 1 List of plant functional traits and their attributes used in this study. Original trait data were obtained from specimens and field observation, complemented by data from floras and other literature resources.

\begin{tabular}{|c|c|}
\hline Functional traits & Attributes \\
\hline \multicolumn{2}{|l|}{ Vegetative traits } \\
\hline Life form & $\begin{array}{l}\text { annual; chamaephyte; hemicryptophyte (incl. } \\
\text { geophyte); phanerophyte }\end{array}$ \\
\hline Plant height & $\begin{array}{l}1=1-30 \mathrm{~cm} ; 2=31-60 \mathrm{~cm} ; 3=61-100 \mathrm{~cm} ; 4= \\
>1 \mathrm{~m}\end{array}$ \\
\hline Clonality & $0=$ no clonality $; 1=$ clonal plant \\
\hline Plant strategy type & $\begin{array}{l}\text { competitor (C); stress tolerant (S); ruderal (R); } \\
\text { intermediate strategies CS; CR; SR; CSR }\end{array}$ \\
\hline \multicolumn{2}{|l|}{ Regenerative traits } \\
\hline Dispersal mode & $\begin{array}{l}\text { anemochory; zoochory; no obvious dispersal } \\
\text { agent (probably autochory) }\end{array}$ \\
\hline Pollination mode & $\begin{array}{l}\text { anemophilous; entomophilous, zoophilous, } \\
\text { self-pollinated }\end{array}$ \\
\hline \multicolumn{2}{|l|}{ Leaf traits } \\
\hline Photosynthetic pathway & $0=\mathrm{C}_{3} ; 1=\mathrm{C}_{4}$ \\
\hline Leaf and/or stem succulence & $0=$ not succulent $; 1=$ succulent \\
\hline Reduced leaves & $\begin{array}{l}0=\text { no evidence of leaf reduction; } 1=\text { reduced } \\
\text { or no leaves }\end{array}$ \\
\hline Hairiness & $0=$ glabrous; $1=$ hairy \\
\hline Thorniness & $0=$ no thorns; $1=$ thorny \\
\hline Wax-coating & $0=$ no wax; $1=$ waxy \\
\hline \multicolumn{2}{|l|}{ Stem and root traits } \\
\hline $\begin{array}{l}\text { Carbohydrate storage in thickened root and } \\
\text { stem or long tap root }\end{array}$ & $\begin{array}{l}0=\text { no specialized storage organs; } 1= \\
\text { specialized organs }\end{array}$ \\
\hline Rhizomatous plant & $0=$ non-rhizomatous $; 1=$ rhizomatous \\
\hline
\end{tabular}

The main functional groups were correlated to the habitats by means of multivariate analysis. The speciesplot matrix was analyzed separately for each region using DCA. Rare species were downweighted. The functional groups (FG 1-7) obtained from the cluster analysis were used as external variable and plotted in the DCA scatter plot to illustrate which plant strategies were most successful in a given habitat type. To make a FG-plot matrix for a given region, the species list related to each FG and then to each plot was prepared. Further, the sum of the percentage cover values of species for a given FG was calculated and standardized to the relative values. The final matrix indicates the composition of FG for each plot in percentage values.

We used community-weighted trait mean values (Mason index), compatible with our categorical traits, to find out the trait syndromes in a given habitat. The trait value was weighted by the relative coverabundance of the species (in percentage) and the related index was calculated using FunctDiv (Lepš et al. 2006). 
Chapter 2: Plant functional traits in sand habitats |

\section{Results}

\section{Floristic diversity}

From a total of 309 species, 211 species were recorded in coastal sands of NE Greece, 66 species in NE Iran and 72 species in Central Iran. The species richness related to the same number of plots per region (62 randomly selected plots each) was more than two times higher in the Mediterranean area (173 species) than in the other two regions. The three areas had only few species in common, most of them distributed in the Mediterranean and the Hyrcanian areas (25 species), while only 9 species jointly occurred in the Mediterranean (M) and the Irano-Turanian (IT) and 6 species in the Hyrcanian and the Irano-Turanian areas. A high proportion of species in NE Greece belongs to the Mediterranean phytogeographical element (34\%), followed mainly by M-IT ( 16\%) and ES (Euro-Siberian)-M-IT ( 14\%). Species in N Iran comprise of different phytogeographical elements mainly recognized as IT ( 18\%), M-IT (13\%), ES-M-IT $(\sim 14 \%)$, ES-IT $(9 \%)$ and M ( $6 \%)$ elements. Proportion of the Mediterranean element in N Iran is notable. Species of the IT element are dominant in C Iran (41\%), followed with some distance by IT-SS (SaharoSindian) (17\%) and ES-M-IT ( 9\%). Cosmopolitan species contribute 13\% of the species recorded in sand dunes of $\mathrm{N}$ Iran, $9 \%$ in NE Greece and only 5\% in C Iran. Other elements have low percentages in each region. The species belong to 46 plant families and 201 genera. Approximately $52 \%$ of the species were annuals, $29 \%$ perennial graminoids, $11.6 \%$ woody plants, mostly low shrubs, and the rest were forbs.

\section{Cluster analysis of functional traits}

The psammophytes of the studied area were classified as seven main functional groups (FG; Table 2, Fig. 2), each consisting of plants with similar traits and thus similar functional potential for the ecosystem. At the first step of the cluster analysis, species were classed as two general plant groups of chiefly annuals and perennials, respectively. Perennials were then classified mainly based on stem and root traits into three FG: non-graminoid perennials, shrubs, and graminoids. The complete list of species per functional group is provided as supplementary material (Appendix B). 


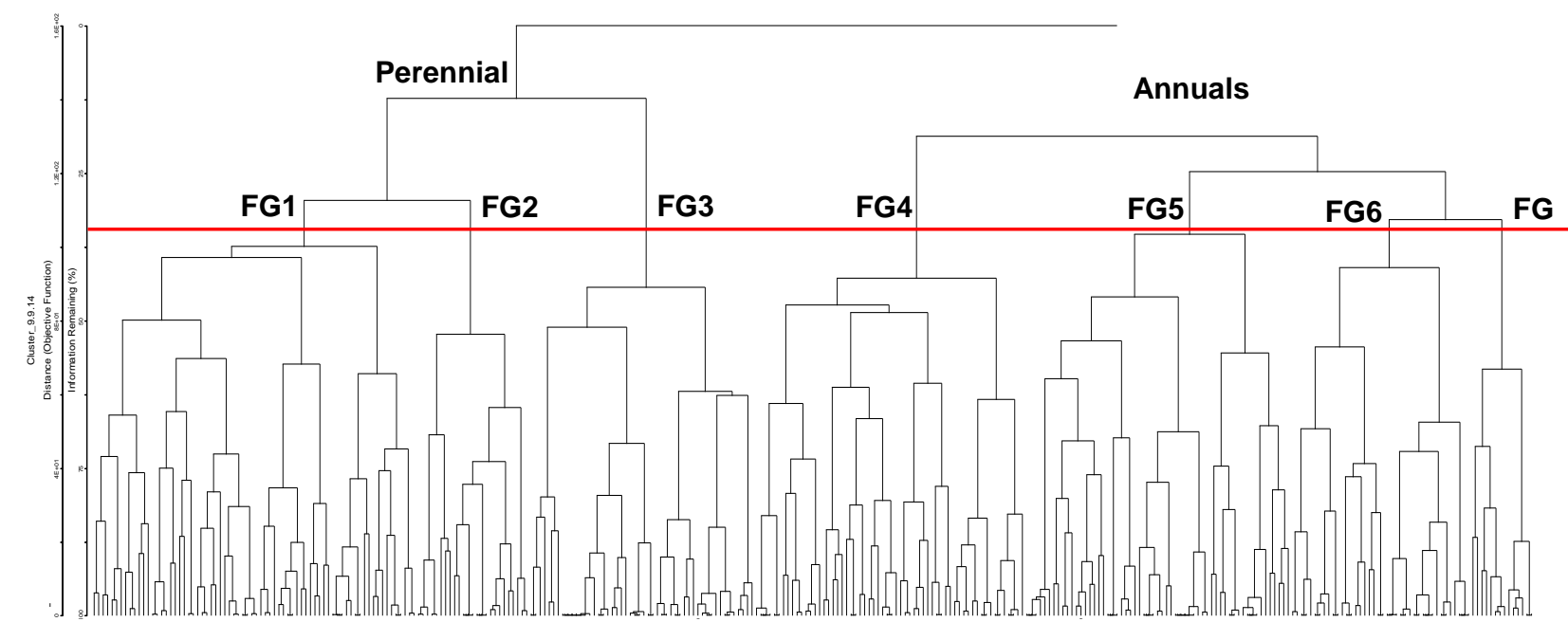

Fig. 2 Functional groups of species in sand dune habitats based on their trait similarities, using hierarchical cluster analysis (relative Euclidian distance, Ward's linkage method): FG1. Non-graminoid perennials; FG2. Shrubs; FG3. Perennial graminoids; FG4. Ruderals; FG5. Entomophilous therophytes; FG6. Short-lived grasses; FG7. Annual succulents. For the list of species in each group see Table S1.

FG1 comprises non-graminoid woody-based hemicryptophytes, geophytes, and dwarf shrubs, some of which cushion-shaped, generally with storage organs such as taproots, rhizomes, tubers or bulbs, or thickened stem bases. They are mainly stress-tolerant competitive species, many being more or less halotolerant, but only few are obligatory halophytes. A few sub-ruderal, disturbance-tolerant competitive grasses (Stipa capensis, Chrysopogon gryllus) and other competitors such as Cynanchum acutum, Alhagi maurorum and Eryngium campestre are also included (Table 2).

FG2 includes low to tall woody plants $(15 \mathrm{~cm}$ to $>2 \mathrm{~m}$ ) (Table 2). They tolerate dry conditions by reduced or succulent leaves, or stems covered by wax. Many are thorny. Succulents prevail in the salt marshes. They are adapted to the high salinity of the habitats by salt avoidance or salt tolerance.

FG3 comprises graminoids of mostly tall rhizomatous or more or less densely caespitose Poaceae, Cyperaceae and Juncaceae (Table 2). It includes two subgroups. While sedges and rushes occur chiefly in semi-wet or wet habitats, grasses prevail on dunes with mobile sands and other dry ground. They are clonal plants with carbohydrate stored in rhizomes or at the base of the tussocks. This strategy enables them to cope with perturbation and stress and to establish and persist in suitable patches. Wind dispersal facilitates the establishment of new colonies.

Annuals are classified into four FG (4-7, table 2), chiefly separated by habitat type and growth form.

FG4 includes almost exclusively annual or biennial herbs and grasses adapted to frequent disturbance. They are wind- or self-pollinated, and dispersed by wind. 
Table 2 Plant functional groups obtained from cluster analysis with their description and some dominant species occurring in each group. C: competitor; S: stress-tolerant; R: ruderal; hem.: hemicriptophyte; cham.: chamaephyte; M: Mediterranean; H: Hyrcanian; IT: Irano-Turanian.

\begin{tabular}{|c|c|c|}
\hline Functional group & Description & Characteristic species \\
\hline \multicolumn{3}{|l|}{ Perennials } \\
\hline $\begin{array}{l}\text { 1) Non-graminoid } \\
\text { perennials }\end{array}$ & $\begin{array}{l}\text { Sand dune/disturbed habitat, CS/CR } \\
\text { cushions with long tap root and/or woody } \\
\text { stem, non-graminoid hemicryptophytes or } \\
\text { chamaephytes, entomophilous pollination, } \\
\text { mostly dispersed by wind but partly without } \\
\text { obvious dispersal agent, frequently covered } \\
\text { by hair, } \mathrm{C}_{3} \text { photosynthesis }\end{array}$ & $\begin{array}{l}\text { M: Thymbra capitata, Artemisia campestris, } \\
\text { Silene otites, Hypericum olympicum, Fumana } \\
\text { procumbens, Scabiosa argentea, Centaurea } \\
\text { diffusa, Cynanchum acutum, Eryngium campestre } \\
\text { H: Argusia sibirica, Convolvulus cantabrica } \\
\text { IT: Smirnovia turkestana, Heliotropium } \\
\text { arguzioides, Alhagi maurorum }\end{array}$ \\
\hline 2) Shrubs & $\begin{array}{l}\text { Sand dune/salt marsh, CS } \\
\text { Small to } 3 \mathrm{~m} \text { tall shrubs, with salt and } \\
\text { drought adaptation, reduced leaves, succulent } \\
\text { stem or leaves, covered with wax, mostly } \\
\text { with anemophilous pollination and } \\
\text { anemochorous dispersal, including } \mathrm{C}_{4} \text { shrubs }\end{array}$ & $\begin{array}{l}\text { M: Atriplex portulacoides, Ephedra distachya, } \\
\text { Sarcocornia fruticosa, S. perennis, Halocnemum } \\
\text { strobilaceum } \\
\text { H: Ephedra procera, Lycium shawii } \\
\text { IT: Haloxylon ammodendron, Calligonum } \\
\text { crinitum, Ephedra strobilacea, Nitraria schoberi, } \\
\text { Salsola rosmarinus }\end{array}$ \\
\hline $\begin{array}{l}\text { 3) Graminoids } \\
\text { (grasses, sedges } \\
\text { and rushes) }\end{array}$ & $\begin{array}{l}\text { Sand dune/mesic habitat, CS/CR } \\
\text { species with rhizome, clonal growth, } \\
\text { anemophilous pollination, anemochorous } \\
\text { dispersal, mostly glabrous, including } \mathrm{C}_{4} \\
\text { grasses }\end{array}$ & $\begin{array}{l}\text { M: Ammophila arenaria, Cyperus capitatus, } \\
\text { Elytrigia juncea } \\
\text { H \& M: Saccharum ravennae, Juncus spp., } \\
\text { Scirpoides holoschoenus } \\
\text { IT: Stipagrostis spp., Centropodia forsskalii, } \\
\text { Cyperus eremicus }\end{array}$ \\
\hline \multicolumn{3}{|l|}{ Annuals } \\
\hline 4) Ruderals & $\begin{array}{l}\text { Disturbed habitats, } R \\
\text { Group of annuals with ruderal strategy, } \\
\text { pollinated by wind or insects, both } \\
\text { anemochory and zoochory is occurred, } C_{3} \\
\text { plants }\end{array}$ & $\begin{array}{l}\text { M: Bituminaria bituminosa, Eleusine indica, } \\
\text { Amaranthus albus, Echinochloa crus-galli, } \\
\text { Sonchus asper } \\
\text { H: Anagallis arvensis, Tragus racemosus, } \\
\text { Xanthium strumarium } \\
\text { IT: Chrozophora tinctoria, Centaurea } \\
\text { bruguierana }\end{array}$ \\
\hline $\begin{array}{l}\text { 5) Entomophilous } \\
\text { therophytes }\end{array}$ & $\begin{array}{l}\text { Mostly on fixed dunes, S/SR } \\
\text { Consist of small therophytes with } \\
\text { entomophilous pollination and anemochorous } \\
\text { dispersal, all with } \mathrm{C}_{3} \text { photosynthesis }\end{array}$ & $\begin{array}{l}\text { M: Jasione heldreichii, Malcolmia nana, } \\
\text { Matthiola tricuspidata, Nigella arvensis, } \\
\text { Medicago marina, Sideritis montana, } \\
\text { Pseudorlaya pumila, Medicago littoralis } \\
\text { H : Brassica tournefortii, Cakile maritime, } \\
\text { Daucus guttatus, Spergularia bocconei } \\
\text { IT: Acantolepis orientalis, Camelina rumelica, } \\
\text { Isatis minima, Malcolmia africana }\end{array}$ \\
\hline $\begin{array}{l}\text { 6) Short-lived } \\
\text { grasses }\end{array}$ & $\begin{array}{l}\text { Mostly on mobile dunes, } \mathrm{S} \\
\text { Small psammophyte mostly of grasses, with } \\
\text { anemophilous pollination and anemochorous } \\
\text { dispersal, usually covered by hair, } \mathrm{C}_{3} \\
\text { photosynthesis } \\
\text { Short life span }\end{array}$ & $\begin{array}{l}\text { M: Briza maxima, Bromus diandrus, Dasypyrum } \\
\text { villosum, Vulpia ciliata, Lagurus ovatus, } \\
\text { H : Bromus racemosus, Cutandia memphitica, } \\
\text { Parapholis incurva, Trisetaria linearis, } \\
\text { IT: Bromus scoparius, Cutandia dichotoma, } \\
\text { Schismus barbatus, } \\
\text { Non-grass spp.: Mollugo cerviana (M), Plantago } \\
\text { arenaria (M, H), Kochia stellaris (IT) }\end{array}$ \\
\hline $\begin{array}{l}\text { 7) Annual } \\
\text { succulents }\end{array}$ & $\begin{array}{l}\text { Salt marshes, S/SR } \\
\text { Salt tolerant anuuals, with succulent leaves } \\
\text { and/or stems, anemophilous pollination, } \\
\text { anemochory or hydrochory dispersal but } \\
\text { usually without obvious dispersal agent, } \\
\text { divided to } C_{3} \text { and } C_{4} \text { subgroups } \\
\end{array}$ & $\begin{array}{l}\text { M: Salicornia procumbens, Salsola soda, } S \text {. } \\
\text { tragus, Suaeda maritima, S. splendens } \\
\text { H : Salicornia iranica, Suaeda crassifolia } \\
\text { IT: Suaeda arcuata, Salsola kali }\end{array}$ \\
\hline
\end{tabular}


Chapter 2: Plant functional traits in sand habitats |

FG5 consists of non-ruderal therophytes and a few perennial herbs. They are commonly insect- or selfpollinated, and the dispersal strategy is mostly anemochorous or autochorous.

FG6 includes short-lived grasses, together with some dicots with inconspicuous flowers, with passive stress tolerance strategy, pollinated and dispersed by wind.

FG7 comprises annual succulents and sub-succulent plants inhabiting more or less disturbed sites in salt marshes or sometimes drift lines. They are tolerant to salt stress and frequently self- or wind-pollinated.

All seven functional groups are represented in all three studied biogeographic regions. Even after running the analysis separately for each region, the same functional groups were obtained (data not shown).

\section{Trait distribution across habitats}

The DCA of the species-plot matrix, run separately for each region, showed that the habitat types are well separated by species composition (Fig. 3a-c). The first axis in Fig. 3a (NE Greece) is interpreted as reflecting a gradient of water availability which is increasing towards salt marshes on the right side of the graph. Plants in coastal and inland dunes depend mostly on seasonal precipitation and salty or brackish temporarily available ground water resources while salt marshes are wet or semi-wet through surface waters over longer periods. The described pattern of trait distribution from NE Greece (Fig. 3a) was observed in the two other regions as well.

The DCA graphs also indicated the correlation of habitats with the functional groups. As shown in Fig. 3a, annual succulents (FG7) and shrubs (FG2) were more correlated with salt marshes while the FG3 subgroup of perennial grasses and the entomophilous therophytes (FG5) were chiefly associated with mobile dunes. Short-lived grasses (FG6) were found in stabilized dunes, non-graminoid perennials (FG1) in semi-wet habitats and annual ruderals (FG4) in disturbed habitats. The above mentioned correlation for NE Greece could be seen as well in the mobile dune, stabilized dune and salt marsh habitats of $\mathrm{N}$ and Central Iran (Fig. $3 b \&$ c). However, the low number of plots and therefore lower representativeness of species for semi-wet and disturbed habitats of those two regions resulted in a weak correlation of functional groups with these two habitats. 
Chapter 2: Plant functional traits in sand habitats |
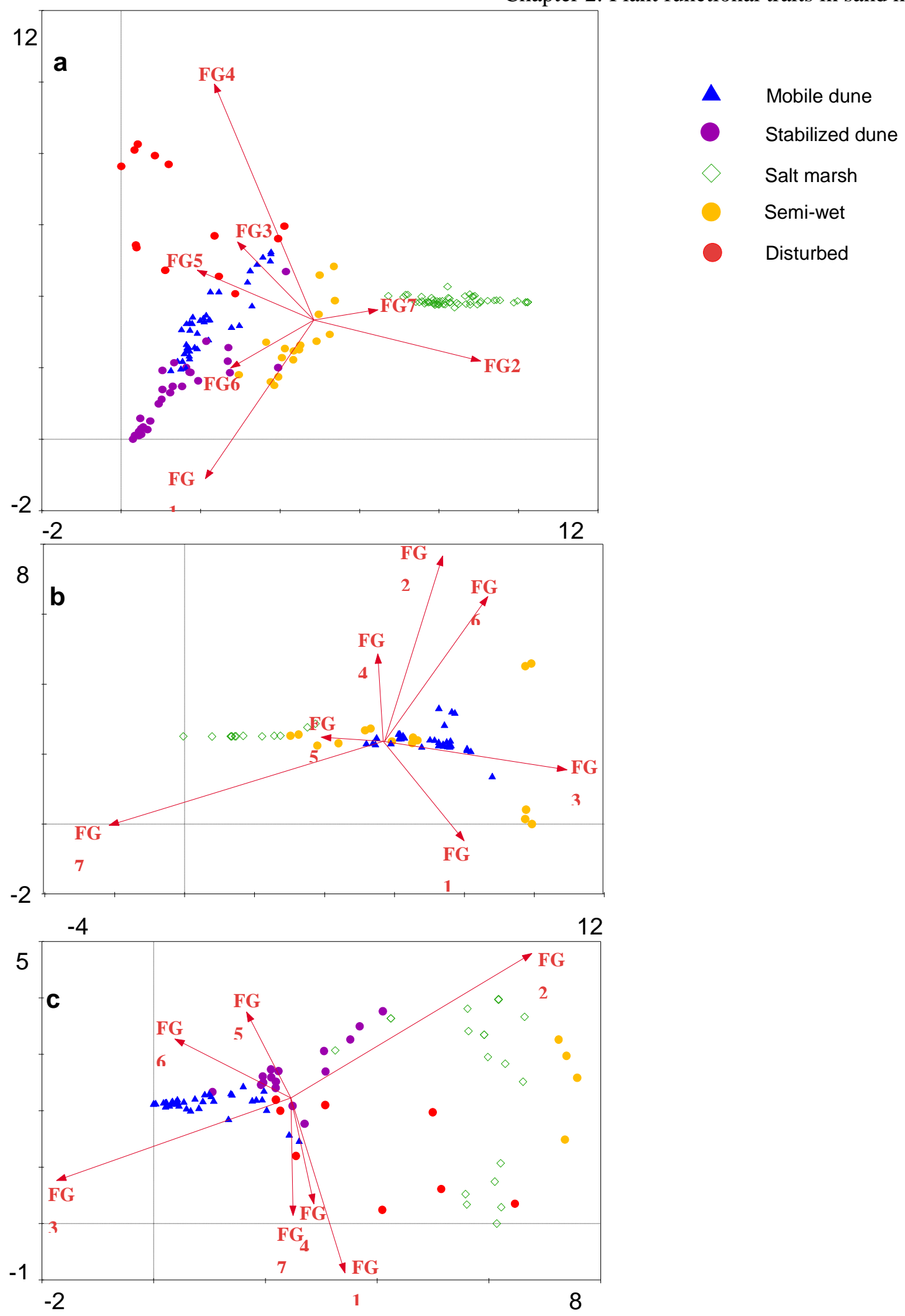

8

Fig. 3 Relation of habitats with functional groups (FG1-7) shown by DCA ordination of a species-plot matrix for each region: a. NE Greece; b. NE Iran; c. Central Iran. The eigenvalues for the first axes in a, b and c are 0.96 and the length of gradient for the first axis is 10.23 (a); 9.97 (b); 7.58 (c). Plots from disturbed habitats were excluded from analysis in NE Iran (b), as there were not enough representative plots for this type of habitat. 
Chapter 2: Plant functional traits in sand habitats |

\section{Trait distribution across regions}

In order to compare the three regions in terms of their functional traits and to see how the traits were distributed across the three regions, we analysed the trait-plot matrix for the whole data set. The DCA ordination diagram (Fig. 4) showed that the traits were grouped reflecting patterns of habitat affiliation rather than regional belonging.

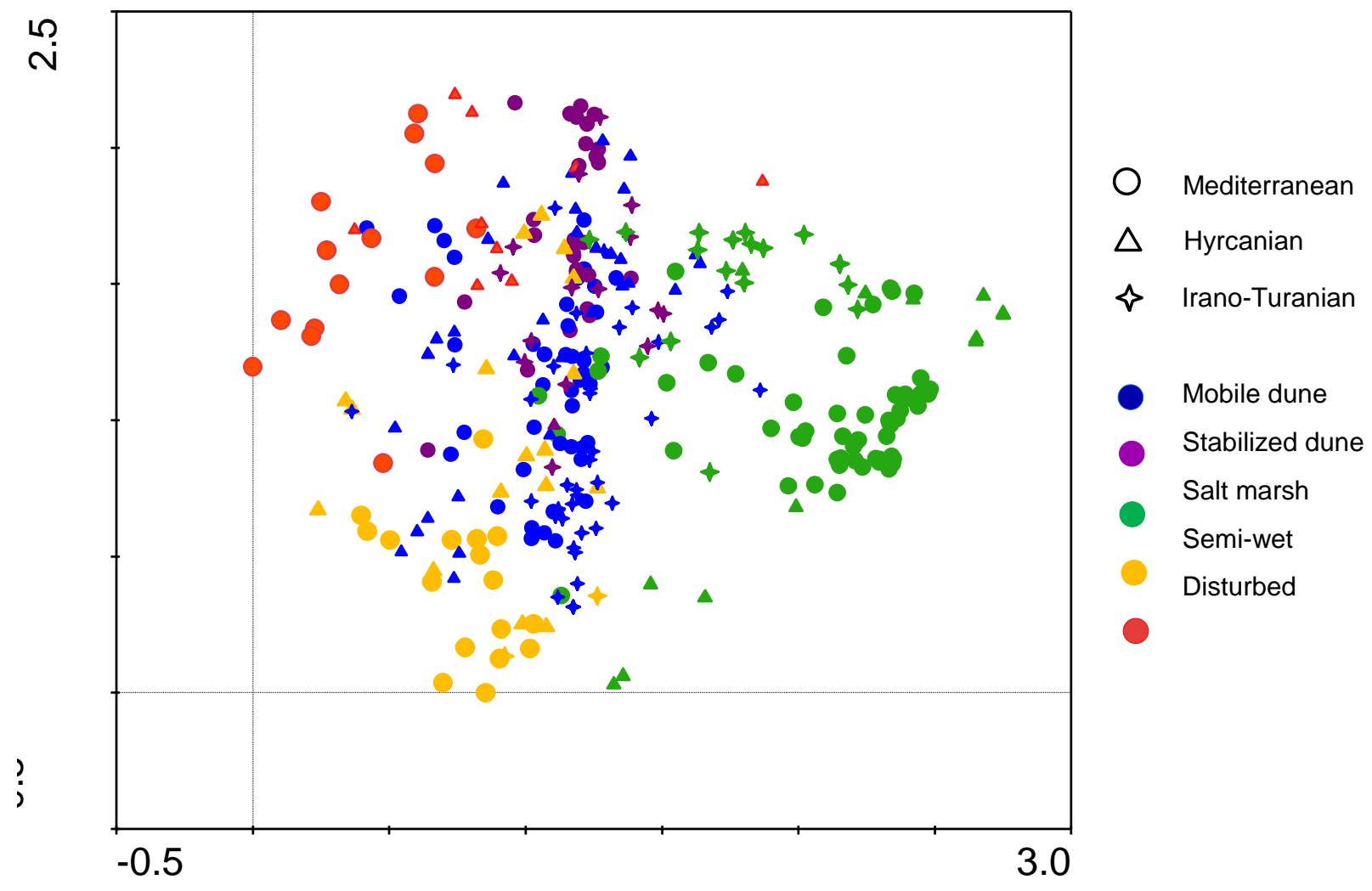

Fig. 4 DCA ordination of the trait-plot matrix for the combined data of three regions showing the distribution of traits among the sand dune habitats. Gradient length and eigenvalue for the first axis are 2.75 and 0.28 , respectively.

The Irano-Turanian region of Central Iran, for instance, is much dryer than N Iran and NE Greece (136 $\mathrm{mm}$ vs. 780 and $500 \mathrm{~mm}$, respectively) but the functional traits of the same habitats grouped together irrespective of their regions. Temperature differences among regions, both annual mean and mean minimum and maximum temperatures, were not reflected by functional trait distribution either. Species from a specific habitat have similar traits and function although they belong to different climatic regions with different species pools. For example, saltmarshes of the three regions grouped on the right side of the diagram as they share similar traits. The first axis can be interpreted as salinity gradient with a decreasing trend from right (salt marshes) to left. A gradient of dryness seems to rule the second axis with dryer habitats in the upper part and semi-wet to wet conditions in the lower part of the graph. Salt marshes have the highest salinity but moderate dryness. Wet sands and disturbed habitats which appear on opposite ends 
of the dryness gradient both display low salinity. The vegetation of stabilized dunes and mobile dunes show moderate salinity but the former which almost exclusively depends on precipitation water tends to be dryer than that of mobile dunes which is much more variable in terms of dryness.

\section{Community weighted trait means}

Community weighted trait mean values for the five studied habitats (table 3) indicated that dominant species in the mobile dunes tend to be taller than species in other habitat types and dispersed mostly by wind. Entomophilous species with dense indumentum and with thick storage stems or roots were found chiefly in stabilized dunes. Salt marshes were characterized by stress tolerant competitive species pollinated by wind. Succulent or reduced leaves covered by wax were common features among the species of this habitat. Semi-wet habitats were dominated by rhizomatous clonal plants pollinated mostly by wind. In disturbed habitats, ruderal competitors (CR strategy) were most prominent.

Table 3 Community weighted trait mean calculated for the five habitat types. For each trait, the highest value among the habitats is marked in bold. Abbreviation: Wind dis.: wind dispersal, Anem.: anemophilous, Ent.: entomophilous, CS: competitor-stress tolerant, CR: competitor-ruderal, Rhiz.: rhizomatous, TR/S: thick root/stem, RL: reduced leaves, SL: succulent leaves, Clon.: clonality, Cham.: chamaephyte, Hem.: hemicryptophyte

\begin{tabular}{|c|c|c|c|c|c|c|c|c|c|c|c|c|c|c|c|}
\hline & Wind dis. & Anem. & Ent. & CS & CR & Height & Rhiz. & TR/S & $\mathbf{R L}$ & SL & Hair & Wax & Clon. & Cham. & Hem. \\
\hline Mobile dune & 0.69 & 0.72 & 0.29 & 0.59 & 0.01 & 1.28 & 0.56 & 0.23 & 0.11 & 0.07 & 0.42 & 0.29 & 0.53 & 0.13 & 0.58 \\
\hline $\begin{array}{l}\text { Stabilized } \\
\text { dune }\end{array}$ & 0.54 & 0.48 & 0.52 & 0.36 & 0.03 & 0.89 & 0.26 & 0.50 & 0.18 & 0.05 & 0.62 & 0.29 & 0.28 & 0.33 & 0.30 \\
\hline Salt marsh & 0.63 & 0.88 & 0.23 & 0.69 & 0.00 & 0.96 & 0.37 & 0.45 & 0.51 & 0.75 & 0.11 & 0.83 & 0.58 & 0.56 & 0.18 \\
\hline Semi-wet & 0.59 & 0.85 & 0.22 & 0.44 & 0.04 & 1.05 & 0.73 & 0.19 & 0.16 & 0.01 & 0.38 & 0.37 & 0.77 & 0.02 & 0.75 \\
\hline Disturbed & 0.55 & 0.60 & 0.39 & 0.11 & 0.27 & 0.90 & 0.34 & 0.33 & 0.06 & 0.21 & 0.40 & 0.24 & 0.16 & 0.20 & 0.45 \\
\hline
\end{tabular}

\section{Discussion}

\section{Functional groups across different regions}

The results of our cluster analysis showed that similar plant functional groups of sand dune ecosystems occur across regions very different in species composition and climate. The plant functional groups obtained from cluster analysis (Fig. 2) are applicable for the three studied regions although the species numbers, floristic and plant community composition of the regions differ considerably. The functional groups represent various adaptive response types to stress-prone sand dune environments which are similarly realized in all study regions. For a given azonal ecosystem such as sand dunes it is shown that functional groups may be of universal relevance. Repeatability of the functional groups is an important issue if they are to be used in a global scale (Gitay \& Noble 1997). 
Chapter 2: Plant functional traits in sand habitats |

The groupings appear to be robust as we observed the same functional groups by running the analysis separately for each climatic region. By establishing functional groups with distinct combinations of traits for a given ecosystem complex or formation a comparison of ecological studies on a global scale is facilitated although they have few or no species in common. Duckworth et al. (2000) even argued for using plant functional groups as an alternative to species-based approaches in plant community research and biogeography. In our opinion, both approaches are supplementary.

In this study we showed that plant functional groups defined by using cluster analysis across different biogeographic regions are independent from the region. There are few studies using cluster analysis on functional traits in ecological studies (e.g. García-Mora et al. 1999). Alternatively, a priori groups, e.g. grasses, legumes and non-legume forbs, have been used (Lavorel et al. 1999; Lloret and Vilà 2003; McLaren 2006). Fry et al. (2014) discussed in detail the advantages of divisive hierarchical cluster analysis for creating functional groups in contrast to a priori grouping. They found strong similarity within groups generated from cluster analysis, indicating that each species was placed in the most appropriate group (Fry et al. 2014). It is also possible to assign new species to the existing functional groups by calculating the dissimilarity index and placing them alongside the group with the closest dissimilarity value (Fry et al. 2014). Functional groups derived from cluster analysis are more robust than a priori defined groups and therefore applicable to wider regions. In this study we used an agglomerative method for hierarchical clustering as a pre-defined number of groups was not desirable. We preferred to decide on the number of groups after the classification based on the interpretability of the clusters.

Danin (1996) classified psammophytes of inland desert dunes of Sinai and Negev using non-numerical methods. He described eight ecomorphological types of plants based on their root morphology and response to sand accumulation and deflation: A. perennial grasses requiring sand accumulation, B. species resistant to deep sand cover or removal (mostly shrubs), C. species of areas with moderate sand cover or removal, D. species actively resistant to sand deflation, E. passively resistant species to sand deflation, F. herbaceous perennials of stable sand sheets, G. shrubs of stable sand sheets, H. annuals. Our functional groups resulting from cluster analysis largely confirm but partly lump, partly split those plant types. Our FG3 (graminoids) is equivalent to group A; FG2 (shrubs) corresponds to groups B and G; and FG1 (nongraminoid perennials) includes groups C-F. Among the annuals we specified four different functional strategy groups (Table 2) rather than treating them as a single group. Our results, while found in wider regions and revealing more detailed groupings, are also generally congruent with three functional groups (winter annuals, perennials with spreading roots and plants capable of withstanding sand burial) derived from functional classification of coastal sand dunes of SW Spain (García-Mora et al. 1999). 
Chapter 2: Plant functional traits in sand habitats |

\section{Functional traits and habitat types}

We observed that the functional affiliation of sand dune species is shaped by the habitat rather than by the climatic region. In contrast, the regional species composition is more influenced by climate and phytogeographical conditions as each region has its own species pool with very few species shared among regions. The highest number of common species among regions (25) was observed between subhumid NE Greece (M) and humid N Iran (H) while arid C Iran has very few species in common with the other regions. Climate-related effects on the species composition and on plant meta-communities have been shown for coastal habitats of the Iberian peninsula (Jiménez-Alfaro et al. 2015). Our multivariate analysis of the trait-plot and species-plot matrices for all studied regions (Figs. 3 and 4) revealed that functional traits as well as species were grouped irrespective of the region but subject to the habitat type in which they occur. Pervasive environmental factors across the habitats appear to be salinity and (seasonal) dryness. Gallego-Fernández and Martínez (2011) showed that the functional groups of Mexican coastal dunes were independent from taxonomic and phylogenetic affiliations but related with environmental filters. The effect of habitat filtering implies similar ecological needs of co-occurring species (Cornwell et al. 2006). Habitat filters shape the distribution of functional traits (Cornwell and Ackerly 2009; Bermúdez and Retuerto 2013) as well as of species (e.g. Grubb 1985). Confirming those studies, our comparative analysis (both cluster analysis and ordination, Figs. 2 and 4) demonstrates that regional differences did not influence the functional groups and trait assemblages, suggesting independency from climatic conditions. The results did not reveal trait-based differences between inland dunes (Irano-Turanian) and coastal dunes (Mediterranean and Hyrcanian) either.

Furthermore, habitats are distinct in the combination and proportion of plant traits. We defined the trait syndromes for each habitat type indicating which combination of traits is most successful and dominant in a given habitat (Table 3). For instance, rhizomatous chamaephytes with CS strategy, pollinated and dispersed by wind, with reduced or succulent leaves, are prominent under salt and drought stress. Describing the functional dimension of a habitat may provide a better perspective for maintaining or restoring the habitat or ecosystem (Garnier and Navas 2011).

Even though our results highlight the applicability of functional groups across regions and its correlation with habitat characteristics, further studies are needed to better understand the triangle spanned by species, traits, and habitats. The challenge will be to define more refined functional groups representative of ecosystem function, vegetation structure and plant biodiversity, and to develop new tools for modeling. Reliable attribute data of many species as yet insufficiently known will have to be collected (Rusch et al. 2003; Boulangeat et al. 2012). The functional approach may also be used to evaluate the degree of anthropogenic impact and the effects of environmental stress on target functional groups of potentially endangered habitats, thereby identifying conservation priorities and suitable management. 
Chapter 2: Plant functional traits in sand habitats |

\section{Conclusions}

Our results provide further support to the idea that it is feasible to define and describe functional groups applicable at a large scale. Hierarchical cluster analysis is a simple but effective method for defining functional groups. Specifically, our study revealed that in sand dune ecosystems the plant traits are grouped reflecting habitat affiliation. Environmental factors and constraints such as sand mobility, soil salinity, water availability, nutrient status and disturbance are more important for the occurrence and distribution of plant functional groups than regional belonging, irrespective of the species pools. Even inland and littoral dunes do not seem to differ much regarding the observed patterns of traits and functional groups.

Furthermore, we defined trait syndromes in sand dune habitats by using community-weighted trait mean to perceive the effects of environmental stress on ecosystems caused by different disturbance regimes and land use (Hooper et al. 2002). Understanding the effect of environmental drivers on ecosystems is an important issue, both for preserving the present vegetation or for predictive purposes (e.g. consequences of global change). We consider functional traits as an effective tool for comparing ecosystem functions and processes, especially in regions with no or few species in common.

\section{Acknowledgment}

We would like to thank the Reinhold-und-Johanna-Tüxen-Stiftung for funding the field work in Iran for P.M. "Management Body of Delta Nestos, Lakes Vistonida-Ismarida" in Greece and departments of "Natural Resources of Esfahan" and "Nature Conservation of Mazandaran" in Iran are gratefully acknowledged for their help for visiting the areas. We would also like to thank Prof. Hossein Akhani for his support during the field work in Iran. We thank particularly Dr. Ioannis Tsiripidis and Dr. Georgios Fotiadis for their logistic support, discussions and their company at part of the field work in Greece. Advice by anonymous reviewers helped to improve an earlier version of the paper. 
Chapter 2: Plant functional traits in sand habitats |

\section{References}

Acosta , A., Carranza, M.L., Izzi, C.F. 2009. Are there habitats that contribute best to plant species diversity in coastal dunes? Biodiversity and Conservation 18:1087-1098.

Bermúdez, R., Retuerto, R. 2013. Living the difference: Alternative functional designs in five perennial herbs coexisting in a coastal dune environment. Functional Plant Biology 40: 1187-1198.

de Bello, F., Lavorel, S., Díaz, S., Harrington, R., Cornelissen, J.H.C., Bardgett, R.D., Berg, M.P., Cipriotti, P., Feld, C.K., Hering, D., Martins da Silva, P., Potts, S.G., Sandin, L., Sousa, J.P., Storkey, J., Wardle, D. a., \& Harrison, P. a. 2010. Towards an assessment of multiple ecosystem processes and services via functional traits. Biodiversity and Conservation 19: 2873-2893.

Boulangeat, I., Philippe, P., Abdulhak, S., Douzet, R., Garraud, L., Lavergne, S., Lavorel, S., Van Es, J., Vittoz, P., \& Thuiller, W. 2012. Improving plant functional groups for dynamic models of biodiversity: at the crossroads between functional and community ecology. Global change biology 18: 3464-3475.

Box, E.O. 1996. Plant functional types and climate at the global scale. Journal of Vegetation Science 7: 309-320.

Bugmann, H. 1996. Functional Types of Trees in Temperate and Boreal Forests: Classification and Testing. Journal of Vegetation Science 7: 359-370.

Cornelissen, J.H.C., Lavorel, S., Garnier, E., Díaz, S., Buchmann, N., Gurvich, D.E., Reich, P.B., Steege, H. Ter, Morgan, H.D., Heijden, M.G. a. Van Der, Pausas, J.G., \& Poorter, H. 2003. A handbook of protocols for standardised and easy measurement of plant functional traits worldwide. Australian Journal of Botany 51: 335-380.

Cornwell, W.K., \& Ackerly, D.D. 2009. Community assembly and shifts in plant trait distributions across an environmental gradient in coastal California. Ecological monographs 79: 109-126.

Cornwell, W.K., Schwilk, D.W., \& Ackerly, D.D. 2006. A trait-based test for habitat filtering: convex hull volume. Ecology 87: 1465-71.

Danin, A. 1996. Plants of Desert Dunes: adaptation of desert organisms. Springer, Berlin.

Debastiani, V.J., \& Pillar, V.D. 2012. SYNCSA--R tool for analysis of metacommunities based on functional traits and phylogeny of the community components. Bioinformatics 28: 2067-8.

Díaz Barradas, M.C., Zunzunegui, M., Tirado, R., Ain-Lhout, F., \& Novo, García, F. 1999. Plant functional types and ecosystem function in Mediterranean shrubland. Journal of Vegetation Science 
Chapter 2: Plant functional traits in sand habitats |

10: 709-716.

Díaz, S., \& Cabido, M. 1997. Plant functional types and ecosystem function in relation to global change. Journal of Vegetation Science 8: 463-474.

Díaz, S., \& Cabido, M. 2001. Vive la différence: plant functional diversity matters to ecosystem processes. Trends in ecology \& evolution 16: 646-655.

Díaz, S., Cabido, M., Zak, M., Martínez Carretero, E., \& Araníbar, J. 1999. Plant functional traits, ecosystem structure and land-use history along a climatic gradient in central-western Argentina. Journal of Vegetation Science 10: 651-660.

Díaz, S., Lavorel, S., McINTYRE, S., Falczuk, V., Casanoves, F., Milchunas, D.G., Skarpe, C., Rusch, G., Sternberg, M., Noy-Meir, I., Landsberg, J., Zhang, W., Clark, H., \& Campbell, B.D. 2007a. Plant trait responses to grazing? a global synthesis. Global Change Biology 13: 313-341.

Díaz, S., Lavorel, S., McINTYRE, S., et al. 2007. Plant trait responses to grazing ? a global synthesis. Global Change Biology 13:313-341.

Díaz, S., Noy-meir, I., \& Cabido, M. 2001. Can grazing response of herbaceous plants be predicted from simple vegetative traits? Journal of Applied Ecology 38: 497-508.

Dimopoulos, P., Raus, T., Bergmeier, E., Constantinidiset, T., et al. 2013. Vascular plants of Greece: an annotated checklist. Botanic Garden and Botanical Museum Berlin-Dahlem.

Doing, H. 1985. Coastal fore-dune zonation and succession in various parts of the world. Vegetatio 61: 65-75.

Duckworth, J.C., Kent, M., \& Ramsay, P.M. 2000. Plant functional types: an alternative to taxonomic plant community description in biogeography? Progress in Physical Geography 24: 515-542.

Dupré, C., Ehrlén, J. 2002. Habitat configuration, species traits and plant distributions. Journal of Ecology 90: 796-805.

Fry, E.L., Power, S. a., \& Manning, P. 2014. Trait-based classification and manipulation of plant functional groups for biodiversity-ecosystem function experiments (A. Prinzing, Ed.). Journal of Vegetation Science 25: 248-261.

Gallego-Fernández, J.B., \& Martínez, M.L. 2011. Environmental Filtering and Plant Functional Types on Mexican Foredunes along the Gulf of Mexico. Ecoscience 18: 52-62.

García-Mora, M.R., Gallego-Fernández, J.B., \& García-Novo, F. 1999. Plant functional types in coastal foredunes in relation to environmental stress and disturbance. Journal of Vegetation Science 10: 27- 
Chapter 2: Plant functional traits in sand habitats |

34.

Garnier, E., \& Navas, M.-L. 2012. A trait-based approach to comparative functional plant ecology: concepts, methods and applications for agroecology. A review.

Gitay H., and I. R. Noble. 1997. What are functional types and how should we seek them? Pages 3-19 in T. M. Smith, H. H. Shugart, and F. I. Woodward, editors. Plant functional types: their relevance to ecosystem properties and global change. Cambridge University Press, Cambridge, UK.

Grime, J.P. et al. 1997. Functional types: testing the concept in Northern England. In: Smith TM, Shugart HH, Woodward FI (eds.) Plant functional types: their relevance to ecosystem properties and global change. Cambridge University Press, Cambridge.

Grime, J.P. 2001. Plant Strategies, Vegetation Processes, and Ecosystem Properties. John Wiley \& Sons. Chichester, UK.

Grime, J.P., Hodgson, J.G., Hunt, R. 2007. Comparative plant ecology: a functional approach to common British species. 2nd ed. Castlepoint Press, UK.

Grubb, P.J. 1985. Plant populations and vegetation in relation to habitat, disturbance and competition: problems of generalization. In: White $\mathrm{J}$ (ed.) The population structure of vegetation. Springer, Netherlands.

Harrington, R., Anton, C., Dawson, T.P., Bello, F., Feld, C.K., Haslett, J.R., Kluvánkova-Oravská, T., Kontogianni, A., Lavorel, S., Luck, G.W., Rounsevell, M.D. a., Samways, M.J., Settele, J., Skourtos, M., Spangenberg, J.H., Vandewalle, M., Zobel, M., \& Harrison, P. a. 2010. Ecosystem services and biodiversity conservation: concepts and a glossary. Biodiversity and Conservation 19: 2773-2790.

Helsen, K., Hermy, M., Honnay, O. 2012. Trait but not species convergence during plant community assembly in restored semi-natural grasslands.Oikos 121: 2121-2130.

Hooper, D., Buchmann, N., Degrange, V., Diaz, S.M., Gessner, M., Grime, P. et al. 2002. Species diversity, functional diversity and ecosystem functioning. In: Biodiversity and Ecosystem Functioning, Loreau M., Naeem S. \& Inchausti P. (eds), Oxford University Press, Oxford.

Jiménez-Alfaro, B., Marcenò, C., Guarino, R., Chytrý, M. 2015. Regional metacommunities in two coastal systems: spatial structure and drivers of plant assemblages. Journal of Biogeography 42: $452-462$.

Keeley, J.E., Pausas, J.G., Rundel, P.W., Bond, W.J., \& Bradstock, R.A. 2011. Fire as an evolutionary pressure shaping plant traits. Trends in plant science 16: 406-411. 
Chapter 2: Plant functional traits in sand habitats |

Klimešová, J., Latzel, V., de Bello, F., \& van Groenendael, J. 2008. Plant functional traits in studies of vegetation changes in response to grazing and mowing: towards a use of more specific traits. Preslia 80: $245-253$.

Klotz, S., Kühn, I., Durka, W. (eds.) 2002. BIOLFLOR - Eine Datenbank zu biologisch-ökologischen Merkmalen der Gefäßpflanzen in Deutschland. - Schriftenreihe für Vegetationskunde 38. Bundesamt für Naturschutz. Bonn.

Kraft, N.J.B., \& Ackerly, D.D. 2010. Functional trait and phylogenetic tests of community assembly across spatial scales in an Amazonian forest. Ecological monographs 80: 401-422.

Kooyman, R., Rossetto, M. 2008. Definition of plant functional groups for informing implementation scenarios in resource-limited multi-species recovery planning. Biodiversity and Conservation 17: 2917-2937.

Lavorel, S., \& Garnier, E. 2002. Predicting changes in community composition and ecosystem functioning from plant traits : revisiting the Holy Grail. Functional Ecology 16: 545-556.

Lavorel, S., McIntyre, S., \& Grigulis, K. 1999. Plant response to disturbance in a Mediterranean grassland : How many functional groups? Journal of Vegetation Science 10: 661-672.

Lebrija-Trejos, E., Perez-Garcia, E.A., Meave, J.A., Bongers, F., Poorter, L. 2010. Functional traits and environmental filtering drive community assembly in a species-rich tropical system. Ecology 91 : 386-398.

Lepš, J., de Bello, F., Lavorel, S., \& Berman, S. 2006. Quantifying and interpreting functional diversity of natural communities : practical considerations matter. Preslia 78: 481-501.

Lloret, F., \& Vilà, M. 2003. Diversity patterns of plant functional types in relation to fire regime and previous land use in Mediterranean woodlands. Journal of Vegetation Science 14: 387-398.

Maire, V., Gross, N., Börger, L., Proulx, R., Wirth, C., Pontes, L., Soussana, J.-F., \& Louault, F. 2012. Habitat filtering and niche differentiation jointly explain species relative abundance within grassland communities along fertility and disturbance gradients. New Phytologist 497-509.

Maun, A.M. 2009. The biology of Coastal Sand Dunes. Oxford University press.

McCune, B., Mefford, M.J. 1999. PC-ORD. Multivariate analysis of ecological data. Version 4.25. MjM Software. Gleneden Beach, Oregon, USA.

McLaren, J.R. 2006. Effects of Plant Functional Groups on Vegetation Dynamics and Ecosystem Properties. Arctic 59: 449-452. 
Noble, I.R., \& Gitay, H. 1996. A functional classification for predicting the dynamics of landscapes. Journal of Vegetation Science 7: 329-336.

Pérez-Harguindeguy, N., Díaz, S., Garnier, E., Lavorel, S., Poorter, H., Jaureguiberry, P., Bret-Harte, M.S., Cornwell, W.K., Craine, J.M., Gurvich, D.E., Urcelay, C., Veneklaas, E.J., Reich, P.B., Poorter, L., Wright, I.J., Ray, P., Enrico, L., Pausas, J.G., de Vos, A.C., Buchmann, N., Funes, G., Quétier, F., Hodgson, J.G., Thompson, K., Morgan, H.D., ter Steege, H., van der Heijden, M.G.A., Sack, L., Blonder, B., Poschlod, P., Vaieretti, M.V., Conti, G., Staver, A.C., Aquino, S., \& Cornelissen, J.H.C. 2013. New handbook for standardised measurement of plant functional traits worldwide. Australian Journal of Botany 61: 167-234.

Petchey, O.L. 2004. On the statistical significance of functional diversity effects. Functional Ecology 18: 297-303.

Pillar, V.D., Blanco, C.C., Müller, S.C., Sosinski, E.E., Joner, F., \& Duarte, L.D.S. 2013. Functional redundancy and stability in plant communities (F. de Bello, Ed.). Journal of Vegetation Science 24: 963-974.

Pillar, V.D., \& Duarte, L.D.S. 2010. A framework for metacommunity analysis of phylogenetic structure. Ecology letters 13: 587-96.

Poschlod, P., Kleyer, M., Jackel, A., Dannemann, A., Tackenberg, O. 2003. BIOPOP - A database of plant traits and internet application for nature conservation. Folia Geobotanica 38: 263-271.

Quétier, F., Lavorel, S., Thuiller, W., Davies, I. 2007. Plant-trait-based modeling assessment of ecosystem-service sensitivity to land-use change. Ecological Applications 17: 2377-86.

Rechinger, K.H. (ed) 1963-2012 Flora Iranica 1-178. Akademische Druck und Verlagsanstalt, Graz, Naturhistorisches Museum, Verlag, Wien.

Rusch, G., Pausas, J., \& Lep̌̌, J. 2003. Plant functional types in relation to disturbance and land use. Journal of Vegetation Science 14: 307-310.

Sasaki, T., Okubo, S., Okayasu, T., Jamsran, U., Ohkuro, T., \& Takeuchi, K. 2011. Indicator species and functional groups as predictors of proximity to ecological thresholds in Mongolian rangelands. Plant Ecology 212: 327-342.

Sykora, K.V., Babalonas, D., \& Papastergiadou, E.S. 2003. Strandline and sand-dune vegetation of coasts of Greece and some other Aegean countries. Phytocoenologia 33: 409-446.

Tecco, P., Diaz, S., Cabido, M., Urcelay, C. 2010. Functional traits of alien plants across contrasting climatic and land-use regimes : do aliens join the locals or try harder than them ? Journal of Ecology 
Chapter 2: Plant functional traits in sand habitats |

98: 17-27.

ter Braak, C.J.F., Smilauer, P. 2002. CANOCO reference manual and CanoDraw for Windows user's guide: software for canonical community ordination (version 4.5). Ithaca: Microcomputer Power. Wageningen.

Verheyen, K., Honnay, O., Motzkin, G., Hermy, M., Foster, D.R. 2003. Response of forest plant species to land-use change: a life-history trait-based approach. Journal of Ecology 91: 563-577.

Wright, I.J., Reich, P.B., Westoby, M., Ackerly, D.D., Baruch, Z., Bongers, F., Cavender-Bares, J., Chapin, T., Cornelissen, J.H.C., Diemer, M., Flexas, J., Garnier, E., Groom, P.K., Gulias, J., Hikosaka, K., Lamont, B.B., Lee, T., Lusk, C., Midgley, J.J., Navas, M.-L., Niinemets, Ü., Oleksyn, J., Osada, N., Poorter, H., Poot, P., Prior, L., Pyankov, V.I., Roumet, C., Thomas, S.C., Tjoelker, M.G., Veneklaas, E.J., \& Villar, R. 2004. The worldwide leaf economics spectrum. Nature 428: $821-827$. 


\section{Chapter 3}

\section{Sand habitats across biogeographical regions at species, community and functional level}

Parastoo Mahdavi, Maike Isermann \& Erwin Bergmeier

Phytocoenologia 2017, 47: 139-165

DOI: $10.1127 /$ phyto/2017/0127 

Chapter 3: Similarity of sand habitats across biogeographical regions |

\section{Abstract}

Questions: To what extent does habitat similarity across different climatic regions support vegetation similarity at taxonomic, syntaxonomic and functional levels? Do different sand habitats share similarity patterns across regions? To what extent are sand habitats azonal with respect to taxonomic, syntaxonomic and functional similarity? What are the syntaxonomic and functional analogues? Study area: Coastal areas of N Germany, NE Greece, N Iran, and the Namak Lake shore in Central Iran. Methods: In four biogeographic regions (Atlantic, Mediterranean, Hyrcanian, Irano-Turanian) we collected 450 relevés representing four habitat types: drift lines, mobile dunes, stabilized dunes, and salt marshes. Plant communities were classified using TWINSPAN and assigned to syntaxa. High-rank syntaxa of each habitat were compared across four regions. Beta diversity was used to compare the species similarity between regions and habitats. We further compared trait-based functional groups across regions and habitats at the syntaxonomic level of class. Results: The floristic composition of sand habitats depended highly on the biogeographic region. At plant species and genus level, very low similarity was found between sand habitats of the same kind across regions as well as across habitats within a region. However, sand habitats of the same kind in different regions showed considerable functional similarity. Vegetation under particularly high stress, such as of salt marshes and drift lines, showed more syntaxonomic and functional similarities between regions than that of mobile and stabilized dunes, which was more determined by the regional species pool. Conclusions: The more stress-prone a habitat, the more is its vegetation habitat-related and the less dependent on the biogeographic region. All studied habitats are azonal but nuances are recognizable, and the concept of azonality is more generally applicable using functional traits as parameter. We further suggest using functional group proportions as a complementary tool to diagnostic species when comparing biogeographically distant, vicariant plant communities.

Keywords: Atlantic region; azonality; beta diversity; coastal vegetation; Irano-Turanian region; functional trait; Mediterranean region; saline habitat; salt marsh; sand dune; syntaxa

Nomenclature: Flora Iranica (Rechinger 1963-2012), Dimopoulos et al. (2013) and Florenliste von Deutschland (Buttler et al. 2015) for Iran, Greece and Germany, respectively; syntaxonomic nomenclature follows mainly Mucina et al. (2016) for Greece and Germany, and Asri (2003) for Iran.

Abbreviation: $\mathrm{FG}=$ Functional group

\section{Introduction}

Sand ecosystems, whether coastal or inland, comprise various habitat and vegetation types, showing a characteristic zonation, mainly differentiated by salt and drought gradients (Doing 1985; Carranza et al. 
Chapter 3: Similarity of sand habitats across biogeographical regions |

2008). Globally, they are frequently under pressure of urbanization, tourism and other human activities (Acosta et al. 2004; Pintó et al. 2014). This is a bothersome observation, not only for the sake of biodiversity but also as these ecosystems provide important services such as protection against wind erosion, waves and sea-level rise, water filtration and carbon sequestration, and they are indispensable breeding and nesting areas for wildlife (Defeo et al. 2009).

Sand ecosystems are specifically exposed to sand burial, salinity, dryness, lack of soil and nutrients, deflation, high wind speed, salt spray and inundation (Maun 2009). These factors shape a highly stressful environment for plants and greatly influence the vegetation composition and structure (Mucina et al. 2006). Specific plant communities are adapted to different habitats on sand, ranging from drift lines on the sea shores, mobile and stabilized dunes to salt marshes (Doing 1985; Acosta et al. 2007). Each zone provides specific environmental conditions inhabited and shaped by particular plant communities.

Drift lines are usually narrow linear habitats which occur just above the normal upper tidal limits along the sea shores. They may be rich in pebbles and shingle and have always high amounts of organic matter (Sýkora 2003, European Commission 2013). Inundation and frequent disturbances through high tides and storms are common features (Grime 2006). Drift lines are sparsely inhabited by annual nitrophilous plants resistant to high salt concentration and frequent disturbances.

Mobile dunes occur above the tidal limits and are characterized by sand accumulation and deflation. Sand burial and strong winds play an important role in shaping the vegetation. Sand accretion (to a certain extent) stimulates the growth of specific plants of mobile dunes, such as Ammophila arenaria, but also affects the composition and density of the vegetation by reducing and eliminating species intolerant to sand burial (Maun 1998).

Stabilized dunes are further developed dunes occupying the landward zone just behind the mobile dunes. Drought stress is the main environmental factor. Provoost et al. (2004) found that the surface temperature of stabilized dunes in Belgium could reach above $50{ }^{\circ} \mathrm{C}$. Due to the more stable soil conditions, the vegetation is denser if compared to seaward zones. The influence of salt is mainly by salt spray.

Salt marshes are permanently or temporarily wet littoral habitats. Coastal and desert salt marshes may be associated with tidal flats, salt pans or salt lakes. They accumulate organic matter and are temporarily inundated by salt or brackish water. High evaporation causes salt enrichment in both inland and coastal salt marshes (European Commission 2013). This highly stressful environment is generally species poor and the vegetation is sparse to rather close. Salinity gradients, flooding frequency and duration, soil texture and amounts of organic matter determine the vegetation structure and the productivity of the habitat (Pennings \& Callaway 1992; Mucina \& O’Callaghan 2003). 
Azonality refers to vegetation of similar appearance and composition regardless of the climatic region, and littoral sand ecosystems are generally considered azonal (Ellenberg \& Leuschner 2010). However, it has rarely been questioned whether there are nuances in the concept of azonality and on which vegetation parameters it may be based. We examined the effect of habitat and regionality on halophytic vegetation by comparing its similarities at the taxonomic, syntaxonomic and functional level. At each level we considered similarity in habitats of the same kind across regions as well as in a given region across different sand habitats. We specifically asked whether vegetation of the same habitat type is similar across different phytogeographical regions and which kinds of similarity are more pronounced. To what extent are sand habitats azonal regarding taxonomic (species and genera), syntaxonomic, and/or functional similarity? What are the taxonomic and functional analogues across climatic regions? Due to the omnipresent and prevalent salt effect on coastal and inland desert sand ecosystems, we hypothesized more syntaxonomic and functional similarity within a given habitat type across regions than among different habitat types within a given region. We tested four more or less saline habitat types (drift line, mobile dune, stabilized dune, and salt marsh) in four climatic and phytogeographic regions, ranging from the Atlantic coasts to Irano-Turanian salt lake shores.

\section{Study areas}

We studied coastal and halophytic inland sand ecosystems in four areas belonging to different climatic regions: Atlantic, Mediterranean, Hyrcanian and Irano-Turanian (Fig. 1).

In the Atlantic region, we analyzed data from coastal N Germany along the North Sea from the island of Borkum $\left(53^{\circ} 36^{\prime} \mathrm{N}, 6^{\circ} 43^{\prime} \mathrm{E}\right)$ eastward to the island of Fehmarn $\left(54^{\circ} 28^{\prime} \mathrm{N}, 11^{\circ} 08^{\prime} \mathrm{E}\right)$ at the Baltic Sea coast. Mean monthly temperatures for the North Sea (Island of Norderney) vary between $3{ }^{\circ} \mathrm{C}$ (January) and $18{ }^{\circ} \mathrm{C}$ (July). Mean annual rainfall is about $801 \mathrm{~mm}$, with higher amounts from July to December.

The study area in the Mediterranean region is located in NE Greece, ca. $300 \mathrm{~km}$ along the North Aegean coast from south of Katerini $\left(40^{\circ} 09^{\prime} \mathrm{N}, 22^{\circ} 33^{\prime} \mathrm{E}\right.$ ) eastward to Porto Lagos (40 $54^{\prime} \mathrm{N}, 25^{\circ} 23^{\prime} \mathrm{E}$ ). The area has hot and dry summers with wet, cool winters almost without frost. Mean monthly temperatures vary between $5-7^{\circ} \mathrm{C}$ (January) and $25^{-}-27^{\circ} \mathrm{C}$ (July). Mean annual rainfall is 400-600 $\mathrm{mm}$ (Lienau 1989).

In the Hyrcanian region, the SE Caspian Sea shore in N Iran was investigated, including the Miankaleh Biosphere Reserve $\left(36^{\circ} 48-55^{\prime} \mathrm{N}, 53^{\circ} 25^{\prime}-54^{\circ} 02^{\prime} \mathrm{E}\right)$ and two other sites ( $36^{\circ} 49^{\prime} \mathrm{N}, 53^{\circ} 8^{\prime} \mathrm{E}, 36^{\circ} 39^{\prime} \mathrm{N}$, $\left.52^{\circ} 22^{\prime} \mathrm{E}\right)$. The area is characterized by a warm humid climate with rainy summers and mild winters. The mean temperature of the coldest month (January) is $8.7^{\circ} \mathrm{C}$ and the warmest month is August with mean temperatures of ca. $28{ }^{\circ} \mathrm{C}$. The mean annual precipitation is $789 \mathrm{~mm}$ (based on the nearest meteorological station in Sari). 
Chapter 3: Similarity of sand habitats across biogeographical regions |

In the Irano-Turanian region, the southern shore of the Namak Lake (Daryacheh-ye Namak) in the

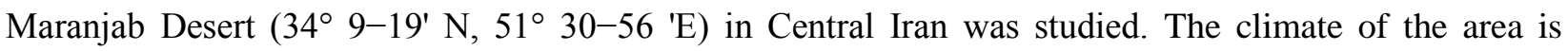
continental, characterized by low precipitation, hot and dry summers and cold winters. The mean temperature of the coldest month is ca. $5{ }^{\circ} \mathrm{C}$ (January) and that of the hottest month is $33{ }^{\circ} \mathrm{C}$ (July). The annual precipitation is $136 \mathrm{~mm}$.

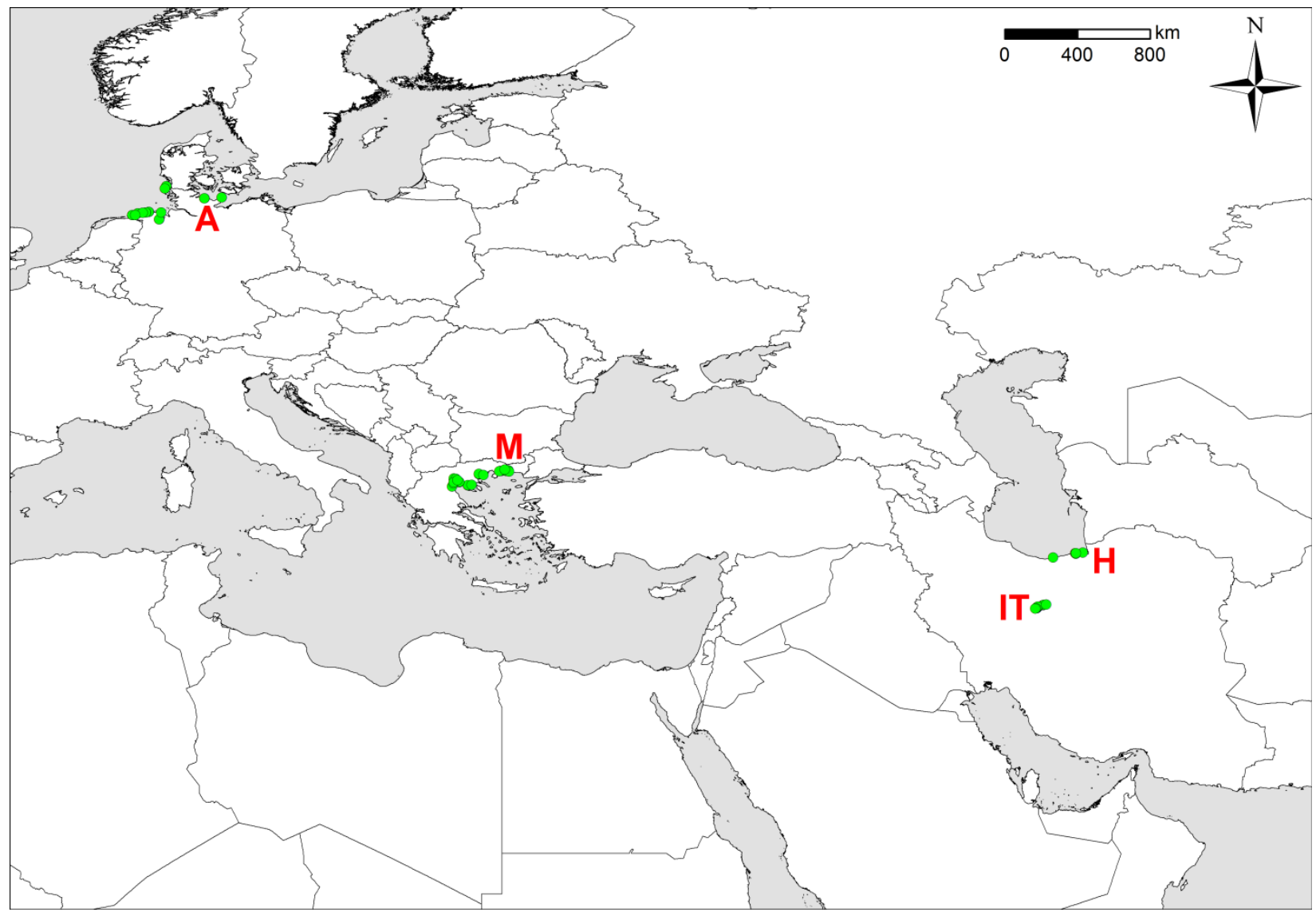

Fig.1 Location of the study areas in the four biogeographic regions: A: Atlantic (N Germany); M: Mediterranean (NE Greece); H: Hyrcanian (N Iran); IT: Irano-Turanian (Central Iran).

\section{Methods}

\section{Data collection}

The 319 vegetation plots in Iran and Greece were sampled in summer 2012 and 2013 using the BraunBlanquet cover/abundance scale (Dierschke 1994). The 131 plots from Germany were compiled randomly from the database of Coastal Vegetation Germany (GIVD code: EU-DE-035). A surface area of $25 \mathrm{~m}^{2}$ was applied for all plots. In each area, vascular plant cover-abundance data of four habitat types were collected: drift line, mobile dune, stabilized dune and salt marsh. 
Chapter 3: Similarity of sand habitats across biogeographical regions |

\section{Data analysis}

We classified the vegetation separately for each region in JUICE (Tichý 2002) using TWINSPAN (Hill $1979)$ with three pseudospecies cut levels $(0,2,5)$. Subsequent manual editing of the generated groups included the merging of small group of one to three relevés with the larger sister group, and the division of a large group into two TWINSPAN-generated subgroups. Synoptic tables were created, and diagnostic species determined, using percentage frequency (constancy) values. The plant communities of each habitat type were compared between regions by using higher-ranking syntaxa. When possible, vegetation groupings were assigned at the association level using the available literature.

In order to compare the taxonomic similarity (species and genera) between different regions and habitats, beta diversity was calculated using the Bray-Curtis index ( $\mathrm{R}$ software, package vegan; Oksanen et al. 2008). The gradient length in the first axis of a DCA (Detrended Correspondence Analysis) was used for estimating the vegetation dissimilarities over regions and habitats (CANOCO 4.5; ter Braak \& Šmilauer 2002). All species were included in both analyses. The average species richness per plot was calculated for each vegetation class.

Furthermore, the habitat-region effect on vegetation was compared at the functional level. We defined the dominant plant functional group (FG) in a given community by calculating the proportion of seven functional groups derived from a hierarchical cluster analysis of a species-traits matrix (for details see Mahdavi \& Bergmeier 2016): FG1, Non-graminoid perennials; FG2, Shrubs; FG3, Graminoid perennials; FG4, Annual ruderals; FG5, Entomophilous (insect-pollinated) annuals; FG6, Annual (non-ruderal) grasses; FG7, Annual succulents. The FG descriptors express the prevailing plant category (life form, growth form, strategy type) involved in the group (see Mahdavi \& Bergmeier 2016). The complete list of species for each functional group is provided in Appendix B.

The percentage cover of the above functional groups was calculated for each relevé, and the average value was reported for a given community. For this purpose, the Braun-Blanquet scale was transformed to median percentage values (Dierschke 1994: 158). In order to test that differences between proportions of functional groups of each community were significant and did not occur by chance, the non-parametric Kruskal-Wallis test was used (R package stats, Hollander and Wolfe 1973).

The assignment of vegetation groupings from Iran and Greece to plant associations proved to be difficult and is to some extent tentative, as the phytosociological knowledge for these countries is as yet far from sufficient. We referred to the informal 'community' to distinguish undescribed vegetation units from valid associations. In addition to the main cited syntaxonomic nomenclature, other publications were also considered (e.g. Pott 1992; Rennwald 2000; Rivas-Martinez 2001; Alaie 2001; Sciandrello \& Tomaselli 
Chapter 3: Similarity of sand habitats across biogeographical regions |

2013; Sýkora et al. 2013; Biondi et al. 2014). The authorities and the years of publication are provided in the syntaxonomic overview (Appendix C).

\section{Results}

\section{Taxonomic diversity and similarity}

Our beta diversity analysis confirmed that there is very low floristic similarity among regions and habitat types. Dissimilarity percentage values between habitats of the same kind in different regions (Table 1) varied from $85-100 \%$. Similar results were found between different habitat types of a given region (data not shown).

Habitats of the same kind in different regions share only four genera (Table 2). Cakile maritima (with various subspecies) and the species group of Salsola kali are common to drift lines in all regions while different species of Suaeda and Salicornia occur in salt marshes. The highest number of common genera (12) occurs on salt marshes of the Mediterranean (NE Greece) and Hyrcanian region (N Iran), including Aeluropus, Centaurium, Halocnemum, Hordeum, Juncus, Plantago, Polypogon, Puccinellia, Salicornia, Spergularia, Suaeda and Tripolium. Mobile dunes have the lowest number of common genera (0-2). Stabilized dunes of the Mediterranean and Hyrcanian region have 7 genera in common: Allium, Bromus, Corynephorus, Daucus, Ephedra, Plantago and Silene. Table 2 also shows that the Mediterranean region has a high number of taxa in common with the Hyrcanian and Atlantic regions. As revealed in the synoptic tables (Tables 3-6), there are almost no common species between different habitats of a given region. 
Chapter 3: Similarity of sand habitats across biogeographical regions |

Table 1. Bray-Curtis index of beta diversity for each habitat type over the four regions: C-Ir: Central Iran; Ge: $\mathrm{N}$ Germany; Gr: NE Greece; N-Ir: N Iran. Encountered species richness for each habitat is given in parentheses.

\begin{tabular}{|c|c|c|c|c|c|c|c|c|c|}
\hline \multicolumn{5}{|l|}{ Mobile dune (81) } & \multicolumn{5}{|c|}{ Stabilized dune (164) } \\
\hline & C-Ir & $\mathrm{Ge}$ & $\mathrm{Gr}$ & $\mathrm{N}-\mathrm{Ir}$ & & C-Ir & $\mathrm{Ge}$ & $\mathrm{Gr}$ & N-Ir \\
\hline C-Ir & 0.00 & & & & C-Ir & 0.00 & & & \\
\hline $\mathrm{Ge}$ & 1.00 & 0.00 & & & $\mathrm{Ge}$ & 1.00 & 0.00 & & \\
\hline $\mathrm{Gr}$ & 1.00 & 0.90 & 0.00 & & $\mathrm{Gr}$ & 0.98 & 0.95 & 0.00 & \\
\hline N-Ir & 0.99 & 1.00 & 0.96 & 0.00 & N-Ir & 0.99 & 1.00 & 0.88 & 0.00 \\
\hline Salt marsh (106) & & & & & Drift line (23) & & & & \\
\hline & C-Ir & $\mathrm{Ge}$ & Gr & $\mathrm{N}-\mathrm{Ir}$ & & $\mathrm{Ge}$ & $\mathrm{Gr}$ & N-Ir & \\
\hline C-Ir & 0.00 & & & & & & & & \\
\hline $\mathrm{Ge}$ & 1.00 & 0.00 & & & $\mathrm{Ge}$ & 0.00 & & & \\
\hline $\mathrm{Gr}$ & 0.98 & 0.98 & 0.00 & & $\mathrm{Gr}$ & 0.95 & 0.00 & & \\
\hline N-Ir & 0.91 & 0.95 & 0.88 & 0.00 & N-Ir & 0.85 & 0.92 & 0.00 & \\
\hline
\end{tabular}


Chapter 3: Similarity of sand habitats across biogeographical regions |

Table 2. Lists of genera (in bold) shared between regions followed by one or more species epithets separated by slash (/) for different regions. M: Mediterranean (NE Greece); H: Hyrcanian (N Iran); IT: Irano-Turanian (C Iran); A: Atlantic (N Germany).

\begin{tabular}{|c|c|c|c|c|c|c|}
\hline & $\mathbf{M} / \mathbf{H}$ & M/IT & M/A & H/IT & H/A & IT/A \\
\hline Drift line & $\begin{array}{l}\text { Cakile maritima, } \\
\text { Salsola (tragus/kali), } \\
\text { Xanthium strumarium }\end{array}$ & & $\begin{array}{l}\text { Cakile maritima, } \\
\text { Salsola (tragus/kali) }\end{array}$ & & $\begin{array}{l}\text { Cakile maritima, } \\
\text { Salsola kali }\end{array}$ & \\
\hline Mobile dune & Bromus diandrus & $\begin{array}{l}\text { Bromus } \\
\text { (diandrus/chrysop } \\
\text { ogon), Cyperus } \\
\text { (capitatus/ } \\
\text { eremicus) }\end{array}$ & $\begin{array}{l}\text { Ammophila arenaria, } \\
\text { Elymus (Elytrigia) } \\
\text { (bessarabica, } \\
\text { juncea/junceiformis), Leymus } \\
\text { (racemosus/arenarius) }\end{array}$ & \multicolumn{3}{|c|}{$\begin{array}{l}\text { Bromus } \\
\text { (diandrus/chrysopogon) } \\
\text { Cutandia } \\
\text { (memphitica/dichotoma) }\end{array}$} \\
\hline $\begin{array}{l}\text { Stabilized } \\
\text { dune }\end{array}$ & $\begin{array}{l}\text { Allium (guttatum, } \\
\text { sphaerocephalon/subn } \\
\text { otabile), Bromus } \\
\text { tectorum, } \\
\text { Corynephorus } \\
\text { divaricatus, Daucus } \\
\text { guttatus, Ephedra } \\
\text { (distachya/procera), } \\
\text { Plantago arenaria, } \\
\text { Silene conica } \\
\end{array}$ & $\begin{array}{l}\text { Ephedra } \\
\text { (distachyal } \\
\text { strobilacea), } \\
\text { Lomelosia } \\
\text { (argentea/olivieri) }\end{array}$ & $\begin{array}{l}\text { Agrostis (stolonifera, } \\
\text { capillaris), Corynephorus } \\
\text { (divaricatus/canescens), } \\
\text { Hypericum } \\
\text { (olympicum/perforatum), } \\
\text { Jasione (heldreichii, } \\
\text { montana), Plantago } \\
\text { (arenaria, lanceolata), } \\
\text { Trifolium (arvense, } \\
\text { echinatum/dubium) }\end{array}$ & \multicolumn{3}{|c|}{ Ephedra (procera/strobilacea) } \\
\hline Salt marsh & $\begin{array}{l}\text { Aeluropus littoralis, } \\
\text { Tripolium pannonicum, } \\
\text { Centaurium } \\
\text { (spicatum/erythraea), } \\
\text { Halocnemum } \\
\text { strobilaceum, Hordeum } \\
\text { marinum, Juncus } \\
\text { maritimus, Plantago } \\
\text { coronopus, Polypogon } \\
\text { maritimus, Puccinellia } \\
\text { (festuciformis, distans), } \\
\text { Salicornia } \\
\text { (procumbens/iranica), } \\
\text { Spergularia (media/ } \\
\text { marina), Suaeda } \\
\text { (maritima/crassifolia) }\end{array}$ & $\begin{array}{l}\text { Aeluropus } \\
\text { littoralis, } \\
\text { Polypogon } \\
\text { (maritimus, } \\
\text { monspeliensis), } \\
\text { Salicornia } \\
\text { (procumbens/pers } \\
\text { ica), } \\
\text { Salsola } \\
\text { (soda/rosmarinus) } \\
\text { Suaeda } \\
\text { (maritima/spp.) }\end{array}$ & $\begin{array}{l}\text { Tripolium pannonicum, } \\
\text { Atriplex } \\
\text { (portulacoides/prostrata), } \\
\text { Elytrigia } \\
\text { (elongata/pycnantha, repens), } \\
\text { Limonium } \\
\text { (bellidifolium/vulgare), } \\
\text { Plantago (coronopus, } \\
\text { maritima), } \\
\text { Puccinellia } \\
\text { (festuciformis/distans, } \\
\text { maritima), Salicornia } \\
\text { (procumbens/stricta, } \\
\text { europaea), } \\
\text { Spergularia (marina, media), } \\
\text { Suaeda maritima }\end{array}$ & $\begin{array}{l}\text { Aeluropus } \\
\text { (lagopoides, } \\
\text { littoralis), } \\
\text { Frankenia hirsuta, } \\
\text { Phragmites } \\
\text { australis, } \\
\text { Polypogon } \\
\text { (maritimus, } \\
\text { monspeliensis), } \\
\text { Salicornia } \\
\text { (iranica/persica), } \\
\text { Suaeda } \\
\text { (crassifolia/spp.) }\end{array}$ & $\begin{array}{l}\text { Tripolium } \\
\text { pannonicum, } \\
\text { Phragmites australis, } \\
\text { Plantago } \\
\text { (coronopus/maritima) } \\
\text { Puccinellia } \\
\text { (distans/distans, } \\
\text { maritima), } \\
\text { Salicornia } \\
\text { (iranica/stricta, } \\
\text { europaea), } \\
\text { Spergularia } \\
\text { (marina/marina, } \\
\text { media), } \\
\text { Suaeda } \\
\text { (crassifolia/maritima) }\end{array}$ & $\begin{array}{l}\text { Artemisia } \\
\text { (sieberi/maritima) } \\
\text { Phragmites } \\
\text { australis, } \\
\text { Salicornia } \\
\text { (persica/stricta, } \\
\text { europaea,), } \\
\text { Suaeda } \\
\text { (spp./maritima) }\end{array}$ \\
\hline
\end{tabular}




\section{Syntaxonomic diversity and similarity}

A long gradient (17.9) at the first DCA axis, considered as estimate of beta diversity, reveals the high compositional diversity in the vegetation between and within regions. While mobile dunes and stabilized dunes of different regions are separated, vegetation plots of salt marshes and drift lines from different regions are grouped together (Fig. 2). It may be assumed that the vegetation of drift lines and salt marshes is more associated with habitat features than with the other habitats studied in the same region. Mobile dunes and stabilized dunes, on the other hand, are more related to the regional species pool than to the same kind of habitats in other regions.

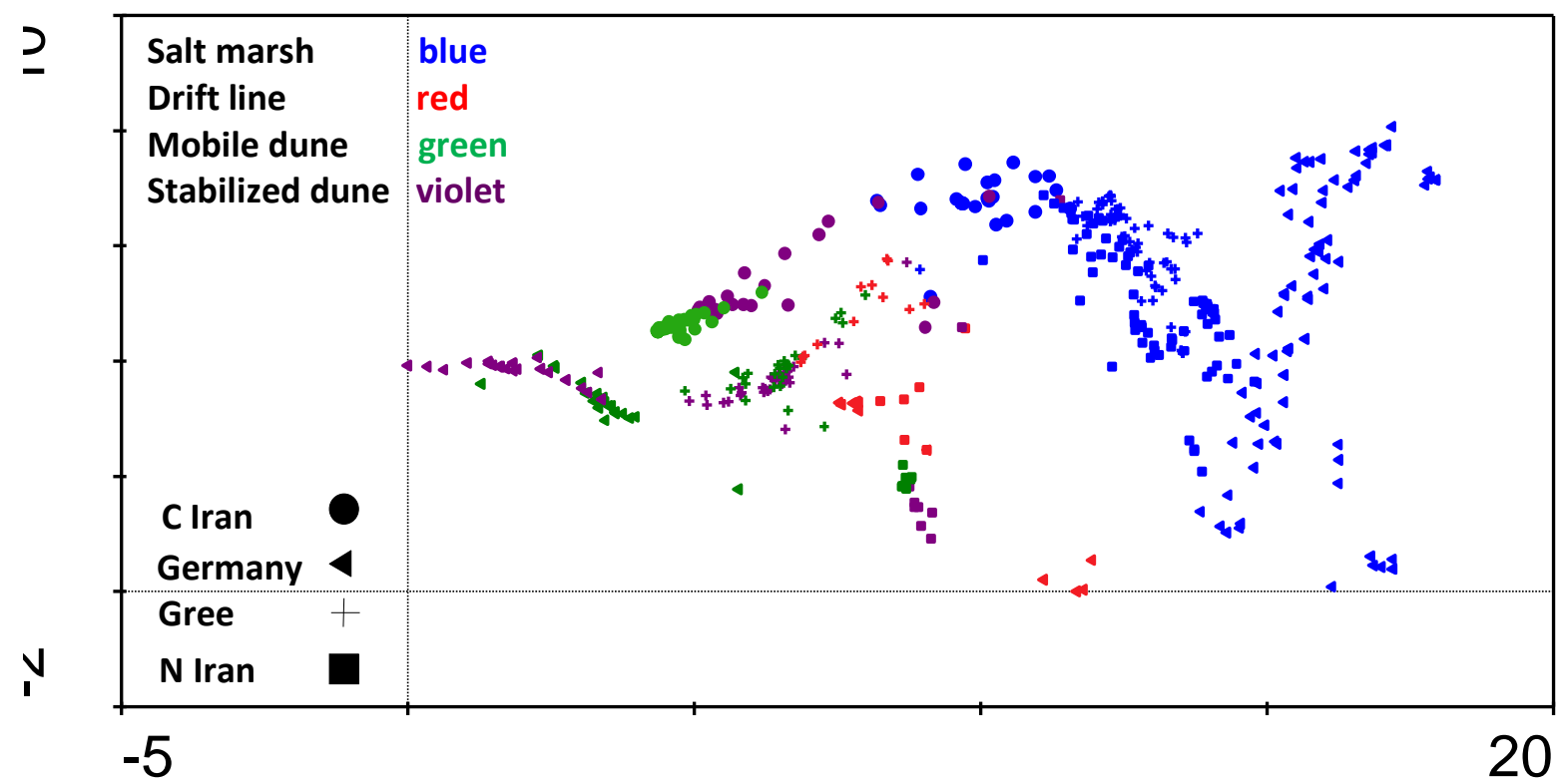

Fig. 2 DCA ordination of vegetation plots from four regions. Length of gradient in the first axis (17.9) is used as estimate of beta diversity to show the similarities between habitats of each region. Axis 2 gradient length is 8.1 . The eigenvalue for the $1^{\text {st }}$ and $2^{\text {nd }}$ axes are 0.98 and 0.89 respectively.

In N Germany we classified 12 associations from 7 classes and 11 alliances (Table 3), in NE Greece 12 associations of 6 classes and 8 alliances (Table 4), in N Iran 13 communities of 7 classes and 10 alliances (Table 5), and in central Iran 12 communities in 5 classes and 7 alliances (Table 6). A syntaxonomic comparison of the investigated areas regarding a given habitat type showed that salt marshes and drift lines have more syntaxa in common than mobile and stabilized dunes. In the following sections, we describe the syntaxonomic spectrum of each habitat across the regions. A detailed syntaxonomic overview is provided in Table 7. 
Chapter 3: Similarity of sand habitats across biogeographical regions |

Table 3 Synoptic table of coastal vegetation in N Germany. Related habitats, classes and dominant functional group in each class are provided. High species constancy values in one column (or two) relative to the other columns are framed. In contrast, relatively high but unframed constancy values indicate much lower cover-abundance of the species concerned. 'Other species' with constancy of $\leq 20 \%$ are listed at the bottom of the table. Detailed information on functional groups is given in Fig. 3. Habitat: d: drift line; f: stabilized (fixed) dune; m: mobile dune; s: salt marsh. Vegetation class: A: Cakiletea maritimae; B: Ammophiletea; C: Koelerio-Corynephoretea; D: TheroSalicornietea; E: Juncetea maritimi; F: Salicornietea fruticosae; G: Phragmito-Magnocaricetea.

\begin{tabular}{|c|c|c|c|c|c|c|c|c|c|c|c|c|}
\hline Community No. & 1 & 2 & 3 & 4 & 5 & 6 & 7 & 8 & 9 & 10 & 11 & 12 \\
\hline Number of relevés & 8 & 24 & 18 & 5 & 8 & 9 & 7 & 20 & 13 & 8 & 6 & 5 \\
\hline Habitat & $\mathrm{d}$ & $\mathrm{m}$ & $\mathrm{f}$ & $\mathrm{f}$ & $\mathrm{s}$ & $\mathrm{s}$ & $\mathrm{s}$ & $\mathrm{s}$ & $\mathrm{s}$ & $\mathrm{s}$ & $\mathrm{s}$ & $\mathrm{d}$ \\
\hline Functional group (FG) & $4 / 5$ & 3 & 3 & 3 & 7 & 3 & 7 & 2 & 3 & 7 & 3 & 4 \\
\hline Vegetation class & A & $\mathrm{B}$ & $\mathrm{C}$ & $\mathrm{C}$ & $\mathrm{D}$ & $\mathrm{E}$ & $\mathrm{D}$ & $\mathrm{F}$ & $\mathrm{E}$ & $\mathrm{D}$ & $\mathrm{G}$ & A \\
\hline \multicolumn{13}{|l|}{ Cakiletum maritimae } \\
\hline Cakile maritima & 100 & . & . & . & . & . & . & . & . & . & . & 20 \\
\hline Elymus junceiformis & 75 & 17 & 6 & . & . & . & . & . & . & . & . & ${ }^{\circ}$ \\
\hline Salsola kali & 25 & . & . & . & . & . & . & . & . & . & . & 20 \\
\hline \multicolumn{13}{|l|}{$\begin{array}{l}\text { Elymo arenarii- } \\
\text { Ammophiletum arenariae }\end{array}$} \\
\hline Ammophila arenaria & 13 & 100 & 67 & 20 & . & . & . & . & . & . & . & . \\
\hline Festuca rubra & . & 54 & 39 & 20 & . & . & . & . & 23 & . & . & . \\
\hline Sonchus arvensis & . & 29 & . & . & . & . & . & . & . & . & . & . \\
\hline Leymus arenarius & 13 & 25 & 11 & . & . & . & . & . & . & . & . & 20 \\
\hline Calammophila baltica & . & 33 & 34 & . & . & . & . & . & . & . & . & . \\
\hline \multicolumn{13}{|l|}{ Caricetum arenariae } \\
\hline Carex arenaria & . & 42 & 89 & 40 & . & . & . & . & . & . & . & . \\
\hline Corynephorus canescens & . & 21 & 78 & . & . & . & . & . & . & . & . & . \\
\hline Cerastium semidecandrum & . & 13 & 78 & 40 & . & . & . & . & . & . & . & . \\
\hline Viola canina & . & 4 & 28 & . & . & . & . & . & . & . & . & . \\
\hline Myosotis ramosissima & . & 8 & 22 & . & . & . & . & . & . & . & . & . \\
\hline Aira praecox & . & 8 & 83 & 100 & . & . & . & . & . & . & . & . \\
\hline \multicolumn{13}{|l|}{ Airo-Festucetum } \\
\hline Agrostis capillaris & . & . & 28 & 100 & . & . & . & . & . & . & . & . \\
\hline Rumex acetosella & . & . & 28 & 100 & . & . & . & . & . & . & . & . \\
\hline Festuca filiformis & . & . & . & 60 & . & . & . & . & . & . & . & . \\
\hline Hypochaeris radicata & . & 8 & 6 & 60 & . & . & . & . & . & . & . & . \\
\hline Achillea millefolium & . & . & . & 60 & . & . & . & . & . & . & . & . \\
\hline Aira caryophyllea & . & . & . & 60 & . & . & . & . & . & . & . & . \\
\hline Jasione montana s.l. & . & 4 & . & 60 & . & . & . & . & . & . & . & . \\
\hline Plantago lanceolata & . & . & . & 60 & . & . & . & . & . & . & . & . \\
\hline Trifolium dubium & . & . & . & 60 & . & . & . & . & . & . & . & . \\
\hline Sagina procumbens & . & . & 6 & 60 & . & . & . & . & . & . & . & . \\
\hline Holcus lanatus & . & 4 & 6 & 60 & . & . & . & . & . & . & . & . \\
\hline
\end{tabular}


Anthoxanthum odoratum

Trifolium pratense

Calluna vulgaris

Hypericum perforatum

Prunella vulgaris

Hieracium pilosella

Salicornietum strictae

Salicornia stricta

$100 \quad 22 \quad 43 \quad 5 \quad \cdot \quad 13$

Limonietum vulgaris

Limonium vulgare

Puccinellia maritima

Spergularia media

Suaedetum maritimae

Suaeda maritima

Spartina anglica

Halimionetum portulacoidis

Atriplex portulacoides

Tripolium pannonicum

60
40
40
40
40
40.

Juncetum gerardii

Juncus gerardii

Glaux maritima

Plantago maritima

Agrostis stolonifera s.1.

Festuca rubra s.l.

Carex extensa

Carex distans

Armeria maritima

Salicornietum ramosissimae

Salicornia europaea s.l.

Spergularia marina

Puccinellia distans

Bassia hirsuta

Scirpetum maritimi

Bolboschoenus maritimus

Phragmites australis

Atriplicetum littoralis

Atriplex prostrata s.l.

Atriplex littoralis

\begin{tabular}{l|l|llllll}
100 & & & 30 & 38 &. &. &. \\
13 & 100 & 43 & 80 & 23 & 38 &. & 20 \\
56 &. & 20 &. &. &. &.
\end{tabular}

$$
\begin{array}{ll|l|lllll}
63 & 89 & 100 & 75 & 8 & 25 & 17 & . \\
13 & 11 & 43 & 25 & . & 13 & . & .
\end{array}
$$

\begin{tabular}{lll|l|lllll}
$\cdot$ & 56 & 14 & 90 & 8 &. & 17 &. \\
13 & 22 & 43 & 85 & 46 & 25 &. & 20
\end{tabular}

Other species

Artemisia maritima

Triglochin maritimum

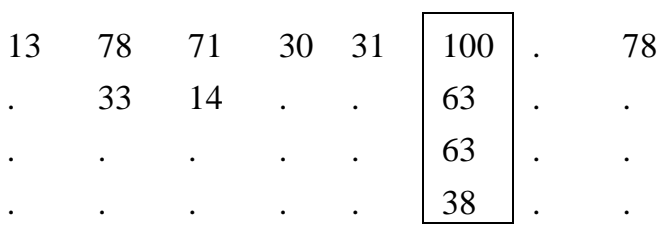

$\begin{array}{lllllll}44 & 14 & 40 & 8 & . & . & 40 \\ 44 & 14 & 40 & 46 & . & . & .\end{array}$


Chapter 3: Similarity of sand habitats across biogeographical regions |

Species with low constancy:

Arabidopsis thaliana 2: 4, 3: 6; Arenaria serpyllifolia 2: 17, 3: 17; Artemisia vulgaris 4: 40; Atrichum undulatum 4: 20; Atriplex glabriuscula 10: 13; Avenella flexuosa 2: 8; Bromus hordeaceus 3:17; Centaurium pulchellum 9: 8; Cerastium holosteoides 2: 4, 3: 6; Cirsium arvense 2: 8; Cirsium vulgare 2: 4, 3: 6; Cochlearia anglica 8: 5; Dactylis glomerata 4: 20; Draba verna 3: 17; Elymus athericus 2: 4, 8: 5, 12: 20; Elymus repens 3: 6, 4: 20; Epilobium angustifolium 2: 13, 3: 6; Erigeron canadensis 2: 4, 3: 6; Eryngium maritimum 2: 4; Festuca ovina s.1. 3: 17; Filago minima 2: 4; Galium aparine 2: 4; Galium mollugo agg. 2: 8; Galium verum 2: 4, 3: 22; Hieracium lachenalii 4: 20; Hieracium umbellatum 2: 13; Honckenya peploides 3: 17; Hypogymnia physodes 2: 4; Chenopodium glaucum 10: 13; Iris pseudacorus 3: 6; Juncus tenuis 4: 20; Koeleria arenaria 3: 6, 4: 20; Leontodon saxatilis 2: 4; Linaria vulgaris 2: 13; Lolium perenne 3: 11; Lophocolea bidentata 2: 4; Luzula campestris 3: 17; Odontites litoralis 9: 8; Oenothera ammophila 2: 17; Peltigera canina 3: 6; Plantago coronopus 3: 6; Plantago major s. intermedia 3: 6; Poa апnи 3: 17; Poa humilis 2: 4, 3: 11, 4: 20.; Poa pratensis 2: 4; Pohlia nutans 2: 4; Polypodium vulgare 2: 8; Potentilla anserina 9: 15, 11: 17, 12: 20; Radiola linoides 9: 8; Rhytidiadelphus squarrosus 2: 4, 3: 6; Rubus caesius 2: 8, 3: 11; Rumex acetosella s. acetosella 2: 4; Rumex crispus 2: 13; Sagina maritima 10: 13; Scleranthus perennis 4: 20; Scleropodium purum 3: 6; Sedum acre 2: 17, 3: 11; Senecio inaequidens 2: 4; Senecio jacobaea 2: 13; Senecio vernalis 3: 6; Senecio viscosus 2: 4; Senecio vulgaris 2: 17; Sonchus asper 2: 4; Spergularia media 9: 15; Stellaria graminea 2: 4, 4: 20; Taraxacum spp. 2: 4, 3: 23, 4: 20; Teesdalia nudicaulis 2: 4; Trifolium repens 3: 17, 9: 15; Tripleurospermum maritimum 5: 20; Tripleurospermum perforatum 10: 13; Urtica dioica 3: 6; Veronica arvensis 3: 6; Veronica officinalis 3: 6; Viola tricolor s. Curtisii 2: 13, 3: 17.

\section{Drift lines}

The habitat is characterized by plant communities of the Cakiletea maritimae (Table 3, comm. 1; Table 4, comm. 8; Table 5, comm. 11), assemblages of annual plants dependent on nutrient input chiefly from seaweed and other organic material washed ashore. It is a naturally disturbed habitat in narrow bands near the sea, often heavily impacted by garbage. This habitat is fragmented and widely destroyed through tourist activities and beach cleaning at the coasts of Iran, Greece and Germany. The communities of Cakile maritima in the Mediterranean, Atlantic and Hyrcanian coasts are given in Table 7.

\section{Mobile dunes}

Ammophila arenaria, eponymous species of the class Ammophiletea, is a common and dominant species with two vicariant subspecies on mobile dunes of the Mediterranean (Table 4, comm. 10) and Atlantic coasts (Table 3, comm. 2). The Ammophiletea appear to be absent from the Hyrcanian region, where the class is replaced by the Artemisietea lerchianae. The latter is dominated by Artemisia tschernieviana (Table 5, comm. 13). The Artemisietea lerchianae form an Aralo-Caspian group of sub-halophilous plant communities on sandy soils (Rodwell et al. 2002). Mobile inland dunes of the Irano-Turanian region are characterized by the Stipagrostietea pennatae, with plant communities and species composition very different from those of the other regions. This class comprises communities mostly dominated by grasses such as Stipagrostis pennata, S. karelinii, S. barbata and Centropodia forsskalii, and by Cyperus eremicus. The latter may be seen as a geographical analogue of Cyperus capitatus, which is common in the Mediterranean Ammophiletea vegetation. There are no considerable syntaxonomic similarities between regions in this habitat type (Table 7). Photos of the mobile dune habitats and the prevailing vegetation are shown in Fig. 3a-d. 

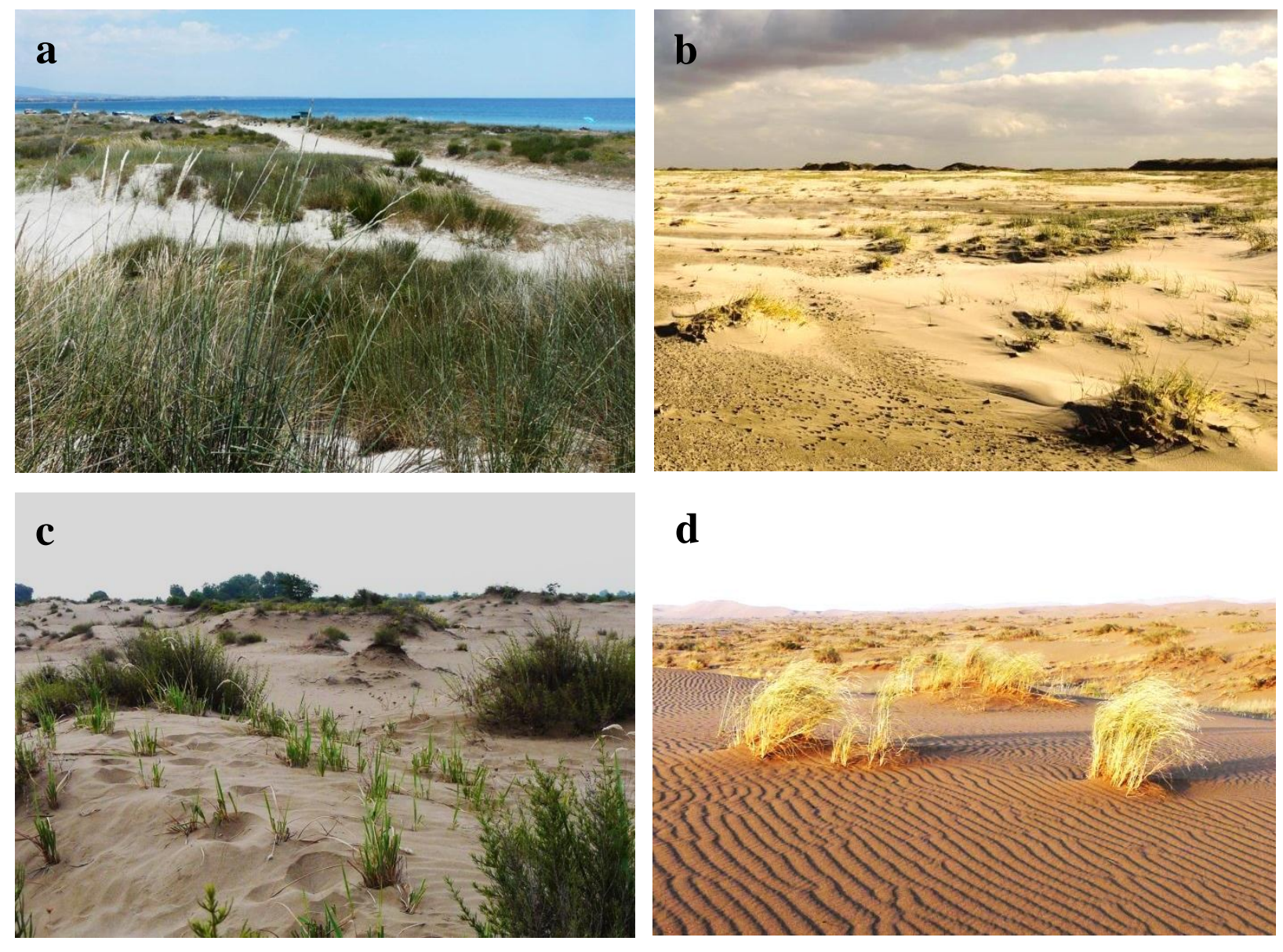

\section{d}


Fig. 3. Plant communities of mobile dunes (a-d) and salt marshes (e-f) of four biogeographic regions: a. Ammophiletea (NE Greece, Mediterranean region); b. Ammophiletea (N Germany, Atlantic); c. Artemisietea lerchianae (N Iran, Hyrcanian region); d. Stipagrostietea pennatae (C Iran, Irano-Turanian region); e. Salicornietea fruticosae (NE Greece); f. Kalidietea foliati (NE Iran). Photo 3b is created by C. Battmer. 
Chapter 3: Similarity of sand habitats across biogeographical regions |

Table 4. Synoptic table of coastal vegetation in NE Greece. Related habitats, classes and dominant functional group in each class are provided. High species constancy values in one column (or two) relative to the other columns are framed. In contrast, relatively high but unframed constancy values indicate much lower cover-abundance of the species concerned. 'Other species' with constancy of $\leq 20 \%$ are listed at the bottom of the table. Detailed information on functional groups is given in Fig. 3. Habitat: d: drift line; f: stabilized (fixed) dune; m: mobile dune; s: salt marsh; Vegetation class: A: Salicornietea fruticosae; B: Thero-Salicornietea; C: Festuco-Puccinellietea; D: Cakiletea maritimae; E: Ammophiletea; F: Helichryso-Crucianelletea maritimae.

\begin{tabular}{lllllllllllll}
\hline Community No. & $\mathbf{1}$ & $\mathbf{2}$ & $\mathbf{3}$ & $\mathbf{4}$ & $\mathbf{5}$ & $\mathbf{6}$ & $\mathbf{7}$ & $\mathbf{8}$ & $\mathbf{9}$ & $\mathbf{1 0}$ & $\mathbf{1 1}$ & $\mathbf{1 2}$ \\
\hline Number of relevés & 10 & 4 & 8 & 4 & 14 & 11 & 10 & 13 & 5 & 27 & 9 & 18 \\
\hline Habitat & s & S & s & s & s & s & s & d & m & m & f & f \\
\hline Functional group (FG) & 2 & 2 & 7 & 3 & 2 & 2 & 2 & 3 & 3 & 3 & 1 & 1 \\
\hline Vegetation class & A & A & B & C & A & A & A & D & E & E & F & F \\
\hline
\end{tabular}

Arthrocnemo glauci-Halocnemetum strobilacei

Halocnemum strobilaceum $10075 \quad \cdot \quad 21$

Arthrocnemum macrostachyum comm.

Arthrocnemum macrostachyum

Suaeda splendens

\begin{tabular}{l|lllll}
\hline 100 & & 25 & 14 &. & 10 \\
25 & 25 & $\cdot$ &. &. & 10 \\
\hline
\end{tabular}

Salicornia procumbens comm.

Salicornia procumbens

Suaeda maritima

Salsola soda

Petrosimonia brachiata

\begin{tabular}{|c|c|c|c|c|}
\hline $10 \quad 25$ & 100 & 75 & 43 & \\
\hline 20 & 88 & 75 & 50 & \\
\hline & 63 & & & 27 \\
\hline 10 & 25 & . & • & • \\
\hline
\end{tabular}

Aeluropus littoralis comm.

Aeluropus littoralis

Bupleurum tenuissimum

Polypogon maritimus

Juncus maritimus

Statico bellidifoliae-

Salicornietum fruticosae

Sarcocornia fruticosa

Limonium bellidifolium

Sarcocornio perennis-

Puccinellietum convolutae

Sarcocornia perennis

Tripolium pannonicum

Puccinellia sp.

\begin{tabular}{lll|l|lllll}
. &. & 63 & 100 & 29 & 55 & 40 &. &. \\
. & $\cdot$ & $\cdot$ & 50 & 14 & $\cdot$ & $\cdot$ &. & $\cdot$ \\
. & $\cdot$ & $\cdot$ & 50 & 14 & 9 & 40 & $\cdot$ & $\cdot$ \\
. &. & $\cdot$ & 25 & 14 & $\cdot$ & 10 & $\cdot$ & 20
\end{tabular}

\section{Halimionetum portulacoidis}

Atriplex portulacoides

Limonium narbonense

\begin{tabular}{llll|l|ll}
20 &. &. &. & 100 & 9 & 20 \\
&. &. & 50 & 29 & &.
\end{tabular}

\begin{tabular}{lllll|l|l}
10 & 50 & 38 & 50 & 36 & 100 & 70 \\
. &. & 13 &. &. & 27 & 10 \\
. & 25 & 25 & 25 & 29 & 45 & 20
\end{tabular}

\begin{tabular}{llllll|l|l}
50 & 50 & 13 & 75 & 86 & 91 & 90 \\
. &. & 13 & 25 & 29 & 55 & 70
\end{tabular}.


Puccinellia festuciformis

Plantago coronopus

Spergularia media

Juncus acutus

Elymus elongatus

\section{Salsolo-Cakiletum maritimae}

Cakile maritima

Matthiola tricuspidata

Glaucium flavum

Euphorbia peplis

Salsola tragus

Xanthium strumarium

\section{Elymetum sabulosi}

Leymus racemosus subsp. sabulosus

Chenopodium album

Sporobolus pungens

Cynodon dactylon

\begin{tabular}{lll|l|}
50 & 21 & 27 & 60 \\
25 & $\cdot$ & 18 & 30 \\
25 &. & 9 & 40 \\
25 &. & 18 & 30 \\
25 & 7 & $\cdot$ & 30
\end{tabular}

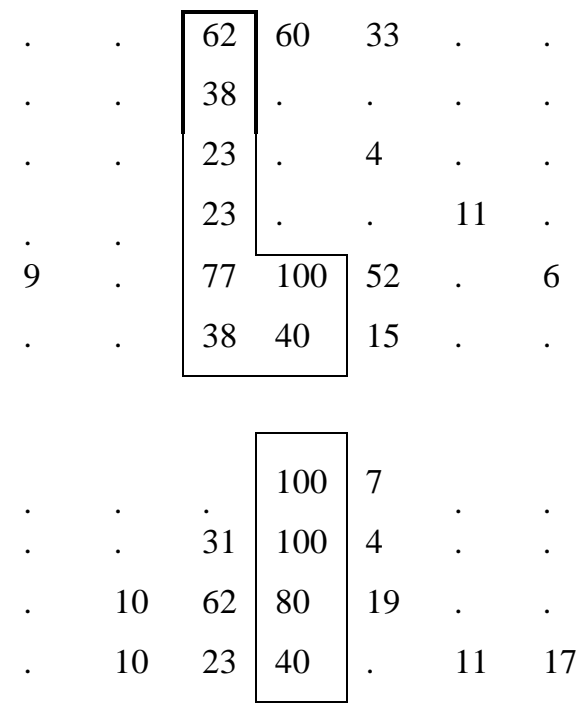

\section{Medicagini maritimae-Ammophiletum australis}

Ammophila arenaria subsp.

arundinacea

Elytrigia juncea

Vulpia fasciculata

Eryngium maritimum

Achillea maritima

Verbascum pinnatifidum

Cyperus capitatus

Medicago marina

Cynanchum acutum

Malcolmia nana

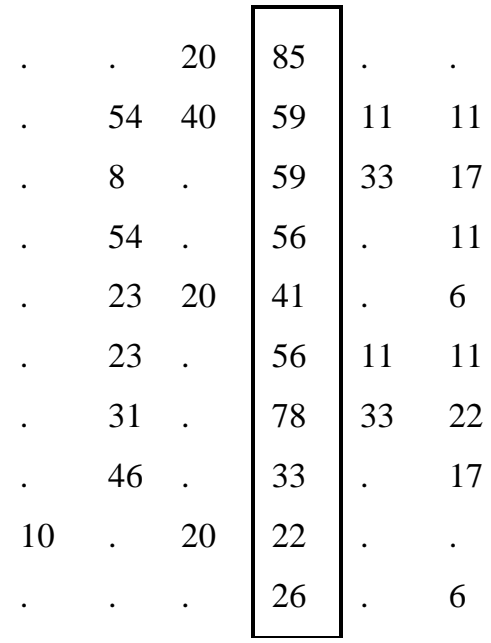

$$
\begin{aligned}
& \begin{array}{lll|l|l}
\cdot & \cdot & 26 & 67 & 28 \\
\cdot & \cdot & 26 & 67 & 17 \\
\cdot & \cdot & 4 & 33 & 22 \\
\cdot & \cdot & 4 & 22 & 6 \\
\cdot & \cdot & 4 & 33 & 28 \\
8 & 20 & 26 & 44 & 39 \\
15 & \cdot & 30 & 44 & 28 \\
8 & \cdot & 4 & 22 & .
\end{array}
\end{aligned}
$$

Artemisietum campestris

Artemisia campestris

Lomelosia argentea

Fumana procumbens

Daucus guttatus

Centaurea diffusa

Seseli tortuosum

Centaurea grisebachii

Plantago lagopus 
Chapter 3: Similarity of sand habitats across biogeographical regions |

Helianthemum salicifolium

Haplophyllum suaveolens

Silene otites

Trifolium arvense

Bromus tectorum

\begin{tabular}{ll|l|l}
$\cdot$ & $\cdot$ & 44 & \\
$\cdot$ & $\cdot$ & 44 &. \\
. & 4 & 22 & 6 \\
20 & 15 & 22 & 6 \\
\cline { 2 - 3 } & 56 & 50
\end{tabular}

\section{Ephedro distachyae-Silenetum subconicae}

Ephedra distachya

$$
15 \quad 20 \quad 15
$$

Thymbra capitata

Anthemis tomentosa

Corynephorus divaricatus

Hypericum olympicum

Sideritis montana

Erysimum calycinum

Jasione heldreichii

Silene dichotoma

Lagurus ovatus

Dasypyrum villosum

Eryngium campestre

Allium sphaerocephalon

Trifolium echinatum

Silene grisebachii

Silene conica

Phleum exaratum

Alkanna tinctoria

Astragalus sp.

$$
\begin{array}{llll|l}
\cdot & \cdot & \cdot & 11 & 56 \\
46 & \cdot & 22 & 22 & 78 \\
\cdot & \cdot & 30 & 22 & 78 \\
. & . & 26 & . & 56 \\
. & . & 4 & 56 & 72 \\
. & . & 11 & 33 & 67 \\
. & . & 26 & 11 & 56 \\
8 & . & 37 & 22 & 61 \\
8 & . & 22 & 22 & 61 \\
. & . & 22 & 11 & 28
\end{array}
$$

Other species

Hordeum marinum

$25 \quad 13$

Allium guttatum

Artemisia maritima agg.

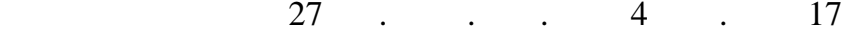

$$
\begin{aligned}
& 308
\end{aligned}
$$

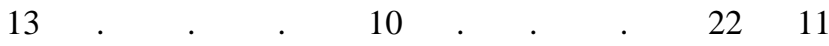

$$
\begin{aligned}
& 33 \\
& \begin{array}{lll}
7 & 22 & 17
\end{array} \\
& \begin{array}{lllll}
62 & 20 & 48 & . & 39
\end{array} \\
& 10 \cdot \cdot \cdot \cdot 33
\end{aligned}
$$$$
\text { Asperula tenella }
$$$$
\text { Avena sterilis }
$$

Bothriochloa ischaemum

Chondrilla juncea

Elytrigia bessarabica

Orobanche sp.

Papaver dubium

Trifolium tomentosum 
Chapter 3: Similarity of sand habitats across biogeographical regions |

Species with low constancy:

Aegilops geniculata 11: 11; Agrostis stolonifera 11: 11; Allium sp. 6: 9, 7: 10, 8: 8, 12: 6; Alyssum strigosum 12: 6; Alyssum umbellatum 12: 6; Anchusa sp. 11: 11; Anchusa undulata 11: 11, 12: 11; Apera intermedia 5: 7, 7: 10; Atriplex sp. 4: 50; Bassia hirsuta 10: 4; Bituminaria bituminosa 11: 11; Bromus diandrus 10: 7, 11: 11, 12: 6; Bromus intermedius 7: 20, 8: 8; Bromus japonicus 11: 22; Cachrys cristata 12: 6; Calystegia soldanella 8: 8, 10: 4; Carex divisa 7: 10; Cenchrus incertus 10: 4; Centaurea sp. 12: 11; Centaurium pulchellum 10: 4; Centaurium spicatum 4: 25, 6: 9; Chenopodium sp. 7: 10; Cichorium intybus 9: 20, 10: 4; Cirsium sp. 11: 11, 12: 6; Cistus creticus 11: 11; Corispermum nitidum 10: 7; Coronopus didymus 12: 6; Crithmum maritimum 8: 15; Cuscuta sp. 12: 6; Cyperus sp. 9: 20; Dianthus gracilis 11: 11; Dianthus monadelphus 11: 11, 12: 11; Dittrichia graveolens 10: 7, 11: 11; Dittrichia viscosa 10:15, 12: 6; Echinops sp. 11: 11; Erigeron canadensis 10: 4; Erodium cicutarium 10: 15, 11: 11, 12: 11; Euphorbia myrsinites 12: 6; Euphorbia paralias 10: 15; Filago gallica 11: 11, 12: 11; Filago vulgaris 10: 4; Fumana scoparia 11: 11; Geranium sp. 10: 4; Goniolimon incanum 11: 11, 12: 6; Goniolimon tataricum 11: 11, 12: 11; Hedypnois rhagadioloides 8: 8; Heliotropium europaeum 8: 8; Herniaria hirsuta 12: 6; Hypecoum procumbens 8: 8, 10: 4; Hypericum perforatum 11: 11; Juncus bufonius 7: 10; Juncus gerardii 6: 9, 7: 10; Juncus heldreichianus 2: 25; Juncus sp. 7: 10; Jurinea mollis 11: 11; Kochia laniflora 4: 25, 8: 8; Limonium sp. 7: 10; Linaria sp. 12: 6; Lolium rigidum 6: 9, 8: 8, 12: 6; Lotus halophilus 10: 4; Medicago disciformis 11: 11, 12: 17; Medicago littoralis 8: 8; Medicago minima 10: 4, 11: 11, 12: 6; Medicago monspeliaca 11: 11; Melica ciliata 12: 11; Melilotus indicus 11: 11; Milium vernale 12: 6; Mollugo cerviana 10: 4, 12: 6; Nigella arvensis 10: 15, 12: 11; Oenothera sp. 11: 11; Onobrychis caput-galli 11: 22; Osyris alba 11: 11, 12: 6; Pancratium maritimum 8: 8, 10: 7, 12: 11; Parapholis filiformis 3: 13, 6: 9, 7: 20; Petrorhagia illyrica 12: 6; Phragmites australis 5: 7, 7: 10, 9: 20, 11: 11; Plantago arenaria 9: 20, 10: 11, 12: 17; Plantago lanceolata 11: 22; Polycarpon tetraphyllum 10: 7; Polygonum maritimum 8: 8, 10: 7; Portulaca oleracea 11: 11; Pseudorlaya pumila 8: 8, 10: 7; Scabiosa atropurpurea 11: 11; Scabiosa webbiana 11: 11; Scirpoides holoschoenus 7: 10, 10: 4, 11: 11; Secale sylvestre 10: 4; Silene frivaldszkyana 11: 11, 12: 6; Silene gallica 8: 8, 12: 6; Silene supina 11: 22; Sonchus asper 9: 20; Sonchus oleraceus 12: 6; Sorghum halepense 11: 11; Spergularia bocconei 3: 13, 4: 25; Stipa capensis 11: 11, 12: 11; Teucrium capitatum 12: 6; Thymus sibthorpii 11: 11, 12: 17; Trifolium angustifolium 11: 11; Trifolium physodes 6: 9; Typha sp. 6: 9; Verbascum blattaria 12: 6; Vicia lutea 10: 4; Vulpia ciliata 10: 4, 11: 11, 12: 6; Xeranthemum inapertum 12: 6.

\section{Stabilized dunes}

Among the study regions, stabilized dunes have almost no syntaxon in common. Dry perennial (and annual) grasslands prevail on so-called grey dunes of the North Sea (Koelerio-Corynephoretea canescentis, Table 3, comm. 3-4), dominated by Aira praecox, Carex arenaria and Corynephorus canescens, among others. In contrast, stabilized dunes of the Mediterranean are characterized mainly by dwarf shrub vegetation of the Helichryso-Crucianelletea maritimae (Table 4, comm. 11-12). IranoTuranian vegetation of stabilized dunes is represented mainly by plant communities of two classes: the Artemisietea sieberi (Table 6, comm. 2,5,7,8), a widespread class of low-shrub vegetation covering most semi-desert areas in Iran (Zohary 1979), and the Haloxyletea ammodendri (Table 6, comm. 6,12), characterized by tall shrubs of Haloxylon ammodendron and Calligonum crinitum.

Although the regions do not share syntaxa (Table 7), vicariant communities (co-)dominated by Ephedra species are noteworthy, which form plant communities of different classes but similar in habit: Ephedro distachyae-Silenetum subconicae in NE Greece, Ephedra procera community in N Iran, and Ephedretum strobilaceae in central Iran. 
Chapter 3: Similarity of sand habitats across biogeographical regions |

Table 5 Synoptic table of coastal vegetation in N Iran. Related habitats, classes and dominant functional group in each class are provided. High species constancy values in one column (or two) relative to the other columns are framed. In contrast, relatively high but unframed constancy values indicate much lower cover-abundance of the species concerned. 'Other species' with constancy of $\leq 20 \%$ are listed at the bottom of the table. Detailed information on functional groups is given in Fig. 3. Habitat: d: drift line; f: stabilized (fixed) dune; m: mobile dune; s: salt marsh; Vegetation class: A: Juncetea maritimi; B: Thero-Salicornietea; C: Kalidietea foliati; D: Aeluropodetea littoralis; E: Saginetea maritimae; F: Cakiletea maritimae; G: Artemisietea lerchianae.

\begin{tabular}{llllllllllllll}
\hline Community No. & $\mathbf{1}$ & $\mathbf{2}$ & $\mathbf{3}$ & $\mathbf{4}$ & $\mathbf{5}$ & $\mathbf{6}$ & $\mathbf{7}$ & $\mathbf{8}$ & $\mathbf{9}$ & $\mathbf{1 0}$ & $\mathbf{1 1}$ & $\mathbf{1 2}$ & $\mathbf{1 3}$ \\
\hline Number of relevés & 10 & 18 & 5 & 12 & 6 & 3 & 7 & 5 & 5 & 2 & 6 & 3 & 8 \\
\hline Habitat & S & s & S & S & s & s & s & s & s & s & d & f & f \\
\hline Functional group (FG) & 3 & 7 & 3 & $7 / 2$ & $7 / 2$ & 3 & - & 5 & - & - & $1 / 5$ & - & 1 \\
\hline Vegetation class & A & B & A & C & C & D & C & E & E & E & F & $?$ & G \\
\hline
\end{tabular}

Juncus maritimus comm.

Juncus maritimus

Polypogon monspeliensis

\begin{tabular}{l|}
100 \\
40
\end{tabular}

Salicornia iranica comm.

Salicornia iranica

Suaeda crassifolia

$\begin{array}{llllllllll}90 & 100 & 100 & 67 & 33 & 33 & 86 & 40 & 60 & 100 \\ 60 & 33 & 40 & 33 & . & . & 29 & . & . & .\end{array}$.

Tripolium pannonicum-Salicornia iranica comm.

Tripolium pannonicum

Puccinellia distans

Phragmites australis

\begin{tabular}{ll|l|ll}
$\cdot$ & 11 & 100 & & 17 \\
$\cdot$ & 44 & 80 & 17 & 17 \\
10 & 6 & 80 & & 17
\end{tabular}

7.14

$$
\begin{array}{lll}
43 & . & 20 \\
14 & 20 & .
\end{array}
$$

Halocnemum strobilaceum comm.

Halocnemum strobilaceum

Koeleria nitidula

Frankenia pulverulenta

Centaurium erythraea

\begin{tabular}{l|l}
100 & 33 \\
50 & 50 \\
33 & 17
\end{tabular}

$33 \quad 14$

$33 \quad 33$

14

\section{Halostachys belangeriana comm.}

Halostachys belangeriana

Plantago coronopus

67

50

\begin{tabular}{l|l}
100 & 67 \\
67 &
\end{tabular}

20

Aeluropodetum littoralis

Aeluropus littoralis

Aeluropus lagopoides

\begin{tabular}{ll|l|l}
17 & & 100 & \\
58 & 50 & 67 & 14
\end{tabular}

Petrosimonia brachiata comm.

Petrosimonia brachiata

\section{Hordeum marinum comm.}

Hordeum marinum

Lolium rigidum

\begin{tabular}{llllll|l|l|l}
. & $\cdot$ & 67 & 50 & 100 & 57 & 100 & 40 \\
6 &. & 8 &. &. & $\cdot$ & 80 \\
\hline
\end{tabular}

Psylliostachys spicata comm.

Psylliostachys spicata

$6 \quad 17$

17

14

$100 \quad 50$

Frankenia hirsuta comm. 
Chapter 3: Similarity of sand habitats across biogeographical regions

\begin{tabular}{llllllllll|l|lll} 
Frankenia hirsuta &. & 17 &. & 67 & 83 & 67 & 43 & 60 & 60 & 100 \\
Sphenopus divaricatus &. &. &. & 50 & 67 & 33 &. &. & 60 &. & &. &. \\
Spergularia marina &. & 22 &. & 42 & 67 &. & 29 & 40 & 20 & 100 \\
Henrardia persica &. &. &. & 33 & 50 &. & 14 & 40 & 20 &. &. &. \\
100
\end{tabular}

\section{Cakile maritima-Arguzia sibirica comm.}

Cakile maritima

Arguzia sibirica

Salsola kali agg.

Xanthium strumarium

Ephedra procera comm.

Ephedra procera

Catapodium rigidum

Corynephorus articulatus

Crepis foetida

Petrorhagia saxifraga

Allium subnotabile

Rostraria sp.

Plantago arenaria

Bromus tectorum

Artemisia tschernieviana comm.

Artemisia tscherviniana

Cutandia memphitica

Imperata cylindrica

Daucus guttatus

Bromus diandrus

Species with low constancy:

Alhagi maurorum 6: 33; Alhagi pseudoalhagi 8: 20; Anagallis arvensis 12: 33; Atriplex sp. 5: 17; Atriplex tatarica 5: 17; Avena barbata subsp. wiestii 5: 17; Bassia hyssopifolia 3: 20, 5: 17; Brassica tournefortii 13: 25; Briza minor 1: 10; Bromus commutatus 1: 20, 9: 20; Bupleurum sp. 4: 8, 5: 17; Carex distans 1: 10; Centaurium pulchellum 9: 20; Climacoptera crassa 5: 17, 7: 14; Corispermum sp. 11: 33; Cynanchum acutum 1: 20, 8: 20; Cynodon dactylon 5: 17, 12: 33; Daucus sp. 8: 20; Elymus sp. 4: 8, 13: 13; Filago arvensis 5: 17; Chondrilla juncea 11: 17; Juncus acutus 1: 20, 11: 17; Juncus heldreichianus 1: 20; Juncus hybridus 9: 20; Juncus littoralis 1: 10; Limonium gmelinii 1: 10, 3: 33; Medicago minima 5: 17; Melilotus officinalis 5: 17, 8: 20; Mulgedium tataricum 13: 13; Parapholis incurva 9: 20; Phalaris minor 2: 11, 4: 8, 5: 17, 8: 20; Plantago ovata 4: 17; Plantago sp. 4: 8; Polygonum patulum 8: 20; Polygonum sp. 1: 10; Polypogon maritimus 4: 8; Rhamnus pallasii 12: 33; Rumex crispus 7: 14, 8: 20; Rumex dentatus 5: 17; Silene conica 12: 33; Silybum marianum 5: 17; Sonchus sp. 5: 17, 12: 33; Spergularia bocconii 2: 11, 9: 29; Spergularia diandra 2: 6; Tamarix meyeri 1: 10; Tamarix sp. 7: 14; Tetradiclis tenella 9: 40; Tragus racemosus 11: 17; Trisetaria linearis 13: 25 . 
Chapter 3: Similarity of sand habitats across biogeographical regions |

\section{Salt marshes}

This habitat shows the highest syntaxonomic similarity between regions. Pioneer annual vegetation on sea or lake shores with high salinity was identified as Thero-Salicornietea in all four regions (Table 7). Different species of Salicornia form vicarious plant communities in different phytogeographical regions. The class occurs in both coastal and inland salt marshes.

We assigned plant communities of woody halophytes in salt marshes of N Germany and NE Greece to the class Salicornietea fruticosae (Table 3, comm. 8; Table 4, comm. 1,2, 5-7), and such communities in N and central Iran to the Kalidietea foliati (Table 5, comm. 4-5; Table 6, comm. 3-4). These two classes are geographically separated. The former has been recorded in coastal areas, the latter in inland salt marshes. Although the two classes have almost no plant species in common (except Halocnemum strobilaceum), they share species with similar morphology and ecological needs (Fig. 3e, f).

The Aeluropodetea littoralis occur in alluvial temporarily flooded salt marshes in the Hyrcanian and Irano-Turanian regions. Saline habitats with fresh water influence are covered by Juncetea maritimi and Phragmito-Magnocaricetea reedbeds (Table 7). According to the European Vegetation Checklist (Mucina et al. 2016), Juncetea maritimi, Phragmito-Magnocaricetea and Saginetea maritimae are further classes common to all four or at least three regions (for the former two classes see also Akhani 2004), however without representative communities in our synoptic tables. 
Table 6. Synoptic table of sand dune vegetation in Central Iran. Related habitats, classes and dominant functional group in each class are provided. High species constancy values in one column (or two) relative to the other columns are framed. In contrast, relatively high but unframed constancy values indicate much lower cover-abundance of the species concerned. 'Other species' with constancy of $\leq 20 \%$ are listed at the bottom of the table. Detailed information on functional groups is given in Fig. 3. Habitat: d: drift line; f: fixed dune; m: mobile dune; s: salt marsh; Vegetation class: A: aff. Tamaricetea salinae; B: Artemisietea sieberi; C: Kalidietea foliati; D: Haloxyletea ammodendri; E: Stipagrostietea pennatae.

\begin{tabular}{lllllllllllll}
\hline Community No. & $\mathbf{1}$ & $\mathbf{2}$ & $\mathbf{3}$ & $\mathbf{4}$ & $\mathbf{5}$ & $\mathbf{6}$ & $\mathbf{7}$ & $\mathbf{8}$ & $\mathbf{9}$ & $\mathbf{1 0}$ & $\mathbf{1 1}$ & $\mathbf{1 2}$ \\
\hline Number of relevés & 5 & 6 & 8 & 13 & 3 & 5 & 2 & 12 & 15 & 13 & 8 & 3 \\
\hline Habitat & s & f & s & s & f & f & f & f & m & m & m & f \\
\hline Functional group (FG) & 3 & 2 & 2 & 2 & 2 & 2 & 2 & 2 & 3 & - & 3 & 2 \\
\hline Vegetation class & A & B & C & C & B & D & B & B & E & E & E & D \\
\hline
\end{tabular}

Tamarix hispida comm.

Tamarix hispida

Phragmites australis

\begin{tabular}{l|lll}
100 & 17 & 13 & 8 \\
80 &. & $\cdot$ &
\end{tabular}

Artemisietum sieberi

Artemisia sieberi

$100 . \quad 8 \quad 33 \quad \cdot \quad \cdot \quad 8$

Seidlitzietum rosmarini

Seidlitzia rosmarinus

83

100

31

8

Alhagietum pseudalhagi

Alhagi maurorum

Nitraria schoberi

Aeluropus lagopoides

Aeluropus littoralis

Cressa cretica

Ephedretum strobilaceae

Ephedra strobilacea

\begin{tabular}{lll|l|}
\cline { 3 - 3 } & 33 & 25 & 92 \\
$\cdot$ & $\cdot$ & $\cdot$ & 46 \\
20 & 17 & $\cdot$ & 46 \\
$\cdot$ & $\cdot$ & $\cdot$ & 38 \\
$\cdot$ & $\cdot$ & $\cdot$ & 23 \\
\hline
\end{tabular}

Haloxyletum ammodendri

Haloxylon ammodendron

Lomelosia olivieri

Kochia stellaris

33

100

\section{Prosopidetum farctae}

Prosopis farcta

8

$$
\begin{array}{llllll}
67 & 100 \\
67 & & & & & 8 \\
67 & 100 \\
. & 40 . & 33 & 13 & . \\
. & 33 & . & 8
\end{array}
$$

Stipagrostis plumosa comm.

Stipagrostis plumosa

Acantholepis orientalis

Gymnarrhea micrantha

Launaea acanthodes

17

Centropodia forsskalii comm.

Centropodia forsskalii

Schismus barbatus

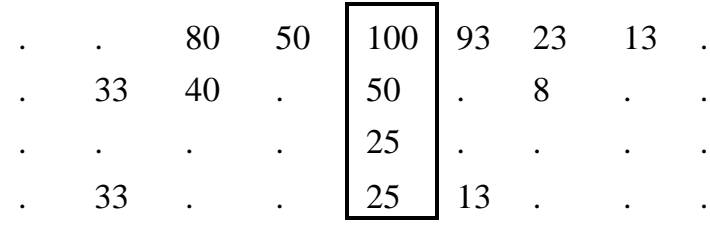

$$
\begin{array}{lllll|l|lll}
. & . & . & . & . & 73 & 8 & 50 & 33 \\
. & 33 & 80 & 100 & 58 & 73 & 31 & . & . \\
81 & & & & & & & &
\end{array}
$$


Chapter 3: Similarity of sand habitats across biogeographical regions |

Cutandia dichotoma

33

40

50

33

$93 \quad 15$

$50 \quad 33$

Cyperus eremicus comm.

Cyperus eremicus

Stipagrostis karelinii comm.

Stipagrostis karelinii

Stipagrostis barbata

Smirnovia turkestana

Heliotropium dasycarpum

Calligonum crinitum comm.

Calligonum crinitum

Other species

Aphanopleura breviseta

Astragalus squarrosus

Bromus chrysopogon

Bromus tectorum

Calligonum polygonoides

Chrozophora tinctoria

Cornulaca aucheri

Eremopyrum bonaepartis

Heliotropium arguzioides

Lappula sp.

Malcolmia africana

Peganum harmala

Salsola kali agg.

Senecio sp.

Stipagrostis pennata

Tribulus longipetalus

Tribulus terrestris

$$
\begin{array}{lllllllll}
. & 67 & 40 & . & 17 & . & . & . & . \\
. & . & 40 & . & 33 & 27 & 15 & . & . \\
. & 67 & 20 & . & 42 & 60 & 8 & 13 & . \\
. & . & . & . & . & 27 & 15 & . & . \\
. & . & 20 & . & . & 27 & 15 & . & . \\
. & . & 20 & 50 & 8 & . & . & . & . \\
. & . & 40 & . & 8 & . & . & . & . \\
8 & 33 & 40 & 50 & 42 & . & . & . & . \\
. & . & 20 & 50 & 8 & 13 & 8 & 25 & 33 \\
. & . & . & . & 8 & 27 & 15 & 25 & 67 \\
. & . & 20 & . & 25 & . & . & . & . \\
23 & . & . & 50 & . & . & . & . & . \\
. & . & 40 & 50 & 33 & . & 8 & 13 & . \\
. & 67 & 20 & . & 8 & 40 & . & . & . \\
. & . & 20 & . & 8 & 20 & 31 & 25 & . \\
. & . & . & . & 25 & . & . & . & . \\
. & . & 20 & . & 17 & . & . & . & .
\end{array}
$$

Species with low constancy:

Allium kotschyi 7: 50; Allium sp. 2: 17, 5: 33; Arabidopsis pumila 12: 33; Arnebia sp. 6: 20; Beta vulgaris s. maritima 4: 8; Camelina sp. 8: 17; Centaurea bruguierana 8: 8; Climacoptera sp. 4: 8, 9: 7; Convolvulus dorycnium 8: 8; Convolvulus chondrilloides 7: 50, 9: 7; Cynodon dactylon 4: 23, 8: 8; Echinops sp. 9: 7, 10: 8; Erodium cicutarium 6: 20, 9: 7; Fortuynia bungei 2: 17, 8: 8; Frankenia hirsuta 4: 8; Glycyrrhiza glabra 4: 8; Halimocnemis rarifolia 4: 8; Halothamnus subaphyllum 5: 33; Haplophyllum sp. 7: 50, 8: 8; Hyoscyamus species 6: 20; Isatis minima 9: 7; Juncus maritimus 1: 20, 4: 8; Koelpinia linearis 5: 33; Koelpinia sp. 9: 7; Lactuca sp. 10: 8; Launaea sp. 8: 8; Matthiola chenopodiifolia 7: 50, 10: 8; Panicum sp. 4: 8; Polygonum luzuloides 4: 15; Polypogon sp. 4: 8; Populus euphratica14: 20; Salsola praecox 12: 33; Schumannia karelinii 6: 20 , 10: 8; Sonchus sp. 4: 8; Suaeda arcuata 4: 8; Suaeda fruticosa 4: 8; Typha domingensis 1: 20; Xanthium strumarium 4: 8; Zygophyllum eichwaldii 4: 8 . 
Table 7 Syntaxonomic comparison of vegetation in the four regions (A: Atlantic; M: Mediterranean; H: Hyrcanian; IT: Irano-Turanian). Mean species richness (SR) and dominant functional group (FG) for each class as well as endangered (Red list) plant communities (only for N Germany) are provided in the table. NA: syntaxonomically not yet assigned.

\begin{tabular}{|c|c|c|c|c|c|c|c|c|c|c|}
\hline SR & FG & Class & Order & Alliance & Association & $\mathbf{A}$ & $\mathbf{M}$ & $\mathbf{H}$ & IT & $\mathbf{R}$ \\
\hline \multicolumn{11}{|c|}{ Drift line } \\
\hline \multirow[t]{4}{*}{8.5} & $4 / 5 / 3$ & Cakiletea maritimae & Atriplicetalia littoralis & $\begin{array}{l}\text { Salsolo-Minuartion } \\
\text { peploidis }\end{array}$ & Cakiletum maritimae & $*$ & & & & \\
\hline & & & & Atriplicion littoralis & Atriplicetum littoralis & $*$ & & & & \\
\hline & & & Thero-Atriplicetalia & Euphorbion peplidis & Salsolo kali-Cakiletum maritimae & & $*$ & & & + \\
\hline & & & NA & NA & $\begin{array}{l}\text { Cakile maritima-Arguzia sibirica } \\
\text { comm. }\end{array}$ & & & $*$ & & \\
\hline \multicolumn{11}{|c|}{ Mobile dune } \\
\hline \multirow[t]{3}{*}{10.1} & 3 & Ammophiletea & Ammophiletalia & Elymion arenarii & Elymo-Ammophiletum & $*$ & & & & \\
\hline & & & & Ammophilion & $\begin{array}{l}\text { Medicagini marinae- } \\
\text { Ammophiletum australis }\end{array}$ & & $*$ & & & \\
\hline & & & & Elymion gigantei & Elymetum sabulosi & & $*$ & & & \\
\hline 7.0 & $1 / 6 / 3$ & Artemisietea lerchianae & $\begin{array}{l}\text { Artemisietalia } \\
\text { tschernievianae }\end{array}$ & $\begin{array}{l}\text { Euphorbion } \\
\text { seguierianae }\end{array}$ & Artemisia tschernieviana comm. & & & * & & \\
\hline \multirow[t]{3}{*}{5.7} & 3 & Stipagrostietea pennatae & $\begin{array}{l}\text { Stipagrostietalia } \\
\text { pennatae }\end{array}$ & Stipagrostion pennatae & Stipagrostis karelinii comm. & & & & $*$ & \\
\hline & & & & & Centropodia forsskalii comm. & & & & $*$ & \\
\hline & & & & NA & Cyperus eremicus comm. & & & & $*$ & \\
\hline \multicolumn{11}{|c|}{ Stabilized dune } \\
\hline \multirow[t]{2}{*}{8.7} & 3 & Koelerio-Corynephoretea & $\begin{array}{l}\text { Corynephoretalia } \\
\text { canescentis }\end{array}$ & $\begin{array}{l}\text { Corynephorion } \\
\text { canescentis }\end{array}$ & Caricetum arenariae & $*$ & & & & + \\
\hline & & & Thero-Airetalia & Thero-Airion & Airo-Festucetum & $*$ & & & & \\
\hline \multirow[t]{2}{*}{16.8} & 1 & $\begin{array}{l}\text { Helichryso- } \\
\text { Crucianelletea maritimae }\end{array}$ & $\begin{array}{l}\text { Crucianelletalia } \\
\text { maritimae }\end{array}$ & $\begin{array}{l}\text { Crucianellion } \\
\text { maritimae }\end{array}$ & $\begin{array}{l}\text { Ephedro distachyae-Silenetum } \\
\text { subconicae }\end{array}$ & & $*$ & & & \\
\hline & & & & & Artemisietum campestris & & $*$ & & & \\
\hline 9.0 & 2 & $\mathbf{N A}$ & NA & NA & Ephedra procera comm. & & & $*$ & & \\
\hline \multirow[t]{3}{*}{6.4} & 2 & Artemisietea sieberi & Artemisietalia sieberi & Artemision sieberi & Artemisietum sieberi & & & & $*$ & \\
\hline & & & & NA & Stipagrostis plumosa comm. & & & & $*$ & \\
\hline & & & & Prosopidion farctae & Prosopidetum farctae & & & & $*$ & \\
\hline
\end{tabular}


Chapter 3: Similarity of sand habitats across biogeographical regions |

\begin{tabular}{|c|c|c|c|c|c|c|c|c|c|c|}
\hline SR & FG & Class & Order & Alliance & Association & $\mathbf{A}$ & $\mathbf{M}$ & $\mathbf{H}$ & IT & $\mathbf{R}$ \\
\hline \multirow{3}{*}{3.9} & \multirow{3}{*}{2} & \multirow{3}{*}{ Haloxyletea ammodendri } & \multirow{3}{*}{$\begin{array}{l}\text { Haloxyletalia } \\
\text { ammodendri }\end{array}$} & Ephedrion strobilaceae & Ephedretum strobilaceae & & & & $*$ & \\
\hline & & & & Haloxylion & Haloxyletum ammodendri & & & & $*$ & \\
\hline & & & & ammodendri & Calligonum crinitum comm. & & & & $*$ & \\
\hline \multicolumn{11}{|c|}{ Salt marsh } \\
\hline \multirow[t]{6}{*}{4.0} & \multirow[t]{6}{*}{7} & \multirow[t]{6}{*}{ Thero-Salicornietea } & \multirow[t]{6}{*}{ Thero-Salicornietalia } & \multirow{3}{*}{$\begin{array}{l}\text { Salicornion } \\
\text { dolichostachyo-fragilis } \\
\text { Salicornion } \\
\text { ramosissimae }\end{array}$} & Salicornietum strictae & $*$ & & & & \\
\hline & & & & & Salicornietum ramosissimae & $*$ & & & & + \\
\hline & & & & & Suaedetum maritimae & $*$ & & & & + \\
\hline & & & & Thero-Salicornion & Salicornia procumbens comm. & & $*$ & & & \\
\hline & & & & NA & Salicornia iranica comm. & & & $*$ & & \\
\hline & & & & NA & Salicornia persica comm. ${ }^{1}$ & & & & & \\
\hline \multirow[t]{3}{*}{6.2} & \multirow[t]{3}{*}{5} & \multirow[t]{3}{*}{ Saginetea maritimae } & $\begin{array}{l}\text { Frankenietalia } \\
\text { pulverulentae }\end{array}$ & $\begin{array}{l}\text { Frankenion } \\
\text { pulverulentae }\end{array}$ & Hordeum marinum comm. ${ }^{2}$ & & & $*$ & & \\
\hline & & & NA & NA & Psylliostachys spicata comm. & & & $*$ & & \\
\hline & & & NA & NA & Frankenia hirsuta comm. & & & $*$ & & \\
\hline \multirow[t]{3}{*}{5.8} & \multirow[t]{3}{*}{2} & \multirow[t]{3}{*}{ Salicornietea fruticosae } & \multirow[t]{3}{*}{$\begin{array}{l}\text { Salicornietalia } \\
\text { fruticosae }\end{array}$} & \multirow[t]{2}{*}{ Salicornion fruticosae } & Halimionetum portulacoidis & $*$ & $*$ & & & + \\
\hline & & & & & $\begin{array}{l}\text { Statico bellidifoliae-Salicornietum } \\
\text { fruticosae } \\
\text { Sarcocornio perennis- } \\
\text { Puccinellietum convolutae }\end{array}$ & & * & & & \\
\hline & & & & Arthrocnemion glauci & $\begin{array}{l}\text { Arthrocnemum macrost. comm. } \\
\text { Arthrocnemo glauci- } \\
\text { Halocnemetum strobilacei }\end{array}$ & & * & & & \\
\hline \multirow[t]{5}{*}{5.9} & \multirow[t]{5}{*}{$2 / 7$} & \multirow[t]{5}{*}{ Kalidietea foliati } & Kalidietalia foliati & Kalidion caspici & $\begin{array}{l}\text { Halocnemum strobilaceum } \\
\text { comm. }\end{array}$ & & & $*$ & & \\
\hline & & & & & Halostachys belangeriana comm. & & & $*$ & & \\
\hline & & & & & Alhagietum pseudalhagi & & & & $*$ & \\
\hline & & & & Seidlitzion rosmarini & Seidlitzietum rosmarini & & & & $*$ & \\
\hline & & & NA & NA & Petrosimonia brachiata comm. & & & $*$ & & \\
\hline 2.3 & 3 & $\begin{array}{l}\text { Phragmito- } \\
\text { Magnocaricetea }\end{array}$ & Scirpetalia maritimi & Scirpion maritimi & Scirpetum maritimi & $*$ & & & & \\
\hline
\end{tabular}


Chapter 3: Similarity of sand habitats across biogeographical regions

\begin{tabular}{|c|c|c|c|c|c|c|c|c|c|}
\hline $\mathbf{S R}$ & FG & Class & Order & Alliance & Association & $\mathbf{A}$ & $\mathbf{M}$ & H IT & $\mathbf{R}$ \\
\hline \multicolumn{10}{|c|}{ Salt marsh } \\
\hline \multirow[t]{4}{*}{5.6} & 3 & Juncetea maritimi & $\begin{array}{l}\text { Puccinellio } \\
\text { maritimae- } \\
\text { Salicornietalia }\end{array}$ & Armerion maritimae & Juncetum gerardii & $*$ & & & \\
\hline & & & & Festucion maritimae & Limonietum vulgaris & $*$ & & & \\
\hline & & & Juncetalia maritimae & Juncion maritimae & Juncus maritimus comm. & & & $*$ & \\
\hline & & & & NA & $\begin{array}{l}\text { Tripolium pannonicum-Salicornia } \\
\text { iranica comm. }\end{array}$ & & & $*$ & \\
\hline 10.2 & 3 & Festuco-Puccinellietea & Puccinellietalia & $\begin{array}{l}\text { Puccinellion } \\
\text { convolutae }\end{array}$ & Aeluropus littoralis comm. & & * & & \\
\hline 6.3 & 3 & Aeluropodetea littoralis & $\begin{array}{l}\text { Aeluropodetalia } \\
\text { littoralis }\end{array}$ & Aeluropodion littoralis & Aeluropodetum littoralis ${ }^{4}$ & & & $*$ & \\
\hline
\end{tabular}

Communities with superscript 1-4 did not occur in the synoptic table 6 (C Iran) but in literature for central Iran: 1 Akhani (2003); 2 Alaie (2001); 3 Akhani (2004); 4 Asri \& Ghorbanli (1997). 
Chapter 3: Similarity of sand habitats across biogeographical regions |

\section{Functional diversity and similarity}

Although the four regions turned out to be quite different in terms of plant species pools and vegetation types (especially of mobile and stabilized dunes), the species of similar habitats may be functionally analogous. Common habitat features indeed resulted in similar functional groups of species. The proportion of different functional groups in classes and per region is shown in Fig. 4 and the prevailing functional group per class is given in Table 7. The significance of the differences between functional groups of each community was approved by the results of the Kruskal-Wallis test $(P<0.01)$.

Ammophiletea, Artemisietea lerchianae and Stipagrostietea pennatae are geographically distinct but very similar in having the highest proportion of graminoid perennials (FG3) (Fig. 3a-d, Fig. 4, Table 7), chiefly rhizomatous clonal grasses, wind pollinated and dispersed, and CS/CSR strategy. Such plants can cope with the extreme habitat conditions of mobile dunes, such as wind erosion, sand burial and water deficiency. Plant communities of the Artemisietea lerchianae include non-graminoid perennials (FG1) and shrubs (FG2) in addition to the graminoid perennials (FG3) with more or less the same proportion.

Plant communities on stabilized dunes are adapted to dry conditions with chiefly three groups of species: nongraminoid perennials (FG1), shrubs (FG2), and graminoid perennials (FG3), such as of the Stipagrostis plumosa community. Stabilized dunes of central Iran are dominated by shrubs (FG2) with reduced leaves, long roots and thickened stems/roots, mostly pollinated and dispersed by wind. The plant communities belong either to the class Artemisietea sieberi, characterized by small shrubs of up to $1 \mathrm{~m}$, or to the Haloxyletea ammodendri, with shrubs up to $3 \mathrm{~m}$ tall. In Hyrcanian $\mathrm{N}$ Iran shrubs and graminoid perennials form communities on stabilized dunes, while in NE Greece graminoid (FG3) and non-graminoid perennials (FG1) prevail in this habitat type. Helichryso-Crucianelletea maritimae are dominated by cushions or prostrate plants with frequently dense indumentum, with long tap root and/or woody stem, mostly dispersed by wind but pollinated by insects. Graminoid perennials are dominant in stabilized dunes of N Germany. In the Cakiletea maritimae, the ruderal strategists (FG4) and insect-pollinated annuals are prominent functional groups (Fig. 2). 

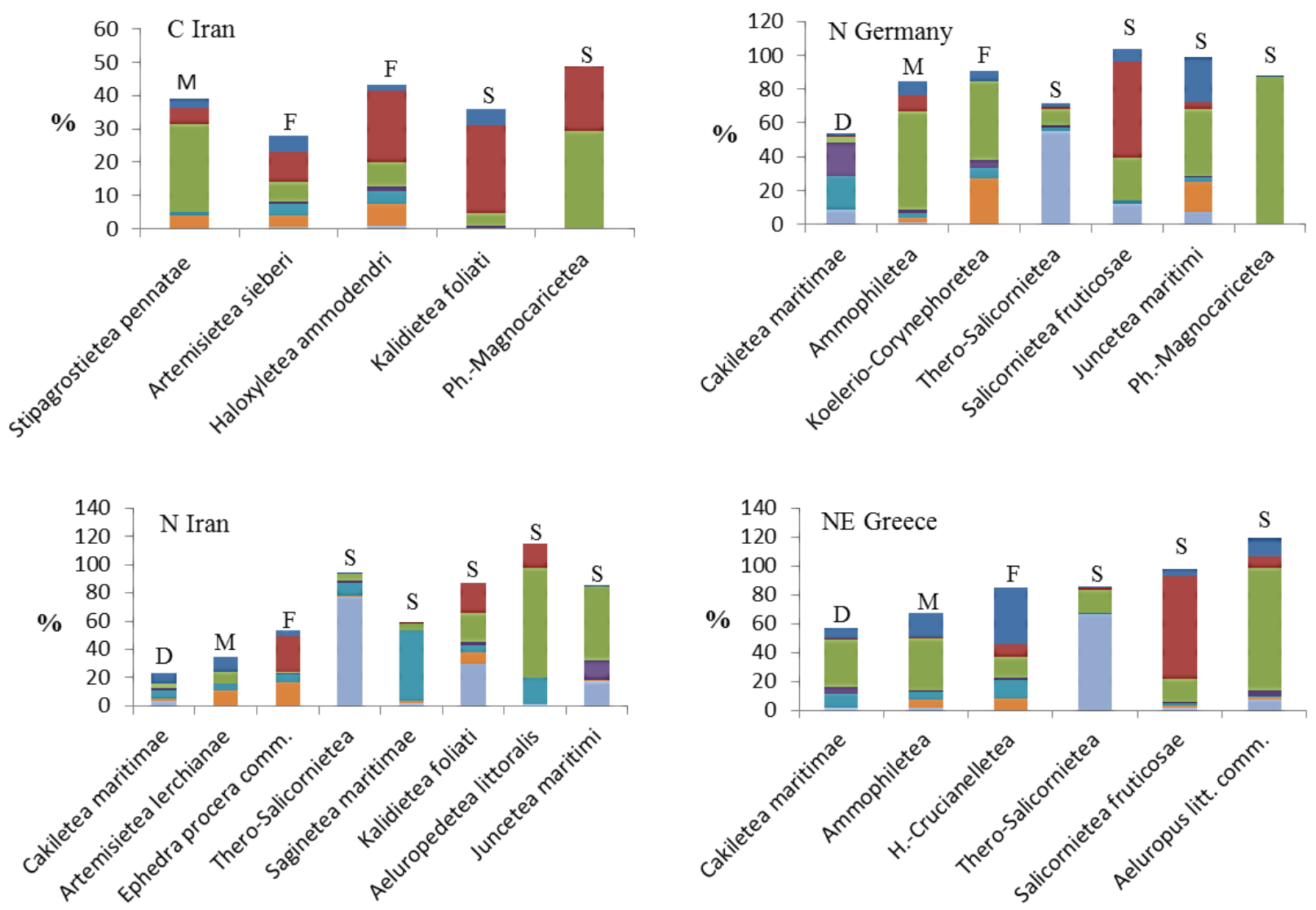

\section{FG1 Non-graminoid perennials \\ FG2 Shrubs \\ FG3 Graminoid perennials \\ FG4 Annual ruderals \\ FG5 Insect-pollinated annuals \\ FG6 Annual grasses \\ FG7 Annual succulents}

Fig. 4 Cumulative cover proportions (in \%) of functional groups in the vegetation classes of each region. Habitat types above the columns: D: drift line; M: mobile dune; F: stabilized (fixed) dune; S: salt marshes. Total cover exeeds $100 \%$ in some cases because of vegetation layer overlap. The differences between functional groups of each community were significant (Kruskal-Wallis test, $\mathrm{P}<0.01$ ).

Plant communities on the salt marshes consist mostly of three functional groups. Annual succulents (FG7) occur in four regions and refer to the Thero-Salicornietea. Woody halophytes (FG2) with reduced leaves and/or succulent stems, adapted to high salinity, are most prominent in both coastal (Salicornietea fruticosae) and inland (Kalidietea foliati) salt marshes. Graminoid perennials (FG3) include rhizomatous or tussock-forming sedges and rushes of the Juncetea maritimi and Phragmito-Magnocaricetea (Table 7). 
Chapter 3: Similarity of sand habitats across biogeographical regions |

\section{Discussion}

\section{Taxonomic and syntaxonomic similarities}

Our findings show that the plant species composition of coastal and inland sand ecosystems is more related to the biogeographic (climatic) region than to habitat features. At both species and genus level, there is very low similarity in habitats of the same kind across regions as well as across such habitats within a region (Fig. 2, Table 1-2). As far as species and community composition are concerned, biogeographical distance, whether through climate or chorological and evolutionary history, prevails over environmental similarity. However, this effect varied among the four halophytic habitats. Mobile and stabilized dunes showed more region-related patterns at both taxonomic and syntaxonomic levels and their species composition thus reflected to some extent the biogeographic position of the area. Our results are in accordance with findings in the coastal vegetation of the Iberian Peninsula (Jiménez-Alfaro et al. 2015), where dune habitats were found to be controlled by climatic (temperature and precipitation) patterns, an effect that was more significant in stable dunes. In conclusion, the level of azonality of the vegetation of mobile and stabilized dunes, as appears from the amount of supraregional taxonomic and syntaxonomic dissimilarities and individuality, is lower than in the other sand ecosystems under study.

At syntaxonomic level, salt marshes and drift lines show considerable similarities between regions, whereas mobile and stabilized dunes have very little in common. Sand ecosystems in general are known as stress-prone habitats but among the four studied habitat types, salt marshes and drift lines are exposed to at least temporarily particularly high salinity (Pennings \& Bertness 2001) and, as far as strandline vegetation is concerned, disturbance (Grime 2006). Extreme habitat conditions play an important role in forming plant associations (Mucina et al. 2006). The narrow ecological niche available in highly stressful habitats acts as an environmental filter, which selects the few tolerant species with morphological and physiological character traits that suit such habitats (Gallego-Fernández \& Martínez 2011; Bermúdez \& Retuerto 2013). Therefore, the more stress-prone a habitat, the more is its vegetation habitat-related and independent from the biogeographic region, virtually locked against the regional species pool. This explains why the highest numbers of species, genera and syntaxa in common at different biogeographical regions were recorded in salt marshes and drift lines, and it explains the low species richness of these habitats in comparison to others, e.g. 4-6 species per plot in salt marshes (similarly low numbers reported by, e.g., Isermann 2005 and Acosta et al. 2009). Therefore, from a taxonomic and syntaxonomic point of view, salt marsh and drift line vegetation show a particularly high degree of 'azonality'.

\section{Functional similarity}

Extreme environmental conditions have considerable effects on the morphology of plants and the functional composition of plant communities (de Bello et al. 2013), i.e. the proportion of functional groups. We observed 
Chapter 3: Similarity of sand habitats across biogeographical regions |

that the prevailing vegetation of each habitat type has similar functional composition across different regions, while different sand habitats of one region have fewer functional groups in common. At the level of functional traits, the vegetation is more independent of the regional climate and biogeography, and highest trait similarities occurred among habitats of the same kind but of different regions. The filtering effect of habitat on plant functional composition was shown by Tecco et al. (2010), where no significant differences between functional attributes of herbaceous alien and native species of the same habitat under different climatic conditions were found. Regarding the functional aspect of vegetation and in contrast to the taxonomic and syntaxonomic perspective (see above), all studied ecosystems, including mobile and stabilized dunes, form azonal vegetation. They share functional groups of species independent from the climatic region.

In some cases, we noticed that a certain functional group (co-)dominated in vegetation types of different habitats. Graminoid perennials (FG3) for instance predominate in various habitats. Sedge and rush communities of wet salt marshes (Juncetea maritimi) as well as grass communities on mobile dunes (Ammophiletea), both FG3, are using similar strategies to overcome environmental stress. Equipped with storage organs (carbohydrate stored in rhizomes or at the base of the tussocks), plants can establish in stress-prone habitats and withstand periodical drought, while clonality enables them to occupy suitable places, withstand disturbance and to compete with other plants (CS or CSR strategy) in using the limited habitat resources (Maun 2009). Wind dispersal facilitates the establishment of new colonies. With help of these strategies, plants can overcome the harsh conditions of various habitat types, whether it is sand burial and erosion in mobile dunes or inundation and desiccation in salt marshes.

Similarly, in stabilized dunes as well as in salt marshes, FG2 plants (includes tall or low shrubs) figure prominently. By reduced leaves, photosynthetically active stems and/or succulent leaves, FG2 shrubs are well adapted to dry or saline habitat conditions. The high salinity of salt marshes as well as the dry conditions of stabilized dunes affects the availability of water, to which plants respond to by similar drought adaptation traits. Additional functional traits (and hence more sophisticated functional groups) may result in finer differentiation of functional vegetation characteristics in different habitats.

We believe that functional groups are useful to understand and describe plant communities as reflecting habitat and ecosystem conditions. Functional aspects of the vegetation can be applied in addition to species composition (and presence of diagnostic species) for defining high-rank syntaxa and also for comparing plant communities across different regions ('coeno-syntaxa', e.g. Deil 1989). While phytosociologists have used multiple morphological characters of vegetation to describe the 'texture' of plant communities since long ('synmorphology', e.g. Barkman 1979; Dierschke 1994), applying functional groups provides a wider range of character traits and a more consistent approach. For example, the woody salt marsh communities of the Kalidietea foliati and Salicornietea fruticosae are dominated by species of similar function (FG2). Plant communities of both classes have very similar ecological needs, plant morphology and trait characteristics as a response to similar environmental stress. The two classes represent the same kind of habitat and are to be 
Chapter 3: Similarity of sand habitats across biogeographical regions |

considered as ecological counterparts and geographically vicariant syntaxa, which might even be combined into a single class, quite like some researchers include inland salt marsh shrub communities of the Iberian peninsula in the Salicornietea fruticosae (Fuente et al. 2013, Rufo et al. 2016).

\section{A note on Halocnemum dominated vegetation}

Plant assemblages dominated by Halocnemum strobilaceum (Halocnemetum strobilacei) are occurring in both inland and coastal areas of Iran as well as in European coastal salt marshes. The syntaxonomic position of the Halocnemetum strobilacei remains unclear, as it is grouped under different high-rank syntaxa in different regions. According to European authors (e.g., Rivas-Martínez et al. 2001), the Halocnemetum strobilacei belongs to the alliance Arthrocnemion glauci of the class Salicornietea fruticosae. In inland salt marshes of central Iran, the association of Halocnemum strobilaceum was first reported by Zohary (1973) under its own class 'Halocnemetea irano-anatolicae'. This illegitimate name was changed into Halocnemetea strobilacei (yet without sufficient diagnosis) by Asri \& Ghorbanli (1997) and then reduced to synonymy under Salicornietea fruticosae by Akhani (2004). Some authors (e.g. Schaminée et al. 2012; Mucina et al. 2016), assigned salt marsh communities dominated by Halocnemum strobilaceum with similar, if not identical, species composition into two alliances, the Caspian Kalidion caspici and the Mediterranean Arthrocnemion glauci, respectively. One solution is to consider all Halocnemum-dominated salt marsh communities with similar ecology as one association Halocnemetum strobilacei in the class Salicornietea fruticosae irrespective of its region or its location (Biondi et al. 2014). However, if Halocnemum strobilaceum turns out to be an aggregate of as yet undetected vicarious species (or subspecies) in different regions (see Biondi et al. 2013), similar to the Salicornia europaea aggregate (Kadereit et al. 2006), the syntaxonomic similarity of the respective communities would decrease as well. Pending molecular and in-depth morphological studies, the taxonomy of Halocnemum and the syntaxonomy of the 'Halocnemetum strobilacei' remain open questions.

\section{Conservation value}

Coastal sand habitats rank among the most endangered and threatened ecosystems worldwide (EEA 2008). Urbanization, agriculture and touristic development are the most important factors leading to habitat degradation, fragmentation, and species and habitat loss (Buffa et al. 2012; Pintó et al. 2014). From the 11 associations of coastal sand habitats recorded by us in N Germany, five communities are listed as 'Endangered' (Rennwald 2000): three of salt marshes, one of drift lines and one of stabilized dunes. Yet in many national Red Lists these habitats and their plant species are not well represented (van der Maarel \& van der Maarel-Versluys 1996). Based on our field observations, habitat loss and fragmentation is a serious problem particularly in coastal areas of N Iran and NE Greece, but also in Germany. The coastal vegetation in N Iran is already destroyed in many parts and in NE Greece under high pressure. Also the Cakiletum maritimae as well as several plant communities of stabilized dunes are highly vulnerable or threatened almost everywhere. Therefore, we 
Chapter 3: Similarity of sand habitats across biogeographical regions |

emphasize the necessity of effective protection strategies for preserving the remaining sand dunes and salt marshes and restoring damaged habitats within and beyond our study areas.

\section{Author contribution}

P.M. conducted the research, performed analyses and wrote the manuscript, E.B. contributed in planning the research, revised and improved the manuscript, M.I. critically revised the manuscript and provided a regional dataset.

\section{Acknowledgements}

We would like to thank the Reinhold-und-Johanna-Tüxen-Stiftung for funding the field work in Iran for P.M. 'Management Body of Delta Nestos, Lakes Vistonida-Ismarida' in Greece and departments of 'Natural Resources of Esfahan' and 'Nature Conservation of Mazandaran' in Iran are gratefully acknowledged for their

help for visiting the areas. The Editor's and reviewer's comments and corrections helped to improve the manuscript and are gratefully acknowledged. 
Chapter 3: Similarity of sand habitats across biogeographical regions |

\section{References}

Acosta, A., Ercole, S., Stanisci, A., \& Blasi, C. 2006. Sandy coastal ecosystems and effects of disturbance in central Italy. Journal of Coastal Research SI 39: 985-989.

Acosta, A., Ercole, S., Stanisci, A., Pillar, V.D., \& Blasi, C. 2007. Coastal vegetation zonation and dune morphology in some Mediterranean ecosystems. Journal of Coastal Research 23 (6): 1518-1524.

Acosta, A., Carranza, M.L., \& Izzi, C.F. 2009. Are there habitats that contribute best to plant species diversity in coastal dunes? Biodiversity and Conservation 18: 1087-1098.

Akhani, H. 2003. Salicornia persica AKHANI (Chenopodiaceae), a remarkable new species from Central Iran. Linzer biol. Beitr. 35: 607-6012.

Akhani, H. 2004. Halophytic vegetation of Iran: towards a syntaxonomical classification. Annali di Botanica 4: $65-82$.

Alaie, E. 2001. Salt marshes and salt deserts of S.W. Iran. Pakistan Journal of Botany 33: 77-91.

Asri, Y. 2003. Plant diversity in Kavir Biosphere Reserve, Iran. Research Institute of Forests and Rangelands, Tehran. [In Persian.]

Asri, Y., \& Ghorbanli, M. 1997. The halophilous vegetation of the Orumieh lake salt marshes, NW. Iran. Plant Ecology 132: 155-170.

Barkman, J.J. 1979. The investigation of vegetation texture and structure. In: Werger, M.J.A. (ed) The study of vegetation, pp. 123-160. Junk, The Hague, NL.

Bello, F. de, Lavorel, S., Lavergne, S., Albert, C.H., Boulangeat, I., Mazel, F., \& Thuiller, W. 2013. Hierarchical effects of environmental filters on the functional structure of plant communities: a case study in the French Alps. Ecography 36: 393-402.

Bermúdez, R., \& Retuerto, R. 2013. Living the difference: Alternative functional designs in five perennial herbs coexisting in a coastal dune environment. Functional Plant Biology 40: 1187-1198.

Biondi, E., Casavecchia, S., Estrelles, E., \& Soriano, P. 2013. Halocnemum M. Bieb. vegetation in the Mediterranean Basin. Plant Biosystems 147: 536-547.

Biondi, E., Blasi, C., Allegrezza, M., Anzellotti, I., Azzella, M.M., Carli, E., Casavecchia, S., Copiz, R., Del Vico, E., (...) \& Zivkovic, L. 2014. Plant communities of Italy: The Vegetation Prodrome. Plant Biosystems 148: 728-814.

Buffa, G., Fantinato, E., \& Pizzo, L. 2012. Effects of disturbance on sandy coastal ecosystems of N-Adriatic Coasts ( Italy ). In: Lameed, G.A. (ed) Biodiversity enrichment in a diverse world, pp. 339-372. InTech, Croatia. 
Chapter 3: Similarity of sand habitats across biogeographical regions |

Buttler, K.P., Thieme, M., \& Mitarbeiter. 2015. Florenliste von Deutschland - Gefäßpflanzen, Version 7. Frankfurt am Main, DE. URL: http://www.kp-buttler.de/

Carranza, M.L., Acosta, A.T.R., Stanisci, A., Pirone, G., \& Ciaschetti, G. 2008. Ecosystem classification for EU habitat distribution assessment in sandy coastal environments: An application in central Italy. Environmental Monitoring and Assessment 140: 99-107.

Defeo, O., McLachlan, A., Schoeman, D.S., Schlacher, T. A., Dugan, J., Jones, A., Lastra, M., \& Scapini, F. 2009. Threats to sandy beach ecosystems: A review. Estuarine, Coastal and Shelf Science 81: 1-12.

Deil, U. 1989. Adiantetea-Gesellschaften auf der Arabischen Halbinsel, Coenosyntaxa in dieser Klasse sowie allgemeine Überlegungen zur Phylogenie von Pflanzengesellschaften. Flora 182: 247-264.

Dierschke, H. 1994. Pflanzensoziologie - Grundlagen und Methoden. Ulmer, Stuttgart, DE.

Dimopoulos, P., Raus, T., Bergmeier, E., Constantinidis, T., Iatrou, G., Kokkini, S., Strid, A., \& Tzanoudakis, D. 2013. Vascular plants of Greece: An annotated checklist. [Englera 31] Botanic Garden and Botanical Museum Berlin-Dahlem, Berlin, DE, and Hellenic Botanical Society, Athens, GR.

Doing, H. 1985. Coastal fore-dune zonation and succession in various parts of the world. Vegetatio 61: 65-75.

EEA, European Environment Agency. 2008. Article 17 Technical Report 2001-2006, Brussels. Ellenberg, H., \& Leuschner, C. 2010. Vegetation Mitteleuropas mit den Alpen in ökologischer, dynamischer und historischer Sicht. $6^{\text {th }}$ ed. Ulmer, Stuttgart, DE.

European Commission. 2013. Natura 2000. Interpretation Manual of European Union Habitats. EUR28. DG Environment, Brussels, BE.

Fuente, V. de la, Rufo, L., Teijeiro, A., \& Sanchez-Mata, D. 2013. Arthrocnemo macrostachyi-Sarcocornietum hispanicae, a new halophytic plant community from eastern Iberian Península. Lazaroa 34: 267-272.

Gallego-Fernández, J.B., \& Martínez, M.L. 2011. Environmental filtering and plant functional types on Mexican foredunes along the Gulf of Mexico. Ecoscience 18: 52-62.

Grime, J.P. 2006. Plant strategies, vegetation processes, and ecosystem properties. $2^{\text {nd }}$ ed. John Wiley \& Sons, Chichester, EN.

Hill, M.O. 1979. TWINSPAN - A FORTRAN program for arranging multivariate data in an ordered two- way table by classification of the individuals and attributes. Cornell University, New York, US.

Hollander, M. \& Wolfe, D.A. 1973. Nonparametric Statistical Methods. John Wiley \& Sons, New York, US.

Isermann, M. 2005. Soil pH and species diversity in coastal dunes. Plant Ecology 178:111-120.

Jiménez-Alfaro, B., Marcenò, C., Guarino, R., \& Chytrý, M. 2015. Regional metacommunities in two coastal 
Chapter 3: Similarity of sand habitats across biogeographical regions |

systems: spatial structure and drivers of plant assemblages. Journal of Biogeography 42: 452-462.

Kadereit, G., Mucina, L. \& Freitag, H. 2006. Phylogeny of Salicornioideae (Chenopodiaceae): diversification, biogeography, and evolutionary trends in leaf and flower morphology. Taxon 55: 617-642.

Lavrentiades, G.J. 1975. On the vegetation of the Porto-Lagos coasts. In: Jordanov, D. \& al. (eds.) Problems of Balkan Flora and Vegetation, pp. 365-379. Publishing House of the Bulgarian Academy of Sciences, Sofia, BU.

Léonard, J. 1992. Contribution a l'etude de la flore et de la vegetation des deserts d'Iran, fasc. 10. Jardin botanique national de Belgique, Meise, BE.

Lienau, C. 1989. Griechenland. [Wissenschaftliche Länderkunden 32] Wissenschaftliche Buchgesellschaft, Darmstadt, DE.

Mahdavi, P. \& Bergmeier, E. 2016. Plant functional traits and diversity in sand dune ecosystems across different biogeographic regions. Acta Oecologica 74: 37-45.

Maun, A. 1998. Adaptations of plants to burial in coastal sand dunes. Canadian Journal of Botany 76: 713-738.

Maun, A. 2009. The biology of coastal sand dunes. Oxford University Press, Oxford, EN.

Mucina, L., \& O'Callaghan, M. 2003. Syntaxonomy and zonation patterns in coastal salt marshes of the Uilkraals esturay, Western Cape (South Africa). Phytocoenologia 33: 309-334.

Mucina, L., Rutherford, M.C., \& Powrie, L.W. 2006. Inland azonal vegetation, The vegetation of South Africa, Lesotho and Swaziland. Strelitzia 19: 617-657.

Mucina, L., Bültmann, H., Dierßen, K., Theurillat, J.-P., Raus, T., , Čarni, A., Šumberová, K., Willner, W., Dengler, J., (...) \& Tichý, L. 2016. Vegetation of Europe: hierarchical floristic classification system of vascular plant, bryophyte, lichen, and algal communities. Applied Vegetation Science 19: 3-264.

Oksanen, J., Kindt, R., Legendre, P., O’Hara, B., Simpson, G.L., Solymos, P., Stevens, M.H.H. \& Wagner, H. 2008. Vegan: community ecology package. $\mathrm{R}$ package version 1.15-1. URL: http://cran.rproject.org/package=vegan

Pennings, S.C., \& Bertness, M.D. 2001. Salt marsh communities. In: Bertness, M.D., Gaines, S.D., \& Hay, M. (eds.) Marine Community Ecology, pp. 289-316. Sinauer Associates, Sunderland, Massachusetts, US.

Pennings, S.C., \& Callaway, R.M. 1992. Salt marsh plant zonation: The relative importance of competition and physical factors. Ecology 73: 681-690.

Pintó, J., Martí, C., \& Fraguell, R.M. 2014. Assessing current conditions of coastal dune systems of Mediterranean developed shores. Journal of Coastal Research 296: 832-842.

Pott, R. 1995. Die Pflanzengesellschaften Deutschlands. $2^{\text {nd }}$ ed. Ulmer. Stuttgart, DE. 
Chapter 3: Similarity of sand habitats across biogeographical regions |

Provoost, S., Ampe, C., Bonte, D., Cosyns, E. \& Hoffmann, M. 2004. Ecology, management and monitoring of grey dunes in Flanders. Journal of Coastal Conservation 10: 33.

Rechinger, K.H. (ed) 1963-2012. Flora Iranica 1-178. Akademische Druck und Verlagsanstalt, Graz, Naturhistorisches Museum, Wien, AU.

Rennwald, E. (comp.) 2000. Verzeichnis und Rote Liste der Pflanzengesellschaften Deutschlands. Mit Datenservice auf CD-ROM. [Schriftenreihe für Vegetationskunde 35] Bundesamt für Naturschutz, Bonn - Bad Godesberg, DE.

Rivas-Martínez, S., Fernández-González, F., Loidi, J., Lousã, M. \& Penas, A. 2001. Syntaxonomical checklist of vascular plant communities of Spain and Portugal to association level. Itinera Geobotanica 14: 5-341.

Rodwell, J.S., Schaminée, J.H.J., Mucina, L.P., Pignatti, S., Dring, J., \& Moss, D. 2002. The diversity of European vegetation. An overview of phytosociological alliances and their relationships to EUNIS habitats. National Reference Centre for Agriculture, Nature and Fisheries, [report no. EC-LNV 2002(054)], Wageningen, NL.

Rufo, L., de la Fuente, V. \& Sánchez-Mata, D. 2016. Sarcocornia plant communities of the Iberian Peninsula and the Balearic Islands. Phytocoenologia 46: 385-396.

Schaminée, J.H.J., Chytrý, M., Hennekens, S.M., Mucina, L., Rodwell, J.S., \& Tichý, L. 2012. Development of vegetation syntaxa crosswalks to EUNIS habitat classification and related data sets. Alterra, [Final report EEA/NSV/12/001], Wageningen, NL.

Sciandrello, S., \& Tomaselli, V. 2013. Coastal salt-marshes plant communities of the Salicornietea fruticosae class in Apulia (Italy). Biologia 69: 53-69.

Sykora, Babalonas, D., \& Papastergiadou, E.S. 2003. Strandline and sand-dune vegetation of coasts of Greece and some other Aegean countries. Phytocoenologia 33: 409-446.

Tecco, P., Diaz, S., Cabido, M., \& Urcelay, C. 2010. Functional traits of alien plants across contrasting climatic and land-use regimes : do aliens join the locals or try harder than them? Journal of Ecology 98: 17-27.

Ter Braak, C.J.F. \& Šmilauer, P. 2002. CANOCO reference manual and CanoDraw for Windows user's guide: software for canonical community ordination (version 4.5). Ithaca: Microcomputer Power. Wageningen, NL.

Tichý, L. 2002. JUICE, software for vegetation classification. Journal of Vegetation Science 13: 451-453.

Van der Maarel, E. \& Van der Maarel-Versluys, M. 1996. Distribution and conservation status of littoral vascular plant species along the European coasts. Journal of Coastal Conservation 2: 73-92.

Zohary, M. 1973. Geobotanical foundations of the Middle East. Gustav Fischer Verlag, Stuttgart, DE. 
Chapter 3: Similarity of sand habitats across biogeographical regions | 


\section{Chapter 4}

\section{Distribution of $C 4$ plants in sand habitats of different regions}

Parastoo Mahdavi \& Erwin Bergmeier

Folia Geobotanica, 2017: accepted 
Chapter 3: Similarity of sand habitats across biogeographical regions | 


\section{Abstract}

Sand dunes of warm regions provide suitable habitats for $\mathrm{C} 4$ plants because of improved water and nitrogen use efficiency of $\mathrm{C} 4$ plants under high temperature and high tolerance to ecological stress such as salinity, aridity and disturbance. In this study, we compared the distribution pattern of C4 plant species in sand dune ecosystems of three climatic regions (Mediterranean, Irano-Turanian and Hyrcanian) to find out the proportion and identify habitat preference of $\mathrm{C} 4$ plants in sand habitats. We analyzed the vegetation cover and richness of $\mathrm{C} 4$ and $\mathrm{C} 3$ species in five sand habitats. Our results revealed that $\mathrm{C} 4$ species have notable contribution to the vegetation cover despite of rather low contribution to the richness in comparison with $\mathrm{C} 3$ species. C4 plants were more prominent in mobile dunes, salt marshes and disturbed sandy ground; however, the habitat preference was different in each region. The abundance of $\mathrm{C} 4$ plants appears to be influenced by climatic conditions. We observed a general increasing trend in richness and cover of $\mathrm{C} 4$ plants with increase of aridity. Central Iran is the driest and warmest among our study regions and has the highest proportion of $\mathrm{C} 4$ species in terms of number and cover.

Keywords: C4 pathway, grass, chenopod, biomass, climate, habitat, sand dune, trait, Iran, Greece

\section{Introduction}

C4 photosynthesis is a complex trait, consisting of a combination set of anatomical and biochemical adaptations. It leads to concentration of $\mathrm{CO}_{2}$ around the carbon-fixing enzyme Rubisco and reduction of photorespiration (Sage 2004; Christin \& Osborne 2014). It has evolved independently more than 60 times in 19 families of flowering plants (Sage 2016) and 22-24 times in the Poaceae, the family with the most C4 species (GPWG II 2012). Although C4 species constitute only 3\% of vascular plants, they account for about $25 \%$ of terrestrial primary production (Ehleringer \& Monson 1993; Still et al. 2003). They also include economically important highly productive crops such as maize, sugarcane, sorghum, etc. (Osborne \& Freckleton 2009).

Low partial pressure of atmospheric $\mathrm{CO}_{2}\left(\mathrm{pCO}_{2}\right)$ and high temperature are the main drivers of $\mathrm{C} 4$ evolution and expansion (Ehleringer et al. 1997; Sage 2005; Urban et al. 2015). First lineages of C4 grasses evolved about 30 million years ago, most likely in open habitats of warm regions (Osborne \& Freckleton 2009; Sage 2016). The evolution of the C4 pathway in Chenopodiaceae originated probably from lineages inhabiting saline costal habitats (Kadereit et al. 2012). It has been shown that C4 photosynthesis can extend the ecological niche of plants (Lundgren et al. 2015). This hypothesis contributes to explaining the expansion of $\mathrm{C} 4$ species into a wide range of habitats and biomes (Sage et al. 1999; Christin \& Osborne 2014). Moreover, the present distribution of C4 plants reflects present conditions regardless of changes in $\mathrm{CO}_{2}$ concentration and temperature in the past (Auerswald et al. 2009). 
Chapter 4: Distribution of C4 plants in sand habitats |

The evolutionary, ecological and economical relevance of the $\mathrm{C} 4$ photosynthetic pathway attracted the attention of researchers from different points of view: effects of $\mathrm{C} 4$ plants in the evolution of mammals and humans (van der Merwe \& Tschauner 1999); physiological advantages (Gowik \& Westhoff 2011; Taylor et al. 2014); transgenic C4 crops and biofuels for higher production (Somerville et al. 2010; Lopes et al. 2011; van der Weijde et al. 2013), C4 rice engineering (Kajala et al. 2011; Peterhansel 2011); phylogeny of C4 plants (Edwards et al. 2010; Sage et al. 2011; Christin et al. 2013), and the effect of climate on the distribution of C4 plants (Collatz et al. 1998; Bremond et al. 2012). More than 50 years after the discovery of C4 photosynthesis (Hatch \& Slack 1966), and after intensive researches (reviewed in Sage 2016 and Furbank 2016), the picture is comprehensive but not completed yet. Due to the taxonomical, anatomical and physiological diversity of $\mathrm{C} 4$ groups that evolved along different evolutionary pathways, a variety of ecological, geographical and habitat preferences are concerned. The current distribution of $\mathrm{C} 4$ plants, their ecology in different habitats and regions (especially outside the tropics) as well as $\mathrm{C} 3 / \mathrm{C} 4$ dynamics are not well studied.

Sand dunes are known as stress-prone habitats associated with salinity and drought. Species inhabiting such habitats developed specific traits and adaptations, which enable them to use limited resources. Sand dunes of warm regions are suitable habitats for $\mathrm{C} 4$ plants because of their improved water and nitrogen use efficiency under high temperature (Ehleringer 1978; Long 1999) and high tolerance to ecological stress such as salinity, aridity and disturbance (Sage et al. 1999). The role, abundance and distribution of $\mathrm{C} 4$ plants in sand dunes are not well studied. The distribution of C4 grasses was modeled for West African coasts (Schmidt et al. 2011), and their ecological aspects were investigated in selected habitats of Costa Rica (Chazdon 1978). Outside tropics, floristic surveys showed a high presence of C4 plants in sandy and saline habitats of China and Mongolia (e.g. Pyankov et al. 2000; Wang 2007; Auerswald et al. 2009) . Most ecological studies referred to species richness and neglected abundance (e.g. Pyankov et al. 2010) although the latter is an important issue for ecosystem properties and services.

In this study we compared the distribution pattern of $\mathrm{C} 4$ plant species in three sand dune ecosystems across different climatic regions (Mediterranean, Irano-Turanian and Hyrcanian). In each region we analyzed the $\mathrm{C} 4$ species cover, richness and $\mathrm{C} 3 / \mathrm{C} 4$ ratio in five sand habitats to answer the following: How are $\mathrm{C} 4$ plants distributed in different habitats of sand ecosystems and what are their habitat preferences? Do C4 plants have higher biomass than ecologically similar C3 plants? Do regional climate differences affect the occurrence and proportion of $\mathrm{C} 4$ plants?

\section{Study area}

We studied sand dune ecosystems in three regions (Fig. 1) very different in climate, phytogeography and species composition but similar in their set of psammophytic habitat types. 
NE Greece: the study area along the North Aegean coast runs approximately $300 \mathrm{~km}$ from south of Katerini $\left(40^{\circ} 09^{\prime} \mathrm{N}, 22^{\circ} 33^{\prime} \mathrm{E}\right)$ eastward to Porto Lagos $\left(40^{\circ} 54^{\prime} \mathrm{N}, 25^{\circ} 23^{\prime} \mathrm{E}\right)$. The area is characterized by Mediterranean climate with hot, dry summers and wet and cool winter, almost without frost. Mean monthly temperatures vary between $5-7^{\circ} \mathrm{C}$ (January) and $25-27{ }^{\circ} \mathrm{C}$ (July). Mean annual rainfall is 400 $600 \mathrm{~mm}$ (Lienau 1989).

N Iran: the SE Caspian Sea shore was investigated, including the Miankaleh Biosphere Reserve $\left(36^{\circ} 48\right.$ $\left.55^{\prime} \mathrm{N}, 53^{\circ} 25^{\prime}-54^{\circ} 02^{\prime} \mathrm{E}\right)$ with $50 \mathrm{~km}$ of (semi-)natural coastline, and two other sites westward $\left(36^{\circ} 49^{\prime} \mathrm{N}\right.$, $\left.53^{\circ} 8^{\prime} \mathrm{E}, 36^{\circ} 39^{\prime} \mathrm{N}, 52^{\circ} 22^{\prime} \mathrm{E}\right)$. The area belongs to the Hyrcanian phytogeographic region and is characterized by a warm humid climate with rainy summers and mild winters. The mean temperature of the coldest month (January) is $8.7^{\circ} \mathrm{C}$ and the warmest month is August with mean temperatures of ca. 28 ${ }^{\circ} \mathrm{C}$. The mean annual precipitation is $789 \mathrm{~mm}$ (http://www.chbmet.ir/iranarchive.asp).

Central Iran: the southern shore of the Namak Lake (Daryacheh-ye Namak) in the Maranjab Desert (34 ${ }^{\circ}$ $\left.9-19^{\prime} \mathrm{N}, 51^{\circ} 30-56 ' \mathrm{E}\right)$ is a large saline playa surrounded by sand dunes and saltmarshes. The study sites belong to the Irano-Turanian region, characterized by continental climate, low precipitation, hot and dry summers and cold winters. The mean temperature of the coldest month is ca. $5{ }^{\circ} \mathrm{C}$ (January), while it reaches $33{ }^{\circ} \mathrm{C}$ (July) in the hottest month. The annual precipitation is $136 \mathrm{~mm}$ (http://www.chbmet.ir/iranarchive.asp).

Central Iran has significantly lower precipitation and higher temperature than N Iran (Table 1) as well as NE Greece. This is also reflected by the lower aridity index values of C Iran (Fig. 1). 
Chapter 4: Distribution of C4 plants in sand habitats |
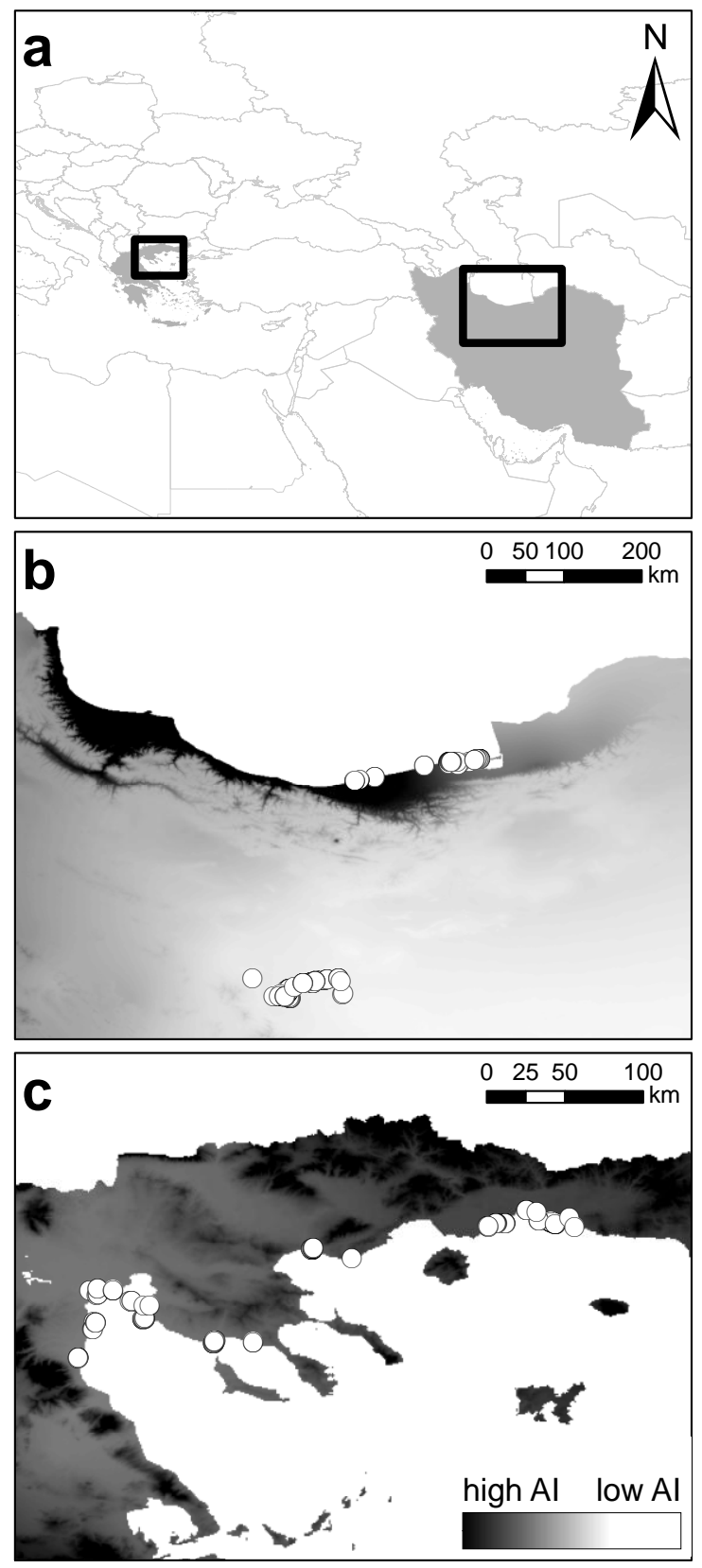

Fig. 1 Overview of the investigated area in Iran and Greece (a) with distribution of sampled plots (open circles) and aridity index (AI) differences between sites: North and Central Iran (b) and NE Greece (c). Low AI and lighter colors represent higher aridity; darker colors and high $\mathrm{AI}$ indicate more humid conditions. 
Chapter 4: Distribution of C4 plants in sand habitats |

\section{Methods}

\section{Data collection}

In total, 317 plots from N Iran (65), C Iran (91) and NE Greece (161) were analyzed. The plots $\left(25 \mathrm{~m}^{2}\right)$ were sampled in summer 2011 and 2012 using the Braun-Blanquet cover/abundance scale for each species in plots of five habitat types where present: mobile dune, stabilized dune, semi-wet habitat (dune slack), salt marsh and disturbed ground. We assigned the regional species pools to the main $\mathrm{C} 3$ and $\mathrm{C} 4$ photosynthetic types chiefly based on the available literature. A list of the recorded $\mathrm{C} 4$ species, the biochemical subtype, and $\mathrm{C} 4$ identification references is provided in Table 1.

Table 1 List of recorded C4 species in the three investigated areas, their subtype and references: 1. (Akhani, Trimborn, \& Ziegler, 1997); 2. (Akhani, Edwards, \& Roalson, 2007); 3. Pyankov et al. 2000; 4. Pyankov et al. 2010; 5. Watson et al. 1992. Subtypes in subfamily Suaedoideae are based on (Muhaidat, Sage, \& Dengler, 2007).

\begin{tabular}{|c|c|c|}
\hline Species & Subtype & Region \\
\hline \multicolumn{3}{|l|}{ Chenopodiacea } \\
\hline Bassia laniflora (S.G. Gmel.) A.J. Scott ${ }^{2}$ & NADP-ME & NE Greece \\
\hline Bassia stellaris (Moq.) Bornm. ${ }^{4}$ & NADP-ME & C Iran \\
\hline Cornulaca aucheri Moq. $^{1}$ & NADP-ME & C Iran \\
\hline Halimocnemis rarifolia (K. Koch) Akhani ${ }^{2}$ & NADP-ME & C Iran \\
\hline Halothamnus subaphyllus (C.A.Mey) Botsch. $^{1}$ & NADP-ME & C Iran \\
\hline Haloxylon ammodendron (C. A. Mey.) Bunge ex Fenzl $\left.\right|^{3}$ & NADP-ME & C Iran \\
\hline Petrosimonia brachiata (Pall.) Bunge ${ }^{4}$ & NAD-ME & N Iran, NE Greece \\
\hline Salsola kali L. ${ }^{4}$ & NADP-ME & C Iran, $\mathrm{N}$ Iran \\
\hline Salsola praecox Litv. $^{2}$ & NADP-ME & C Iran \\
\hline Salsola soda $\mathrm{L}^{4}$ & NADP-ME & NE Greece \\
\hline Salsola tragus $\mathrm{L}^{3}$ & NADP-ME & NE Greece \\
\hline Seidlitzia rosmarinus Ehrenb. ex Boiss. $^{2}$ & NADP-ME & C Iran \\
\hline Sorghum halepense (L.) Pers. ${ }^{4}$ & NADP-ME & NE Greece \\
\hline Suaeda arcuata Bunge ${ }^{1}$ & NAD-ME & C Iran \\
\hline Suaeda fruticosa Forssk. ex J.F. Gmel. ${ }^{1}$ & NAD-ME & C Iran \\
\hline Suaeda splendens (Pourr.) Gren. \& Godr. ${ }^{4}$ & NAD-ME & NE Greece \\
\hline \multicolumn{3}{|l|}{ Poaceae } \\
\hline Aeluropus lagopoides (L.) Trn. ex Thwaites ${ }^{4}$ & NAD-ME & C Iran \\
\hline Aeluropus littoralis (Gouan) Parl. ${ }^{4}$ & NAD-ME & C Iran, NE Greece \\
\hline Bothriochloa pertusa (L.) A. Camus ${ }^{5}$ & & NE Greece \\
\hline Cenchrus incertus M.A. Curtis ${ }^{4}$ & NADP-ME & NE Greece \\
\hline Centropodia forsskalii (Vahl) Cope $^{5}$ & & C Iran \\
\hline Chrysopogon gryllus (L.) Trin. $^{5}$ & & NE Greece \\
\hline Cynodon dactylon (L.) Pers. ${ }^{4}$ & NAD-ME & C Iran, N Iran, NE Greece \\
\hline Digitaria sanguinalis (L.) Scop. ${ }^{4}$ & NADP-ME & NE Greece \\
\hline Echinochloa crus-galli (L.) P. Beauv. $^{3}$ & NADP-ME & NE Greece \\
\hline Eragrostis minor Host $^{3}$ & NAD-ME & NE Greece \\
\hline
\end{tabular}


Chapter 4: Distribution of C4 plants in sand habitats |

\begin{tabular}{|c|c|c|}
\hline Species & Subtype & Region \\
\hline Imperata cylindrica (L.) Raeusch. $^{4}$ & NADP-ME & N Iran, NE Greece \\
\hline Paspalum distichum L. ${ }^{4}$ & NADP-ME & N Iran, NE Greece \\
\hline Saccharum griffithii Munro ex Aitch. $^{5}$ & NADP-ME & N Iran \\
\hline Saccharum ravennae (L.) L. ${ }^{4}$ & NADP-ME & N Iran, NE Greece \\
\hline Saccharum spontaneum L. ${ }^{4}$ & NADP-ME & N Iran \\
\hline Setaria verticillata (L.) P.Beauv. ${ }^{4}$ & NADP-ME & NE Greece \\
\hline Sporobolus pungens (Schreb.) Kunth ${ }^{4}$ & & NE Greece \\
\hline Stipagrostis barbata H. Scholz ${ }^{5}$ & NADP-ME & C Iran \\
\hline Stipagrostis karelinii (Trin. \& Rupr.) H. Scholz ${ }^{4}$ & NADP-ME & C Iran \\
\hline Stipagrostis pennata (Trin.) De Winter ${ }^{4}$ & NADP-ME & C Iran \\
\hline Stipagrostis plumosa (L.) Munro ex T. Anderson ${ }^{5}$ & NADP-ME & C Iran \\
\hline Tragus racemosus (L.) All. $^{4}$ & NAD-ME & N Iran \\
\hline \multicolumn{3}{|l|}{ Other families } \\
\hline Cyperus capitatus Vand. $^{4}$ & NADP-ME & NE Greece \\
\hline Cyperus eremicus Kukkonen & & CIran \\
\hline Cyperus rotundus $\mathrm{L}^{4}$ & NADP-ME & NE Greece \\
\hline Euphorbia peplis L. ${ }^{4}$ & NADP-ME & NE Greece \\
\hline Mollugo cerviana (L.) Ser. ${ }^{3}$ & NAD-ME & NE Greece \\
\hline Calligonum crinitum Boiss. $^{3}$ & NAD-ME & C Iran \\
\hline Calligonum polygonoides L. ${ }^{3}$ & NAD-ME & C Iran \\
\hline Portulaca oleracea L. ${ }^{3}$ & NAD-ME & NE Greece \\
\hline Tribulus terrestris L. ${ }^{3}$ & NADP-ME & C Iran, N Iran, NE Greece \\
\hline
\end{tabular}

\section{Data analysis}

In order to assess the proportion of $\mathrm{C} 4$ plants in different sand habitats, the $\mathrm{C} 4$ cover proportion was calculated by summing up the percentage cover (transformed cover/abundance scale values) of C4 plants in each plot. We used the percentage cover of species by proxy for aboveground biomass. Standardized percentage values of species per habitat and region were displayed using boxplots (Tableau, https://www.tableau.com). The significance of observed differences between habitats was tested using non-parametric Kruskal-Wallis test (R, stats package, Hollander \& Wolfe 1973).

Further, we calculated the $\mathrm{C} 4 / \mathrm{C} 3$ ratio for both species richness and percentage cover across habitats and regions, to assess the dominance and biomass of $\mathrm{C} 4$ plants compared to $\mathrm{C} 3$ species.

Climate data including mean annual temperature and precipitation sums were taken from CHELSA (Karger et al. 2016 a \& b, www.chelsa-climate.org) and aridity index from CGIAR-CSI (Zomer et al. $2007 \&$ 2008, www.cgiar-csi.org). The according values for each plot were extracted in ArcGIS 10.4 (ESRI 2011) and mean values calculated per region. 


\section{Results}

\section{Distribution of $\mathrm{C} 4$ plants in different habitats}

The total number of $\mathrm{C} 4$ plants in $\mathrm{C}$ Iran $(32 \%, 23 \mathrm{C} 4$ species/72 species in total, based on the whole sample of 91 plots) was higher than in N Iran (14\%, 10/72 species, 65 plots) and NE Greece (12\%, 25/211 species, 161 plots). Based on species rank abundance curve (not shown), the first region was dominated by C4 species such as Cyperus eremicus, Seidlitzia rosmarinus, Stipagrostis plumosa and tall shrubs of Haloxylon ammodendron and Calligonum spp. In N Iran, C4 species of semi-wet habitats were frequent: Saccharum ravennae and Imperata cylindrica. Aeluropus littoralis and Imperata cylindrica were common in NE Greece. The highest C4 record was among monocots with 22 species of Poaceae and 3 species of Cyperaceae. Among dicots, Chenopodiaceae had most C4 records (16 species) and 7 species were found from other dicot families.

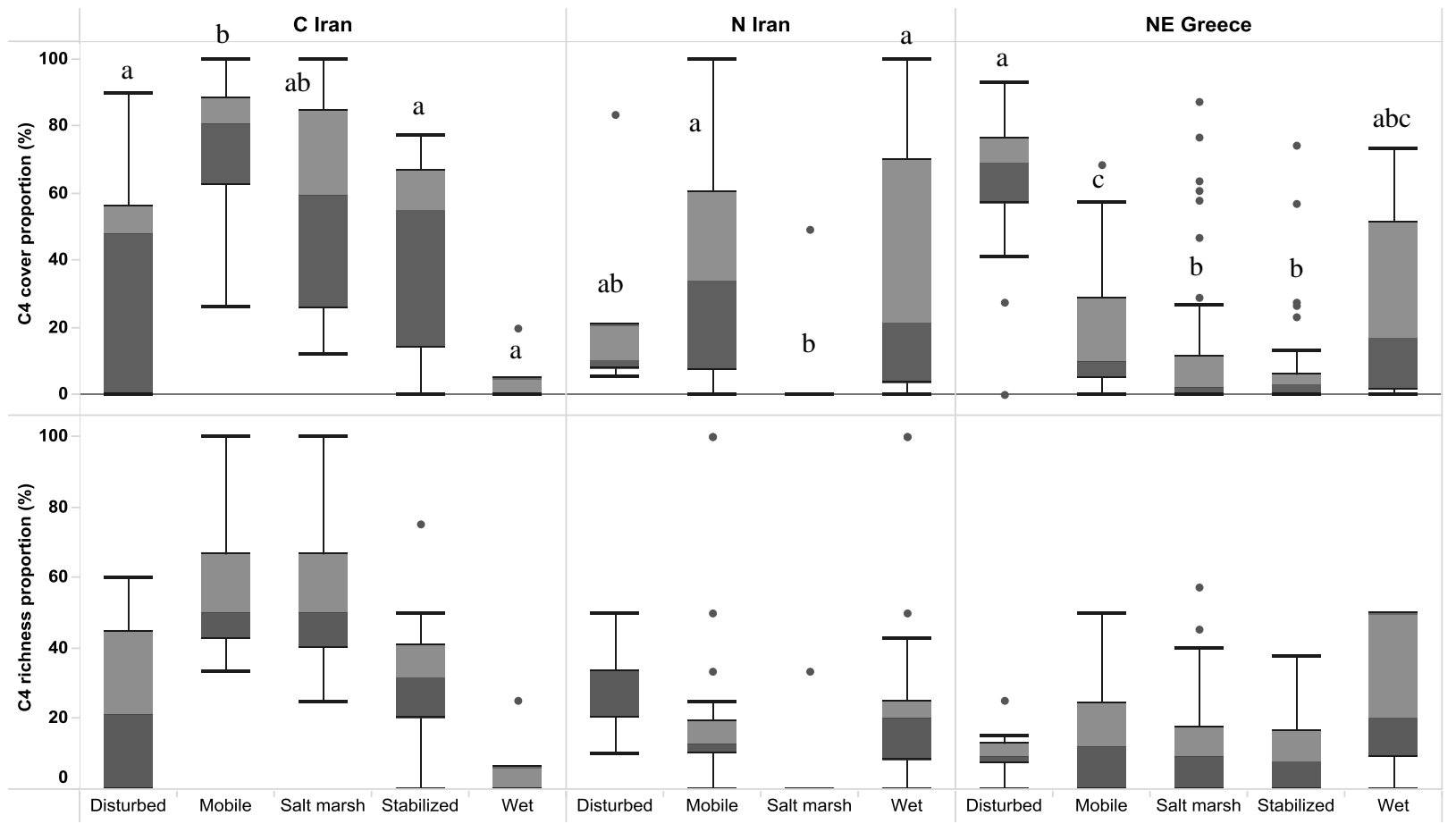

Fig 2. Boxplots of richness and cover proportion of $\mathrm{C} 4$ species in sand dune habitats of three regions. Boxes show the upper (light grey) and lower Quartile (dark grey), border of grey blocks represent the median, whiskers represent the maximum and minimum values and individual points are outliers. Letters indicate significant differences between habitats according to Kruskal-Wallis test $(\mathrm{P}<0.001)$. 
Chapter 4: Distribution of C4 plants in sand habitats |

The highest $\mathrm{C} 4$ richness (species number per plot) was recorded in disturbed sandy sites of $\mathrm{N}$ Iran and semi-wet habitats of NE Greece while in C Iran the highest numbers of C4 species occurred in mobile dunes and salt marshes (Fig. 2). Fixed dunes and saltmarshes in NE Greece, saltmarshes in N Iran and semi-wet habitats in C Iran showed the least C4 species records.

In terms of cover, the habitat preferences of C4 plants were different. In $\mathrm{N}$ and $\mathrm{C}$ Iran, $\mathrm{C} 4$ plants had the highest cover proportion in mobile dunes, followed by semi-wet habitats and salt marshes respectively (Fig. 2). In NE Greece, C4 plants were most abundant in disturbed habitats (Fig. 2).

Although richness of $\mathrm{C} 4$ species in sand habitats was in general lower than (or equal to) that of $\mathrm{C} 3$ plants, C4 plants have quite high cover. The mean C4 plant cover per plot in C Iran is about $61 \%$ corresponding to $50 \%$ of $\mathrm{C} 4$ species richness per plot. High cover of $\mathrm{C} 4$ plants is even more prominent in NE Greece, where $18 \% \mathrm{C} 4$ plant cover is generated from only $0.1 \%$ of $\mathrm{C} 4$ plant richness per plot. In N Iran, C4 plants cover $30 \%$ per plot while their richness is $19 \%$ (Table 2).

Although richness of $\mathrm{C} 4$ species in sand habitats was in general lower than (or equal to) that of $\mathrm{C} 3$ plants, $\mathrm{C} 4$ plants have quite high cover. The mean $\mathrm{C} 4$ plant cover per plot in $\mathrm{C}$ Iran is about $61 \%$ corresponding to $50 \%$ of $\mathrm{C} 4$ species richness per plot. High cover of $\mathrm{C} 4$ plants is even more prominent in NE Greece, where $18 \% \mathrm{C} 4$ plant cover is generated from only $0.1 \%$ of $\mathrm{C} 4$ plant richness per plot. In $\mathrm{N}$ Iran, $\mathrm{C} 4$ plants cover $30 \%$ per plot while their richness is $19 \%$ (Table 2).

Table 2 Differences in climatic parameters between regions and average values of richness and cover proportion for C4 plants in each region (plot-based calculation).

\begin{tabular}{ll|lcr}
\hline Region & & C Iran & N Iran & Greece \\
\hline Number of plots per region $(\mathbf{n})$ & & 89 & 65 & 161 \\
\hline \multirow{2}{*}{ Richness proportion C4 species } & Mean & 49.7 & 18.8 & 0.1 \\
& Min & 0.0 & 0.0 & 0.0 \\
& Max & 100.0 & 100.0 & 0.6 \\
\hline \multirow{2}{*}{ Cover proportion C4 species } & Mean & 60.8 & 30.0 & 18.2 \\
& Min & 0.0 & 0.0 & 0.0 \\
& Max & 100.0 & 100.0 & 93.1 \\
\hline \multirow{3}{*}{ Aridity index } & Mean & 712.1 & 5151.3 & 4303.4 \\
& Min & 585.0 & 3754.0 & 3668.0 \\
& Max & 802.0 & 8089.0 & 5223.0 \\
\hline \multirow{3}{*}{ Mean annual temperature [ $\left.{ }^{\circ} \mathrm{C}\right]$} & Mean & 20.6 & 17.9 & 16.2 \\
& Min & 18.3 & 16.9 & 15.3 \\
& Max & 21.1 & 18.7 & 16.7 \\
\hline \multirow{2}{*}{ Mean annual precipitation [mm] } & Mean & 139.7 & 494.9 & 490.6 \\
& Min & 114.3 & 384.7 & 378.5 \\
& Max & 179.5 & 729.2 & 657.1 \\
\hline \multicolumn{4}{r}{}
\end{tabular}




\section{$\mathrm{C4} / \mathrm{C} 3$ richness and cover ratio in comparison}

The richness and cover ratio of $\mathrm{C} 4$ and $\mathrm{C} 3$ species provides further insight to dominance and distribution of C4 plants in different sand habitats. In saltmarshes of C Iran, richness and cover ratios had a similar value (ratio of 1) which means an equal proportion of C3 and C4 species in terms of number and cover. In mobile dunes, cover proportion of $\mathrm{C} 4$ plants was more than three times as that of $\mathrm{C} 3$ plants although they had the same number of species. Richness of C4 species was $40 \%$ of that of $\mathrm{C} 3$ species in both disturbed sites and stabilized dunes although the cover proportion of $\mathrm{C} 4$ plants was $90 \%$ of that of $\mathrm{C} 3$ plants in stabilized dunes and $75 \%$ in disturbed habitats. The lowest proportion of C4 plants occurred in semi-wet habitats, where richness and cover was $10 \%$ of that of C3 species (Table 3 ).

In $\mathrm{N}$ Iran, although the number of $\mathrm{C} 4$ species in mobile dunes was only $15 \%$ of $\mathrm{C} 3$ species numbers, $\mathrm{C} 4$ plants produced the same cover as C3 plants. C4 plants had also quite high cover in semi-wet habitats (70\% of $\mathrm{C} 3$ species), while their richness was $20 \%$ of that of $\mathrm{C} 3$ species. In disturbed habitats, richness and cover proportion of $\mathrm{C} 4$ species were $30 \%$ of that of $\mathrm{C} 3$ species. The lowest richness and cover ratio was recorded in saltmarshes where $\mathrm{C} 4$ species occurred to less than $10 \%$ of $\mathrm{C} 3$ species (Table 3).

In NE Greece, richness ratios were generally low but $\mathrm{C} 4$ species had significant cover in disturbed habitats. While the richness of $\mathrm{C} 4$ species was about one third of that of $\mathrm{C} 3$ species, the cover was nearly two times of that of $\mathrm{C} 3$ species (1.85). In semi-wet habitats there were much fewer $\mathrm{C} 4$ species (richness ratio of 0.13 ) but their cover was $36 \%$ of that of $\mathrm{C} 3$ species (Table 3). Richness and cover ratios were almost equal in the other coastal sand habitats of NE Greece.

Table 3 Richness and cover ratio in sandy habitats of three study regions.

\begin{tabular}{rr|rrrrrr}
\hline \multicolumn{2}{c}{ Habitat } & Dist & Mob. & Salt. & Satb. & Wet & Total \\
\hline \multirow{2}{*}{ C Iran } & C4/C3 richness & 0.37 & 0.98 & 0.97 & 0.42 & 0.13 & 0.75 \\
& C4/C3 cover & 0.75 & 3.34 & 1.04 & 0.92 & 0.11 & 0.88 \\
\hline \multirow{2}{*}{ N Iran } & C4/C3 richness & 0.30 & 0.15 & 0.03 & - & 0.21 & 0.18 \\
& C4/C3 cover & 0.26 & 1.01 & 0.08 & - & 0.68 & 0.43 \\
\hline \multirow{2}{*}{ NE Greece } & C4/C3 richness & 0.30 & 0.20 & 0.15 & 0.05 & 0.13 & 0.14 \\
& C4/C3 cover & 1.85 & 0.21 & 0.14 & 0.11 & 0.36 & 0.37 \\
\hline
\end{tabular}


Chapter 4: Distribution of C4 plants in sand habitats |

\section{Discussion}

\section{Distribution in sand habitats}

We found notable presence of $\mathrm{C} 4$ plants in terms of vegetation cover in mobile dunes, saltmarshes and disturbed sandy ground, despite of their low number of species. At least in some habitats, the conditions for $\mathrm{C} 4$ plant dominance are favorable. This result is in consistence with a general trend for $\mathrm{C} 4$ plants to occur in hot, arid, saline and disturbed habitats (Ehleringer \& Monson 1993). Relative high abundance of C4 species in sandy and saline habitats was observed as well in deserts of China (Wang 2007; Su et al. 2011).

Mobile dunes are more than other sand habitats subjected to water and nutrient shortage (Maun 2009). Nutrient and water use efficiency of C4 plants are well reflected in mobile sands in deserts of C Iran dominated by tall $\mathrm{C} 4$ shrubs of Calligonum crinitum and Haloxylon ammodendron forming communities on shifting dunes, and C4 graminoid communities such as of Stipagrostis plumosa, S. karelinii, S. pennata and Cyperus eremicus (Mahdavi et al. in press). In low-nutrient habitats $\mathrm{C} 4$ plants may use the nitrogen sources for developing the root system while the leaf area equals that of the C3 species (Christin \& Osborne 2014). Biomass allocation in roots can be well observed in Calligonum and Haloxylon with thick, long and well developed root system but with reduced or no leaf system, adapted to the dry and nutrientpoor conditions of sandy soils.

Salinity stress is associated with limited water availability and drought adaptation and may have promoted the evolution of C4 halophytes (Sage 2005; Kadereit et al. 2012). Some C4 halophytes occur on extremely saline soils where no C3 halophytes can survive. (Kadereit et al. 2012) suggested that C4 lineages in Chenopodiaceae derived from C3 ancestors already adapted to saline/dry habitats. Given the current distribution and dominance of chenopods in diverse arid deserts, steppes and saline habitats, such preadaptation for shifting from coastal sites into dryer steppes and deserts is considered essential (Kadereit et al. 2012). In our study, the high presence of $C 4$ species in saltmarshes of $C$ Iran in terms of number and cover is evident (Fig. 2). Communities of Seidlitzia rosmarinus in C Iran and of Aeluropus littoralis in all three regions are examples of $\mathrm{C} 4$ vegetation in salt marshes (Mahdavi et al. in press).

Disturbed habitats are known for being inhabited by many C4 species (Collins \& Jones 1985; Čarni \& Mucina 1998). Disturbance influences the dynamics and expansion of C4 plants. It creates open habitats favorable to shade-intolerant C4 plants (Sage et al. 1999). C4 species in fertile and/or disturbed habitats may use the same amount of nitrogen to produce a larger leaf area than their C3 relatives (Christin \& Osborne 2014). Plants in disturbed habitats grow rapidly and have short life histories to withstand unfavorable conditions. Therefore, the nitrogen use efficiency of $\mathrm{C} 4$ plants and the potential of high 
biomass production is an advantage in disturbed habitats. It explains the high $\mathrm{C} 4$ cover proportion of disturbed sandy grounds observed in our study. $\mathrm{C} 4$ plants have significant presence in disturbed habitats of NE Greece in terms of cover and of N Iran in terms of richness.

In both coastal regions of N Iran and NE Greece, there are patches of semi-wet habitats between mobile dunes inhabited by tall and dense clonal colonies of Saccharum spp. and Imperata cylindrica, which unlike other $\mathrm{C} 4$ species do not occur in dry habitats.

In general, we found that $\mathrm{C} 4$ abundance differed in the same habitat in different regions. However, the pattern in NE Greece and N Iran was more similar, probably due to higher climatic similarity of the two regions. Different habitat preference of $\mathrm{C} 4$ plants across regions may be partly due to climatic differences between regions and partly due to variation in $\mathrm{C} 4$ groups including different biochemical and anatomical subtypes, different lineages of $\mathrm{C} 4$ plants and taxonomic differences (monocots vs. dicots) which is resulted in different ecophysiological response to regional environmental conditions. Previously, we defined seven main functional groups in sand dunes by analyzing the functional traits of plants (Mahdavi \& Bergmeier 2016). Three of them include C4 species: Shrubs, perennial graminoids and annual succulents. Each group, characterized by a set of traits common to both $\mathrm{C} 3$ and $\mathrm{C} 4$ species, indicates similar adaptations and niche preferences. It confirms that habitat preferences of $\mathrm{C} 4$ species are not only due to their photosynthetic pathway, but also connected to other traits inherited from their $\mathrm{C} 3$ ancestors (Christin \& Osborne 2014).

\section{C4 abundance and biomass}

Our results revealed that $\mathrm{C} 4$ species contribute most notably to the vegetation cover and less to the richness in comparison to $\mathrm{C} 3$ species (Table 3). This pattern was more pronounced in the drier region (C Iran), where higher $\mathrm{C} 4$ cover and species numbers were observed. In some habitats, $\mathrm{C} 4$ plants even stand out in cover percentage against more species-rich $\mathrm{C} 3$ plants. High $\mathrm{C} 4$ cover proportion may be related to high individual biomass and/or because of the large population of some species. Similar results were obtained in the USA Central Plains Experimental Range, where 59\% of the species were C3 but account for only $10 \%$ of the biomass (Paruelo \& Lauenroth 1996).

It was shown that improved water and nitrogen use efficiency in C4 plants may enhance biomass allocation in C4 species, but productivity varies depending on environments (Ehleringer \& Monson 1993; Long 1999; Christin \& Osborne 2014). According to the crossover temperature hypothesis (Ehleringer 1978; Ehleringer et al. 1997), C3 grasses are competitive and dominant when daytime growing season temperatures are below $22^{\circ} \mathrm{C}$. $\mathrm{C} 4$ grasses are dominant at temperatures above $30^{\circ} \mathrm{C}$. (Winslow et al. 2003) argued that seasonal access to available water controls the relative $\mathrm{C} 3$ and $\mathrm{C} 4$ grass biomass. In this case, temperature causes temporal separation of the growing peaks of grasses where at high temperature (late 
Chapter 4: Distribution of C4 plants in sand habitats |

summer) almost only C4 grasses have access to water and at lower temperature (early summer) C3 grasses. Water use efficiency of $\mathrm{C} 4$ plants is an advantage when water availability is limited. Most C4 species in our regions are late flowering plants and complete their life cycle in late summer when it is too dry for most C3 plants and their growing period is already over. The average summer temperature in our study regions is above the crossover temperature.

Furthermore, biomass allocation varies in different C4 groups. Taylor et al. (2010) showed that biomass allocation is greater in the NADP-ME C4 grass subtype than in other subtypes and C3 species. They discovered a distinct shift in biomass allocation and physiology associated with phylogenetic divergence between the grass tribe Paniceae and other PACMAD lineages (Panicoideae, Arundinoideae, Chloridoideae, Micrairoideae, Aristidoideae and Danthonioideae), suggesting the phylogenetic influence of different C4 lineages and their C3 ancestors on the ecological behavior of C4 plants (Christin \& Osborne 2014). While our study cannot determine the share of each C4 group or lineage in the obtained results or specify the biomass strategy of $\mathrm{C} 4$ pants (shoot/root ratio), it confirmed the previous hypothesis that C4 plants have the potential of higher productivity in comparison to ecologically similar and cooccurring C3 plants (Still et al. 2003).

\section{C4 proportion and climatic parameter}

While the number of studied regions was limited we observed a general increasing trend in richness and cover of C4 species with increasing aridity (lower value of aridity index) (Table 1). C Iran, the driest and warmest study region (highest mean temperature, lowest precipitation and lowest aridity index) has the highest proportion of $\mathrm{C} 4$ species, indicating that regional climate affects the proportion of $\mathrm{C} 4$ plants.

Among climatic parameters, temperature is strongly positively correlated with $\mathrm{C} 4$ species richness and biomass (Sage et al. 1999). Bremond et al. (2012) showed that mean annual temperature is the best predictor of $\mathrm{C} 4$ grass proportion in Neotropical Andes. The same result has been reported to explain the distribution of C4 species in Europe (Collins \& Jones 1985). In the more recent work, Pyankov et al. (2010) indicated that the total abundance of C4 species in Europe is positively correlated with aridity. Furthermore, they showed that different groups of $\mathrm{C} 4$ species respond differently in respect to temperature and precipitation; e.g. the abundance of total $\mathrm{C} 4$ monocots were correlated with temperature whereas $\mathrm{C} 4$ dicots with precipitation. Even grasses of different biochemical subtypes of C4 photosynthesis (NAD-ME, NADP-ME or PCK) may have different distribution patterns (Ehleringer et al. 1997), whereby NAD-ME C4 grasses dominate drier regions. Duffy \& Chown (2016) correlated the relative abundance of C4 species with the urban warming and showed that local increased temperature in cities of Europe favors $\mathrm{C} 4$ species. Competitive advantage of $\mathrm{C} 4$ plants and their higher diversification in warm, dry and open environments was shown in previous studies (Long 1999; Bouchenak-Khelladi et al. 2014). However, the current 
distribution of $\mathrm{C} 4$ plants in warm and dry climates is not only due to the evolution of the photosynthetic type but could be the heritage of their C3 ancestors and subfamilies (Taub 2000; Edwards \& Still 2008). It has been shown that the distribution of $\mathrm{C} 3$ and $\mathrm{C} 4$ grasses in Hawaii is linked with the distribution pattern of Pooideae (only C3 species) and the more thermophilous PACMAD lineage (both C3 and C4 species) and it is not only due to photosynthetic pathway as the latter lineage preferred warmer climates (Edwards \& Still 2008). Nevertheless, they suggest that the C4 pathway may fix the ecological role of C4 plants as warm climate specialist. These findings emphasize that considering C4 plants as one group, without taking into consideration their phylogeny and functional variation (e.g. monocots vs. dicots, C4 subtypes, etc.) may lead to misinterpretation of the observed patterns.

\section{Conclusion}

Mediterranean, Hyrcanian and Irano-Turanian sand ecosystems with high summer temperature, intensive light, nutrient poor soils and dry condition are suitable places for inhabiting C4 plants. Physiological and morphological advantages of $\mathrm{C} 4$ plants lead to $\mathrm{C} 4$ plant dominance in mobile dunes, saltmarshes and disturbed sandy grounds. We found that $\mathrm{C} 4$ plants are more prominent in dry regions and that the regional climate may affect the proportion of $\mathrm{C} 4$ plants. The contribution of $\mathrm{C} 4$ species to total vegetation cover is shown to be important in ecological studies of $\mathrm{C} 4$ distribution as the number of species alone may not fully explain the role of $\mathrm{C} 4$ plants in a given area. We suggest including other plant traits in addition to the photosynthetic pathway. Joint ecological, physiological and evolutionary approaches will be fruitful for a comprehensive understanding of $\mathrm{C} 4$ plants.

\section{Acknowledgment}

We would like to thank the Reinhold-und-Johanna-Tüxen-Stiftung for funding the field work in Iran for P.M. Special thanks to Dr. Inga Schmiedel for her help for producing the map of the study area. 
Chapter 4: Distribution of C4 plants in sand habitats |

\section{References}

Akhani, H., Edwards, G.E., \& Roalson, E.H. 2007. Diversification of the Old World Salsoleae s.l. (Chenopodiaceae): Molecular Phylogenetic Analysis of Nuclear and Chloroplast Data Sets and a Revised Classification. International Journal of Plant Sciences 168: 931-956.

Akhani, H., Trimborn, P., \& Ziegler, H. 1997. Photosynthetic pathways inChenopodiaceae from Africa, Asia and Europe with their ecological, phytogeographical and taxonomical importance. Plant Systematics and Evolution 206: 187-221.

Auerswald, K., Wittmer, M.H.O.M., Männel, T.T., Bai, Y.F., Schäufele, R., \& Schnyder, H. 2009. Large regional-scale variation in $\mathrm{C} 3 / \mathrm{C} 4$ distribution pattern of Inner Mongolia steppe is revealed by grazer wool carbon isotope composition. Biogeosciences 6: 795-805.

Bouchenak-Khelladi, Y., Muasya, A.M., \& Linder, H.P. 2014. A revised evolutionary history of Poales: Origins and diversification. Botanical Journal of the Linnean Society 175: 4-16.

Bremond, L., Boom, A., \& Favier, C. 2012. Neotropical C3/C4 grass distributions - present, past and future. Global Change Biology 18: 2324-2334.

Čarni, A., \& Mucina, L. 1998. Vegetation of trampled soil dominated by C4 plants in Europe. Journal of Vegetation Science 9: 45-56.

Chazdon, R.L. 1978. Ecological Aspects of the Distribution of C4 Grasses in Selected Habitats of Costa Rica. Biotropica 10: 265-269.

Christin, P.-A., \& Osborne, C.P. 2014. The evolutionary ecology of C4 plants. New Phytologist 204: 765781.

Christin, P.-A., Osborne, C.P., Chatelet, D.S., Columbus, J.T., Besnard, G., Hodkinson, T.R., Garrison, L.M., Vorontsova, M.S., \& Edwards, E.J. 2013. Anatomical enablers and the evolution of C4 photosynthesis in grasses. Proceedings of the National Academy of Sciences of the United States of America 110: 1381-6.

Collatz, G.J., Berry, J. A., \& Clark, J.S. 1998. Effects of climate and atmospheric $\mathrm{CO}_{2}$ partial pressure on the global distribution of C4 grasses: present, past, and future. Oecologia 114: 441-454.

Collins, R.P., \& Jones, M.B. 1985. The influence of climatic factors on the distribution of C4 species in Europe. Vegetatio 64: 121-129.

Duffy, G.A., \& Chown, S.L. 2016. Urban warming favours C4 plants in temperate European cities. Journal of Ecology 104: 1618-1626. 
Edwards, E.J., Osborne, C.P., Strömberg, C. a E., Smith, S. a, Bond, W.J., Christin, P.-A., Cousins, A.B., Duvall, M.R., Fox, D.L., Freckleton, R.P., Ghannoum, O., Hartwell, J., Huang, Y., Janis, C.M., Keeley, J.E., Kellogg, E. a, Knapp, A.K., Leakey, A.D.B., Nelson, D.M., Saarela, J.M., Sage, R.F., Sala, O.E., Salamin, N., Still, C.J., \& Tipple, B. 2010. The origins of C4 grasslands: integrating evolutionary and ecosystem science. Science (New York, N.Y.) 328: 587-91.

Edwards, E.J., \& Still, C.J. 2008. Climate, phylogeny and the ecological distribution of C4 grasses. Ecology letters 11: 266-76.

Ehleringer, J.R. 1978. Implications of Quantum yield differences on the distribution of C3 and C4 grasses. Oecologia 31: 255-267.

Ehleringer, J.R., Cerling, T.E., \& Helliker, B.R. 1997. C4 photosynthesis, atmospheric $\mathrm{CO}_{2}$ and climate. Oecologia 112: 285-299.

Ehleringer, J.R., \& Monson, R.K. 1993. Evolutionary and Ecological Aspects of Photosynthetic Pathway Variation. Annual Review of Ecology and Systematics 24: 411-439.

ESRI 2011. ArcGIS Desktop: Release 10. Redlands, CA: Environmental Systems Research Institute.

Furbank, R.T. 2016. Walking the C4 pathway: Past, present, and future. Journal of Experimental Botany 67: 4057-4066.

Gowik, U., \& Westhoff, P. 2011. The path from C3 to C4 photosynthesis. Plant physiology 155: 56-63.

Grass Phylogeny Working Group II 2012. New grass phylogeny resolves deep evolutionary relationships and discovers C4 origins. New Phytol 193: 304-312.

Hatch M.D., Slack C.R. 1966. Photosynthesis by sugar-cane leaves-a new carboxylation reaction and pathway of sugar formation. Biochemical Journal 101: 103-111.

Hollander M. \& Wolfe D.A. 1973. Nonparametric Statistical Methods. New York: John Wiley \& Sons.

Kadereit, G., Ackerly, D., \& Pirie, M.D. 2012. A broader model for $\mathrm{C}_{4}$ photosynthesis evolution in plants inferred from the goosefoot family (Chenopodiaceae s.s.). Proceedings. Biological sciences / The Royal Society 279: 3304-11.

Kajala, K., Covshoff, S., Karki, S., Woodfield, H., Tolley, B.J., Dionora, M.J. a, Mogul, R.T., Mabilangan, A.E., Danila, F.R., Hibberd, J.M., \& Quick, W.P. 2011. Strategies for engineering a two-celled C4 photosynthetic pathway into rice. Journal of experimental botany 62: 3001-10.

Karger, D.N., Conrad, O., Böhner, J., Kawohl, T., Kreft, H., Soria-Auza, R.W., Zimmermann, N.E., Linder, H.P. \& Kessler, M. 2016. Climatologies at high resolution for the Earth land surface areas. arXiv:1607.00217 [physics]. 
Chapter 4: Distribution of C4 plants in sand habitats |

Karger, D.N., Conrad, O., Böhner, J., Kawohl, T., Kreft, H., Soria-Auza, R.W., Rodrigo, W., Zimmermann, N.E., Linder, H.P., \& Kessler, M. 2016. CHELSA climatologies at high resolution for the earth's land surface areas (Version 1.1). World Data Center for Climate.

Lienau, C. 1989. Griechenland. Geographie eines Staates der Europäischen Südperipherie. Darmstadt : Wissenschaftliche Buchgesellschaft.

Long, S.P. 1999. Environmental responses. In: Sage, R.F., Monson, R.K., eds. C4 Plant Biology. 215-249. Toronto: Academic Press.

Lopes, M.S., Araus, J.L., van Heerden, P.D.R., \& Foyer, C.H. 2011. Enhancing drought tolerance in C4 crops. Journal of experimental botany 62: 3135-53.

Lundgren, M.R., Besnard, G., Ripley, B.S., Lehmann, C.E.R., Chatelet, D.S., Kynast, R.G., Namaganda, M., Vorontsova, M.S., Hall, R.C., Elia, J., Osborne, C.P., \& Christin, P.A. 2015. Photosynthetic innovation broadens the niche within a single species. Ecology Letters 18: 1021-1029.

Mahdavi, P., \& Bergmeier, E. 2016. Plant functional traits and diversity in sand dune ecosystems across different biogeographic regions. Acta Oecologica 74: 37-45.

Mahdavi, P.M., Isermann, M. \& Bergmeier, E. 2017. Sand habitats across biogeographical regions at species, community and functional level. Phytocoenologia, in press.

Maun, A.M. 2009. The biology of Coastal Sand Dunes. Oxford University press.

van der Merwe, N.J., Tschauner, H. 1999. C4 plants and the development of human societies. In: Sage, R.F., Monson, R.K., eds. C4 Plant Biology. 509-549. Toronto: Academic Press.

Muhaidat, R., Sage, R.F., \& Dengler, N.G. 2007. Diversity of Kranz anatomy and biochemistry in C4 eudicots. American Journal of Botany 94: 362-381.

Osborne, C.P., \& Freckleton, R.P. 2009. Ecological selection pressures for C4 photosynthesis in the grasses. Proceedings. Biological sciences / The Royal Society 276: 1753-60.

Paruelo J.M., Lauenroth, W.K. 1996. Relative abundance of plant functional types in grasslands and shrublands of North America. Ecol. Appl. 6: 1212-1224.

Peterhansel, C. 2011. Best practice procedures for the establishment of a C4 cycle in transgenic C3 plants. Journal of experimental botany 62: 3011-9.

Pyankov, V.I., Gunin, P.D., Tsoog, S., \& Black, C.C. 2000. C4 plants in the vegetation of Mongolia: their natural occurrence and geographical distribution in relation to climate. Oecologia 123: 15-31.

Pyankov, V.I., Ziegler, H., Akhani, H., Deigele, C., \& Lüttge, U. 2010. European plants with C4 
photosynthesis: geographical and taxonomic distribution and relations to climate parameters. Botanical Journal of the Linnean Society 163: 283-304.

Sage, R.F. 2016. A portrait of the C4 photosynthetic family on the 50th anniversary of its discovery: Species number, evolutionary lineages, and Hall of Fame. Journal of Experimental Botany 67: 40394056.

Sage, R.F. 2005. Atmospheric $\mathrm{CO}_{2}$, Environmental Stress, and the Evolution of C4 Photosynthesis. In $A$ History of Atmospheric $\mathrm{CO}_{2}$ and its Effects on Plants, Animals and Ecosystems, pp. 185-213. Springer, New York.

Sage, R.F. 2004. The evolution of C4 photosynthesis. New Phytologist 161: 341-370.

Sage, R.F., Christin, P.-A., \& Edwards, E.J. 2011. The C4 plant lineages of planet Earth. Journal of experimental botany 62: 3155-69.

Sage, R.F., Wedin, D.A. \& Meirong, L. 1999. The biogeography of C4 photosynthesis: patterns and controlling factors. In: Sage, R.F., Monson, R.K., eds. C4 Plant Biology. 313-373. Toronto: Academic Press.

Sage, R.F. \& Monson, R.K. 1999. C4 Plant Biology. Toronto: Academic Press.

Schmidt, M., König, K., Müller, J. V, Brunken, U., \& Zizka, G. 2011. Modeling the distribution of photosynthetic types of grasses in Sahelian Burkina Faso with high-resolution satellite data. Ecotropica 17: 53-63.

Somerville, C., Youngs, H., Taylor, C., Davis, S.C. \& Long, S.P. 2010. Feedstocks for lignocellulosic biofuels. Science 329: 790-792.

Still, C.J., Berry, J.A., Collatz, G.J., \& Defries, R.S. 2003. Global distribution of C3 and C4 vegetation : Carbon cycle implications. Global Biogeochemical Cycles 17:.

Su, P., Xie, T., \& Zhou, Z. 2011. C4 plant species and geographical distribution in relation to climate in the desert vegetation of China. Sciences in Cold and Arid Regions 3: 381-391.

Taub, D.R. 2000. Climate and the U.S. Distribution of C4 Grass Subfamilies and Decarboxylation Variants of C4 Photosynthesis. American journal of botany 87: 1211-1215.

Taylor, S.H., Hulme, S.P., Rees, M., Ripley, B.S., Woodward, F.I., \& Osborne, C.P. 2010. Ecophysiological traits in C3 and C4 grasses: a phylogenetically controlled screening experiment. The New phytologist 185: 780-91.

Taylor, S.H., Ripley, B.S., Martin, T., De-Wet, L.A., Woodward, F.I., \& Osborne, C.P. 2014. Physiological advantages of $\mathrm{C} 4$ grasses in the field: A comparative experiment demonstrating the 
Chapter 4: Distribution of C4 plants in sand habitats |

importance of drought. Global Change Biology 20: 1992-2003.

Urban, M.I.A., Elson, D.A.M.N., Errott, F.A.L.S.T., \& Erschuren, D.I.R.K. V. 2015. A late-Quaternary perspective on atmospheric p CO 2 , climate, and fire as drivers of C 4 -grass abundance. Ecology 96: 642-653.

Wang, R.Z. 2007. C4 plants in the deserts of China: occurrence of C4 photosynthesis and its morphological functional types. Photosynthetica 45: 167-171.

van der Weijde, T., Alvim Kamei, C.L., Torres, A.F., Vermerris, W., Dolstra, O., Visser, R.G., \& Trindade, L.M. 2013. The potential of C4 grasses for cellulosic biofuel production. Front Plant Sci 4: $1-18$.

Watson, L., Macfarlane, T.D. \& Dallwitz, M.J. 1992 onwards. The grass genera of the world: descriptions, illustrations, identification, and information retrieval; including synonyms, morphology, anatomy, physiology, phytochemistry, cytology, classification, pathogens, world and local distribution, and references. Version: 22nd January 2017. http://delta-intkey.com.

Winslow, J.C., Hunt, E.R., \& Piper, S.C. 2003. The influence of seasonal water availability on global C3 versus $\mathrm{C} 4$ grassland biomass and its implications for climate change research. Ecological Modelling 163: $153-173$.

Zomer, R.J., Bossio, D.A., Trabucco, A., Yuanjie, L., Gupta, D.C. \& Singh, V.P. 2007. Trees and Water: Smallholder Agroforestry on Irrigated Lands in Northern India. Colombo, Sri Lanka: International Water Management Institute. pp 45. (IWMI Research Report 122).

Zomer, R.J., Trabucco, A., Bossio, D.A., van Straaten, O., Verchot, L.V., 2008. Climate Change Mitigation: A Spatial Analysis of Global Land Suitability for Clean Development Mechanism Afforestation and Reforestation. Agric. Ecosystems and Envir. 126: 67-80. 


\title{
Chapter 5
}

\author{
Synthesis
}





\section{Key findings and implications}

\section{Sand dunes as assemblages of functional groups}

Using the functional trait approach for studying sand ecosystems revealed that this ecosystem can be defined by sets of functional groups despite their regional climatic and species pool differences. Functional groups (species with similar sets of traits) obtained by cluster analysis of the species-trait matrix gave comparable results when performed for separate climatic regions. Such repeatable patterns are crucial for global-scale application (Gitay and Noble 1997). Thus our results further support the feasibility of functional group concept across regions (Wright et al. 2004; Sasaki et al. 2011) and add a step towards generalization in biogeography and ecology. Examining functional traits instead of individual species or their composition allows the combination of the three regional datasets in one matrix. Three regions are so different in terms of species composition that it is not possible to analyze them in a meaningful way as one dataset based on the species. This is the advantage of using functional traits to study areas with no species in common.

Classification of species based on their traits, reduced the total number of species from 309 to 7 main functional groups. We found that cluster analysis is a simple but an effective method for defining functional groups. Based on our results, adaptive strategies of plants in sand dune are revealed in three groups of perennial: FG1 Non-graminoid perennials; FG2 Shrubs; FG3 Graminoid perennials; and four groups of annuals: FG4 Annual ruderals; FG5 Insect-pollinated (entomophilous) annuals; FG6 Annual (non-ruderal) grasses; FG7 Annual succulents.

Specifically, we found that plant traits in sand ecosystems are grouped reflecting habitat affiliation rather than regional belonging. Ordination analysis of the trait composition of plots shows that functional traits of the same habitat assembled together irrespective of their regions. Therefore, habitats can be described by sets of traits and functional groups reflecting the adaptive strategy of plants to the environmental conditions of that habitat. Community weighted trait means revealed the dominant traits in each sand dune habitats. For instance, insect-pollinated species with dense indumentum and thick storage stems/roots were found chiefly in stabilized dunes. In terms of functional group, ordination analysis indicated that for example perennial grasses (subgroup of FG3) and entomophilous annuals (FG5) were more associated with mobile dunes.

Observed patterns of traits and functional groups were similar across three regions and even between littoral and inland dunes. It reveals the filtering effect of habitats and supports the hypothesis that functional groups are more shaped by niche characteristic than by biogeographic regions (Cornwell et al. 2006; Lebrija-Trejos et al. 2010; Maire et al. 2012). Salinity and dryness were considered as main factors in shaping the trait assemblages and habitat characteristic. 


\section{Is habitat similarity reflected in vegetation similarity across regions?}

Habitat similarity of sand ecosystems across four climatic regions was investigated in chapter 3 to find out to what extent sand habitats are azonal with respect to taxonomic (species and genera), syntaxonomic and functional similarity.

The concept of azonality in a broader sense, refers to habitats where environmental conditions have prevailing influence on composition and structure of the vegetation over macroclimate (Mucina et al. 2006). We found by changing the focus from species to community and to functional level, sand habitats of same kind represent more similarity across regions. At the same time different sand habitats of one region have no or low similarity at all levels. It indicates that by going beyond species to the functional aspect of habitat, the vegetation becomes more independent from the regional climate and biogeography. On the other hand, the vegetation is azonal at the functional level. The lowest degree of azonality was observed at taxonomic level. Both at species and at genus level, very low similarity was found within a habitat across regions as well as across habitats within a region. It indicates that floristic composition of sand habitats highly depends on the biogeographical region.

Salt marshes and drift lines show in particular a high degree of azonality at syntaxonomic level. It is explained by particular high salinity (at least temporarily) and high disturbance rates in case of drift lines. The narrow ecological niche acts as environmental filter and thus only few tolerant species with specific adaptation to the habitat can occur and shape the communities (Gallego-Fernández \& Martínez 2011; Bermúdez \& Retuerto 2013). This explains considerable syntaxon similarities between regions as well as very low species richness recorded for these habitats, e.g. 4-6 species per plot in salt marshes. In contrast, mobile and stabilized dunes of different regions have less degree of stress and very few syntaxa in common. Therefore, the more stress-prone a habitat, the more is its vegetation habitat-related and the less dependent on the biogeographic region.

The highest similarity among habitats of the same kind but of different regions was observed at functional level. In this context, all habitats including mobile and stabilized dunes form azonal vegetation as they are independent from the climatic region. Mobile dunes of different regions are very different in plant communities and species composition; however, they show similar functional composition and physiognomy across regions and share highest proportions of graminoid perennials (FG3). They are characterized mainly by rhizomatous clonal grasses with CS/CSR strategy, pollinated and dispersed by wind. Plant communities on stabilized dunes, similarly, show common adaptation to dry conditions and thus consist of comparable functional groups across regions.

Functional aspects of the vegetation can be applied to compare plant communities across different regions. They are useful to understand and describe plant communities as they are reflecting habitat and ecosystem 
conditions. The functional approach adds a new aspect to classical phytosociology in defining high-rank syntaxa in addition to species composition and diagnostic species. Trait characters together with morphological characters of vegetation can be used to describe plant communities. We applied functional traits for defining vicariant syntaxa in sand dune habitats and to discuss their syntaxonomic position communities. For example, plant communities of Kalidietea foliaty and Salicornietea fruticosae dominated by species of similar function (FG2) and have very similar ecological needs and trait characteristics as response to similar environmental stress even though they are geographically distinct. These two ecological counterparts might even be combined into a single class.

Despite of the large area of sand deserts and coastal sands in Iran and Greece, the Phytosociological knowledge for both countries is still far from sufficient. Thus, field surveys and vegetation classification are of particular interest. Sand dune plant communities were defined and assigned to the high-rank syntaxa. Synoptic tables and the detailed syntaxonomic overview of the vegetation are provided.

\section{Sand dunes as a habitat for $\mathrm{C} 4$ plants}

By studying functional traits in sand dunes (chapter 2) we found that C4 photosynthetic type is represented in three functional groups including shrubs, graminoid perennials and annual succulents. Plant communities dominated by $\mathrm{C} 4$ plant communities were surveyed in the field. We looked at distribution of C4 plants in sand habitats of different regions are discussed (chapter 4). Improved ecological knowledge on C4 plants may be useful for understanding the global distribution pattern of C4 species. The key findings are described in the following sections.

Considerable contribution of $\mathbf{C} 4$ plants to vegetation cover $\mathrm{C} 4$ plants have notable presence in sand habitats in terms of vegetation cover despite of quite low contribution to the richness in comparison to C3 species. It indicates that environmental conditions (at least in some sand habitats) favor C4 plants, which then form dominant vegetation. Intensive light, high summer temperature and dryness are features of sand ecosystems which make $\mathrm{C} 4$ photosynthesis more efficient than the $\mathrm{C} 3$ pathway. According to crossover temperature hypothesis, at a given $\mathrm{pCO}_{2}$ and the temperature of ca. $22^{\circ} \mathrm{C}, \mathrm{C} 3$ and $\mathrm{C} 4$ plants have equal quantum yield of carbon fixation. $\mathrm{C} 4$ plants have higher quantum yield of carbon fixation at temperatures above $30^{\circ} \mathrm{C}$ in contrast to $\mathrm{C} 3$ plants which are more efficient at low temperatures (below $22^{\circ} \mathrm{C}$ ) (Ehleringer 1978; Ehleringer et al. 1997). Therefore, C4 plants in hot conditions are competitive and may dominate the area. In this respect, sand dunes of Mediterranean, Irano-Turanian and Hyrcanian regions are of particular interest as the average temperature in summer is above the crossover temperature. High vegetation cover of $\mathrm{C} 4$ plants can be explained by improved water and nitrogen use efficiency of $\mathrm{C} 4$ plants which may increase biomass allocation (Ehleringer \& Monson 1993, Long 1999). 
Chapter 5: Synthesis |

Salt marshes, mobile dunes and disturbed sandy sites as preferred habitats of $\mathbf{C 4}$ plants We found notable presence of $\mathrm{C} 4$ plants in terms of vegetation cover in mobile dunes ( $\mathrm{N}$ and $\mathrm{C}$ Iran), saltmarshes ( $\mathrm{C}$ Iran) and disturbed sandy ground (NE Greece), despite of their low number of species. There is a general trend for C4 plants to occur in hot, arid, saline and disturbed habitats (Ehleringer \& Monson 1993). Nitrogen and water use efficiency of $\mathrm{C} 4$ plants is well reflected in dry shifting dunes of $\mathrm{C}$ Iran, where dominated by diverse C4 plant communities of shrubs and grasses. Salinity stress which is also associated with drought adaptation, may have promoted the evolution of C4 halophytes (Sage 2005; Kadereit et al. 2012). Plants in disturbed habitats grow rapidly and have short life histories to withstand unfavorable conditions. In this context, the nitrogen use efficiency of $\mathrm{C} 4$ plants and the potential of high biomass production is an advantage in disturbed habitats.

We found that $\mathrm{C} 4$ abundance differed in the same habitat of different regions and common distribution patterns among habitats were not observed. Different habitat preference of $\mathrm{C} 4$ plants across regions may be partly due to climatic differences between regions and partly due to variation in $\mathrm{C} 4$ groups including different biochemical subtypes, anatomical types, monocots vs. dicots and different lineages of C4 plants. These variations are reflected in ecophysiological response to regional environmental conditions and could affect the habitat preference of different groups. For example, biomass allocation is greater in NADP-ME subtype of C4 grasses than in other subtypes and C3 species (Taylor et al. 2010); NAD-ME C4 grasses dominate drier regions (Ehleringer et al. 1997) and the total abundance of C4 monocots is correlated with temperature whereas C4 dicots with precipitation (Pyankov et al. 2010).

Higher presence of $\mathbf{C 4}$ plants in arid regions We observed a general increasing trend in richness and cover of $\mathrm{C} 4$ species with increase of aridity. The highest proportion of $\mathrm{C} 4$ species occurred in $\mathrm{C}$ Iran, the driest and warmest study region. Our result is inconsistent with effect of aridity on total abundance of C4 species in Europe (Pyankov et al. 2010).

Competitive advantage of $\mathrm{C} 4$ plants and their higher diversification in warm, dry and open environments was shown in previous studies (Long 1999) (Bouchenak-Khelladi et al. 2014). However, the current distribution of $\mathrm{C} 4$ plants in warm and dry climates is not only due to the evolution of the photosynthetic pathway but could be the heritage of their C3 ancestors and subfamilies (Taub 2000; Edwards \& Still 2008). Considering the fact that C4 plants have evolved many times independently (Christin et al. 2013; Sage 2016), it is difficult to estimate the influence of phylogenetic bias on C4 plant distribution. 


\section{General conclusions}

In conclusion, the results of this thesis show that the functional trait approach provides the possibility to generalize the ecosystem which is useful for the investigation of ecosystem properties, dynamics and functions. In this study, we objectively approached classification of functional traits through multivariate analysis. We have defined sets of functional groups applicable in different biogeographic regions with different floristic composition. We proved sand ecosystems of different regions have similar functional groups and thus sand habitats may respond in a same way to environmental drivers and disturbances. This similarity may allow a transfer of ecological findings and principles among sand ecosystems. Restoration, management and conservation actions developed in one region may thus be comprehensively applied.

As already mentioned in the key findings, results of the first two studies pointed out that functional affiliation of sand species is shaped by habitat characteristic rather than climatic regions. In the first study, sand habitats were defined as group of species with similar traits and described as sets of traits similar in one habitat. The second study compared the functional composition of the plant communities across regions. Both studies revealed that functional groups are rather independent from the regional climate and biogeography and more influenced by niche conditions. In contrast, floristic composition of sand habitats highly depends on the biogeographical region.

Sand dune habitats show a variable degree of azonality considering taxonomic, syntaxonomic and functional aspect of vegetation. The highest habitat similarity was observed at functional level, for which in this framework, all habitats are considered to belong to azonal vegetation. We found out at community level, the more stress-prone a habitat, the more is its vegetation habitat-related and independent from the region. However, species composition of habitats shows more region-related patterns. In this case, biogeographical distance prevails over environmental similarity.

The functional approach provides a new aspect to classical phytosociology as functional composition of the communities in addition to species composition can be applied to understand community ecology and to define high-rank syntaxa and vicariant communities. Description of communities based on functional traits extends the ecological aspect of the communities especially for across regions comparison in order to make syntaxonomic classification more applicable at global scale. We conclude that functional groups are an effective tool for comparison of ecosystem functions and processes and a good complementary method in classical phytosociology.

Functional trait classification also showed that in sand dune habitats assemblages of plants with C4 photosynthetic type are presented. Based on the results of the third study, salt marshes, mobile dunes and disturbed sandy grounds are specifically dominated by $\mathrm{C} 4$ vegetation and considered as preferred habitats of C4 plants. C4 plants have notable contribution to the vegetation cover in sand habitats despite of quite 
Chapter 5: Synthesis |

low contribution to the richness in comparison to $\mathrm{C} 3$ species. The patterns of $\mathrm{C} 4$ species distribution among habitats differed across regions. Phylogenetic bias and/or limited number of regions may be a reason for that. However, a generally increasing trend in richness and cover of $\mathrm{C} 4$ species with increased aridity was observed. C4 plants tend to be more tolerant in dry, saline sites under high temperature where water and nutrient availability are limiting factors for most $\mathrm{C} 3$ species.

\section{Open questions, challenges and future perspectives}

Even though in this study we showed that functional groups are an effective tool to compare ecosystems across regions with different species pool, however, the application of functional groups at global scale depends on standardized methods. This requirement has been considered in recent years and foundation works started. Nevertheless further reliable standardized attribute data need to be collected. Comprehensive trait databases for a large number of species are essential for future trait studies. Trait classification needs to be refined in order to achieve the finer assessment on response of functional groups to ecological changes. Another challenge will be to define more accurate groups which are representative of particular ecosystems, vegetation structures and plant biodiversity. Our study suggests that functional approaches are especially appropriate for ecosystems with extreme environmental conditions and distinct vegetation zonation.

There are further aspects in sand ecosystems which can be explored using functional trait approaches. They could partly be answered with the database of this thesis by further analysis and partly need a new study design and method. One analysis could reveal the influence of environmental conditions on functional groups; another could model habitat response to ecological changes when habitats are considered as units of functional groups. Open questions are for instance: 1) How do functional groups respond to environmental stress such as salinity and dryness? 2) How are environmental variables (e.g. temperature, precipitation, soil $\mathrm{pH}$ ) correlated with functional groups across different regions? 3) Which factors influence the functional diversity of sand habitats? Are they affected by climatic condition? Do they show different pattern across different regions?

The second important aspect will be to implement the functional traits and groups in conservation and management. In this context, the degree of human impact and the effect of disturbing factors on target functional groups of endangered habitats could be evaluated, to identify conservation priorities and suitable management actions. This aspect is of particular importance considering that sand dunes and salt marshes are among the most endangered and sensitive ecosystems worldwide.

Another approach is the exploration of $\mathrm{C} 4$ plant ecology and distribution patterns. Some questions were not fully answered in our study due to the limited number of study regions. For example, How do climatic parameters affect the distribution of $\mathrm{C} 4$ plants across regions? Do different subtypes of $\mathrm{C} 4$ plants 
(monocots and dicots) respond similarly to climatic conditions? Is current distribution of C4 pants in sand/saline habitats reflected in climatic conditions or habitat features? Which trait combination is used by C4 plants in disturbed habitats? To answer these questions, the study area needs to be extended to other biogeographic and climatic regions and phylogenetic analysis need to be combined with ecological analysis in order to capture the variation of $\mathrm{C} 4$ groups in response to environmental variables. It will help to better interpret and understand the notable contribution of $\mathrm{C} 4$ plants in sand vegetation which we observed in this study. 
Chapter 5: Synthesis |

\section{References}

Bermúdez, R., \& Retuerto, R. 2013. Living the difference: Alternative functional designs in five perennial herbs coexisting in a coastal dune environment. Functional Plant Biology 40: 1187-1198.

Bouchenak-Khelladi, Y., Muasya, A.M., \& Linder, H.P. 2014. A revised evolutionary history of Poales: Origins and diversification. Botanical Journal of the Linnean Society 175: 4-16.

Christin, P.-A., \& Osborne, C.P. 2014. The evolutionary ecology of C4 plants. New Phytologist 204: 765781.

Christin, P.-A., Osborne, C.P., Chatelet, D.S., Columbus, J.T., Besnard, G., Hodkinson, T.R., Garrison, L.M., Vorontsova, M.S., \& Edwards, E.J. 2013. Anatomical enablers and the evolution of C4 photosynthesis in grasses. Proceedings of the National Academy of Sciences of the United States of America 110: 1381-6.

Cornwell, W.K., Schwilk, D.W., \& Ackerly, D.D. 2006. A trait-based test for habitat filtering: convex hull volume. Ecology 87: 1465-71.

Edwards, E.J., \& Still, C.J. 2008. Climate, phylogeny and the ecological distribution of C4 grasses. Ecology Letters 11: 266-276.

Ehleringer, J.R. 1978. Implications of Quantum yield differences on the distribution of C3 and C4 grasses. Oecologia 31: 255-267.

Ehleringer, J.R., Cerling, T.E., \& Helliker, B.R. 1997. C4 photosynthesis, atmospheric $\mathrm{CO}_{2}$ and climate. Oecologia 112: 285-299.

Ehleringer, J.R., \& Monson, R.K. 1993. Evolutionary and Ecological Aspects of Photosynthetic Pathway Variation. Annual Review of Ecology and Systematics 24: 411-439.

Gallego-Fernández, J.B., \& Martínez, M.L. 2011. Environmental Filtering and Plant Functional Types on Mexican Foredunes along the Gulf of Mexico. Ecoscience 18: 52-62.

Gitay, H., Noble, I.R. 1997. What are functional types and how should we seek them? In: Smith TM, Shugart HH, Woodward FI (eds) Plant functional types: their relevance to ecosystem properties and global change. Cambridge University Press, New York.

Kadereit, G., Ackerly, D., \& Pirie, M.D. 2012. A broader model for $\mathrm{C}_{4}$ photosynthesis evolution in plants inferred from the goosefoot family (Chenopodiaceae s.s.). Proceedings. Biological sciences / The Royal Society 279: 3304-11.

Lebrija-Trejos, E., Perez-Garcia, E.A., Meave, J.A., Bongers, F., \& Poorter, L. 2010. Functional traits and environmental filtering drive community assembly in a species-rich tropical system. Ecology 91: 
386-398.

Long, S.P. 1999. Environmental responses. In: Sage, R.F., Monson, R.K., eds. C4 Plant Biology. 215-249. Toronto: Academic Press.

Maire, V., Gross, N., Börger, L., Proulx, R., Wirth, C., Pontes, L., Soussana, J.-F., \& Louault, F. 2012. Habitat filtering and niche differentiation jointly explain species relative abundance within grassland communities along fertility and disturbance gradients. New Phytologist 497-509.

Mucina, L., Rutherford, M.C., \& Powrie, L.W. 2006. Inland azonal vegetation, The vegetation of South Africa, Lesotho and Swaziland. Strelitzia 19: 617-657.

Pyankov, V.I., Ziegler, H., Akhani, H., Deigele, C., \& Lüttge, U. 2010. European plants with C4 photosynthesis: geographical and taxonomic distribution and relations to climate parameters. Botanical Journal of the Linnean Society 163: 283-304.

Sage, R.F. 2016. A portrait of the C4 photosynthetic family on the 50th anniversary of its discovery: Species number, evolutionary lineages, and Hall of Fame. Journal of Experimental Botany 67: 40394056.

Sage, R.F. 2005. Atmospheric $\mathrm{CO}_{2}$, Environmental Stress, and the Evolution of C4 Photosynthesis. In $A$ History of Atmospheric $\mathrm{CO}_{2}$ and its Effects on Plants, Animals and Ecossistems, pp. 185-213. Springer, New York.

Sasaki, T., Okubo, S., Okayasu, T., Jamsran, U., Ohkuro, T., \& Takeuchi, K. 2011. Indicator species and functional groups as predictors of proximity to ecological thresholds in Mongolian rangelands. Plant Ecology 212: 327-342.

Taub, D.R. 2000. Climate and the U.S. Distribution of C4 Grass Subfamilies and Decarboxylation Variants of C4 Photosynthesis. American journal of botany 87: 1211-1215.

Taylor, S.H., Hulme, S.P., Rees, M., Ripley, B.S., Woodward, F.I., \& Osborne, C.P. 2010. Ecophysiological traits in C3 and C4 grasses: a phylogenetically controlled screening experiment. The New phytologist 185: 780-91.

Wright, I.J., Reich, P.B., Westoby, M., Ackerly, D.D., Baruch, Z., Bongers, F., Cavender-Bares, J., Chapin, T., Cornelissen, J.H.C., Diemer, M., Flexas, J., Garnier, E., Groom, P.K., Gulias, J., Hikosaka, K., Lamont, B.B., Lee, T., Lusk, C., Midgley, J.J., Navas, M.-L., Niinemets, Ü., Oleksyn, J., Osada, N., Poorter, H., Poot, P., Prior, L., Pyankov, V.I., Roumet, C., Thomas, S.C., Tjoelker, M.G., Veneklaas, E.J., \& Villar, R. 2004. The worldwide leaf economics spectrum. Nature 428: $821-827$. 



\section{Acknowledgements}

I would like to particularly thank my supervisor Prof. Erwin Bergmeier for his helpful advises and support throughout this thesis and for giving me the opportunity to work at his department which positively influenced my scientific life. Furthermore, I would like to thank Prof. Christoph Leuschner as well as Prof. Hermann Behling, Prof. Thomas Friedl, Prof. Matthias Waltert and Prof. Holger Kreft for being part of my thesis committee and for taking the time to evaluate my work.

Sincere thanks to all my colleagues in the department of Vegetation and Phytodiversity Analysis for their help, support, discussions, their scientific and social company and all the nice times that we had together. Special thanks go to Florian Goedecke and Friedemann Goral for the nice team work experience during the monitoring project, botanical excursion and intensive fieldwork on Crete. I would like to thank Inga Schmiedel, Oliver Fried, Ricarda Pätsch and Nina Kirchhoff whom I could freely ask questions and for giving me warm responds.

I would like also to thank my parents 'Parvaneh and Farhad', my sister 'Parisa', my brother 'Nariman' and his family 'Fatemeh and Raha' as they are always there for me. Their unconditional love is a great support and gave me the strength on my way. With their help and encouragement I could finish this thesis.

Many thanks to my good friends Madina, Mandana, Rita, Waad, Roksana and Fatemeh for their company through the ups and downs of my life. Thank you for a nice feeling that you give me, when you are around. You are making my life more beautiful and colorful.

Thanks to the nature and amazing life of plants that inspired me since long. 

Appendix 



\section{Appendix A The data sheet as used for the vegetation survey}

Name(s):

\begin{tabular}{|l|l|}
\hline Relevé No. & Field No. \\
\hline Loc.: & \\
\hline & \\
\hline Relevé area: & Distance to last relevé: \\
\hline Lat.: & Alt.: \\
\hline Long.: & Slope and aspect: \\
\hline Total cov.(\%): & Soil number and depth: \\
\hline Shrub cov.(\%): & Shrub height $(\mathrm{m}):$ \\
\hline Herb cov.(\%): & Herb height $(\mathrm{cm}):$ \\
\hline Soil \& substrate type: & \\
\hline Community: & \\
\hline Note: & \\
\end{tabular}

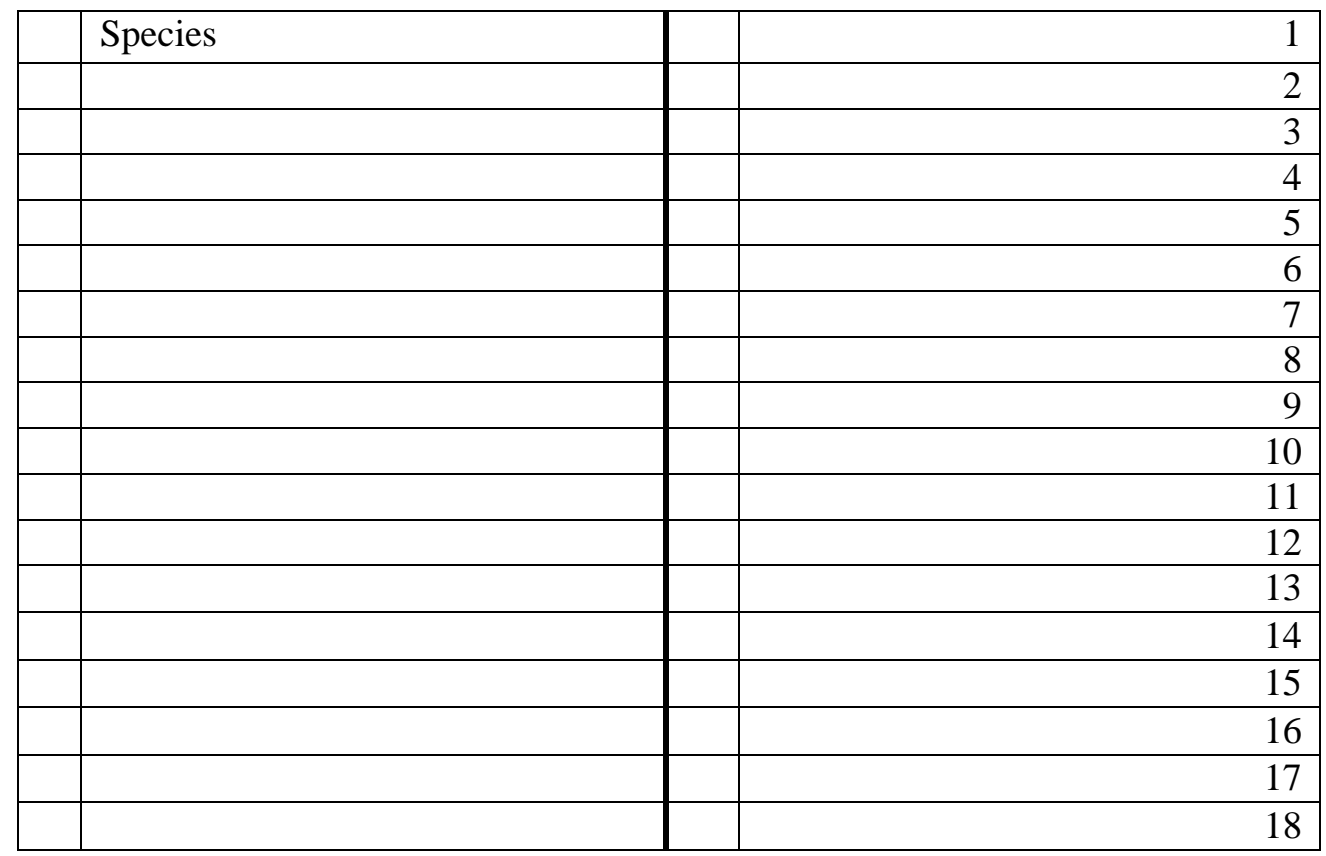

Br.-Bl. cover-abundance scale:

$\mathrm{r}=<1 \%$ [1, little plant]

$+=>1 \%[1-5$ small plants]

$1=<5 \%$ [or over 50 small plants or $1-5$ large plants]

$2=5-25 \%$

$3=25-50 \%$

$4=50-75 \%$

$5=75-100 \%$ 



\section{Appendix B Alphabetical list of species for plant functional groups resulted from cluster analysis. Plants exceptional from the general plant character composition of the groups exist in small proportions.}

\begin{tabular}{|c|c|c|}
\hline FG1 & & \\
\hline \multicolumn{3}{|l|}{ Non-graminoid perennials } \\
\hline Mediterranean & & Irano-Turanian \\
\hline Achillea maritima & Lactuca serriola & Alhagi maurorum \\
\hline Alkanna tinctoria & Limonium gmelinii & Allium kotschyi \\
\hline Allium guttatum & Lolium perenne & Artemisia sieberi \\
\hline Anchusa undulata & Lomelosia argentea & Convolvulus chondrilloides \\
\hline Artemisia campestris & Pancratium maritimum & Convolvulus dorycnium \\
\hline Artemisia santonicum & Petrorhagia illyrica & Cressa cretica \\
\hline Asperula tenella & Polygonum maritimum & Echinops sp. \\
\hline Astragalus sp. & Sarcopoterium spinosum & Frankenia hirsuta \\
\hline Calystegia soldanella & Scabiosa atropurpurea & Gymnarrhea micrantha \\
\hline Carduus sp. & Scabiosa webbiana & Heliotropium arguzioides \\
\hline Centaurea diffusa & Seseli tortuosum & Heliotropium dasycarpum \\
\hline Centaurea grisebachii & Silene frivaldszkyana & Lactuca sp. \\
\hline Chondrilla juncea & Silene otites & Peganum harmala \\
\hline Chrysopogon gryllus & Silene supina & Prosopis farcta \\
\hline Cichorium intybus & Stipa capensis & Schumannia karelinii \\
\hline Convolvulus arvensis & Teucrium capitatum & Smirnovia turkestana \\
\hline Crithmum maritimum & Thymbra capitata & \\
\hline Cynanchum acutum & Thymus sibthorpii & \\
\hline Dianthus gracilis & Trifolium physodes & \\
\hline Dianthus monadelphus & Verbascum blattaria & \\
\hline Dittrichia graveolens & Verbascum pinnatifidum & \\
\hline \multicolumn{3}{|l|}{ Dittrichia viscosa } \\
\hline Dorycnium herbaceum & Hyrcanian & \\
\hline Eryngium campestre & Alhagi maurorum & \\
\hline Eryngium maritimum & Allium subnotabile & \\
\hline Euphorbia paralias & Argusia sibirica & \\
\hline Fumana procumbens & Artemisia tschernieviana & \\
\hline Fumana scoparia & Calystegia sepium & \\
\hline Glaucium flavum & Chondrilla juncea & \\
\hline Goniolimon collinum & Convolvulus cantabrica & \\
\hline Haplophyllum suaveolens & Convolvulus persicus & \\
\hline Hypericum montbretii & Cynanchum acutum & \\
\hline \multirow[t]{2}{*}{ Hypericum olympicum } & Frankenia hirsuta & \\
\hline & Petrosimonia brachiata & \\
\hline
\end{tabular}


Appendix |

\begin{tabular}{|c|c|c|}
\hline FG2 & FG3 & \\
\hline Shrubs & Graminoid perennials & \\
\hline Mediterranean & Mediterranean & Hyrcanian \\
\hline Arthrocnemum macrostachyum & Aeluropus littoralis & Calamagrostis epigejos \\
\hline Aster tripolium & Agrostis stolonifera & Carex otrubae \\
\hline Atriplex portulacoides & Ammophila arenaria & Carex sp. \\
\hline Ephedra distachya & Bolboschoenus maritimus & Cynodon dactylon \\
\hline Halocnemum strobilaceum & Bothriochloa ischaemum & Equisetum arvense \\
\hline Osyris alba & Calamagrostis epigejos & Imperata cylindrica \\
\hline Sarcocornia fruticosa & Carex acuta & Juncus acutus \\
\hline Sarcocornia perennis & Carex divisa & Juncus heldreichianus \\
\hline Tamarix hampeana & Carex extensa & Juncus inflexus \\
\hline \multirow[t]{2}{*}{ Tamarix smyrnensis } & Cynodon dactylon & Juncus littoralis \\
\hline & Cyperus capitatus & Paspalum distichum \\
\hline Hyrcanian & Cyperus rotundus & Phragmites australis \\
\hline Ephedra procera & Elytrigia elongata & Plantago lanceolata \\
\hline Lycium shawii & Elytrigia bessarabica & Saccharum ravennae \\
\hline Punica granatum & Elytrigia juncea & Saccharum spontaneum \\
\hline \multirow[t]{2}{*}{ Rubus anatolicus } & Imperata cylindrica & Schoenus nigricans \\
\hline & Juncus acutus & Scirpoides holoschoenus \\
\hline Irano-Turanian & Juncus gerardii & \\
\hline Astragalus squarrosus & Juncus heldreichianus & Irano-Turanian \\
\hline Calligonum crinitum & Juncus littoralis & Aeluropus littoralis \\
\hline Calligonum polygonoides & Juncus maritimus & Aeluropus lagopoides \\
\hline Ephedra strobilacea & $\begin{array}{lll}\begin{array}{l}\text { Leymus } \\
\text { sabulosus }\end{array} & \text { racemosus } & \text { ssp. } \\
\end{array}$ & Centropodia forskalii \\
\hline Halothamnus subaphyllus & Melica ciliata & Cynodon dactylon \\
\hline Haloxylon ammodendron & Paspalum paspalodes & Cyperus eremicus \\
\hline Nitraria schoberi & Phragmites australis & Juncus maritimus \\
\hline Seidlitzia rosmarinus & Plantago lanceolata & Phragmites australis \\
\hline Suaeda fruticosa & Puccinellia convoluta & Stipagrostis karelinii \\
\hline Tamarix hispida & Puccinellia intermedia & Stipagrostis pennata \\
\hline \multirow[t]{8}{*}{ Zygophyllum eichwaldii } & Saccharum ravennae & Stipagrostis plumosa \\
\hline & Scirpoides holoschoenus & \\
\hline & Sorghum halepense & \\
\hline & Sporobolus pungens & \\
\hline & & \\
\hline & & \\
\hline & & \\
\hline & & \\
\hline
\end{tabular}




\begin{tabular}{|c|c|c|}
\hline FG4 & & FG5 \\
\hline Annual ruderals & & Entomophilous annuals \\
\hline Mediterranean & & Mediterranean \\
\hline Althaea sp. & Vicia lutea & Alyssum strigosum \\
\hline Amaranthus albus & Vicia villosa & Alyssum umbellatum \\
\hline Amaranthus retroflexus & Xanthium spinosum & Anthemis tomentosa \\
\hline Anthoxanthum aristatum & Xanthium strumarium & Blackstonia acuminata \\
\hline Avena sterilis & & Cakile maritima \\
\hline Bassia hirsuta & Hyrcanian & Centaurium pulchellum \\
\hline Bituminaria bituminosa & Anagallis arvensis & Centaurium spicatum \\
\hline Bupleurum tenuissimum & Astragalus tribuloides & Daucus guttatus \\
\hline Cenchrus incertus & Avena sp. & Erodium cicutarium \\
\hline Chenopodium album & Bromus danthoniae & Erysimum calycinum \\
\hline Cistus creticus & Medicago sativa & Euphorbia peplis \\
\hline Digitaria sanguinalis & Phleum paniculatum & Filago gallica \\
\hline Echinochloa crus-galli & Polypogon monspeliensis & Hedypnois rhagadioloides \\
\hline Eragrostis minor & Tragus racemosus & Helianthemum salicifolium \\
\hline Galium verum & Tribulus terrestris & Hordeum marinum \\
\hline Heliotropium europaeum & Xanthium strumarium & Hypecoum procumbens \\
\hline Herniaria hirsuta & & Jasione heldreichii \\
\hline Hibiscus trionum & Irano-Turanian & Linum trigynum \\
\hline Hordeum murinum subsp. glaucum & Centaurea bruguierana & Lotus halophilus \\
\hline Hordeum murinum subsp. murinum & Chrozophora tinctoria & Malcolmia nana \\
\hline Hypericum perforatum & Glycyrrhiza glabra & Matthiola tricuspidata \\
\hline Juncus hybridus & Haplophyllum sp. & Medicago disciformis \\
\hline Kochia laniflora & Hyoscyamus sp. & Medicago littoralis \\
\hline Malva neglecta & Polygonum luzuloides & Medicago marina \\
\hline Melilotus albus & Polypogon monspeliensis & Medicago minima \\
\hline Melilotus indicus & Sonchus oleraceus & Nigella arvensis \\
\hline Papaver dubium & Tribulus terrestris & Oenothera laciniata \\
\hline Phleum exaratum & & Onobrychis caput-galli \\
\hline Polygonum albanicum & & Portulaca oleracea \\
\hline Polygonum arenarium & & Pseudorlaya pumila \\
\hline Polypogon monspeliensis & & Sideritis montana \\
\hline Secale sylvestre & & Silene conica \\
\hline Setaria verticillata & & Silene dichotoma \\
\hline Solanum nigrum & & Silene gallica \\
\hline Sonchus asper & & Silene grisebachii \\
\hline Sonchus oleraceus & & Spergularia bocconei \\
\hline Tribulus terrestris & & Spergularia maritima \\
\hline Trifolium tomentosum & & Spergularia rubra \\
\hline Urtica dioica & & Trifolium arvense \\
\hline
\end{tabular}


Appendix |

\begin{tabular}{|c|c|c|c|}
\hline FG5 continue & FG6 & & \\
\hline Entomophilous annuals & Annual grasses & & \\
\hline Trifolium echinatum & Mediterranean & \multicolumn{2}{|l|}{ Irano-Turanian } \\
\hline Trifolium lappaceum & Apera intermedia & \multirow{2}{*}{$\begin{array}{l}\text { Bromus scoparius } \\
\text { villiglumis }\end{array}$} & \multirow[t]{2}{*}{ var. } \\
\hline Tuberaria guttata & Briza maxima & & \\
\hline \multirow[t]{2}{*}{ Xeranthemum inapertum } & Bromus diandrus & Bromus tectorum & \\
\hline & Bromus intermedius & Cornulaca aucheri & \\
\hline Hyrcanian & Bromus japonicus & Cutandia dichotoma & \\
\hline Brassica tournefortii & Bromus tectorum & Halimocnemis rarifolia & \\
\hline Cakile maritima & Corispermum nitidum & Kochia stellaris & \\
\hline Centaurium pulchellum & Corynephorus divaricatus & Salsola praecox & \\
\hline Daucus guttatus & Cynosurus elegans & Scabiosa olivieri & \\
\hline Senecio sp. & Dasypyrum villosum & Schismus barbatus & \\
\hline Silene conica & Lagurus ovatus & Tribulus longipetalus & \\
\hline Sonchus asper & Lolium rigidum ssp. rigidum & & \\
\hline Spergularia bocconei & Milium vernale & & \\
\hline \multirow[t]{2}{*}{ Spergularia diandra } & Mollugo cerviana & FG7 & \\
\hline & Parapholis filiformis & Annual succulents & \\
\hline Irano-Turanian & Plantago arenaria & Mediterranean & \\
\hline Acantholepis orientalis & Plantago coronopus & Hainardia cylindrica & \\
\hline Aphanopleura breviseta & Plantago lagopus & Petrosimonia brachiata & \\
\hline Camelina rumelica subsp. rumelica & Polypogon maritimus & Salicornia procumbens & \\
\hline Eremopyrum bonaepartis & Trifolium angustifolium & Salsola tragus & \\
\hline Erodium cicutarium & Vulpia ciliata & Salsola soda & \\
\hline Fortuynia bungei & Vulpia fasciculata & Suaeda maritima & \\
\hline Isatis minima & & Suaeda splendens & \\
\hline Koelpinia linearis & Hyrcanian & & \\
\hline Lappula sp. & Briza minor & Hyrcanian & \\
\hline Launea acanthodes & Bromus diandrus & Petrorhagia saxifraga & \\
\hline Malcolmia africana & Bromus racemosus & Salicornia iranica & \\
\hline \multirow[t]{8}{*}{ Matthiola chenopodiifolia } & Bromus tectorum & Salsola kali & \\
\hline & Corynephorus divaricatus & Suaeda crassifolia & \\
\hline & Coryspermum sp. & & \\
\hline & Cutandia memphitica & Irano-Turanian & \\
\hline & Henrardia persica var. persica & Salsola kali & \\
\hline & Parapholis incurva & Suaeda arcuata & \\
\hline & Plantago psyllium & & \\
\hline & Trisetaria linearis & & \\
\hline
\end{tabular}




\section{Appendix C List of distinguished syntaxa in the study areas}

\section{Drift lines}

Cakiletea maritimae Tx. et Preising in Tx. ex Oberdorfer 1952

Atriplicetalia littoralis Sissingh in Westhoff et al. 1946

Salsolo-Minuartion peploidis Tx. in Br.-Bl. et Tx. 1952

Cakiletum maritimae Nordhagen 1940

Atriplicion littoralis Nordhagen 1940

Atriplicetum littoralis Feekes 1936

Thero-Atriplicetalia Pignatti 1953

Euphorbion peplidis Tx. ex Oberd. 1952

Salsolo kali-Cakiletum maritimae Costa et Mansanet 1981 corr. Rivas-

Martinez, Costa \& Loidi 1992

? ? Cakile maritima-Arguzia sibirica comm.

Mobile dunes

Ammophiletea Br.-Bl. et Tx. ex Westhoff et al. 1946

Ammophiletalia Br.-Bl. et Tüxen ex Westhoff et al. 1946

Elymion arenarii Christiansen 1927

Elymo arenarii-Ammophiletum arenariae Br.-Bl. et Dee Leeuw 1936

Ammophilion Br.-Bl. 1921

Medicagini maritimae-Ammophiletum australis Br.-BI. 1921

Elymion gigantei Morariu 1957

Elymetum sabulosi Babalonas 1979

Artemisietea lerchianae Golub 1994

Artemisietalia tschernievianae Golub 1994

Euphorbion seguierianae Golub 1994

Artemisia tschernieviana comm.

\section{Stipagrostietea pennatae Zohary 1963}

Stipagrostietalia pennatae Asri 2003

Stipagrostion pennatae Asri 2003

Centropodia forsskalii comm.

Stipagrostis karelinii comm.

? Cyperus eremicus comm.

\section{Stabilized dunes}

Koelerio-Corynephoretea Klika in Klika et Novák 1941

Corynephoretalia canescentis Klika 1934

Corynephorion canescentis Klika 1931

Caricetum arenariae Christiansen 1927

Thero-Airetalia Rivas Goday 1964

Thero-Airion Tx. ex Oberdorfer 1957

Airo-Festucetum Sommer 1971

Helichryso-Crucianelletea maritimae Géhu et al. in Sissingh 1974

Crucianelletalia maritimae Sissingh 1974 
Crucianellion maritimae Rivas Goday et Rivas-Mart. 1958

Ephedro distachyae-Silenetum subconicae Oberd. 1952

Artemisietum campestris Babalonas 1979

\section{Artemisietea sieberi Zohary 1973}

Artemisietalia sieberi Zohary 1973

Artemision sieberi Asri 2003

Artemisietum sieberi Asri 2003

Prosopidion farctae Asri 2003

Prosopidetum farctae Asri 2003

Ephedrion strobilaceae Asri 2003

Ephedretum strobilaceae Asri 2003

? Stipagrostis plumosa comm.

\section{Haloxyletea ammodendri Asri 2003}

Haloxyletalia ammodendri Asri 2003

Haloxylion ammodendri Asri 2003

Haloxyletum ammodendri Zohary 1973

Calligonum crinitum comm.

\section{Salt marshes}

Thero-Salicornietea Tx. in Tx. et Oberd. 1958

Thero-Salicornietalia Pignatti 1952

Thero-Salicornion Br.-BI. 1933

Salicornia procumbens comm.

Salicornion dolichostachyo-fragilis Gehu et Rivas-Mart. in Gehu et Gehu-Franck 1984

Salicornietum strictae Christiansen ex Tx. 1974

Salicornion ramomissimae Tx. 1974

Salicornietum ramosissimae Christiansen 1955

Suaedetum maritimae (Conard 1935) Pignatti 1953

? Salicornia iranica comm.

\section{Saginetea maritimae Westhoff et al. 1962}

Frankenietalia pulverulentae Rivas-Mart. ex Castroviejo et Porta 1976

Frankenion pulverulentae Rivas-Mart. ex Castroviejo et Porta 1976

? ? Hordeum marinum comm.

? ? Psylliostachys spicata comm.

? ? Frankenia hirsuta comm.

Salicornietea fruticosae Br.-BI. et Tx. ex A. Bolòs et O. de Bolòs in A. Bolòs 1950

Salicornietalia fruticosae Br.-BI. 1933

Salicornion fruticosae Br.-Bl. 1933

Halimionetum portulacoidis Kuhnholtz-Lordat 1927

Statico bellidifoliae-Salicornietum fruticosae Br.-BI. 1933

Sarcocornio perennis-Puccinellietum convolutae J.C. Costa in Costa et al. 1997

Arthrocnemion glauci Rivas-Mart. et Costa 1984

Arthrocnemum macrostachyum comm.

Arthrocnemo glauci-Halocnemetum strobilacei Oberdorfer 1952 
Kalidietalia foliati Golub et al. 2001

Kalidion caspici Golub et al. 2001

Halocnemum strobilaceum comm.

Alhagietum pseudalhagi Asri 2003

Halostachys belangeriana comm.

Petrosimonia brachiata comm.

Seidlitzion rosmarini Asri 2003

Seidlitzietum rosmarini Asri 2003

Aeluropodetea littoralis Golub et al. 2001

Aeluropodetalia littoralis Golub et al. 2001

Aeluropodion littoralis Asri 2003

Aeluropodetum littoralis Asri 2003

Juncetea maritimi Br.-Bl. in Br.-Bl. et al. 1952

Puccinellio maritimae-Salicornietalia Br.-Bl. et De Leeuw 1936

Armerion maritimae Br.-Bl. et De Leeuw 1936

Juncetum gerardii Christiansen 1927

Festucion maritimae Christiansen 1927

Limonietum vulgaris Christiansen 1927

? Tripolium pannonicum-Salicornia iranica comm.

Juncetalia maritimi Br.-Bl. ex Horvatić 1934

Juncion maritimi Br.-Bl. ex Horvatić 1934

Juncus maritimus comm.

Phragmito-Magnocaricetea Klika in Klika et Novák 1941

Scirpetalia maritimi Hejný in Holub et al. 1967

Scirpion maritimi Dahl et Hadač 1941

Scirpetum maritimi van Langendonck 1931

\section{Festuco-Puccinellietea Soó ex Vicherek 1973}

Puccinellietalia Soó 1947

Puccinellion convolutae Micevski 1965

Aeluropus littoralis comm.

Unclassified plant communities: Ephedra procera comm., Tamarix hispida comm. 


\section{List of Publications}

Mahdavi, P. \& Bergmeier, E. Distribution of C4 plants in sand dune habitats of different region. Folia Geobotanica. Accepted.

Mahdavi, P., Isermann M. \& Bergmeier, E. 2017. Sand habitats across biogeographical regions at species, community and functional level. Phytocoenologia. Phytocoenologia, 47: 139-165.

Mahdavi, P. \& Bergmeier, E. 2016. Plant functional traits and diversity in sand dune ecosystems across different biogeographic regions. Acta Oecologica. 74: 37-45.

Akhani, H., Mahdavi, P., Noroozi, J. \& Zarrinpour, V. 2013. Vegetation patterns of the IranoTuranian steppe along a $3000 \mathrm{~m}$ altitudinal gradients in the Alborz Mountains of Northern Iran. Folia Geobotanica. 48 (2): 229-255.

Mahdavi, P. \& Akhani, H. van der Maarel, E. 2013. Species diversity and life form patterns along $3000 \mathrm{~m}$ altitudinal gradient in the steppe vegetation of southern slopes of the Alborz Mountains, Iran. Folia Geobotanica. 48 (1): 7-22.

Akhani, H., Malekmohammadi, M., Mahdavi, P. \& Chase, M. W. 2013. Phylogenetic relationship based on nrDNA ITS sequences resolves species delimitation and relationship of the Irano-Turanian lineage of the genus Limonium (Plumbaginaceae). Botanical Journal of the Linnean Society. 171: 519-550.

Akhani, H., Chatrenoor, T., Dehghani, M., Khoshravesh, R., Mahdavi, P. \& Matinzadeh, Z. 2012. A new species of Bienertia (Chenopodiaceae) from Iranian salt deserts: a third species of the genus and discovery of a fourth terrestrial $\mathrm{C}_{4}$ plant without Kranz anatomy. Plant Biosystems. 146 (3): 550-559.

\section{Conferences (selected list)}

Mahdavi, P. \& Bergmeier, E. 2015. Plant functional traits and diversity in sand dune ecosystems across different climatic regions. $24^{\text {th }}$ workshop of European Vegetation Survey (EVS). Renne, France.

Goedecke, F., Goral, F., Mahdavi, P., Dimopoulos, P., Bergmeier, E. 2015. Evaluation and threat of coastal sand dune habitats in the Natura 2000 sites of Crete (Greece). $24^{\text {th }}$ workshop EVS. Renne, France.

Mahdavi, P. \& Bergmeier, E. 2013. Comparing sand dune ecosystem in different phytogeographic regions based on plant functional types. $56^{\text {th }}$ IAVS symposium, Tartu, Estonia.

Mahdavi, P. \& Bergmeier, E. 2012. Flora and vegetation patterns and diversity in inland and littoral sand dunes of Iran. The $42^{\text {nd }}$ Annual Conference of GfÖ (Gesellschaft für Ökologie). Leuphana University, Lüneburg, Germany. 
Publications |

\section{Eigenständigkeitserklärung}

Hiermit bestätige ich die vorliegende Dissertationsschrift eigenständig verfasst und keine anderen als die im Text angegebenen Quellen und Hilfsmittel verwendet zu haben.

Ort, Datum, Unterschrift 